\title{
FONTES E MODOS DE APLICAÇÃO DE MANGANÊS NA NUTRIÇÃO, PRODUÇÃO E QUALIDADE DA SOJA, CULTIVADA EM SOLO SOB CERRADO
}

\author{
MARCELO MELARATO SILVA \\ Engenheiro Agrônomo
}

Orientador: Prof Dr. GODOFREDO CESAR VITTI

\begin{abstract}
Tese apresentada à Escola Superior de Agricultura
"Luiz de Queiroz", Universidade de São Paulo, para obtenção do título de Doutor em Agronomia, Área de Concentração: Solos e Nutrição de Plantas.
\end{abstract}

PIRACICABA

Estado de São Paulo - Brasil

Maio - 2000 


\section{Dados Internacionais de Catalogaçāo na Publicaçāo (CIP) DIVISĀO DE BIBLIOTECA E DOCUMENTAÇĀO - Campus "Luiz de Queiroz"/USP}

Silva, Marcelo Melarato

Fontes e modos de aplicação de manganês na nutrição, produção e qualidade da soja, cultivada em solo sob cerrado / Marcelo Melarato Silva. - - Piracicaba, 2000.

174 p. : il.

Tese (doutorado) - Escola Superior de Agricultura Luiz de Queiroz, 2000.

Bibliografia.

1. Diagnose foliar 2. Manejo do solo 3. Manganês 4. Nutrição vegetal 5. Produção agricola 6. Qualidade da semente 7. Química do solo 8. Soja 9. Solo de cerrado I. Título

CDD 633.34 


\section{ERRATA}

MARCELO MELARATO SILVA. Fontes e modos de aplicação de manganês na nutrição, produção e qualjdade da soja, cultjvada em solo de cerrado.

\begin{tabular}{ccccc}
\hline p. & item & linha & onde se lê & leia-se \\
\hline 10 & 2.4 & $24^{\mathrm{a}}$ & and & \& \\
148 & 4.3 .7 & $14^{\mathrm{a}}$ & menores & maiores \\
148 & 4.3 .7 & $15^{\mathrm{a}}$ & maiores & menores \\
149 & 4.3 .7 & $7^{\mathrm{a}}$ & redução & aumento \\
149 & 4.3 .7 & $8^{\mathrm{a}}$ & aumento & redução \\
155 & 4.3 .8 & $1^{\mathrm{a}}$ & Heenam \& Campbell & Heenan \& Campbell (1980) \\
163 & 6 & $3^{\mathrm{a}}$ & NORVELL & MORVELL \\
\hline
\end{tabular}


Aos meus pais, Eduardo e Yvette e aos meus irmãos, 


\section{AGRADECIMENTOS}

A Deus, pela constante presença em minha vida.

Ao Prof. Dr. Godofredo Cesar Vitti, pela amizade e orientação.

Ao Conselho Nacional de Desenvolvimento Científico e Tecnológico (CNPq), pela concessão da bolsa de estudos.

Ao Departamento de Solos e Nutrição de Plantas da Escola Superior de Agricultura "Luiz Queiroz" (USP/ESALQ), pela infra-estrutura e colaboração durante a condução desta pesquisa.

Ao Laboratório de Análise de Sementes do Departamento de Produção Vegetal da Escola Superior de Agricultura "Luiz Queiroz" (USP/ESALQ), pelo suporte para realização da avaliação da qualidade de sementes.

Ao Centro Nacional de Pesquisa de Soja (Embrapa - Soja), Londrina, PR, pela análise dos teores de óleo e proteína dos grãos.

À Agropecuária Eldorado S/A, pela cessão da área experimental na fase de campo, e às empresas Stoller do Brasil e Nutriplant, pelo fornecimento de produtos.

À Maristela Panobianco, pela valiosa contribuição e estímulo.

Ao biólogo Evandro Melarato Silva e ao acadêmico Laerte Forti Júnior, pelo apoio na execução dos experimentos. 


\section{SUMÁRIO}

Página

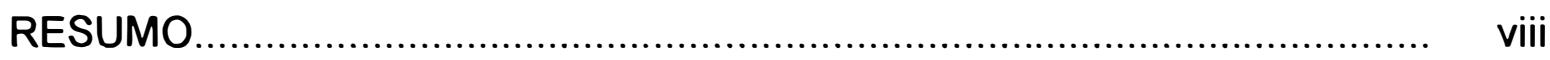

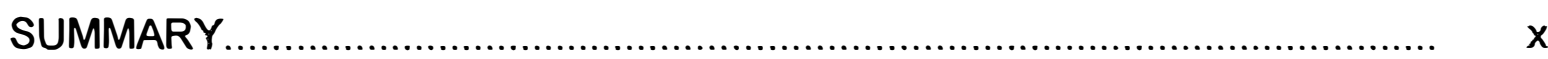

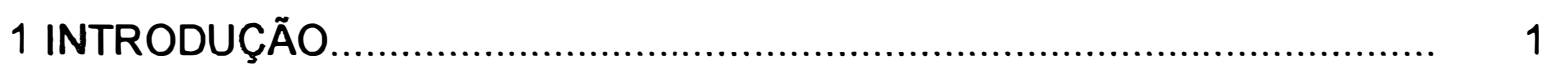

2 REVISÃO DE LITERATURA .............................................................. 3

2.1 Manganês no solo............................................................................... 3

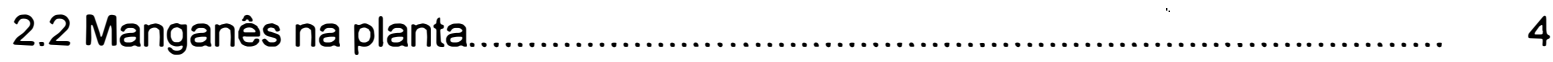

2.3 Avaliação do estado nutricional............................................................... 6

2.3.1 Diagnose visual: sintomas de deficiência e excesso de

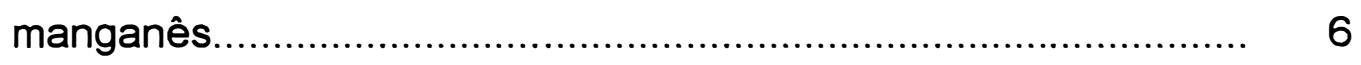

2.3.2 Análise de solo....................................................................... 7

2.3.3 Diagnose foliar........................................................................ 9

2.4 Causas da deficiência ou excesso de manganês..................................... 10

2.5 Respostas à aplicação de manganês..................................................... 13

2.6 Nutrição e qualidade de sementes....................................................... 16

2.7 Efeito da nutrição sobre os teores de proteína e óleo nos grãos............... 19

3 MATERIAL E MÉTODOS .................................................................. 21

3.1 Experimentos em casa de vegetação................................................... 21

3.1.1 Local e período de experimentação................................................. 21

3.1.2 Características e preparo do solo................................................. 21

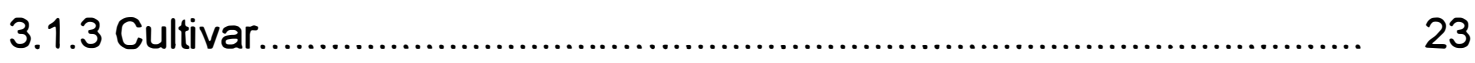

3.1.4 Instalação dos experimentos.................................................... 24

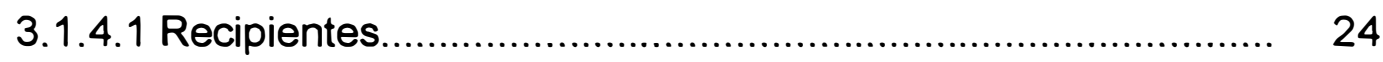

3.1.4.2 Adubação básica e enchimento dos vasos.......................... 25

3.1.4.3 Delineamento experimental............................................. 25

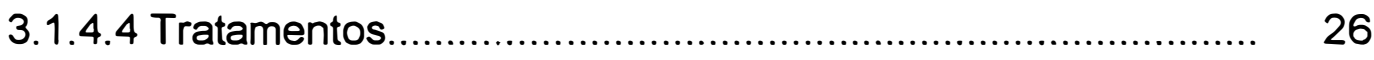

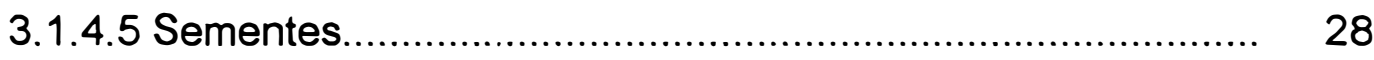

3.1.4.5.1 Análise de sementes........................................ 28

3.1.4.5.2 Tratamento de sementes.................................... 28 
3.1.5 Condução dos experimentos.

29

3.1.5.1 Aplicação dos tratamentos via solo e via semente............... 29

3.1.5.2 Semeadura .................................................................. 29

3.1.5.3 Irrigação.................................................................. 30

3.1.5.4 Desbaste........................................................... 30

3.1.5.5 Adubação em cobertura................................................. $\quad 30$

3.1.5.6 Controle de pragas....................................................... 30

3.1.5.7 Amostragem de folhas.................................................. 31

3.1.5.8 Aplicação dos tratamentos via foliar................................... 31

3.1.5.9 Coleta dos experimentos............................................... 31

3.1.6 Avaliações dos experimentos....................................................... 32

3.1.6.1 Teor de clorofila.......................................................... 32

3.1.6.2 Diagnose foliar........................................................... 33

3.1.6.3 Produção de grãos........................................................ 34

3.1.6.4 Massa de 100 grãos......................................................... 34

3.1.6.5 Massa da matéria seca................................................... 34

3.1.6.6 Índice de colheita.......................................................... 35

3.1.6.7 Análise química dos grãos............................................... 35

3.1.6.8 Análise de solo............................................................ 35

3.1.7 Procedimento estatístico.......................................................... 36

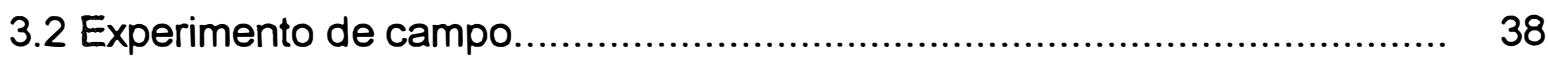

3.2.1 Local e período de experimentação............................................... 38

3.2.2 Caracterização da área experimental........................................... 38

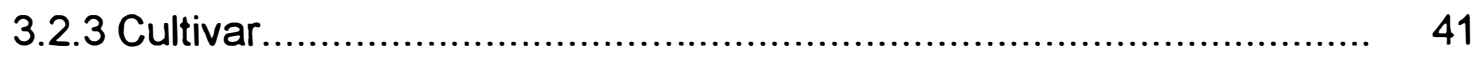

3.2.4 Instalação do experimento........................................................ 41

3.2.4.1 Preparo da área, semeadura e adubação........................... 41

3.2.4.2 Delineamento experimental............................................. 42

3.2.4.3 Tratamentos................................................................ 43

3.2.5 Condução dos experimentos ..................................................... 43

3.2.5.1 Aplicação dos tratamentos via solo.................................... 43 
3.2.5.2 Controle de pragas......................................................... 44

3.2.5.3 Amostragem de folhas................................................. 44

3.2.5.4 Aplicação dos tratamentos via foliar..................................... 44

3.2.5.5 Amostragem de solo....................................................... 45

3.2.5.6 Coleta do experimento................................................... 45

3.2.6 Avaliações do experimento...................................................... 45

3.2.6.1 Teor de clorofila............................................................. 45

3.2.6.2 Diagnose foliar........................................................... 46

3.2.6.3 Altura final de planta..................................................... 46

3.2.6.4 Produção de grãos.......................................................... 46

3.2.6.5 Análise química dos grãos............................................. 46

3.2.6.6 Análise de solo............................................................ 47

3.2.6.7 Determinação do teor de óleo e proteína............................. 47

3.2.6.8 Avaliação da qualidade das sementes................................ 47

3.2.6.8.1 Massa de mil sementes................................... 47

3.2.6.8.2 Determinação do grau de umidade...................... 48

3.2.6.8.3 Germinação..................................................... 48

3.2.6.8.4 Teste de Vigor - Envelhecimento acelerado.......... 48

3.2.6.8.5 Teste de Vigor - Condutividade elétrica................ 49

3.2.7 Procedimento estatístico.......................................................... 49

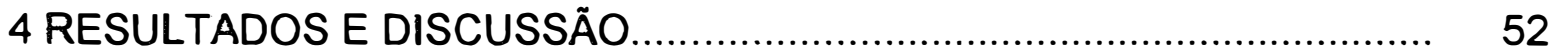

4.1 Experimento em casa de vegetação (Época 1)....................................... 52

4.1.1 Teores foliares de nutrientes................................................ 52

4.1.2 Teor de clorofila nas folhas...................................................... 63

4.1.3 Produção de grãos.................................................................. 65

4.1.4 Produção de matéria seca....................................................... 69

4.1.5 Teores de nutrientes nos grãos................................................ 69

4.1.6 Análises químicas de solo...................................................... 73

4.2 Experimento em casa de vegetação (Época 2)...................................... 77

4.2.1 Teores foliares de nutrientes..................................................... 77 
4.2.2 Teor de clorofila nas folhas .......................................................... 90

4.2.3 Produção de grãos...................................................................... 92

4.2.4 Produção de matéria seca.............................................................. 98

4.2.5 Teores de nutrientes nos grãos................................................... 100

4.2.6 Análises químicas de solo..................................................... 103

4.3 Experimento de campo................................................................... 106

4.3.1 Teores foliares de nutrientes.................................................... 106

4.3.2 Teor de clorofila nas folhas....................................................... 121

4.3.3 Altura final da planta................................................................ 125

4.3.4 Produção de grãos .................................................................. 126

4.3.5 Teores de nutrientes nos grãos............................................. 131

4.3.6 Análises químicas de solo...................................................... 137

4.3.7 Teor de óleo e proteína............................................................... 145

4.3.8 Avaliação da qualidade das sementes......................................... 150

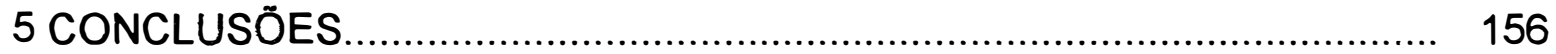

REFERÊNCIAS BIBLIOGRÁFICAS....................................................... 157 


\title{
FONTES E MODOS DE APLICAÇÃO DE MANGANÊS NA NUTRIÇÃO, PRODUÇÃO E QUALIDADE DA SOJA,CULTIVADA EM SOLO DE CERRADO
}

\author{
Autor: Marcelo Melarato Silva \\ Orientador: Prof. Dr. Godofredo Cesar Vitti
}

\section{RESUMO}

A soja é a mais importante oleaginosa cultivada no mundo e uma das principais culturas brasileiras com perspectiva crescente de competitividade no mercado externo.

Com o aumento progressivo da produtividade da cultura, resultante do uso intensivo de técnicas agrícolas, provocou-se uma retirada crescente de micronutrientes, sem que se estabelecesse adequada reposição. Além disso, em função da recomendação de calagem baseada na saturação por bases, cuja dose pode ser maior do que aquela recomendada a partir dos teores de $\mathrm{Al}, \mathrm{Ca}$ e Mg trocáveis no solo, e do sistema de plantio direto, que promove aumento da matéria orgânica e concentração do calcário na camada superficial, tem-se observado maior ocorrência de deficiência de manganês, principalmente nos solos de cerrado.

A fim de se avaliar o estado nutricional, a produção e a qualidade da soja, num Latossolo Vermelho Amarelo distrófico sob cerrado, foram realizados três experimentos, em condições de casa de vegetação (duas épocas) e de campo, utilizando-se diferentes fontes e modos de aplicação de manganês.

Foram aplicadas, via foliar, três fontes de Mn quelatizadas (cloreto, nitrato e sulfato), uma fonte mineral (sulfato) em duas doses e o fungicida 
mancozeb; via solo, foi utilizado sulfato e oxisulfato de Mn e, via semente, quelado a base de sulfato.

Com base nos resultados obtidos, pode-se concluir que: a) não foi possível corrigir-se a deficiência de manganês pela aplicação desse micronutriente via solo ou semente, nem tão pouco encontrou-se relação entre a concentração do elemento na planta com seu teor no solo; b) a aplicação de manganês via foliar em dois parcelamentos (V4 e R1) utilizando fontes quelatizadas, sais ou mesmo mancozeb, mostraram-se superiores e mais eficientes que o fornecimento do elemento via solo; $c$ ) as fontes quelatizadas foram equivalentes entre si, apresentando, quanto à dose, eficiência superior à fonte mineral e ao mancozeb; d) a leitura do teor de pigmento na folha apresentou, em condições de campo, boa correlação com os teores foliares de $\mathrm{Mn}$, indicando grande potencial para diagnose rápida do estado nutricional das plantas de soja para $\circ \mathrm{Mn}$; e) houve aumento na produção de grãos pelo fornecimento de $\mathrm{Mn}$ via foliar, assim como nas concentrações de óleo nos grãos e f) a qualidade das sementes foi influenciada positivamente pelo fornecimento de manganês. 


\title{
MANGANESE SOURCES AND APPLICATION METHODS IN THE NUTRITION, PRODUCTION AND QUALITY OF SOYBEANS CULTIVATED IN ‘CERRADO’ SOIL
}

\author{
Author: Marcelo Melarato Silva \\ Adviser: Prof. Dr. Godofredo Cesar Vitti
}

\section{SUMMARY}

Soybean is the most important oilseed plant cultivated in the world and one of the major Brazilian crops with a growing perspective of competitiveness in the external market.

With the progressing increase of the yield of the culture as a result of intensive use of agricultural techniques, an increasing removal of micronutrients was provoked while no adequate replacement was provided. In addition, on account of the recommended liming with soil base saturation, which dose can be higher than that recommended with the contents of soil-exchangeable $\mathrm{Al}, \mathrm{Ca}$ and $\mathrm{Mg}$, and of the direct planting system, which promotes the increase of the organic matter and limestone concentration at the top layer, one has observed an increased occurrence of manganese deficiency, mainly in 'cerrado' soils.

In order to evaluate the nutritional state, the production and the quality of soybeans in a dystrophic Red-Yellow latosol three experiments were conducted in a greenhouse (two seasons) and in the field using different manganese sources and application methods.

Via leaf, one applied Mn chelate sources (chloride, nitrate and sulfate), one mineral source (sulfate) in two applications and fungicide mancozeb; via soil one used sulfate and Mn oxysulfate and via seed, sulfate-based chelate. 
The results showed that: a) the manganese deficiency amendment was not possible by applying such micronutrient via soil or seed, and no relationship was found between the concentration of the element in the plant and its content in the soil; b) the application of manganese via leaf in two split applications (V4 and R1) using chelate sources, salts or even mancozeb was superior and more efficient than the element's supply via soil; c) the chelate sources were equivalent among themselves, and, as to the dose, had a superior efficiency than the mineral source and mancozeb; d) the reading of the pigment content in the leaf at field conditions had a good correlation with the leaf contents of $\mathrm{Mn}$ thus indicating a great potential for a rapid diagnosis of the nutritional state of soybean plants for $\mathrm{Mn}$; e) there was an increase in the production of grains by supplying Mn via leaf, as well as in the concentrations of oil in the grains; and f) the seed quality was positively influenced by the manganese supply. 


\section{INTRODUÇÃO}

A soja é a mais importante oleaginosa cultivada no mundo e uma das principais culturas brasileiras com perspectiva crescente de competitividade em relação aos seus principais concorrentes, Estados Unidos e Argentina (Barbosa et al., 1999). O Brasil se destaca, entretanto, pelo maior potencial agrícola em relação a expansão da economia do complexo soja (grão, óleo e farelo), que atualmente é líder das exportações brasileiras, tanto pela possibilidade de aumento da área produzida (crescimento horizontal) quanto pelo aumento de produtividade (crescimento vertical). A produção brasileira é de aproximadamente 30 milhões de toneladas numa área cultivada em torno de 11 milhões de hectares.

Atualmente, o Brasil, pode ser considerado o maior exportador de farelo desta oleaginosa, responsável por $28,5 \%$ do volume total transacionado no mundo e ocupa o segundo lugar nas exportações de grãos $(22,8 \%)$ e de óleo (19,8\%) (Barbosa et al., 1999).

O Brasil possui ainda cerca de 300 milhões de hectares de áreas com potencial agrícola. Destes, cerca de 200 milhões de hectares estão sob cerrado, onde as condições climáticas são adequadas para o cultivo da soja. Apenas cerca de 20 milhões são cultivados com grãos, sendo apenas 1/3 ocupados pela soja. Pode-se inferir, portanto, que há um potencial nessa nova fronteira de 180 milhões de hectares para serem explorados por grãos (Leite, 1999).

Dentre os problemas encontrados no início do cultivo da soja, nos cerrados, podem ser destacados a baixa fertilidade natural, $\circ$ baixo $\mathrm{pH}$ e $\circ$ excessivo teor de manganês e alumínio na maioria dos solos. Com o aumento 
progressivo da produtividade da cultura, resultante do uso intensivo de técnicas agrícolas, provocou-se uma retirada crescente de micronutrientes, sem que se estabelecesse adequada reposição.

Em média são exportados $28 \mathrm{~g}$ de boro, $20 \mathrm{~g}$ de cobre, $149 \mathrm{~g}$ de ferro, $32 \mathrm{~g}$ de manganês e $64 \mathrm{~g}$ de zinco por tonelada de grãos de soja produzidos (Santos et al., 1986). Estes valores variam de acordo com os teores disponíveis em cada solo, com as condições do ambiente e com a capacidade de extração de cada cultivar. Sendo as reservas dos solos limitadas, principalmente nos latossolos sob cerrado, a retirada contínua, sem a correta reposição, pode determinar o aparecimento de carências que reduzem a produtividade da cultura (Santos, 1999).

Por outro lado, em função da recomendação de calagem baseada na saturação por bases, cuja dose pode ser maior, principalmente nos solos argilosos, do que aquela recomendada a partir dos teores de $\mathrm{Al}, \mathrm{Ca}$ e $\mathrm{Mg}$ trocáveis no solo, e do sistema de plantio direto, que promove aumento da matéria orgânica e a concentração de calcário na camada superficial, tem-se observado, a exemplo do que vêm ocorrendo com outros micronutrientes, aumento na deficiência de manganês (Novais et al, 1989; Tanaka et al, 1989; Tanaka et al, 1992; Abreu et al., 1996).

Com base na literatura, pode-se dizer que há pouca informação à respeito do comportamento das fontes de manganês e da forma de aplicá-las nos solos sob cerrado, principalmente no sistema de plantio direto, onde as condições podem não ser favoráveis ao aproveitamento, pela planta, do manganês presente no solo. Nesse caso, a aplicação do elemento via foliar pode ser mais eficiente.

Assim, a presente pesquisa teve por objetivo avaliar 0 estado nutricional, a produção e a qualidade da soja, tratada com diferentes fontes e modos de aplicação de manganês, num solo sob cerrado, em condições de casa de vegetação e de campo. 


\section{REVISÃO DE LITERATURA}

\subsection{Manganês no solo}

No solo, o manganês pode estar presente na estrutura dos minerais, organicamente complexado, trocável e na solução do solo. As reações químicas deste elemento no solo são complexas devido, principalmente, aos três estados de oxidação envolvidos: $\mathrm{Mn}^{2+}$ (o mais comum), $\mathrm{Mn}^{3+}$ e $\mathrm{Mn}^{4+}$, formando óxidos hidratados com diferentes estados de valência.

$\mathrm{Na}$ estrutura de minerais a forma de óxidos de manganês é a mais encontrada no solo, sendo a pirolusita $\left(\mathrm{MnO}_{2} \cdot \mathrm{nH}_{2} \mathrm{O}\right) \circ$ mineral de manganês mais estável sob condições oxidadas. Além do potencial redox, $\circ \mathrm{pH}$ e a pressão de $\mathrm{CO}_{2}$ comandam também o equilibrio entre as formas de manganês no solo. Os minerais $\mathrm{Mn}_{2} \mathrm{O}_{3} \cdot \mathrm{nH}_{2} \mathrm{O}$ (bixbyita), $\mathrm{Mn}_{3} \mathrm{O}_{4} \cdot \mathrm{nH}_{2} \mathrm{O}$ (haussmanita) e $\mathrm{Mn}(\mathrm{OH})_{2}$ (pirocroíta) não são estáveis na maioria dos solos agrícolas, uma vez que a pressão de gás carbônico $\left(\mathrm{CO}_{2}\right.$ gás) dificilmente cai abaixo daquela normal do ar $\left(10^{3,52} \mathrm{~atm}\right)$. As formas de sulfato sólido cristalino $\mathrm{MnSO}_{4}$, $\mathrm{MnSO}_{4} \cdot \mathrm{H}_{2} \mathrm{O}$ e $\mathrm{Mn}_{2}\left(\mathrm{SO}_{4}\right)_{2}$ são também muito solúveis para precipitar nas condições normais de redox e de concentrações de sulfato encontradas na natureza e, por isso, sulfatos de manganês dificilmente serão encontrados no solo (Lindsay, 1979 e Borkert, 1991).

O manganês bivalente pode formar complexos com compostos orgânicos do solo, que podem ser solúveis ou insolúveis. Em condições naturais, a concentração do ligante orgânico é mantida pela atividade biológica, 
sendo que os tratamentos químicos ou físicos do solo afetam a atividade microbiana, diminuindo a produção de ligante orgânico e alterando a solubilidade do Mn no solo (Miyazawa et al., 1993). Estes autores concluíram que a complexação orgânica é, provavelmente, o principal mecanismo que controla a solubilidade do manganês no solo.

O Mn trocável encontra-se, principalmente, na forma de íon divalente $\left(\mathrm{Mn}^{2+}\right)$ e está ligado às cargas eletro-negativas nos colóides minerais e orgânicos do solo (sítios de troca de cátions). Um amplo limite de valores de $\mathrm{Mn}$ trocável pode ser encontrado no solo (Borkert, 1991): os solos muito ácidos apresentam teores superiores a $1000 \mathrm{mg} \mathrm{dm}^{3}$, enquanto que os solos orgânicos, com reação próxima da neutralidade, apresentam teores inferiores a $0,1 \mathrm{mg} \mathrm{dm}^{-3}$. A solução extratora usada na determinação do elemento no solo pode levar a variações na quantidade de Mn trocável.

$\mathrm{Na}$ solução do solo, o manganês pode apresentar-se tanto na forma iônica $\left(\mathrm{Mn}^{2+}\right)$ quanto combinado a compostos orgânicos solúveis. Além disso, pode formar íons simples e complexos na solução do solo, bem como diversos óxidos de composição variável. As condições de $\mathrm{pH}$ e o potencial redox mantêm e controlam a atividade das formas iônicas na solução do solo (Lindsay, 1979). Nas condições redox encontradas em solos bem drenados, a espécie $\mathrm{Mn}^{2+}$ é a mais abundante, enquanto que as espécies resultantes de hidrólise do manganês, $\mathrm{Mn}(\mathrm{OH})^{+}$e $\mathrm{Mn}(\mathrm{OH})_{2}$, são de menor importância (Camargo, 1991).

\subsection{Manganês na planta}

As necessidades de manganês das plantas são supridas pelo elemento presente na solução do solo que pode estar na forma iônica $\left(\mathrm{Mn}^{2+}\right)$ ou organicamente complexado. O suprimento às raizes é efetuado por fluxo de massa e por difusão (Borkert, 1991). 
O sistema radicular das dicotiledôneas apresenta maior capacidade de troca de cátions em comparação às monocotiledôneas; consequentemente, esta maior absorção resulta em uma redução do pH da rizosfera (Ray \& Diest, 1979). Na cultura da soja, foi observado por Souza (1996) aumento de micronutrientes, dentre eles o manganês, na parte aérea da planta em função da acidificação da rizosfera.

O manganês é absorvido pela planta na forma de $\mathrm{Mn}^{2+}$ e transportado no xilema na forma iônica, em razão da pouca estabilidade dos seus quelados. A sua mobilidade na planta é considerada intermediária (Mengel \& Kirkby, 1987; Tanaka et al., 1993).

Kabata-Pendias \& Pendias (1985) relataram uma concentração menor de manganês em exsudato do floema do que em tecidos das folhas, concluindo que o pequeno transporte do elemento através do floema é responsável pela sua baixa concentração em frutos, sementes e órgãos de reserva das raízes.

As funçōes do manganês lembram as do magnésio. $O$ manganês é ativador de muitas enzimas, como descarboxilases, hidrolases e transferidoras de grupos (fosfoquinases e fosfotransferases). Participa da reação de fotólise da água e na evolução do $\mathrm{O}_{2}$ no sistema fotossintético (equação de Hill), da formação de clorofila e da formação, multiplicação e funcionamento dos cloroplastos (Malavolta, 1976; Sfredo \& Panizzi, 1990; Dechen et al., 1991a; Tanaka et al., 1993).

O manganês também atua no metabolismo do nitrogênio (particularmente na redução seqüencial do nitrato), nos compostos cíclicos como precursor de aminoácidos aromáticos, hormônios (auxinas), fenóis e ligninas (Heenan \& Campbell, 1980). Como composto, o manganês é encontrado na manganina, uma proteína existente nos vegetais. 


\subsection{Avaliação do estado nutricional}

\subsubsection{Diagnose visual: sintomas de deficiência e excesso de manganês}

A diagnose visual permite uma avaliação qualitativa do estado nutricional das plantas através de sintomas que se traduzem por um conjunto de anomalias que são comuns para o elemento em questão.

A soja é uma planta sensível tanto à deficiência quanto à toxicidade de manganês.

O sintoma de deficiência de manganês caracteriza-se por um mosqueado variando de verde claro a amarelo entre as nervuras das folhas (Quaggio et al., 1991), sendo que este sintoma pode evoluir para uma clorose internerval (Vernetti, 1983). Esta clorose apresenta-se como um reticulado formado pelas nervuras (que permanecem verdes) semelhante ao da deficiência de ferro, porém, mais grosseiro (Malavolta, 1980).

Conforme já mencionado, o Mn é considerado, de modo geral, elemento de baixa mobilidade no floema; portanto, os sintomas de deficiência tendem a aparecer nos tecidos mais jovens (folhas novas). Não obstante, Ohki et al. (1979) verificaram translocação do $\mathrm{Mn}$ de tecidos velhos para os novos, em plantas de soja, resultando em sintomas de clorose internerval também nas folhas inferiores. Novais et al. (1989) atribuíram este sintoma, que poderia ser confundido com deficiência de magnésio, à baixa disponibilidade de manganês para a planta ocorrida em valores de $\mathrm{pH}$ na ordem de 6,7.

Segundo Parker et al. (1969), os sintomas de toxicidade de manganês na soja podem ser descritos como enrugamento das folhas, clorose internerval, pontos necróticos no limbo foliar e má formação das vagens, resultando em maior número de vagens com uma semente. Mengel (1987) e Malavolta et al. (1997) caracterizaram os sintomas de toxicidade na soja pelo aparecimento de folhas com pontuações pardas que coalescem, ao longo das nervuras, encarquilhadas e depois amareladas. Malavolta \& Klieman (1985) observaram 
que a clorose internerval assemelha-se, inicialmente, àquela provocada pela deficiência de magnésio.

\subsubsection{Análise de solo}

A análise do solo constitui ferramenta eficiente para avaliar a fertilidade do solo. No caso de micronutrientes, embora oferecendo perspectivas promissoras, a análise de solo teve até hoje uso bastante restrito. O interesse, no entanto, de técnicos e produtores pela análise de micronutrientes em solos tem aumentado a cada ano, principalmente pelo aparecimento de deficiências desses nutrientes na maioria das culturas (Abreu et al, 1997).

Estes autores ressaltaram ainda que, no caso do $\mathrm{Mn}$ e Fe, a análise de solo tem sua complexidade aumentada, pois a disponibilidade destes elementos é grandemente influenciada pelas reações de oxi-redução do solo. Apesar dos coeficientes de correlação entre metal-solo e metal-planta serem baixos, os resultados de pesquisa são promissores, pois mostram a viabilidade da análise do solo como critério diagnóstico para avaliar a disponibilidade de Mn às plantas.

Para uma nutrição adequada, Tisdale et al. (1985) consideraram teores no solo de 2,0-3,0 mg dm $\mathrm{mg}^{3}$ de manganês solúvel em água.; 0,2 - 5,0 mg $\mathrm{dm}^{-3}$ de manganês trocável e $25-65 \mathrm{mg} \mathrm{dm}^{-3}$ de manganês facilmente redutível.

É importante ressaltar que sempre que forem referidos teores de manganês solúvel ou trocável no solo, deve ser feita menção ao extrator utilizado. Caso contrário, qualquer comparação a ser feita com teores encontrados em outras pesquisas torna-se sem consistência (Borkert, 1991).

Abreu et al. (1996) concluiram que o extrator DTPA 7,3 foi mais eficiente em relação ao Mehlich-1 para avaliação da disponibilidade de Mn às plantas em solos que receberam adubação com esse elemento. A capacidade 
do DTPA 7,3 em diferenciar fontes e doses de fertilizantes contendo $\mathrm{Mn}$ foi importante, uma vez que a concentração deste elemento na planta de soja (característica usada para avaliar a disponibilidade de $\mathrm{Mn}$ no solo) sofreu efeito interativo das fontes e doses de Mn.

Rosolem et al. (1992), analisando a relação entre Mn extraído do solo e a concentração deste elemento em plantas de soja, observaram que o desempenho do DTPA $(r=0,72)$ foi ligeiramente superior ao do Mehlich-1 $(r=0,68)$ quando os niveis de $\mathrm{Mn}$ no solo foram modificados pela adição de sulfato de Mn. Abreu et al. (1994) obtiveram resultados semelhantes, aplicando doses crescentes de cloreto de Mn (p.a.) em dez amostras de solo do Estado de São Paulo. Os coeficientes de correlação encontrados entre Mn-plantas de soja e Mn-solo foram de 0,78 (quando utilizaram o DTPA) e de 0,71 (para o Mehlich-1). Assim, para o Estado de São Paulo usando-se DTPA 7,3 como extrator, Raij et al. (1996) consideraram para Mn, respectivamente, como limites de teores baixo, médio e alto, expressos em $\mathrm{mg} \mathrm{dm}^{-3}$, os seguintes: 0-1,2; 1,35,0 e $>5,0$.

A região dos cerrados, no Brasil Central, tem mostrado respostas mais acentuadas ao uso de micronutrientes, dentre eles o manganês. Entretanto, trabalhos de campo específicos para avaliação de niveis críticos somente receberam atenção da pesquisa recentemente, sendo que o enfoque no passado foi mais em termos de avaliação de repostas a doses de micronutrientes (Abreu et al., 1997; Fontes, 1997).

Lopes \& Guilherme (1994) estabeleceram limites de interpretação para solos sob cerrado, utilizando Mehlich - 1 como extrator, sendo que para $\mathrm{Mn}$ consideraram como limites de teores baixo, médio e alto, expressos em $\mathrm{mg} \mathrm{dm}^{-3}$, para pH $\left(\mathrm{em} \mathrm{H}_{2} \mathrm{O}\right)$ do solo de 6 e 5, os seguintes: $<5$ e $<2 ; 5-15$ e 2-6; >15 e >6, respectivamente. 


\subsubsection{Diagnose foliar}

A diagnose foliar é um método de avaliação do estado nutricional das culturas em que se analisam determinadas folhas em períodos definidos da vida da planta. As folhas são escolhidas para a análise em razão de serem órgãos que, como regra geral, refletem melhor o estado nutricional, isto é, respondem mais às variações no suprimento de nutrientes, seja pelo solo, seja pelo fertilizante (Malavolta et al., 1997).

Devido à redistribuição de nutrientes através de diversos órgãos da planta em diferentes estádios do ciclo estabeleceu-se que a amostragem de folhas de soja, para análise química, deve ser efetuada na época de pleno florescimento, coletando-se folhas recém maduras com peciolo, que correspondem a terceira elou quarta a partir do ápice da haste principal. $\mathrm{Na}$ necessidade de se amostrar folhas fora do período recomendado, sugere-se que sejam coletadas folhas de plantas normais que servirão para comparação com folhas de plantas problemas (Tanaka et al., 1993; Ambrosano et al., 1996).

Baseando-se nos padrões de amostragem descritos, são considerados como adequados, na matéria seca de folhas de soja, os teores de 40 a $54 \mathrm{~g} \mathrm{~kg}^{-1}$ para nitrogênio; 2,5 a $5,0 \mathrm{~g} \mathrm{~kg}^{-1}$ para fósforo; 17 a $25 \mathrm{~g} \mathrm{~kg}^{-1}$ para potássio; 4 a $20 \mathrm{~g} \mathrm{~kg}^{-1}$ para cálcio; 3 a $10 \mathrm{~g} \mathrm{~kg}^{-1}$ para magnésio; 2,1 a $4,0 \mathrm{~g} \mathrm{~kg}^{-1}$ para enxofre; 21 a $55 \mathrm{mg} \mathrm{kg}^{-1}$ para boro; 10 a $30 \mathrm{mg} \mathrm{kg}^{-1}$ para cobre; 50 a 350 $\mathrm{mg} \mathrm{kg}{ }^{-1}$ para ferro; 20 a $100 \mathrm{mg} \mathrm{kg}^{-1}$ para manganês; 1,0 a $5,0 \mathrm{mg} \mathrm{kg}^{-1}$ para molibdênio e 20 a $50 \mathrm{mg} \mathrm{kg}^{-1}$ para zinco (Ambrosano et al., 1996; Malavolta et al., 1997 e Embrapa, 1998).

Ohki et al. (1977), correlacionaram niveis foliares de manganês em folhas recém maduras e produção de grãos de soja em diversas fases da cultura. O nivel crítico de $\mathrm{Mn}$ foi, respectivamente, de 7 a $10 \mathrm{mg} \mathrm{kg}^{-1}$ nas folhas amostradas de 4-9 semanas após o plantio e de 20 e $22 \mathrm{mg} \mathrm{kg}^{-1}$ nas amostradas 12 e 16 semanas do plantio. Estes autores concluíram que a 
amostragem feita 9 semanas após o plantio representam melhor o 'status' de manganês na planta em condições de campo.

Tanaka et al. (1992) constataram, através de análises químicas de folhas, em solos com diferentes pH e saturação por bases, deficiência de manganês em soja, cv. Garimpo, em Uberlândia (MG). Nas plantas deficientes, o teor de manganês nas folhas era de $13 \mathrm{mg} \mathrm{kg}^{-1}$, abaixo portanto do nível crítico de $20 \mathrm{mg} \mathrm{kg}^{-1}$, enquanto que as plantas normais apresentaram teores de $31 \mathrm{mg} \mathrm{kg}^{-1}$.

\subsection{Causas da deficiência ou excesso de manganês}

Como visto anteriormente, o nível de Mn divalente no solo depende das reações de oxi-redução. Assim, todos os fatores que as afetem têm importância na disponibilidade desse nutriente.

Os microrganismos são responsáveis por muitas das reações de redução e oxidação que ocorrem no solo. A decomposição da matéria orgânica pela biomassa heterotrófica pode resultar em liberação de compostos orgânicos que podem formar outros complexos solúveis com metais, tais como cobre, ferro, manganês e zinco. Esta ação solubilizadora também pode ocorrer pelos exsudados das raízes (Godo \& Reisenauer, 1980; Tanaka et al.,1993). Esses complexos orgânicos solúveis (quelados) aumentam significativamente a solubilidade daqueles metais. Por outro lado, a formação de complexos estáveis com a matéria orgânica do solo pode diminuir a disponibilidade dos mesmos (Borkert, 1991).

Experimentos em solução nutritiva, mostraram que a adição de silício no meio melhorou a distribuição de Mn em plantas de cevada (Willians and Vlamis, 1957).

A deficiência de manganês em uma planta pode ocorrer quando a velocidade de absorção do nutriente é insatisfatória diante da velocidade de 
crescimento da planta e/ou quando esta apresenta aumento da demanda funcional desse elemento. A demanda funcional pode ser definida como a concentração mínima de um nutriente na planta capaz de manter suas funções metabólicas (Ghazali \& Cox, 1981).

Períodos de seca prolongados (aumento da aeração e oxidação do $\mathrm{Mn}^{2+}$ ) ou de baixas temperaturas, associados a condições de solos arenosos e bem drenados, pobres em $\mathrm{Mn}$ total, favorecem a deficiência de manganês (Malavolta, 1980). A baixa intensidade luminosa afeta a absorção do elemento pelas plantas, podendo também levar a uma situação de deficiência (Marinho, 1988). Doses altas de fósforo poderão causar deficiência de manganês. Neste caso, o uso de micronutriente fica obrigatório (Malavolta et al., 1991).

Muitos trabalhos relacionaram o efeito da calagem e aumento de $\mathrm{pH}$ com deficiência de manganês. A correção de acidez do solo provoca maior atividade microbiana podendo levar à complexação do $\mathrm{Mn}$, tornando-o meno, disponível. A calagem também reduz a absorção de manganês por diminuir a sua solubilidade na solução do solo. $O$ aparecimento de deficiência desse nutriente é, portanto, favorecido pelo pH elevado (Ritchey et al., 1981; Novais et al., 1989).

Nos EUA, a deficiência de Mn tem sido observada na cultura da soja em solos com pH alto, levando vários autores a estudar o assunto, dentre os quais pode-se citar: Randall et al. (1975a, b), Parker et al. (1981), Reddy et al. (1987), entre outros.

A deficiência de manganês em soja tem sido constatada em solos sób cerrado e em solos da região sul do Brasil, especialmente quando se eleva o pH a valores próximos da neutralidade (Santos, 1999).

Estudos desenvolvidos por Quaggio et al. (1982) abordando os efeitos da calagem sobre a concentração de $\mathrm{Mn}$ nas folhas de soja revelaram teores foliares inversamente proporcionais às doses de calcário aplicadas.

Tanaka et al. (1992) relataram deficiência de manganês em soja cv. Garimpo pela aplicação de doses excessivas de calcário ( $81 \%$ de saturação por 
bases e 5,9 de pH em $\mathrm{CaCl}_{2}$ ). $\mathrm{O}$ mesmo efeito foi observado em conseqüência da incorporação superficial do calcário (Tanaka et al.,1989). Neste último caso, o maior desenvolvimento do sistema radicular das plantas pode possibilitar a absorção de manganês disponível nas camadas mais profundas do solo (fora do efeito da calagem), corrigindo a deficiência.

A presença de outros cátions na solução do solo pode interferir na disponibilidade de $\mathrm{Mn}$ às plantas levando a sua deficiência. Nesse sentido, doses elevadas de potássio pode levar a esta indução (Rosolem \& Nakagawa, 1986). Malavolta et al. (1997) destacaram que o manganês possui propriedades químicas semelhantes a de metais alcalino-ferrosos, como cálcio e magnésio, podendo estes cátions inibir a sua absorção e transporte. Solos ricos em ferro, cobre elou zinco, mesmo que temporariamente, podem também induzir à deficiência de Mn na soja (Marinho, 1988; Vitti \& Luz, 1998).

Outro fator relacionado à deficiência de $\mathrm{Mn}$ é a própria planta, uma vez que diferentes espécies e/ou cultivares podem diferir na composição mineral, embora se desenvolvendo em condiçōes semelhantes. A capacidade das plantas excretarem ácidos orgânicos, reduzindo o $\mathrm{Mn}^{+4}$ a $\mathrm{Mn}^{+2}$ na rizosfera, pode influenciar no estado nutricional de Mn (Vitti \& Luz, 1998). Nesse sentido, Abreu et al. (1994) trabalhando com 12 cultivares de soja encontraram diferenças de suscetibilidade à deficiência de $\mathrm{Mn}$, através de avaliação da produção de matéria seca; dentre os cultivares estudados, o Garimpo foi considerado um dos mais sensiveis a deficiência de manganês.

Assim, com a finalidade de identificar cultivares de soja sensiveis e tolerantes à deficiência de manganês, Mascarenhas et al. (1990a) observaram que a aplicação de $2 \mathrm{mg} \mathrm{L}^{-1}$ de manganês resultaram em diferentes níveis de sintomas de deficiência, dentre os cultivares estudados.

Oliveira et al. (1997) utilizando-se quinze cultivares de soja, em três níveis de $\mathrm{pH}(5,6 ; 6,6$ e 7,1$)$, verificaram comportamentos distintos entre os cultivares em relação a sintomas visuais de deficiência de manganês. 
Em condições de campo, a toxicidade de manganês em plantas ocorre em solos ácidos, geralmente associada à de alumínio. A toxicidade de ambos é um dos fatores limitantes mais importantes ao crescimento em solos de regiões tropicais e subtropicais onde a toxicidade de manganês é muito mais freqüente do que a própria deficiência (Dechen et al., 1991b). Em solos ácidos, a maior solubilidade dos compostos de manganês favorece a toxicidade deste elemento (Tanaka et al., 1993).

Condições de má drenagem, compactação, inundação prolongada ou qualquer outro fator que leve à deficiência de aeração do solo, propicia a predominância da reação de redução, resultando na formação de manganês livre $\left(\mathrm{Mn}^{2+}\right)$.

O uso contínuo de doses altas de adubos nitrogenados fisiologicamente ácidos (sulfato de amônio, uréia, nitrato de amônio, fosfato de amônio), adubações elevadas que forneçam cátions capazes de deslocar o $\mathrm{Mn}^{2+}$ do complexo de troca para a solução do solo e o acúmulo no solo de defensivos contendo manganês favorecem, também, o aparecimento de toxicidade de manganês (Marinho, 1998). Segundo Mengel et al. (1987), a toxicidade de manganês está freqüentemente associada a baixos teores de cálcio e ferro nos tecidos vegetais.

Baseado no exposto, existem diversos fatores que podem levar tanto à deficiência quanto à toxicidade de manganês. Na maioria dos casos, pode-se dizer que estão relacionados direta ou indiretamente às reações do solo e às práticas culturais.

\subsection{Respostas à aplicação de manganês}

A eficiência agronômica das fontes de manganês está intimamente associada à via de aplicação. Quando fornecido ao solo, o manganês divalente 
é facilmente oxidado para formas não disponíveis em solos neutros ou calcários (Lopes, 1991).

A aplicação ao solo de fertilizantes contendo manganês é uma maneira comum de corrigir a deficiência desse elemento para a cultura da soja, embora a eficiência agronômica dos adubos contendo esse nutriente ainda não seja bem conhecida (Abreu et al., 1996).

Pesquisa conduzida por Randall et al. (1975b) indicou que foram necessárias aplicações de manganês da ordem de 5 a $11 \mathrm{~kg}$ por hectare do elemento, como $\mathrm{MnSO}_{4}$ na adubação inicial, em áreas onde as plantas exibiram sintomas severos de deficiência de Mn.

Estudo realizado com plantas de soja em condições de casa de vegetação, utilizando Latossolo sob cerrado, demonstrou resposta a aplicação de doses crescentes de manganês ao solo (Abreu et al., 1996). As fontes utilizadas promoveram teores crescentes de manganês na matéria seca da parte aérea, sendo que os maiores teores foram obtidos pela aplicação de sulfato de manganês em relação ao óxido.

Em experimento conduzido em vaso pela técnica do elemento faltante, Mann et al. (1999a), trabalhando com a variedade CAC-1 num solo de pH 6,8 e saturação por bases de $76 \%$ encontraram redução média de $13,8 \%$ na produção, em relação ao tratamento completo, pela omissão na aplicação ao solo de manganês.

Avaliando a resposta da soja variedade IAC-14 ao efeito residual do manganês aplicado em um Latossolo Vermelho Amarelo álico de cerrado, Oliveira et al. (1999) concluíram que, em condições de casa de vegetação, as maiores produções de grãos foram obtidas com as doses de 50 e $100 \mathrm{mg} \mathrm{dm}^{-3}$ de manganês.

A capacidade das folhas de absorção de nutrientes depositados na forma de solução, em sua superfície, permite o fornecimento dos mesmos, particularmente dos micronutrientes, pela prática da adubação foliar. 
Foram obtidos aumentos significativos de produção de soja pela aplicação foliar de $0,17 \mathrm{~kg}$ de $\mathrm{Mn}$ por hectare, fornecido na forma de Mn-EDTA (Randall et al., 1975a).

Ohki et al. (1987) observaram que as aplicações foliares de sulfato de manganês e Mn EDTA são utilizadas com mais freqüência no controle da deficiência de manganês em relação a outras fontes.

Em área de cerrado infestada com nematóide de cisto da soja (Heterodera glycines), a aplicação foliar de $700 \mathrm{~kg}$ por hectare de sulfato de manganês resultou em incremento de produção da ordem de $360 \mathrm{~kg}$ por hectare de soja, cultivar Garimpo (Zito et al., 1999).

Uma das vantagens mais enfatizadas da adubação foliar é o alto índice de utilização pelas plantas dos nutrientes aplicados nas folhas em relação à aplicação no solo. No solo, os nutrientes estão sujeitos a reações de insolubilização ou de perdas por lixiviação, ao passo que quando aplicados nas folhas são em grande parte absorvidos. Assim, as doses necessárias na adubação foliar são menores do que na adubação no solo (Volkweiss, 1991).

Alley et al. (1978), utilizando a fonte sulfato de manganês, obtiveram produções semelhantes aplicando: $2,2 \mathrm{~kg}$ hectare $^{-1}$ de $\mathrm{Mn}$ via foliar, em dois parcelamentos de $1,1 \mathrm{~kg}$ hectare $^{-1}$ antes do florescimento; 5,6 a $16,8 \mathrm{~kg}$ hectare $^{-1}$ de $\mathrm{Mn}$ no sulco de semeadura e 11,2 a $44,8 \mathrm{~kg}$ hectare ${ }^{-1}$ de $\mathrm{Mn}$, a lanço em cobertura. Houve comprometimento da emergência e, portanto, do estande, nas maiores doses aplicadas no sulco de semeadura. Os resultados obtidos por estes autores mostraram maior eficiência, em relação à dose fornecida, na aplicação foliar do elemento.

Estudando o efeito residual, sobre a cultura da soja, da adubação de trigo com micronutrientes, aplicada em solo virgem de cerrado, Silva et al (1986) não obtiveram resposta em função da aplicação de $2090 \mathrm{~g} \mathrm{ha}^{-1}$ de manganês, durante dois anos de avaliação.

Avaliando, em condições de campo, o efeito de micronutrientes no rendimento de grãos, número e peso de nódulos da soja (cv. Savana), num 
latossolo vermelho-amarelo, Galrão (1991), não obteve, para estes parâmetros, resposta durante 4 anos consecutivos à aplicação de $4000 \mathrm{~g} \mathrm{ha}^{-1}$ de $\mathrm{Mn}$ na forma de sulfato de manganês, embora tenha encontrado aumento nos teores de $\mathrm{Mn}$ no solo (de 3,8 a 4,2 para 4,6 a 5,5 $\mathrm{mg} \mathrm{dm}^{-3}$, Mehlich-1) e nas folhas (de 35 a 62 para 40 a $70 \mathrm{mg} \mathrm{kg}^{-1}$ ) de em relação à testemunha.

Em condições de casa de vegetação Mann et al. (1999b) concluíram que uma aplicação foliar de manganês aos 20 ou 30 dias após a emergência do cultivar Garimpo resultaram em produção $14,4 \%$ superior a testemunha sem manganês, enquanto que a aplicação de $14 \mathrm{mg} \mathrm{dm}^{-3}$ via solo superou em média $8 \%$ a aplicação foliar (em relação produção), num solo de pH 6,8, saturação por bases de $76 \%$ e teor de manganês de $3,4 \mathrm{mg} \mathrm{dm}^{-3}$.

\subsection{Nutrição e qualidade de sementes}

Plantas cultivadas de modo adequado e equilibrado apresentam condições de produzir maior quantidade de sementes, aliada à melhor qualidade, haja visto que as mesmas poderão resistir mais facilmente a adversidades que surgirem no período de produção (Sá, 1994).

$\mathrm{O}$ aspecto nutricional das plantas tem-se mostrado, em várias pesquisas, como fator que afeta tamanho, peso e vigor de sementes, sendo que em muitos casos esses efeitos podem estar ligados à permeabilidade e integridade das membranas dos tecidos das sementes, se considerar que diversos nutrientes atuam como ativadores enzimáticos ou vão se constituir em componentes dessas membranas (Sá, 1994). O fato mais relevante é que, em situações de deficiência nutricional, esses efeitos se tornam mais pronunciados.

Uma planta bem nutrida reúne condições de produzir sementes em maior quantidade e mais bem formadas. A exigência nutricional das culturas, para a maioria das espécies, torna-se mais intensa com 0 início da fase reprodutiva, sendo mais crítica por ocasião da formação das sementes, quando 
considerável quantidade de nutrientes são para elas translocados. Esta maior exigência deve-se ao fato dos nutrientes serem necessários à formação e ao desenvolvimento de novos órgãos e de materiais de reserva que ali serão armazenados (Carvalho \& Nakagawa, 1988). A disponibilidade de nutrientes influi na formação do embrião e dos órgãos de reserva, assim como na composição química da semente, tendo consequentemente efeitos sobre seu vigor e qualidade.

Poucas pesquisas têm sido realizadas visando verificar as relações existentes entre a fertilidade do solo, nutrientes fornecidos às plantas e qualidade das sementes produzidas. Pela literatura consultada não foram encontrados trabalhos em soja relacionando efeitos de manganês e qualidade de sementes.

Segundo Delouche (1980), as plantas desenvolveram extraordinária capacidade de ajustar a produção de sementes aos recursos disponíveis. A resposta típica de plantas à baixa fertilidade do solo ou à falta de água é em primeiro lugar a redução na quantidade de sementes e posteriormente na sua qualidade. As poucas sementes produzidas sob condições marginais são, normalmente, tão viáveis e vigorosas quanto as produzidas em situações favoráveis. Sob o ponto de vista da evolução, o ajuste da produção de sementes aos recursos disponíveis tem alto valor para a sobrevivência; essas poucas sementes teriam a mesma ou maior chance de germinar e se desenvolver em condições adversas.

Harris et al. (1965) não encontraram efeito do molibdênio sobre a qualidade de sementes de soja, nos diversos locais em que o experimento foi realizado.

De acordo com observaçöes de Scoth \& Aldrich (1975), $75 \%$ do nitrogênio e do fósforo e $60 \%$ do potássio, retirados do solo pelas plantas de soja estão contidos nas sementes, revelando a importância da adubação na formação dos órgãos de reserva (cotilédones) os quais irão se constituir na 
principal fonte de nutrição para as plântulas durante as primeiras duas semanas após a germinação.

Trabalho com soja, visando verificar o efeito de doses de calcário dolomítico e fósforo na qualidade da semente, foi realizado por Turkiewicz (1976). Os resultados mostraram que tanto a calagem quanto a adubação fosfatada afetaram a qualidade das sementes, sendo que a ausência de calcário e a dose mais elevada de fósforo $\left(640 \mathrm{~kg} \mathrm{ha}^{-1}\right.$ de $\left.\mathrm{P}_{2} \mathrm{O}_{5}\right)$ prejudicaram a germinação e o vigor das mesmas.

Estudos mostrando os efeitos da adubação sobre o tamanho ou peso da semente foram conduzidos em diversas culturas e alguns trabalhos associaram tamanho e/ou peso da semente com germinação e vigor. Resultados positivos indicando o desempenho superior de sementes de maior tamanho sobre as de menor tamanho, em soja, foram obtidos por Smith \& Camper (1970), Fehr \& Probst (1971), Fontes \& Ohlrogge (1972), Aguiar (1979), entre outros.

O papel dos nutrientes é fundamental na formação das sementes, principalmente no que diz respeito à constituição de membranas e acúmulo de carboidratos, lipídios e proteinas. As funções de ativação enzimática, biossíntese, transferência de energia e regulação hormonal são características fundamentais do aspecto de formação, desenvolvimento e maturação das sementes e, assim, tanto macro quanto micronutrientes apresentam importância similar nesses eventos (Sá, 1994).

Pela sua natureza, o manganês desempenha várias funções na vida da planta, determinando ou influenciando diversos processos, tais como síntese de proteina, absorção iônica, respiração, síntese de amido e controle hormonal. Assim, pode-se inferir que direta ou indiretamente o manganês está envolvido na qualidade das sementes. 


\subsection{Efeito da nutrição sobre os teores de proteína e óleo nos grãos}

A soja constitui-se em fonte rica de proteínas e lipídios, sendo consumida pela população na forma de óleo e seus derivados, como extrato hidrossolúvel (leite de soja), como proteína texturizada e cada vez mais como matéria prima para produtos industrializados.

A maioria dos cultivares de soja apresentam de $30-45 \%$ de proteínas, de $15-25 \%$ de lipídeos, de $20-35 \%$ de carboidratos e cerca de $5 \%$ de cinzas em suas sementes. Quando processados, $100 \mathrm{~kg}$ de soja produzem em média,79 $\mathrm{kg}$ de farelo (cerca de $50 \%$ de proteína) e $18,4 \mathrm{~kg}$ de óleo (Moreira, 1999).

O óleo de soja é o líder mundial dos óleos vegetais, representando mais de $30 \%$ do total (Vello, 1999), sendo responsável por $20-24 \%$ de todas as gorduras e óleos produzidos no mundo. No Brasil, o óleo de soja participa em mais de $50 \%$ dos óleos e gorduras presentes nos produtos alimentícios.

Além do consumo interno significativo, o Brasil, juntamente com os Estados Unidos, Argentina e União Européia, atendem cerca de $90 \%$ do volume mundial de óleo de soja (EMBRAPA, 1997). No mercado internacional de grãos, a soja brasileira tem sido muito valorizada, principalmente devido apresentar acréscimo de cerca de $1,25 \%$ no teor de óleo, comparativamente à soja produzida em regiões temperadas (Hill et al., 1996).

Dos produtos protéicos de soja a maioria é utilizada na alimentação de aves, suínos, bovinos e outros animais domésticos como fonte de proteína (farelos).

Assim, para atender as demandas por óleo e proteína de soja torna-se fundamental o conhecimento dos diversos fatores que podem levar à manutenção e, principalmente, ao aumento da produtividade desses produtos.

Pela literatura, observou-se que muitos trabalhos relacionaram influências ambientais e genéticas na produção de óleo e proteína (Fontes et al., 1974; Teixeira et al., 1979; Oliveira et al., 1991; Mandarino et al., 1993). 
Por outro lado, fatores nutricionais podem influenciar os teores de óleo e proteína dos grãos. Algumas pesquisas têm mostrado essas relações.

Mascarenhas et al. (1990) avaliaram o efeito da aplicação de níveis crescentes de calcário dolomítico $(0,4,8$ e 12 t ha-1 $)$ em diferentes cultivares de soja, verificando aumento no teor de óleo nos grãos promovido pela calagem. Nesse sentido, Tanaka \& Mascarenhas (1995) observaram resultados semelhantes pela aplicação de calcário e gesso.

Alguns trabalhos apontam relação entre manganês e teores de óleo e proteína nos grãos de soja.

A deficiência de manganês causa elevação no teor de proteína e redução no teor de óleo dos grãos (Wilson et al., 1982). Com o aumento do teor de manganês na folha, do nível de deficiente até o suficiente, há aumento na concentração de óleo nos grãos de soja de 22 para $26 \%$ e queda no teor de proteína de 48 para 38\% (Tanaka et al.,1993).

Tanaka \& Mascarenhas (1992) sugerem correlação positiva entre os teores foliares de manganês e produção de óleo pelo grão.

Como observado anteriormente, verifica-se que tanto a calagem quanto o fornecimento de manganês podem influenciar a produção de óleo e proteína dos grãos. Estes fatores podem estar direta ou indiretamente relacionados, uma vez que a reação do solo, conforme descrito ao longo da presente revisão, é um fator que interfere na disponibilidade do manganês às plantas. 


\section{MATERIAL E MÉTODOS}

A pesquisa foi conduzida em duas partes, sendo a primeira realizada em condições de casa de vegetação e, a segunda, em condições de campo, discriminadas a seguir.

\subsection{Experimentos em casa de vegetação}

\subsubsection{Local e periodo de experimentação}

Os experimentos foram instalados em condições de casa de vegetação no Departamento de Solos e Nutrição de Plantas da Escola Superior de Agricultura "Luiz de Queiroz" (USPI ESALQ), no município de Piracicaba, SP, situado a $22^{\circ} 41^{\prime} 30^{\prime \prime}$ de latitude Sul, $47^{\circ} 38^{\prime} 30^{\prime \prime}$ de longitude Oeste e $546 \mathrm{~m}$ de altitude.

Foram conduzidas duas épocas experimentais em condições de casa de vegetação, sendo a primeira (época 1) no período de novembro de 1998 a fevereiro de 1999 e, a segunda (época 2) no período de janeiro a abril de 1999.

\subsubsection{Características e preparo do solo}

O solo utilizado, classificado como Latossolo Vermelho Amarelo distrófico muito argiloso, foi coletado da camada $0-20 \mathrm{~cm}$ de uma área de produção comercial de soja, na região do cerrado, localizada no município de 
Uberaba (MG), onde a ocorrência de deficiência de manganês vinha sendo constatada.

O solo foi peneirado, destorroado e homogeneizado, seco ao ar (TFSA) e passado em peneira com malha de $2 \mathrm{~mm}$ de abertura; em seguida, foi realizada uma amostragem composta. Suas características físicas e químicas foram determinadas no Laboratório de Análises Químicas de Solo do Departamento de Solos e Nutrição de Plantas da USPIESALQ e estão apresentadas nas Tabelas 1, 2 e 3 respectivamente.

Tabela 1. Resultado da análise granulométrica do Latossolo Vermelho Amarelo distrófico muito argiloso, proveniente do município de Uberaba (MG).

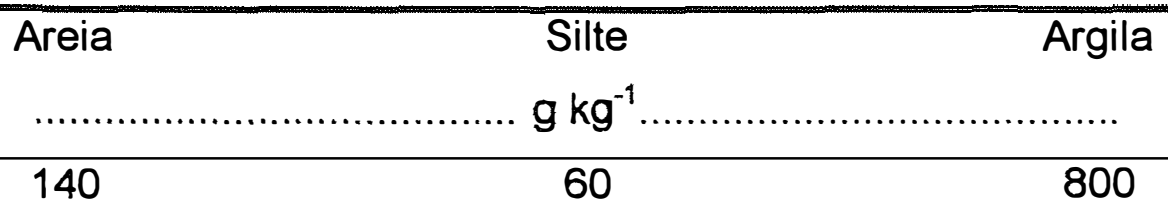

Tabela 2. Resultados das análises químicas do Latossolo Vermelho Amarelo distrófico muito argiloso, proveniente do município de Uberaba (MG).

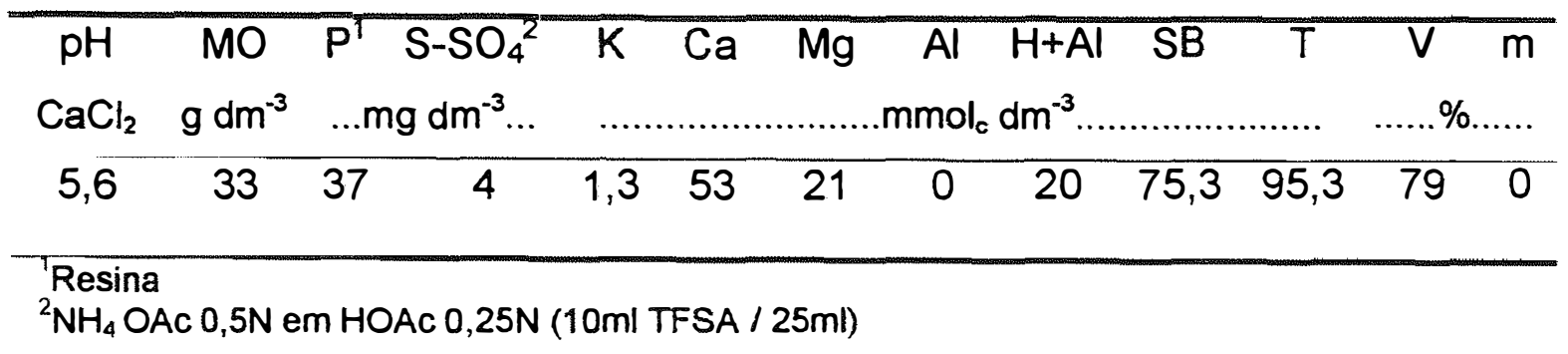


Tabela 3. Resultados das análises químicas de micronutrientes e sódio do Latossolo Vermelho Amarelo distrófico muito argiloso, proveniente do município de Uberaba (MG).

\begin{tabular}{|c|c|c|c|c|c|}
\hline $\mathrm{B}^{-}$ & $\mathrm{Cu}^{2}$ & $\mathrm{Fe}^{2}$ & $\overline{\mathrm{Mn}^{2}}$ & $\mathrm{Zn}^{2}$ & $\mathrm{Na}^{2}$ \\
\hline \multicolumn{6}{|c|}{ 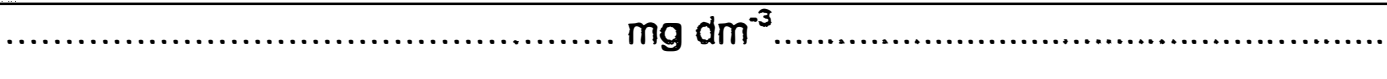 } \\
\hline 0,46 & 1,1 & 36,4 & 2,2 & 3,3 & 4,6 \\
\hline
\end{tabular}

\subsubsection{Cultivar}

O cultivar de soja utilizado na pesquisa foi a MG/BR-48 (GARIMPO $\mathrm{RCH}$ ), indicada para cultivo comercial no Estado de Minas Gerais, que dentre as suas características principais destaca-se a resistência ao cancro da haste, à pústula bacteriana, a mancha "olho-de-rã" e a oídio, a tolerância ao nematóide de galha (Meloidogyne javanica) e o período juvenil longo. É do tipo de crescimento determinado e com ciclo total (emergência à maturação) de 110 dias, em Minas Gerais. Possui flor branca, pubescência marrom, vagem marrom clara, semente de tegumento amarelo semi-brilhante com hilo preto e peso médio de 100 sementes de 14,3g. Apresenta altura média das plantas de $87 \mathrm{~cm}$, boa resistência ao acamamento e à deiscência das vagens e semente com boa qualidade fisiológica. Os teores médios de óleo e proteína dos grãos são respectivamente, de $23,2 \%$ e $42,4 \%$ (Arantes et al., 1999).

O cultivar é considerado um dos mais sensiveis à deficiência de manganês (Abreu et al., 1994). 


\subsubsection{Instalação dos experimentos}

\subsubsection{Recipientes}

Foram utilizados vasos de plásticos, inicialmente translúcidos, com capacidade para $2,5 \mathrm{~kg}$ de TFSA, os quais receberam externamente uma pintura com tinta prateada para evitar aquecimento e entrada de luz nas raizes (Figura 1). Foram feitos coletores na base de cada vaso para facilitar a aeração e possivel escoamento do excesso de água. Para evitar perdas por lixiviação, a água escoada era conduzida a um frasco e, posteriormente, retornada ao vaso.

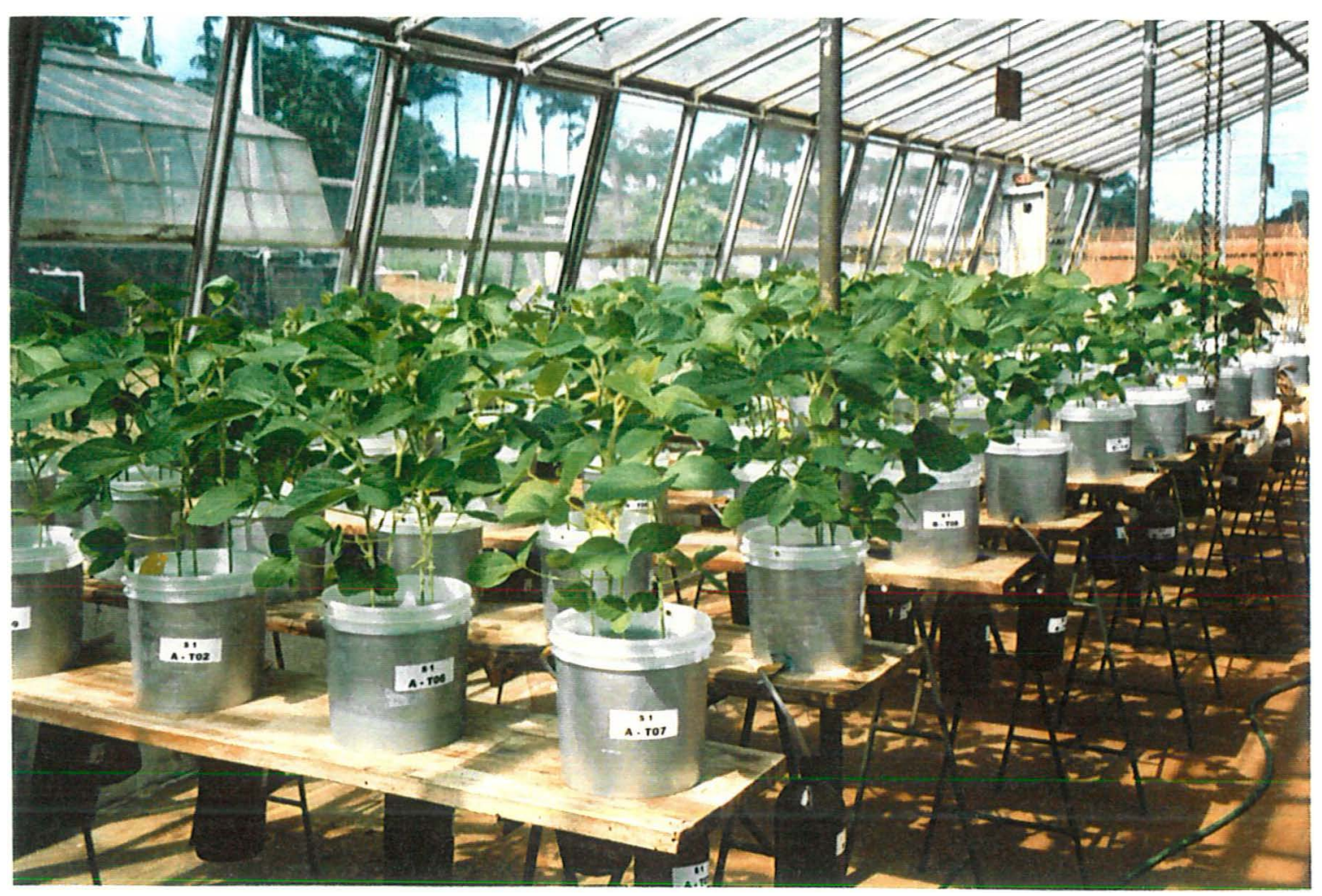

Figura 1. Aspecto geral do experimento em casa de vegetação mostrando os recipientes e os coletores utilizados. 


\subsubsection{Adubação básica e enchimento dos vasos}

Foram colocados $2,5 \mathrm{~kg}$ de solo (quantidade utilizada por vaso) em bandeja plástica. Em seguida, realizou-se adubação básica com superfosfato simples e com solução de potássio e micronutrientes, que foram distribuídos uniformemente sobre o solo e homogeneizados (Tabela 4). Posteriormente, 0 solo adubado foi colocado no interior dos vasos.

Tabela 4. Quantidade de nutrientes e fontes utilizadas na adubação básica dos vasos nos experimentos em casa de vegetação*.

\begin{tabular}{|c|c|c|c|c|}
\hline Nutrientes & $\begin{array}{c}\text { Dose } \\
\left(\mathrm{mg} \mathrm{kg}^{-1}\right)\end{array}$ & Fonte & $\begin{array}{l}\text { Concentração da } \\
\text { solução }\left(\mathrm{mg} \mathrm{L}^{-1}\right)\end{array}$ & Dose aplicada \\
\hline$P$ & 200 & superfosfato simples & - & $2,6 \mathrm{~g} \mathrm{dm}^{-3}$ de solo \\
\hline $\mathrm{K}$ & $\begin{array}{c}50 \\
100\end{array}$ & $\mathrm{KCl}$ & 8365 & $\begin{array}{c}12 \mathrm{~mL} \mathrm{dm}^{-3} \text { de solo } \\
\text { (plantio) } \\
24 \mathrm{~mL} \mathrm{dm}^{-3} \text { de solo } \\
\text { (cobertura) }\end{array}$ \\
\hline B & 0,5 & $\mathrm{H}_{3} \mathrm{BO}_{3}$ & 238 & $12 \mathrm{~mL} \mathrm{dm}^{-3}$ de solo \\
\hline $\mathrm{Cu}$ & 1,5 & $\mathrm{CuSO}_{4} \cdot 5 \mathrm{H}_{2} \mathrm{O}$ & 491 & $12 \mathrm{~mL} \mathrm{dm}^{-3}$ de solo \\
\hline $\mathrm{Zn}$ & 3,6 & $\mathrm{ZnSO}_{4} .7 \mathrm{H}_{2} \mathrm{O}$ & 1832 & $12 \mathrm{~mL} \mathrm{dm}^{-3}$ de solo \\
\hline $\mathrm{Fe}$ & 5,0 & Fe-EDTA & 6570 & $1 \mathrm{~mL} \mathrm{dm}^{-3}$ de solo \\
\hline
\end{tabular}

\subsubsection{Delineamento experimental}

Tanto na época 1 quanto na 2 os experimentos foram instalados segundo delineamento experimental em blocos casualizados, com 10 
tratamentos e 4 repetições, totalizando 40 parcelas. Cada parcela foi composta por um vaso com 3 plantas.

\subsubsection{Tratamentos}

Como tratamentos foram utilizadas fontes de manganês aplicadas via foliar, solo e semente (Tabela 5).

Tabela 5. Esquema de tratamentos, produtos, doses e via de aplicação, nos experimentos em casa de vegetação.

\begin{tabular}{|c|c|c|c|c|}
\hline \multirow[t]{2}{*}{ Tratamento } & \multirow{2}{*}{$\begin{array}{c}\text { Fonte de } \\
\text { manganês }\end{array}$} & \multirow{2}{*}{$\begin{array}{c}\text { Via de } \\
\text { Aplicação }\end{array}$} & \multicolumn{2}{|c|}{ Dose de manganês } \\
\hline & & & & $\left(\mathrm{g} \mathrm{ha}^{-1}\right)$ \\
\hline 1 & Testemunha & - & - & - \\
\hline 2 & $\mathrm{MnSO}_{4} 4 \mathrm{H}_{2} \mathrm{O}$ & foliar & $0,93 \mathrm{~g} \mathrm{~L}^{-1}$ de solução & $350^{*}$ \\
\hline 3 & $\mathrm{MnSO}_{4} 4 \mathrm{H}_{2} \mathrm{O}$ & foliar & $0,53 \mathrm{~g} \mathrm{~L}^{-1}$ de solução & $200^{*}$ \\
\hline 4 & Quelado $\mathrm{Cl}^{-}$ & foliar & $0,53 \mathrm{~g} \mathrm{~L}^{-1}$ de solução & $200^{*}$ \\
\hline 5 & Quelado $\mathrm{NO}_{3}^{-}$ & foliar & $0,53 \mathrm{~g} \mathrm{~L}^{-1}$ de solução & $200^{*}$ \\
\hline 6 & Quelado $\mathrm{SO}_{4}^{-2}$ & foliar & $0,53 \mathrm{~g} \mathrm{~L}^{-1}$ de solução & $200^{*}$ \\
\hline 7 & Mancozeb & foliar & $0,53 \mathrm{~g} \mathrm{~L}^{-1}$ de solução & $200^{*}$ \\
\hline 8 & $\mathrm{MnSO}_{4} \cdot 4 \mathrm{H}_{2} \mathrm{O}$ & solo & $2 \mathrm{mg} \mathrm{dm}^{-3}$ de solo & $4000^{* *}$ \\
\hline 9 & Oxi-sulfato Mn & solo & $2 \mathrm{mg} \mathrm{dm}^{-3} \mathrm{de}$ solo & $4000^{* *}$ \\
\hline 10 & Quelado $\mathrm{SO}_{4}^{-2}$ & semente & $5 \mathrm{~g} \mathrm{~kg}^{-1}$ de semente & $300^{* * *}$ \\
\hline
\end{tabular}

Dose por aplicação de $1,25 \mathrm{ml}$ de solução por planta, considerando 300.000 plantas ha"

" Considerando $1 \mathrm{ha}=2 \times 10^{6} \mathrm{dm}^{3}$ de solo.

Considerando $60 \mathrm{~kg} \mathrm{ha}^{-1}$ de semente.

A aplicação foliar de sulfato de manganês (tratamento 2), fornecendo $350 \mathrm{~g} \mathrm{ha}^{-1}$ de $\mathrm{Mn}$, está de acordo com as recomendaçōes técnicas para a cultura da soja (Embrapa, 1996). Quando o manganês foi fornecido na forma 
$\mathrm{MnSO}_{4} 4 \mathrm{H}_{2} \mathrm{O}$ (tratamento 3 ) e de quelado (tratamentos 4,5 e 6 ), a dose foi reduzida para $200 \mathrm{~g} \mathrm{ha}^{-1}$ de $\mathrm{Mn}$, com o objetivo de avaliar a eficiência das diferentes fontes testadas. No caso do mancozeb (tratamento 7), a dose de manganês foi $200 \mathrm{~g} \mathrm{ha}^{-1}$ para servir de comparativo com as fontes quelatizadas.

Com relação à aplicação via solo, foram utilizadas duas fontes de manganês, sulfato de manganês (tratamento 8 ) e oxi-sulfato de Mn (tratamento 9), fornecendo $4000 \mathrm{~g} \mathrm{ha}^{-1}$ de $\mathrm{Mn}$, conforme recomendação oficial (Embrapa, 1996).

Quanto à adubação via semente (tratamento 10), foi utilizada uma fonte quelatizada a base de sulfato de manganês (quelado $\mathrm{SO}_{4}{ }^{-2}$ ) na dose de $5 \mathrm{~g}$ de $\mathrm{Mn} \mathrm{kg}^{-1}$ de semente, para fornecer o equivalente a $300 \mathrm{~g} \mathrm{ha}^{-1}$ de $\mathrm{Mn}$.

Os produtos quelado $\mathrm{Cl}^{-}$, quelado $\mathrm{NO}_{3}{ }^{-}$e quelado $\mathrm{SO}_{4}^{-2}$ são fontes de manganês quelatizado formuladas a partir de cloreto, nitrato e sulfato de manganês, respectivamente, utilizando como agente quelante o quelado natural lignossulfonato. $O$ produtos são apresentados na forma de solução.

O mancozeb, produto de coordenação iônica de etilenobisditiocarbamato de manganês e íon zinco, é um fungicida com ação de contato do grupo químico ditiocarbamato. $O$ tipo de formulação utilizado foi o pó molhável e a concentração do princípio ativo (mancozeb) de $800 \mathrm{~g} \mathrm{~kg}^{-1}$.

$\mathrm{O}$ produto oxi-sulfato de manganês é obtido pelo ataque parcial de ácido sulfúrico sobre óxidos de manganês. Este processo leva a um efeito aglomerante do material, resultando na formação de grânulos. Assim, o produto final é uma fonte de manganês parcialmente solúvel em água.

A concentração de nutrientes nos produtos utilizados (Tabela 6 ) foi determinada no Laboratório de Análises Químicas de Solo do Departamento de Solos e Nutrição de Plantas da USP/ESALQ. 
Tabela 6. Teores totais de nutrientes encontrados nos produtos utilizados.

\begin{tabular}{|c|c|c|c|c|c|c|c|c|}
\hline Produto & $\mathrm{N}$ & S & $\mathrm{B}$ & $\mathrm{Cl}$ & $\mathrm{Cu}$ & $\overline{\mathrm{Fe}}$ & $\overline{M n}$ & $\overline{Z n}$ \\
\hline & \multicolumn{8}{|c|}{$\mathrm{g} \mathrm{kg}^{-1}$. } \\
\hline $\mathrm{MnSO}_{4} 4 \mathrm{H}_{2} \mathrm{O}$ & - & 140 & - & - & - & - & 250 & - \\
\hline Quelado $\mathrm{Cl}^{-}$ & - & - & - & 85 & - & - & 70 & - \\
\hline Quelado $\mathrm{NO}_{3}^{-}$ & 20 & - & - & & - & - & 70 & - \\
\hline Quelado $\mathrm{SO}_{4}^{-2}$ & 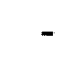 & 30 & - & 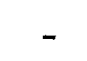 & - & - & 70 & - \\
\hline Mancozeb & 90 & 30 & - & - & - & - & 170 & 20 \\
\hline Oxi-sulfato Mn & - & 130 & 5 & 60 & 25 & 66 & 220 & 23 \\
\hline
\end{tabular}

\subsubsection{Sementes}

\subsection{Análise de sementes}

O resultado das análises químicas das sementes utilizadas nos experimentos encontra-se na Tabela 7.

Tabela 7. Teores de macro e micronutrientes encontrados nas sementes utilizadas

\begin{tabular}{|c|c|c|c|c|c|c|c|c|c|c|}
\hline $\bar{N}$ & $\mathrm{P}$ & $\bar{K}$ & $\mathrm{Ca}$ & $\overline{\mathrm{Mg}}$ & $\bar{S}$ & $\mathrm{~B}$ & $\mathrm{Cu}$ & $\mathrm{Fe}$ & $\mathrm{Mn}$ & $\mathrm{Zn}$ \\
\hline \multicolumn{6}{|c|}{$\mathrm{g} \mathrm{kg}^{-1}$} & \multicolumn{5}{|c|}{ 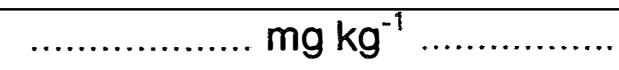 } \\
\hline 55,2 & 4,5 & 17,5 & 2,5 & 2,4 & 2,6 & 18 & 11 & 86 & 19 & 43 \\
\hline
\end{tabular}

\subsection{Tratamento de sementes}

Uma solução (densidade $=1,25$ ) contendo $10 \%$ de molibdênio e $1,5 \%$ de cobalto foi aplicada às sementes na quantidade de $1,9 \mathrm{~mL} \mathrm{~kg}^{-1}$ de semente (equivalente a aproximadamente $15 \mathrm{~g} \mathrm{ha}^{-1}$ de Mo e $2 \mathrm{~g} \mathrm{ha}^{-1} \mathrm{de}$ Co). 
Posteriormente, as sementes foram inoculadas com a bactéria Bradyrhizobium japonicum em meio turfoso esterilizado na dose de $5 \mathrm{~g} \mathrm{~kg}^{-1}$ de semente. $O$ teor de $\mathrm{Mn}$ encontrado no inoculante foi inexpressivo $\left(0,12 \mathrm{mg} \mathrm{kg}^{-1}\right)$, não interferindo, portanto, nos tratamentos.

\subsubsection{Condução dos experimentos}

\subsubsection{Aplicação dos tratamentos via solo e via semente}

Os tratamentos, via solo, foram aplicados diretamente nos vasos antes da semeadura e distribuidos uniformemente na superfície do solo. No caso do tratamento 8 ( $\mathrm{MnSO}_{4} 4 \mathrm{H}_{2} \mathrm{O}$, dose de $\mathrm{Mn}: 2 \mathrm{mg} \mathrm{dm}^{-3}$ de solo), utilizou-se uma solução de $677 \mathrm{mg} \mathrm{L}^{-1}$ de $\mathrm{MnSO}_{4} \cdot 4 \mathrm{H}_{2} \mathrm{O}$ da qual foram aplicados $30 \mathrm{~mL}$ por vaso (12 $\mathrm{mL} \mathrm{dm}^{-3}$ de solo). Quanto ao tratamento 9 (Oxi-sulfato $\mathrm{Mn}$, dose de $\mathrm{Mn}: 2$ $\mathrm{mg} \mathrm{dm^{3 }}$ de solo), aplicaram-se, de maneira homogênea, $22,7 \mathrm{mg}$ de produto diretamente na superfície do solo.

Com relação ao tratamento via semente (tratamento 10), a solução de quelado $\mathrm{SO}_{4}{ }^{-2}$ (densidade $=1,25$ ) foi aplicada às sementes na quantidade de $57 \mathrm{~mL} \mathrm{~kg}^{-1}$ de semente (equivalente a aproximadamente $300 \mathrm{~g} \mathrm{ha}^{-1} \mathrm{de} \mathrm{Mn}$ ). Esta operação foi realizada juntamente com a adubação de Co e Mo e anteriormente à inoculação.

\subsubsection{Semeadura}

Após a adição de água destilada no vaso, de modo a elevar a umidade do solo para 2/3 da capacidade de campo, as sementes (em número de seis) foram distribuídas uniformemente por vaso, à profundidade de aproximadamente $2 \mathrm{~cm}$. 


\subsubsection{Irrigação}

Uma vez por dia, até aproximadamente um mês após a semeadura, e posteriormente duas vezes por dia, até próximo do final do ciclo da cultura, os vasos foram irrigados com quantidade de água destilada suficiente para repor a evapotranspiração.

\subsubsection{Desbaste}

Catorze dias após a emergência das plântulas, quando o primeiro trifólio estava completamente desenvolvido, correspondente ao estádio vegetativo $V_{2}$ (Fehr \& Caviness, 1977), procedeu-se ao desbaste deixando-se três plantas por vaso.

\subsubsection{Adubação em cobertura}

Quatro semanas após a semeadura procedeu-se a aplicação de 60 $\mathrm{mL}$ por vaso (24 mL dm${ }^{-3}$ de solo) de uma solução contendo $8365 \mathrm{mg} \mathrm{L}^{-1}$ de $\mathrm{KCl}$ a fim de fornecer $100 \mathrm{mg} \mathrm{kg}^{-1}$ de potássio, conforme fora descrito na Tabela 4.

\subsubsection{Controle de pragas}

Sempre que necessário foi realizado o controle de ácaros e insetos através da aplicação de acaricida (propargite) e inseticida acaricida (clorpirifós). 


\subsubsection{Amostragem de folhas}

No primeiro experimento (época 1), a primeira amostragem de folhas foi feita quando a maioria das plantas estava no estádio reprodutivo $R_{1}$ (Fehr \& Caviness, 1977), precedendo a aplicação dos tratamentos via foliar, e a segunda quando a maioria das plantas estava no estádio $R_{4}$. No segundo experimento (época 2), foram realizadas três amostragens de folhas, sendo a primeira quando a maioria das plantas estava no estádio vegetativo $V_{4}$, a segunda quando a maioria das plantas estava no estádio reprodutivo $R_{1}$ (ambas precedendo a aplicação foliar) e, a terceira, quando a maioria das plantas estava no estádio $\mathrm{R}_{4}$. Em cada uma das amostragens, foi coletada, de cada planta do vaso, a terceira folha desenvolvida com pecíolo à partir do ápice da planta na haste principal .

\subsubsection{Aplicação dos tratamentos via foliar}

Os tratamentos via foliar $(2,3,4,5,6$ e 7$)$ foram aplicados uma única vez no primeiro experimento (época 1), quando a maioria das plantas estavam no estádio $R_{1}$. No experimento (época 2), foram feitas duas aplicações: a primeira quando a maioria das plantas estavam no estádio $\mathrm{V}_{4} \mathrm{e}$, a segunda, quando a maioria das plantas estavam no estádio $R_{1}$. Esta aplicação foi realizada com pulverizador manual sobre as plantas de cada tratamento, isoladamente, a fim de evitar contaminação dos demais tratamentos por eventual deriva. $O$ volume de calda aplicado foi de $1,25 \mathrm{~mL}$ por planta.

\subsubsection{Coleta dos experimentos}

Durante o periodo experimental, as folhas senescentes foram recolhidas e acondicionadas em sacos de papel, devidamente identificados. 
No final do ciclo da cultura, fase $R_{8}$, (112 dias após a semeadura, tanto na época 1 quanto na época 2), procedeu-se a coleta das vagens e dos ramos separadamente, quando então todas as folhas já haviam sido recolhidas. Posteriormente, foi retirada uma amostra de solo, por vaso, seguida de coleta das raizes, que foram lavadas em água corrente.

\subsubsection{Avaliações dos experimentos}

\subsubsection{Teor de clorofila}

Durante a amostragem de folhas, conforme descrito no item 3.1.5.7, foi realizada a avaliação no teor de clorofila por meio do aparelho SPAD-502 desenvolvido pela empresa Minolta (Figura 2) que fornece leituras (unidades "SPAD") que correspondem ao teor do pigmento existente na folha. Os valores são equivalentes à quantidade de luz transmitida pela folha em duas regiōes de comprimento de onda, nas quais a absorção pela clorofila é diferente (Malavolta et al., 1997). Assim, o valor fornecido é proporcional à quantidade de clorofila existente na folha.

O instrumento tem sido usado para avaliar o teor de nitrogênio da folha, visto que $\mathrm{N}$ e clorofila se correlacionam positivamente. No caso do $\mathrm{Mn}$, pode-se inferir que há uma correlação positiva entre teor de clorofila e teor do elemento na folha.

A leitura foi feita no terço superior do limbo do folíolo central da terceira folha desenvolvida à partir do ápice da planta na haste principal (a mesma folha amostrada para diagnose foliar).

A concentração de clorofila foi estimada relacionando-se leituras do aparelho $(x)$ com o teor de clorofila $(y)$, de acordo com a equação, determinada pelo método de Barnes et al. (1992):

$$
y=0,0996 x-0,152\left(R^{2}=0,664\right)
$$




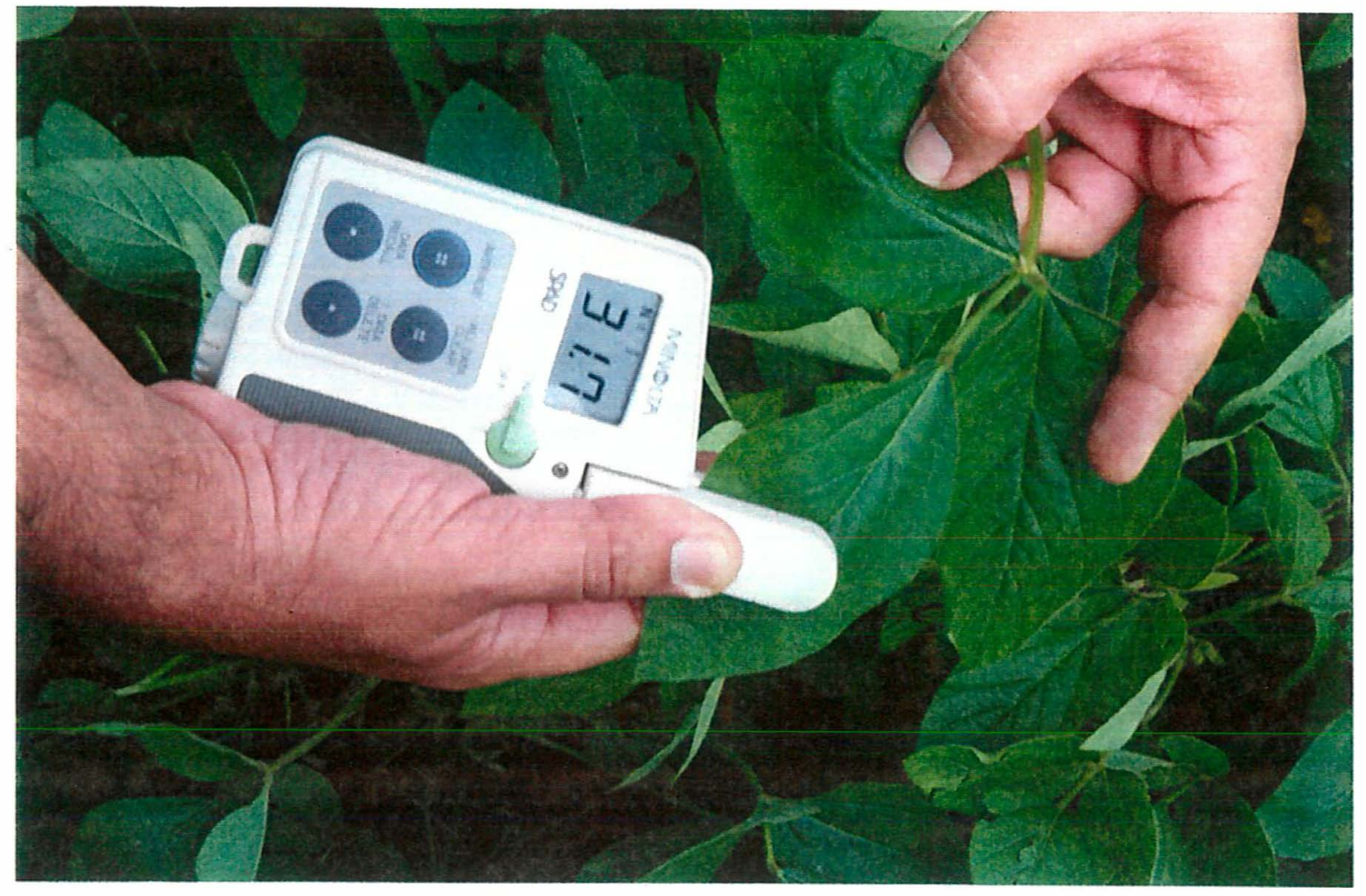

Figura 2. Leitura direta do teor de pigmento por meio do aparelho clorofilômetro (SPAD 502 - Minolta).

\subsubsection{Diagnose foliar}

As amostras de folhas, após serem lavadas, secas em estufa, moídas e pesadas foram submetidas à digestão e quantificação segundo a metodologia descrita a seguir.

Para determinação de $\mathrm{N}$, ○ material vegetal moído submeteu-se à digestão sulfúrica e destilação em microdestilador Kjeldahl. Para ० B, a digestão foi pelo processo de incineração em meio alcalino e a determinação feita por colorimetria pela Azometina $\mathrm{H}$. Para os demais elementos a digestão realizada foi a nitro-perclórica, por via úmida. O P foi determinado por colorimetria do metavanadato; o K pela fotometria de chama; o $\mathrm{S}$ por turbedimetria do sulfato de bário e os demais elementos ( $\mathrm{Ca}, \mathrm{Mg}, \mathrm{Cu}, \mathrm{Fe}, \mathrm{Mn}$ e $\mathrm{Zn}$ ) por espectrofotometria de absorção atômica (Malavolta et al., 1997). 


\subsubsection{Produção de grãos}

Após serem coletadas, as vagens foram abertas manualmente, contando-se o número de vagens com $0,1,2$ e 3 grãos e o número de grãos chochos, sendo também calculadas suas respectivas percentagens. Após a contagem, as vagens vazias foram reservadas para posterior determinação da massa de matéria seca.

Os grãos foram acondicionados em sacos de papel, contados e pesados, sendo retirada uma amostra de grãos de cada saquinho para a determinação do grau de umidade, através do método de estufa a $105 \pm 3^{\circ} \mathrm{C}$ durante $24 \mathrm{~h}$, segundo as instruções das Regras para Análises de Sementes (Brasil, 1992), para posterior correção do peso da produção obtido, a 13\% de água.

\subsubsection{Massa de 100 grãos}

A massa de 100 grãos foi calculada pela razão entre a massa obtida (corrigida para a umidade de $13 \%$ ) e o número total de grãos por parcela, multiplicado por 100 , ou seja:

$$
\text { Massa de } 100 \text { grãos }=\frac{\text { Massa da amostra } \times 100}{n^{0} \text { total de grãos }}
$$

\subsubsection{Massa da matéria seca}

Foi determinada a massa da matéria seca das diferentes partes da planta: raizes, folhas, ramos e vagens sem grãos. O material foi levado à estufa com ventilação forçada e temperatura de $70^{\circ} \mathrm{C}$ até atingir massa constante. Em 
seguida foi obtida a massa da matéria seca mediante pesagem em balança com precisão de $0,001 \mathrm{~g}$.

\subsubsection{6 Índice de colheita}

$O$ índice de colheita (IC) pode ser considerado como quociente freqüentemente usado para medir a eficiência de conversão de produtos sintetizados em material de importância econômica (Pereira \& Machado, 1987). Em relação a uma cultura madura esse índice pode ser definido como a razão entre a massa da matéria seca da fração econômica produzida (no caso, grão) chamada de produtividade econômica (PE) e a fitomassa seca total colhida (massa seca de raízes, caule, folhas, vagens e grãos) chamada de produtividade biológica (PB). O IC foi obtido pela fórmula:

$$
\text { I.C. }=\frac{P E \times 100}{P B}
$$

\subsubsection{Análise química dos grãos}

Foi adotado para a análise química dos grãos o mesmo procedimento descrito no item 3.1.6.2.

\subsubsection{Análise de solo}

As análises foram realizadas no Laboratório de Análises Químicas de Solo do Departamento de Solos e Nutrição de Plantas da USP/ESALQ, seguindo a metodologia descrita por Raij \& Quaggio (1983), para análise de rotina ( $\mathrm{pH}_{\mathrm{CaCl}}, \mathrm{P}, \mathrm{K}, \mathrm{Ca}, \mathrm{Mg}, \mathrm{H}+\mathrm{Al}$ ). O enxofre $\left(\mathrm{S}^{-\mathrm{SO}_{4}}{ }^{-2}\right.$ ) foi determinado 
segundo a metodologia proposta por Vitti (1989). Para o micronutrientes, utilizaram-se as seguintes metodologias: método de água quente para o elemento B (Berger \& Truog, 1939) e método DTPA para $\mathrm{Cu}, \mathrm{Fe}, \mathrm{Mn}$ e $\mathrm{Zn}$ (Lindsay \& Morvell, 1978). A partir da obtenção desses atributos químicos do solo, foram calculadas a soma de bases (SB), a capacidade de troca catiônica (T) e os valores de saturação por bases (V\%).

\subsubsection{Procedimento estatístico}

Os experimentos em casa de vegetação foram analisados estatisticamente utilizando-se delineamento em blocos casualizados, com quatro repetições, segundo esquemas apresentados nas Tabelas 8, 9, 10 e 11.

Para comparação múltipla de médias foi utilizado o teste de Tukey, a $5 \%$ de probabilidade. Os cálculos estatísticos foram realizados através do Sistema de Análise Estatística - SANEST (Zonta \& Machado, 1984).

Tabela 8. Esquema de análise da variância dos resultados de produção de grãos, número de vagens com 0, 1, 2 e 3 grãos, número de vagens total, número e percentagem de grãos chochos, análise química dos grãos, índice de colheita, massa de 100 grãos, massa da matéria seca e análise de solo (épocas 1 e 2).

\begin{tabular}{cc}
\hline Causa da variação & Grau de Liberdade \\
\hline Tratamentos & 9 \\
Blocos & 3 \\
Resíduo & 27 \\
\hline Total & 39 \\
\hline
\end{tabular}


Tabela 9. Esquema de análise da variância dos resultados de percentagem de vagens com 0, 1, 2 e 3 grãos (Épocas 1 e 2).

\begin{tabular}{cc}
\hline Causa da variação & Grau de Liberdade \\
\hline Tratamentos & 9 \\
Percentagem & 3 \\
Tratamentos x Percentagem & 27 \\
Bloco & 3 \\
Resíduo & 117 \\
\hline Total & 159 \\
\hline
\end{tabular}

Tabela 10 Esquema de análise da variância dos resultados de diagnose foliar e teor de clorofila (Época 1).

\begin{tabular}{cc}
\hline Causa da variação & Grau de Liberdade \\
\hline Tratamentos & 9 \\
Amostragens & 1 \\
Tratamentos x Amostragens & 9 \\
Bloco & 3 \\
Resíduo & 57 \\
\hline Total & 79 \\
\hline
\end{tabular}

Tabela 11. Esquema de análise da variância dos resultados de diagnose foliare teor de clorofila (época 2).

\begin{tabular}{cc}
\hline Causa da variação & Grau de Liberdade \\
\hline Tratamentos & 9 \\
Amostragens & 2 \\
Tratamentos x Amostragens & 18 \\
Bloco & 3 \\
Resíduo & 87 \\
\hline Total & 119 \\
\hline
\end{tabular}

Na época 1, os dados provenientes do número de vagens com 0, 1, 2 e 3 grãos, número de vagens total e número de grãos chochos foram 
transformados em $\sqrt{x}$, enquanto que a percentagem de grãos chochos em $\operatorname{arc} \operatorname{sen} \sqrt{x / 100}$, Na época 2 , com exceção dos resultados de número de vagens com 0 grão, que foram transformados em $\sqrt{x+1}$, adotou-se o mesmo procedimento utilizado na época 1 , para esses parâmetros.

\subsection{Experimento de campo}

\subsubsection{Local e período de experimentação}

O experimento de campo foi conduzido do final do mês de novembro de 1998 (semeadura) até meados do mês de março de 1999 (colheita), em área de produção comercial de soja (sistema de plantio direto) na região do cerrado, localizada no município de Uberaba (MG), situado a $19^{\circ} 45^{\prime}$ de latitude Sul, $47^{\circ}$ $55^{\prime}$ de longitude Oeste e $759 \mathrm{~m}$ de altitude, onde a ocorrência de deficiência de manganês vinha sendo constatada.

\subsubsection{Caracterização da área experimental}

O clima da região, baseado na classificação internacional de Köeppen, é do tipo Aw, ou seja, tropical chuvoso (clima de savana), megatérmico com inverno seco sendo que a temperatura do mês mais frio é superior a $18^{\circ} \mathrm{C} \mathrm{e} \mathrm{a}$ precipitação do mês mais seco inferior a $60 \mathrm{~mm}$ (Embrapa, 1982).

O solo foi caracterizado como Latossolo Vermelho Amarelo distrófico muito argiloso, apresentando topografia plana e condições de boa drenagem. Suas características físicas e químicas foram determinadas no Laboratório de Análises Químicas de Solo do Departamento de Solos e Nutrição de Plantas da USP/ESALQ e estão apresentadas nas Tabelas 12, 13 e 14 respectivamente. 
Tabela 12. Resultado da análise granulométrica do Latossolo Vermelho Amarelo distrófico muito argiloso, da área experimental no município de Uberaba (MG), em três profundidades.

\begin{tabular}{cccc}
\hline $\begin{array}{c}\text { Profundidade } \\
\mathrm{cm}\end{array}$ & Areia & $\begin{array}{c}\text { Silte } \\
\mathrm{g} \mathrm{kg}^{-1} \ldots \ldots \ldots \ldots \ldots \ldots \ldots \ldots \ldots \ldots \ldots \ldots \ldots \ldots \ldots \ldots \ldots \ldots \ldots \ldots \ldots \ldots \ldots \ldots \ldots \ldots \ldots \ldots \ldots \ldots \ldots\end{array}$ \\
\hline $00-10$ & 130 & 160 & Argila \\
$10-20$ & 150 & 90 & 760 \\
$20-40$ & 100 & 70 & 860 \\
\hline
\end{tabular}

Tabela 13. Resultados das análises químicas do Latossolo Vermelho Amarelo distrófico muito argiloso, da área experimental no município de Uberaba (MG), em três profundidades.

\begin{tabular}{cccccccccccccc}
\hline $\begin{array}{c}\text { Prof. } \\
\mathrm{cm}\end{array}$ & $\mathrm{pH}$ & $\mathrm{MO}$ & $\mathrm{P}^{1}$ & $\mathrm{~S}_{-\mathrm{SO}_{4}{ }^{2}}$ & $\mathrm{~K}$ & $\mathrm{Ca}$ & $\mathrm{Mg}$ & $\mathrm{Al}$ & $\mathrm{H}+\mathrm{Al}$ & $\mathrm{SB}$ & $\mathrm{T}$ & $\mathrm{V}$ \\
\hline $00-10$ & 5,8 & 32 & 32 & 13 & 0,9 & 39 & 19 & 0 & 25 & 58,9 & 83,9 & 70 \\
$10-20$ & 5,3 & 33 & 7 & 9 & 0,9 & 20 & 14 & 0 & 25 & 34,9 & 59,9 & 58 \\
$20-40$ & 4,4 & 21 & 2 & 4 & 0,5 & 4 & 2 & 0 & 47 & 6,5 & 53,5 & 12 \\
\hline
\end{tabular}

Resina; ${ }^{2} \mathrm{NH}_{4}$ OAC 0,5N em HOAC 0,25N (10ml TFSA / 25ml)

Tabela 14. Resultados das análises químicas de micronutrientes do Latossolo Vermelho Amarelo distrófico muito argiloso, da área experimental no município de Uberaba (MG), em três profundidades.

\begin{tabular}{|c|c|c|c|c|c|}
\hline $\begin{array}{c}\text { Profundidade } \\
\mathrm{cm}\end{array}$ & $\bar{B}$ & $\overline{\mathrm{Cu}^{2}}$ & $\begin{array}{c}\mathrm{Fe}^{2} \\
\mathrm{mg} \mathrm{dm}^{-3}\end{array}$ & $\overline{\mathrm{Mn}^{2}}$ & $\overline{\mathrm{Zn}^{2}}$ \\
\hline $00-10$ & 0,43 & 1,3 & 36,2 & 1,6 & 4,6 \\
\hline $10-20$ & 0,05 & 0,7 & 22,4 & 0,2 & 1,6 \\
\hline $20-40$ & 0,15 & 0,4 & 10,0 & 0,2 & 0,2 \\
\hline
\end{tabular}

- Extrator $\mathrm{BaCl}_{2} .2 \mathrm{H}_{2} \mathrm{O} 0,125 \%$ microondas (10ml TFSA / $20 \mathrm{ml} \mathrm{de} \mathrm{BaCl}_{2}$ 0,125ml);

${ }^{2}$ Extrator DTPA 
A precipitação durante o periodo de condução do experimento foi registrada e encontra-se na Tabela 15.

Tabela 15. Precipitação $(\mathrm{mm})$ registrada na área experimental durante $\circ$ período de condução do experimento.

\begin{tabular}{|c|c|c|c|c|c|c|c|}
\hline \multirow{3}{*}{ Dia } & \multicolumn{3}{|c|}{1998} & \multicolumn{4}{|c|}{1999} \\
\hline & \multicolumn{7}{|c|}{ Mes } \\
\hline & Out & Nov & Dez & Jan & Fev & Mar & $\mathrm{Abr}$ \\
\hline 1 & 5 & & 27 & 30 & 6 & 14 & \\
\hline 2 & & & & 30 & 1 & & \\
\hline 3 & & & & 25 & & 20 & \\
\hline 4 & & & & 60 & & & \\
\hline 5 & 3,5 & & & 37 & & 30 & \\
\hline 6 & & & & 40 & 3 & 30 & 88 \\
\hline 7 & & 63 & 38 & & & 31 & \\
\hline 8 & 4 & & & & & & \\
\hline 9 & & 24 & & & & & \\
\hline 10 & 2,5 & & & & & 13 & \\
\hline 11 & & & 35 & & 7 & & \\
\hline 12 & & 17 & & & & & \\
\hline $\begin{array}{l}13 \\
14\end{array}$ & 22 & 18 & & & 5 & & 5 \\
\hline 15 & 10 & & 35 & & & & \\
\hline 16 & 50 & & & 57 & & & \\
\hline 17 & & & 13 & & & 9 & \\
\hline 18 & & & & & 10 & & \\
\hline 19 & & & & & & & \\
\hline 20 & & & & & & & \\
\hline 21 & & & 13 & & 65 & & \\
\hline 22 & & & 6 & & 3 & & \\
\hline 23 & & & & & 4 & 30 & \\
\hline 24 & & 8 & 10 & & & 5 & \\
\hline 25 & & & 30 & & 17 & 6 & \\
\hline 26 & 6 & 10 & 30 & & & & \\
\hline 27 & & & 20 & & & 21 & \\
\hline 28 & 24 & 10 & 20 & & 25 & & \\
\hline 29 & 6 & & & 46 & & 13 & \\
\hline 30 & 6,5 & & 30 & 23 & & & \\
\hline 31 & & & & & & & \\
\hline TOTAL & 139,5 & 150 & 307 & 348 & 146 & 222 & 93 \\
\hline
\end{tabular}




\subsubsection{Cultivar}

O cultivar de soja utilizado foi a MG/BR-48 (GARIMPO RCH), indicada para cultivo comercial no Estado de Minas Gerais, cujas principais características já foram descritas no item 3.1.3.

\subsubsection{Instalação do experimento}

\subsubsection{Preparo da área, semeadura e adubação}

A área em que foi instalado o experimento vinha sendo cultivada com soja durante os três anos anteriores pelo sistema de plantio direto. Antes da semeadura, foi realizada uma aplicação de herbicida de pós-emergência (glifosato) objetivando o controle das plantas daninhas presentes na área.

As sementes utilizadas foram as mesmas dos experimentos de casa de vegetação as quais foram tratadas com fungicida Tegram (Thiabendazole + Thiram) e com inoculante (Bradyrhizobium japonicum) em meio turfoso esterilizado na dose de $5 \mathrm{~g} \mathrm{~kg}^{-1}$ de semente.

A semeadura foi realizada mecanicamente, em linhas espaçadas de $0,5 \mathrm{~m}$, objetivando-se população aproximada de 330.000 plantas $\mathrm{ha}^{-1}$ (stand de 16,5 plantas $\mathrm{m}^{-1}$ ).

Juntamente com a semeadura foi realizada adubação de plantio de manutenção, fornecendo $6 \mathrm{~kg} \mathrm{ha}^{-1}$ de $\mathrm{N}, 66 \mathrm{~kg} \mathrm{ha}^{-1}$ de $\mathrm{P}_{2} \mathrm{O}_{5}$ e $60 \mathrm{~kg} \mathrm{ha}^{-1}$ de $\mathrm{K}_{2} \mathrm{O}$. Para isso foram utilizados no plantio, $330 \mathrm{~kg} \mathrm{ha}^{-1}$ da fórmula 02-20-18. 


\subsubsection{Delineamento experimental}

Os experimentos foram instalados segundo um delineamento experimental em blocos casualizados, com 9 tratamentos e 5 repetições totalizando 45 parcelas.

Cada parcela era constituida de 12 linhas de 6,0 m de comprimento (36 $\mathrm{m}^{2}$ de área total). As 10 linhas centrais foram consideradas como úteis descontando-se $1 \mathrm{~m}$ de cada linha como bordadura (Figura 3). Assim a área útil da parcela foi de $25 \mathrm{~m}^{2}$.

$6,0 \mathrm{~m}$

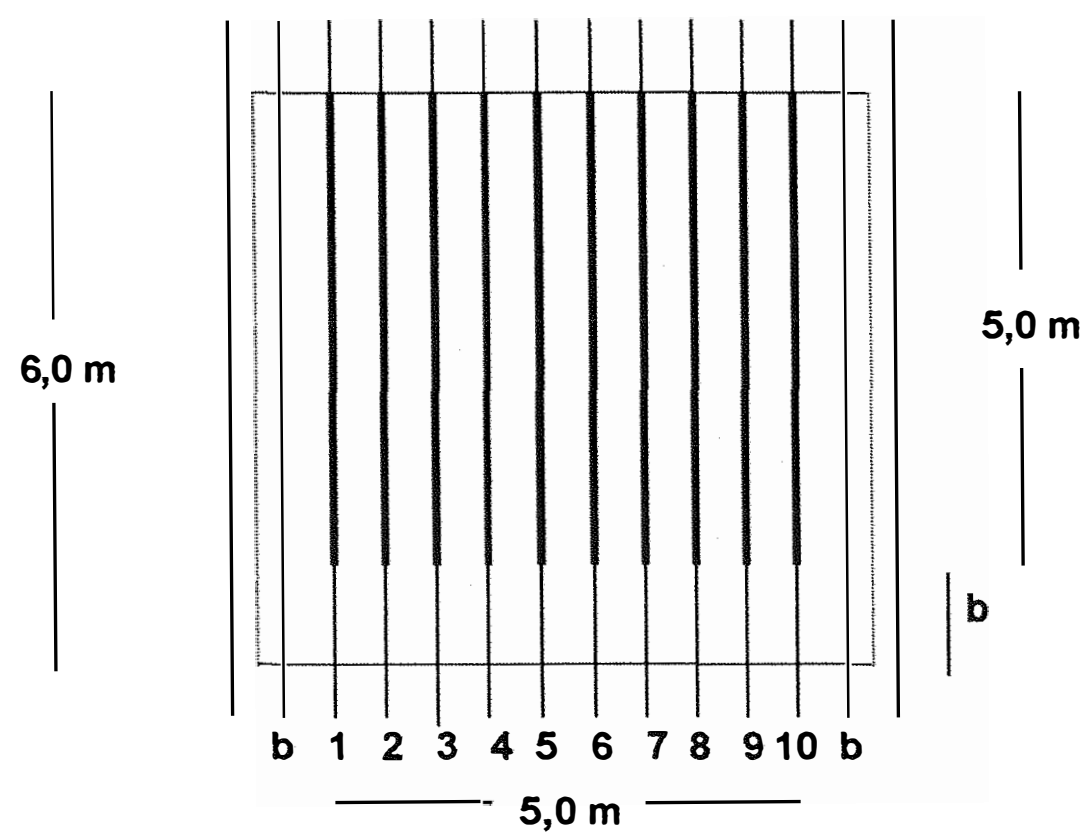

Figura 3. Esquema da parcela do experimento. Área total $36 \mathrm{~m}^{2} \mathrm{e}$ área útil de $25 \mathrm{~m}^{2}$ (em negrito). Linhas de 1-10 são úteis e "b" são bordaduras. Foram colhidas as linhas úteis 4,5 e 6. 


\subsubsection{Tratamentos}

Os tratamentos constaram de fontes de manganês aplicadas via solo e foliar (Tabela 16). Estas fontes já foram descritas no item 3.1.4.4.

Tabela 16. Esquema de tratamentos, produtos, doses e via de aplicação, no experimento de campo.

\begin{tabular}{clcc}
\hline Tratamento & \multicolumn{1}{c}{$\begin{array}{c}\text { Fonte de } \\
\text { manganês }\end{array}$} & Via de Aplicação & $\begin{array}{c}\text { Dose de manganês } \\
(\mathrm{g} \mathrm{ha})\end{array}$ \\
\hline 1 & Testemunha & - & - \\
2 & $\mathrm{MnSO}_{4} 4 \mathrm{H}_{2} \mathrm{O}$ & foliar & $350^{*}$ \\
3 & $\mathrm{MnSO}_{4} .4 \mathrm{H}_{2} \mathrm{O}$ & foliar & $200^{*}$ \\
4 & Quelado $\mathrm{Cl}^{-}$ & foliar & $200^{*}$ \\
5 & Quelado $\mathrm{NO}_{3}^{-}$ & foliar & $200^{*}$ \\
6 & Quelado $\mathrm{SO}_{4}^{-2}$ & foliar & $200^{*}$ \\
7 & Mancozeb & foliar & $200^{*}$ \\
8 & MnSO $4.4 \mathrm{H}_{2} \mathrm{O}$ & solo & 4000 \\
9 & Oxi-sulfato Mn & solo & 4000 \\
\hline *Dose por aplicação (foram realizadas duas aplicaçōes).
\end{tabular}

\subsubsection{Condução dos experimentos}

\subsubsection{Aplicação dos tratamentos via solo}

Os tratamentos via solo ( 8 e 9) foram aplicados imediatamente após o início da emergência das plântulas. A aplicação foi feita na superfície do solo, junto e paralelamente às linhas de plantio. Para permitir precisão nas doses, o tratamento com sulfato de manganês foi aplicado via solução $\left(8 \mathrm{~g} \mathrm{~L}^{-1}\right)$ e para o 
tratamento com oxi-sulfato de manganês foi feita uma mistura do produto com areia fina de modo a obter uma concentração de $20 \mathrm{~g} \mathrm{~kg}^{-1}$. Nos dois casos a aplicação no campo forneceu a dose de manganês equivalente a $4000 \mathrm{~g} \mathrm{ha}^{-1}$.

\subsubsection{Controle de mato e pragas}

O controle de mato foi feito através da aplicação inicial da mistura de: glifosato + metolachlor + imazaquin, com a finalidade de dessecação; posteriomente, em pós-emergência, foi realizada aplicação de oxasulfuron.

O controle de lagartas e/ou percevejos foi efetuado, em três aplicações, utilizando-se: lufenuron $\left(7,5 \mathrm{~g}\right.$ i.a. $\left.\mathrm{ha}^{-1}\right)$, monocrotofós $(150 \mathrm{~g}$ i.a. ha ${ }^{-1}$ ) e profenofós ( $80 \mathrm{~g}$ i.a. $\left.\mathrm{ha}^{-1}\right)$, respectivamente.

\subsubsection{Amostragem de folhas}

Foram realizadas três amostragens de folhas: a primeira quando a maioria das plantas estava no estádio vegetativo $V_{4}$; a segunda, quando a maioria das plantas estava no estádio reprodutivo $R_{1}$ (ambas precedendo a aplicação foliar) e, a terceira (20 dias após), quando a maioria das plantas estava no estádio $R_{4}$. Em cada uma das amostragens foi coletada a terceira folha desenvolvida com peciolo à partir do ápice da haste principal de 10 plantas por parcela.

\subsubsection{Aplicação dos tratamentos via foliar}

Foram feitas duas aplicações dos tratamentos via foliar $(2,3,4,5,6$ e 7): a primeira, quando a maioria das plantas estava no estádio $V_{4} e$, a segunda, 
quando a maioria das plantas estava no estádio $R_{1}$. Esta aplicação foi realizada com pulverizador costal, sendo que o volume de solução aplicado foi de $40 \mathrm{~mL}$ $\mathrm{m}^{-2}\left(400 \mathrm{~L} \mathrm{ha}^{-1}\right)$.

\subsubsection{Amostragem de solo}

No dia da coleta do experimento, foi realizada uma amostragem de solo, retirando-se com auxílio de uma sonda dez sub-amostras, dentro da área útil de cada parcela, nas profundidades de 0 a $10 \mathrm{~cm}$ e 10 a $20 \mathrm{~cm}$, formandose assim uma amostra composta por parcela.

\subsubsection{Coleta do experimento}

No final do ciclo da cultura, fase $R_{8}$ (111 dias após a semeadura), as plantas das três linhas centrais (ruas 4,5 e 6 ) foram cortadas, com tesoura de poda manual, e acondicionadas em sacos de juta devidamente identificados, equivalendo à produção de $15 \mathrm{~m}$ de linha $\left(7,5 \mathrm{~m}^{2}\right)$. Em seguida, com o objetivo de minimizar possiveis danos mecânicos aos grãos, foi realizada a debulha manual do material colhido e, os grãos limpos, foram acondicionados em sacos de papel.

\subsubsection{Avaliações do experimento}

\subsubsection{Teor de clorofila}

Juntamente com a amostragem de folhas (descrita anteriormente), foi realizada a avaliação no teor de clorofila, conforme descrito no item 3.1.6.1. 


\subsubsection{Diagnose foliar}

Para a realização da diagnose foliar, foi adotado o mesmo procedimento descrito no item 3.1.6.2.

\subsubsection{Altura final de planta}

Das três linhas a serem coletadas, foram tomadas aleatoriamente 10 plantas para a obtenção de suas alturas, medindo-se as distâncias entre o colo da planta e o ápice da mesma.

\subsubsection{Produção de grãos}

Os grãos limpos foram pesados, sendo então retiradas duas amostras por parcela com o objetivo de determinar o grau de umidade dos mesmos (conforme descrito no item 3.1.6.4), para posterior correção do peso da produção obtido, a $13 \%$ de água.

Para a realização das diversas análises, a produção por parcela foi homogeneizada e reduzida adequadamente, através de divisor mecânico cônico (tipo Boerner), para a obtenção das amostras de trabalho, segundo as instruções das Regras para Análises de Sementes (Brasil, 1992).

\subsubsection{Análise química dos grãos}

Para esta determinação foi utilizado o mesmo procedimento descrito no item 3.1.6.2. 


\subsubsection{Análise de solo}

Foi adotada a mesma metodologia descrita no item 3.1.6.9.

\subsubsection{Determinação do teor de óleo e proteína.}

Inicialmente, foi efetuada a moagem das amostras de sementes de soja, utilizando-se de um moinho de Wiley, no Depto. de Solos e Nutrição de Plantas da USP/ESALQ. Em seguida, as amostras foram passadas em peneiras de diâmetro $0,05 \mathrm{~mm}$, sendo posteriormente enviadas a EmbrapaSoja, em Londrina, PR, para realização das análises de óleo e proteína.

O teor de óleo foi determinado pelo método de Soxlet, com hexano como solvente, em amostras de um grama, e as análises de proteína foram feitas em triplicata em amostras de $0,1 \mathrm{~g}$ de matéria seca, pelo método de Kjeldahl tendo o sulfato de cobre como catalisador.

\subsubsection{Avaliação da qualidade das sementes}

A avaliação da qualidade das sementes foi efetuada no Laboratório de Análise de Sementes do Departamento de Produção Vegetal da USP/ESALQ. Para tanto, foram realizados os seguintes testes, descritos a seguir.

\subsection{Massa de mil sementes}

A partir das amostras de trabalho, foram contadas ao acaso e manualmente, oito repetições de 100 sementes, por tratamento, e em seguida pesadas cada uma das repetições com precisão de $0,01 \mathrm{~g}$. Para a obtenção da 
massa de 1000 sementes foram adotados os procedimentos descritos pelas Regras para Análise de Sementes (Brasil, 1992).

\subsection{Determinação do grau de umidade}

Foi avaliado em estufa a $105 \pm 3^{\circ} \mathrm{C}$, durante 24 horas, utilizando-se duas amostras por parcela, segundo as instruções das Regras para Análises de Sementes (Brasil, 1992); os resultados foram expressos em percentagem média para cada tratamento.

\subsection{Germinação}

A instalação do teste de germinação foi feita em rolos de papel (tipo Germitest), previamente umedecidos com quantidade de água equivalente a 2,5 vezes o peso do papel. Foram utilizadas cinco repetições de 50 sementes para cada tratamento, semeadas e mantidas à temperatura constante de $25^{\circ} \mathrm{C}$, em câmara de germinação. As contagens foram efetuadas aos 5 e 8 dias após a semeadura seguindo-se os critérios estabelecidos pelas Regras para Análises de Sementes (Brasil, 1992). Os resultados foram expressos em percentagem média.

\subsection{Teste de Vigor - Envelhecimento acelerado}

Este teste foi conduzido com a utilização de caixas plásticas (11,0 x $11,0 \times 3,5 \mathrm{~cm})$, com uma camada uniforme de sementes sobre a superficie da tela que isola as sementes da água ( $40 \mathrm{~mL}$ ), mantidas por $48 \mathrm{~h}$ em incubadora previamente regulada à temperatura de $41^{\circ} \mathrm{C}$ (Marcos Filho, 1994). 
Decorrido o período de envelhecimento, cinco amostras de 50 sementes por tratamento foram colocadas para germinar conforme descrito no item 3.2.6.8.3. A avaliação foi realizada aos 5 dias após a semeadura, obtendose a percentagem de plântulas normais.

\subsection{Teste de Vigor - Condutividade elétrica}

Para avaliação da condutividade elétrica na solução de embebição das sementes, foram usadas cinco repetições de 50 sementes para cada tratamento, sendo pesadas com precisão de $0,01 \mathrm{~g}$ e colocadas para embeber em copos plásticos (capacidade de $200 \mathrm{~mL}$ ) contendo $75 \mathrm{~mL}$ de água destilada, durante 24 horas, à temperatura de $25^{\circ} \mathrm{C}$ (Vieira, 1994). Em seguida, procedeuse à leitura da condutividade elétrica em condutivímetro DIGIMED DM-31 e os valores médios obtidos para cada tratamento foram expressos em $\mu \mathrm{mho} \mathrm{cm}^{-1} \mathrm{~g}^{-1}$ de semente.

\subsubsection{Procedimento estatístico}

O experimento de campo foi analisado estatisticamente utilizando-se delineamento em blocos casualizados, com cinco repetições, segundo esquemas apresentados nas Tabelas 17, 18 e 19.

Os resultados provenientes dos testes de germinação e envelhecimento acelerado foram transformados em arc sen $\sqrt{x / 100}$. Por outro lado, os resultados referentes ao grau de umidade das sementes não foram analisados estatisticamente; sua interpretação foi relacionada apenas aos aspectos biológicos. 
Tabela 17. Esquema de análise de variância dos resultados de produção de grãos, altura final de planta, análise química dos grãos, teor de óleo e proteína, massa de mil sementes, germinação, envelhecimento acelerado e condutividade elétrica.

\begin{tabular}{cc}
\hline Causas da variação & Grau de Liberdade \\
\hline Tratamentos & 8 \\
Blocos & 4 \\
Resíduo & 32 \\
\hline Total & 44 \\
\hline
\end{tabular}

Tabela 18. Esquema de análise de variância dos resultados de diagnose foliar e teor de clorofila.

\begin{tabular}{cc}
\hline Causa da variação & Grau de Liberdade \\
\hline Tratamentos & 8 \\
Amostragens & 2 \\
Tratamentos x Amostragens & 16 \\
Bloco & 4 \\
Residuo & 104 \\
\hline Total & 134 \\
\hline
\end{tabular}

Tabela 19. Esquema de análise de variância dos resultados de análise de solo.

\begin{tabular}{cc}
\hline Causa da variação & Grau de Liberdade \\
\hline Tratamentos & 8 \\
Profundidades & 2 \\
Tratamentos $\times$ Profundidades & 16 \\
Bloco & 4 \\
Resíduo & 104 \\
\hline Total & 134 \\
\hline
\end{tabular}


Para comparação múltipla de médias foi utilizado o teste de Tukey, a $5 \%$ de probabilidade. Os cálculos estatísticos foram realizados através do Sistema de Análise Estatística - SANEST (Zonta \& Machado, 1984). 


\section{RESULTADOS E DISCUSSÃO}

\subsection{Experimento em casa de vegetação (Época 1)}

\subsubsection{Teores foliares de nutrientes}

Os teores foliares de macronutrientes nos estádios fenológicos R1 e R4 estão apresentados nas Tabelas 20 e 21, respectivamente.

Nas duas épocas de amostragem estudadas, não foram encontradas diferenças entre os níveis foliares de macronutrientes, em função dos tratamentos.

Pode-se observar que os níveis de N, P e S no estádio R1 (Tabela 20) apresentaram-se abaixo daqueles considerados como adequados para 0 referido estádio fenológico, sem contudo atingir o nível de deficiência. Já os teores foliares de $\mathrm{K}, \mathrm{Ca}$ e $\mathrm{Mg}$ encontraram-se dentro dos limites de suficiência para a cultura (Ambrosano et al., 1996; Malavolta et al., 1997 e Embrapa, 1998).

Todavia, tanto os teores foliares obtidos de N, P e S, quanto os de $\mathrm{K}$, $\mathrm{Ca}$ e $\mathrm{Mg}$, estão coerentes com as faixas de teores (em $\mathrm{g} \mathrm{kg}^{-1}$ ) verificadas por vários autores, em amostragens realizadas no mesmo estádio fenológico: 27,2 a 42,4 para N; 1,6 a 3,1 para $\mathrm{P} ; 15,1$ a 27,7 para $\mathrm{K}$; 6,7 a 16,9 para Ca; 2,9 a 5,6 para Mg e 1,1 a 3,1 para S (Mascarenhas et al., 1980; Ramos et al.,1989; Tanaka et al., 1992b; Lazarini, 1995 ; Mascarenhas et al.,1996). 


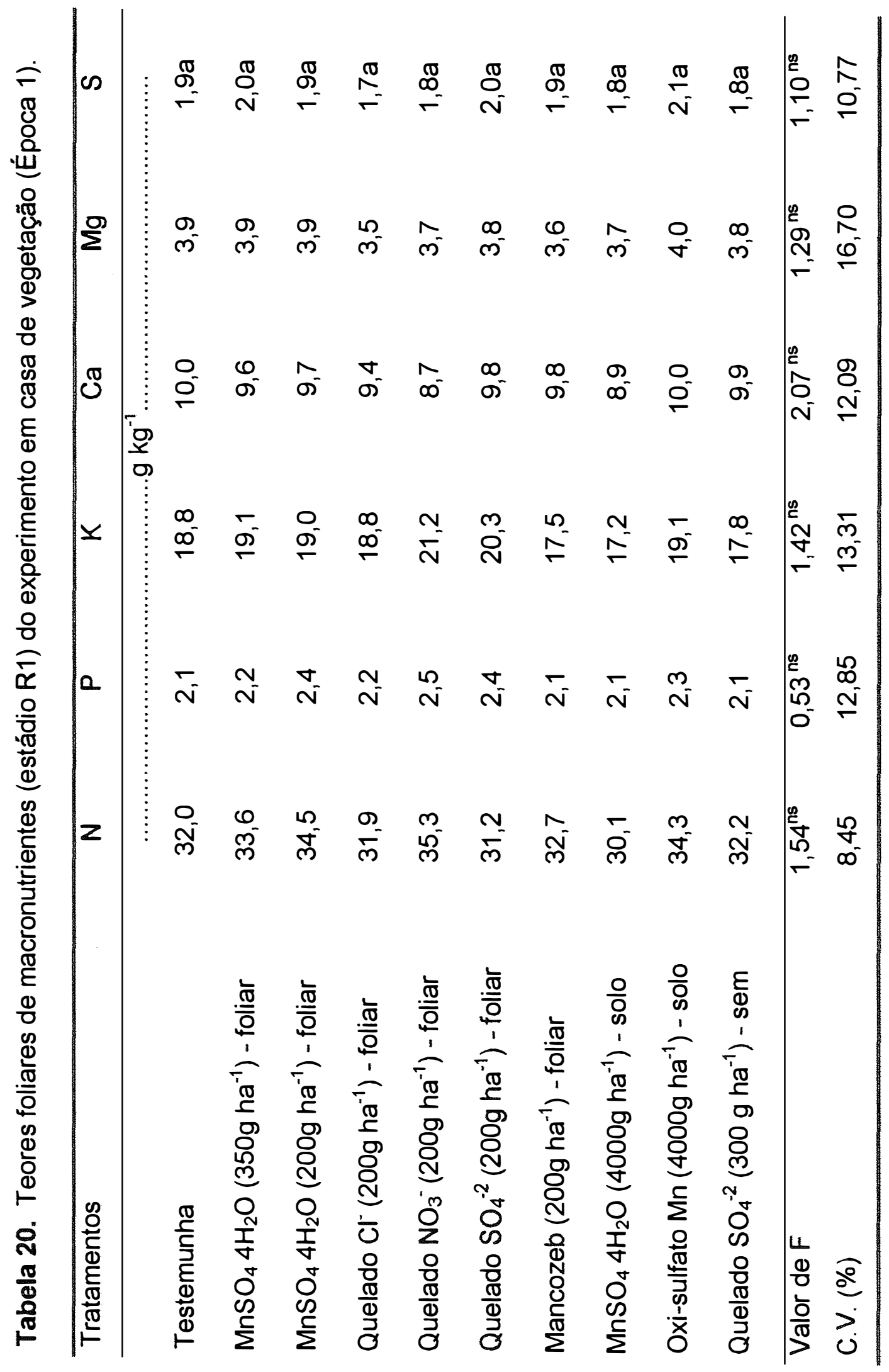




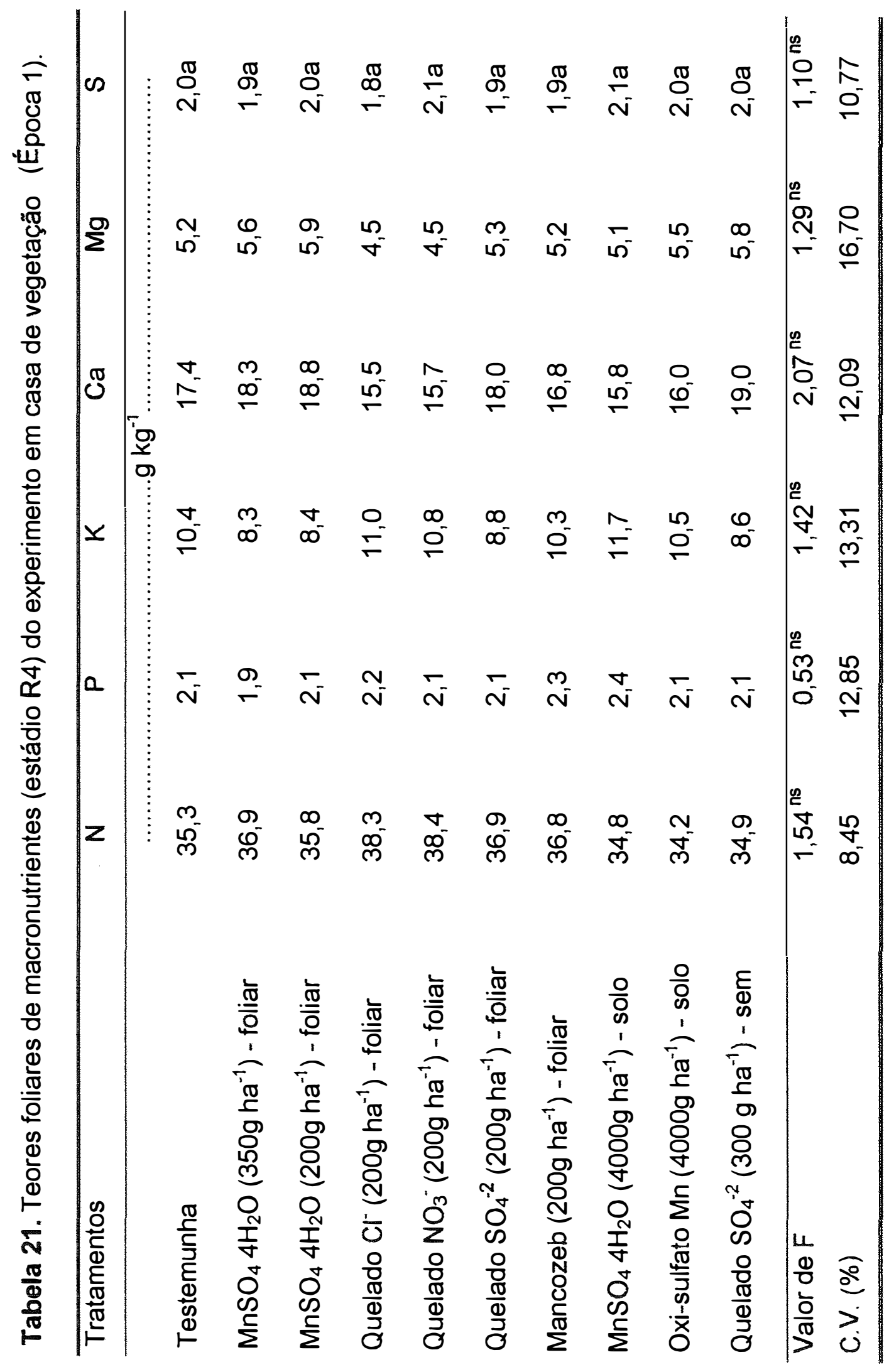


Em relação à época de amostragem (Tabela 22), observou-se que para nitrogênio, cálcio e magnésio, houve aumento na média dos níveis foliares encontrados no estádio R4, em comparação ao estádio R1. Os níveis de fósforo e enxofre não sofreram variação, enquanto que para o potássio foi verificada redução.

O estádio R4 marca o início do período mais crítico de desenvolvimento da planta quanto à determinação do rendimento em grãos, sendo uma fase muito suscetivel a deficiências nutricionais, as quais, se ocorrerem, poderão afetar diretamente a produção. É um estádio marcado pelo rápido e constante acúmulo de matéria seca pelas vagens (Ritchie et al., 1997). Assim, infere-se que, neste estádio, deve ser verificada alta demanda de nutrientes das folhas para as regiōes de acúmulo (vagens), levando portanto a redução dos níveis foliares de nutrientes.

Tabela 22. Comparação entre médias dos teores foliares de macronutrientes, nos estádios R1 e R4, do experimento de casa de vegetação (Época 1).

\begin{tabular}{|c|c|c|c|c|c|c|}
\hline Estádio & $\bar{N}$ & $\bar{P}$ & $\overline{\mathrm{K}}$ & $\overline{\mathrm{Ca}}$ & $\mathrm{Mg}$ & $\bar{S}$ \\
\hline & \multicolumn{6}{|c|}{ 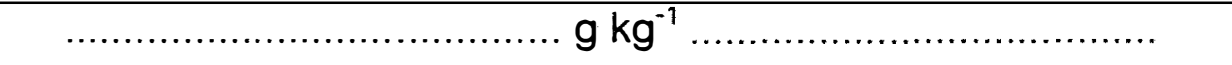 } \\
\hline R1 & $33,2 b^{1}$ & 2,2 & $18,8 a$ & $9,6 b$ & $3,76 b$ & 1,86 \\
\hline R4 & $36,2 a$ & 2,1 & $9,8 b$ & $17,1 \mathrm{a}$ & $5,25 a$ & 1,94 \\
\hline $\begin{array}{l}\text { Valor de F } \\
\text { C.V. (\%) }\end{array}$ & $\begin{array}{c}21,64^{\star \star} \\
8,45\end{array}$ & $\begin{array}{l}1,85^{\text {ns }} \\
12,84\end{array}$ & $\begin{array}{c}442,01^{\star \star} \\
13,31\end{array}$ & $\begin{array}{c}436,23^{\star \star} \\
12,09\end{array}$ & $\begin{array}{l}78,49^{\star \star} \\
16,70\end{array}$ & $\begin{array}{r}3,43^{\text {ns }} \\
10,77\end{array}$ \\
\hline
\end{tabular}

A nula ou baixa mobilidade do $\mathrm{Ca}$ e $\mathrm{S}$ pode explicar os resultados para estes nutrientes, pois esse fato reduziria a possibilidade de uma eficiente redistribuição das folhas para as vagens, mantendo ou elevando os níveis desses elementos nas folhas amostradas. Além disso, as condiçōes em que as plantas se desenvolveram podem não ter sido favoráveis para uma diminuição, 
ou mesmo interrupção, do suprimento desses nutrientes do solo para a planta. Este último fato pode inclusive, ter contribuido para o aumento e/ou manutenção dos niveis de $\mathrm{N}, \mathrm{P}$ e $\mathrm{Mg}$.

Outro fator verificado foi um possivel sinergismo entre $\mathrm{Ca}$, em relação ao demais nutrientes, e do $\mathrm{Mg}$ em relação ao $\mathrm{P}$. No primeiro caso, o ocorrido deve-se ao fato de que o $\mathrm{Ca}^{2+}$, em concentrações não muito elevadas, favorece a absorção de cátions e de ânions por seu papel na manutenção da integridade funcional do plasmalema. No segundo, o Mg aumentou (ou manteve alta) a absorção de P (Malavolta et al., 1997).

Por outro lado, o aumento da concentração foliar de Ca encontrado no estádio R4, em relação ao $\mathrm{R} 1$, pode ter permitido a ocorrência de inibição competitiva entre $\mathrm{Ca}^{2+} \mathrm{e} \mathrm{K}^{+}$, o que permite explicar a redução dos niveis foliares de K nesta fase.

Os teores foliares de $\mathrm{N}$ e $\mathrm{P}$, observados em R4, encontraram-se superiores e, o teor de K, inferior aos obtidos por Hanway \& Weber (1971). Os autores verificaram níveis foliares de $\mathbf{N}, \mathbf{P}, \mathrm{K}$, da ordem de 18 a 22; 1,0 a 1,7 e $12 \mathrm{~g} \mathrm{~kg}^{-1}$, respectivamente, na fase de maturidade fisiológica das sementes (estádio R7).

Com exceção do $\mathrm{N}$ e $\mathrm{Mg}$, os dados obtidos foram semelhantes aos verificados por Malavolta et al. (1980) que, trabalhando com solução nutritiva, encontraram niveis para $\mathrm{N}, \mathrm{P}, \mathrm{Ca}, \mathrm{Mg}$ e $\mathrm{S}$, respectivamente, de 8,0 e 12,5; 2,4 e 2,$5 ; 9,8$ e 13,1; 17,2 e 12,7; 3,7 e 2,3; 0,9 e 2,3 $\mathrm{g} \mathrm{kg}^{-1}$, no periodo de formação de vagens (R3-R4) para os cultivares Santa Rosa e UFV-1.

Entre os micronutrientes não foram verificadas diferenças em função dos tratamentos, no estádio R1 (Tabela 23). Entretanto, no estádio R4, encontraram-se diferenças entre os teores foliares de manganês (Tabela 24).

No estádio R1, pode-se observar que os teores de $\mathrm{B}, \mathrm{Fe}$ e $\mathrm{Zn}$ encontraram-se dentro dos limites considerados adequados, enquanto que $\mathrm{Cu} \mathrm{e}$ Mn apresentaram-se abaixo dos niveis de suficiência (Ambrosano et al., 1996, Malavolta et al., 1997 e Embrapa, 1998). 


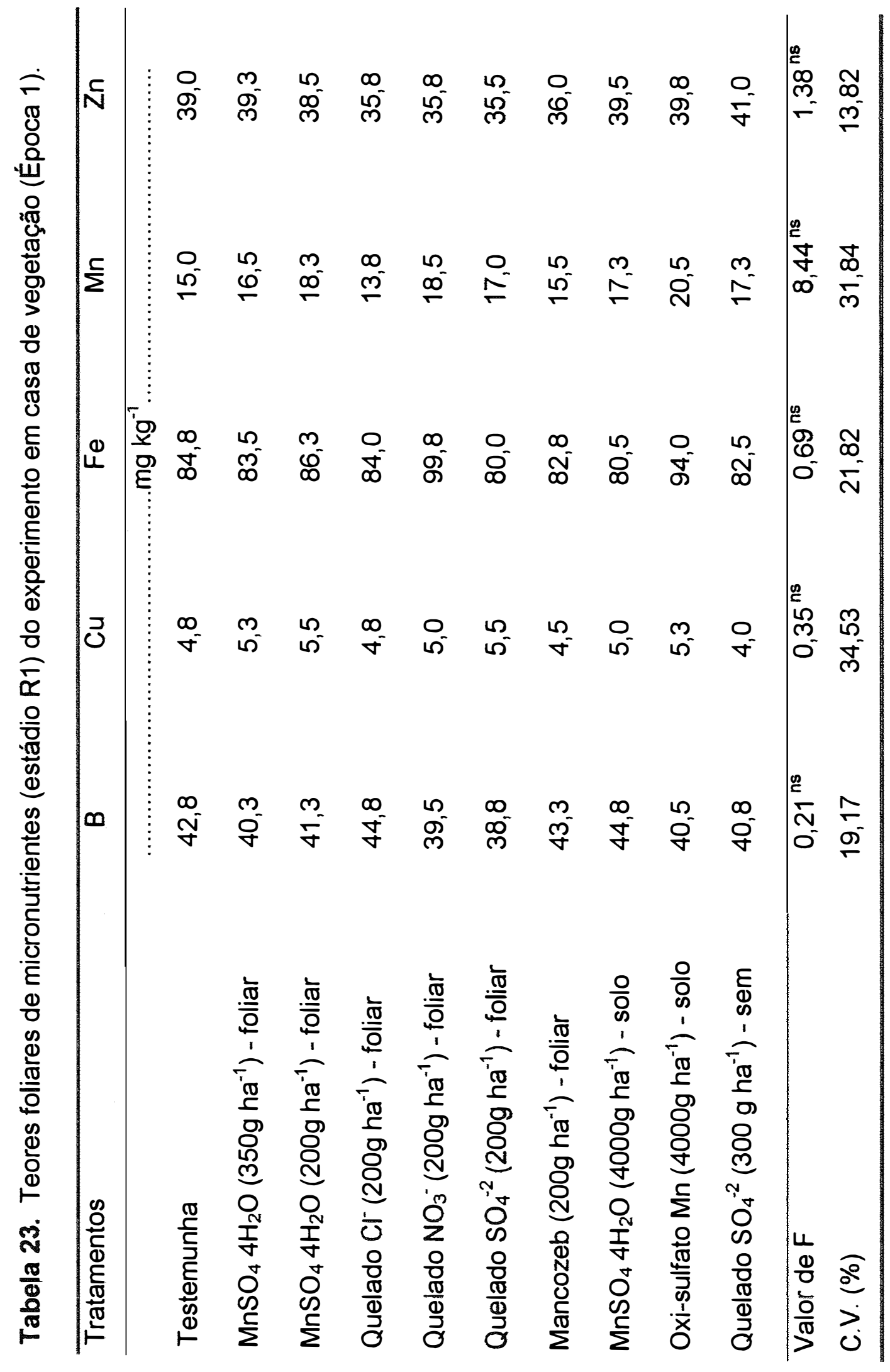




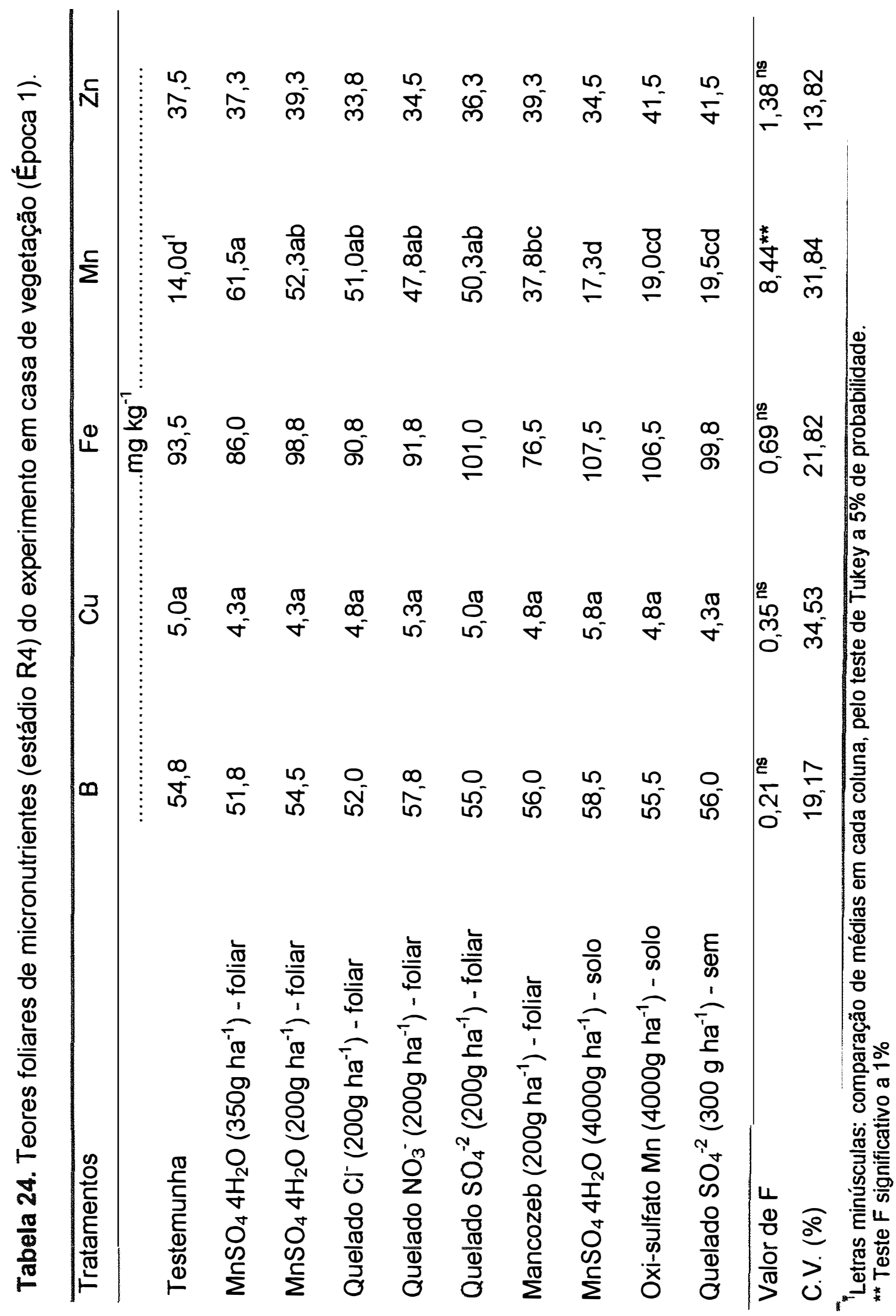


Os teores foliares de $\mathrm{B}, \mathrm{Fe}$ e $\mathrm{Zn}$ foram semelhantes às faixas de valores ( $\mathrm{mg} \mathrm{kg}^{-1}$ ) encontradas em diversos trabalhos: 27 a 53 para B; 83 a 97 para Fe e 18 a 52 para Zn (Mascarenhas et al.,1980; Galrão, 1991; Tanaka et al.,1992b; Lazarini, 1995).

Os teores foliares de cobre, embora considerados baixos pelo critério já mencionado, não diferiram em função dos tratamentos, sendo semelhantes aos encontrados por alguns autores.

Nesse sentido, Silva et al. (1986) encontraram teores foliares de cobre de $4,3 \mathrm{mg} \mathrm{kg}^{-1}$ para a testemunha (média de dois anos sem adubação com cobre). De acordo com o trabalho, mesmo as plantas que receberam aplicação de $510 \mathrm{~g} \mathrm{ha}^{-1}$ de cobre (via solo), na forma de sulfato, apresentaram níveis foliares de 6,1 $\mathrm{mg} \mathrm{kg}^{-1}$, ou seja, abaixo do nível crítico.

Resultados semelhantes foram obtidos por Galrão (1991), que encontrou níveis foliares de cobre na faixa de 1,0 a 2,8 e de 3,0 a $6,5 \mathrm{mg} \mathrm{kg}^{-1}$, respectivamente, para as plantas que não receberam cobre via solo e para as que receberam $2000 \mathrm{~g} \mathrm{ha}^{-1}$ do elemento na forma de sulfato.

Lazarini (1995) encontrou níveis foliares de cobre, na fase de florescimento da soja, que variaram de 4,8 até $10,3 \mathrm{mg} \mathrm{kg}^{-1}$, entre diferentes genótipos. Este autor observou que a época de semeadura causou interferência nos níveis foliares de cobre, obtendo valores médios de $3,4 \mathrm{mg} \mathrm{kg}^{-1}$ em semeaduras mais tardias.

Nota-se, portanto, que existem variações no teor de cobre influenciadas por fatores como genótipo e época de plantio. Além disso, nem sempre o fornecimento do elemento via solo resultou em teores foliares acima do nível crítico.

Para o manganês, os teores foliares encontrados no estádio R1 não diferiram entre si, apresentando-se em níveis considerados baixos. Este resultado mostra a baixa capacidade de fornecimento de manganês à planta encontrada no solo utilizado, revelando, portanto, condições favoráveis para a realização do presente experimento. 
A maioria das plantas apresentaram sintomas visuais de deficiência, em R1, como pode ser observado na Figura 4, confirmando a alta susceptibilidade deste cultivar à deficiência de manganês encontrada por Abreu et al. (1994).

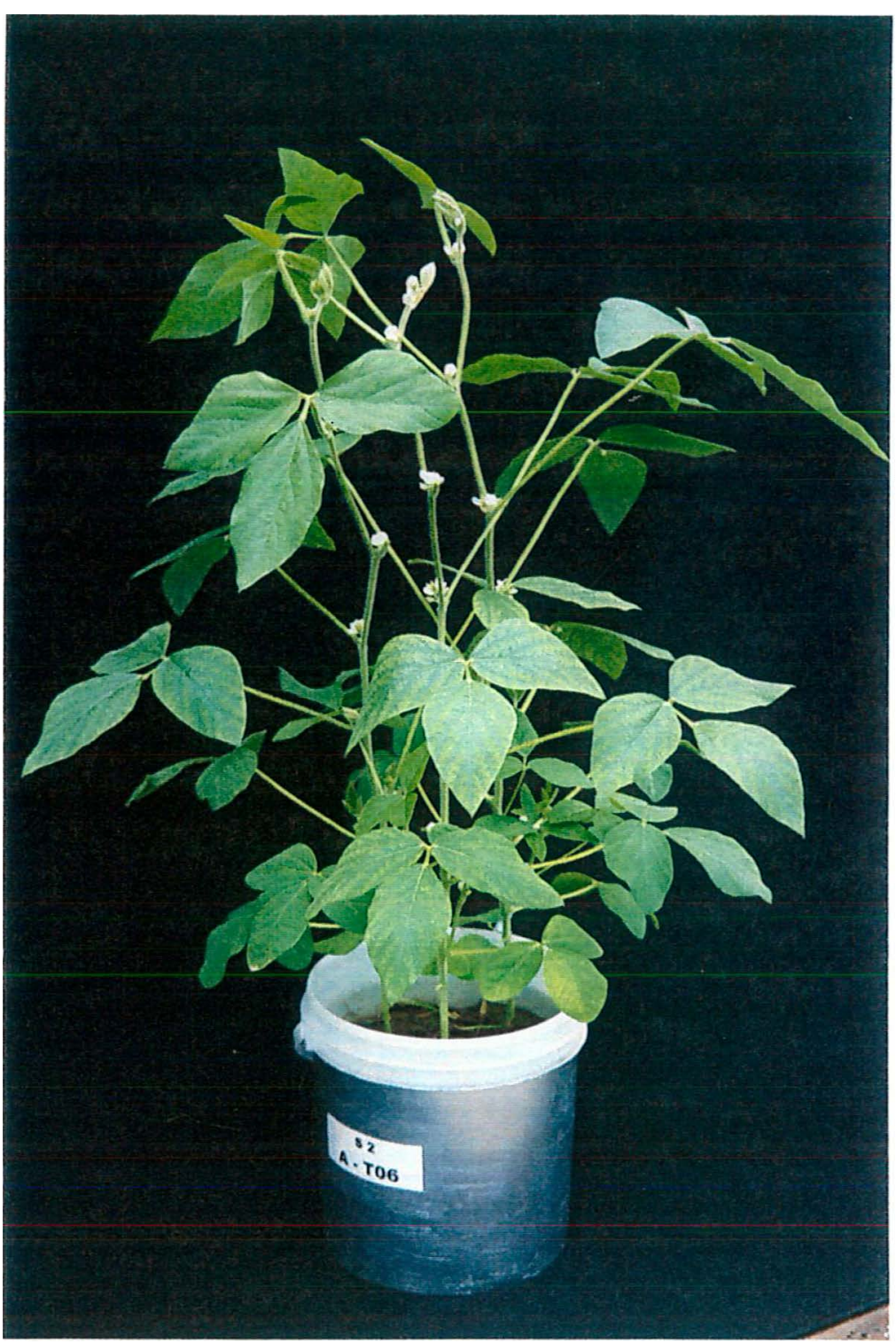

Figura 4. Sintoma visual de deficiência de manganês apresentado no estádio R1, no experimento de casa de vegetação (Época 1).

Os valores obtidos estão também abaixo dos observados por vários autores. Mascarenhas et al. (1980) verificaram teores foliares de manganês 
variando de 20 a $42 \mathrm{mg} \mathrm{kg}^{-1}$. Redferm (1984), trabalhando com doses de fósforo, obteve nível de manganês de $75 \mathrm{mg} \mathrm{kg}^{-1}$ na testemunha (sem adubação com fósforo), a qual não diferiu dos demais tratamentos, enquanto que Ramos et al (1989) obtiveram valores que variaram de 39 a 49, em plantas tratadas com 3,0 Mg ha-1 de calcário. Em outro estudo, desenvolvido por Lazarini (1995), foram encontrados níveis foliares de manganês que variaram de 92 a $116 \mathrm{mg} \mathrm{ha}^{-1}$.

Assim, os resultados obtidos demostraram que tanto o fornecimento de manganês via solo, quanto o fornecimento via semente, não foram suficientes para alterar os níveis foliares do elemento no estádio $\mathrm{R} 1$, revelando a baixa capacidade de suprimento de manganês à planta, pelas fontes e formas de aplicação utilizadas.

Ao contrário do estádio R1, foram observadas diferenças em função dos tratamentos nos níveis foliares de manganês no estádio R4 (Tabela 24).

Os resultados encontrados na testemunha, que não recebeu manganês, mostraram a manutenção do baixo teor foliar do elemento, nessa fase, permanecendo em estado de deficiência.

Por outro lado, o fornecimento de manganês foliar no estádio R1 proporcionou, em R4, níveis foliares mais elevados do elemento que o suprimento via solo e via semente.

Dentre as fontes utilizadas, via foliar, notou-se que os maiores níveis foram encontrados nos tratamentos com $\mathrm{MnSO}_{4} 4 \mathrm{H}_{2} \mathrm{O}$, nas duas doses utilizadas e nas três fontes quelatizadas, os quais não diferiram entre si.

O tratamento com mancozeb, via foliar, resultou em teores pouco abaixo dos demais tratamentos foliares, sendo no entanto superior aos tratamentos testemunha e $\mathrm{MnSO}_{4} 4 \mathrm{H}_{2} \mathrm{O}$ via solo.

Os tratamentos via solo e via semente levaram a teores foliares em R4 menores que os demais tratamentos, não diferindo da testemunha. A dose do elemento de $4000 \mathrm{~g} \mathrm{ha}^{-1}$ talvez não tenha sido suficiente, concordando com o obtido por Randall et al. (1975). 
Assim, pode-se inferir que para o parâmetro nível foliar de manganês, o fornecimento do elemento via foliar mostrou-se com maior eficiência, uma vez que a dose aplicada foi até 20 vezes menor do que a utilizada via solo, estando de acordo com o observado por Volkweiss (1991).

A comparação de médias dos níveis foliares de micronutrientes entre os estádios R1 e R4 (Tabela 25) revelou que os teores foliares de cobre e zinco não sofreram alteração, enquanto que foi verificado aumento nos teores de boro, ferro e, evidentemente, de manganês.

Tabela 25. Comparação entre médias dos teores foliares de micronutrientes, nos estádios R1 e R4, do experimento de casa de vegetação (Época 1).

\begin{tabular}{|c|c|c|c|c|c|}
\hline Estádio & $\bar{B}$ & $\mathrm{Cu}$ & $\overline{\mathrm{Fe}}$ & $\overline{M n}$ & $\overline{Z n}$ \\
\hline & .......... & $\ldots \ldots$ & $\mathrm{mg} \mathrm{kg}^{-1}$ & $\ldots \ldots$ & $\ldots \ldots$. \\
\hline R1 & $41,6 b^{1}$ & 4,9 & $85,8 b$ & $16,9 b$ & 38,0 \\
\hline R4 & $55,2 a$ & 4,8 & $95,2 a$ & $37,0 a$ & 37,5 \\
\hline $\begin{array}{c}\text { Valor de F } \\
\text { C.V. (\%) }\end{array}$ & $\begin{array}{l}42,46^{\star \star} \\
19,17\end{array}$ & $\begin{array}{l}0,15^{\mathrm{ns}} \\
34,53\end{array}$ & $\begin{array}{c}4,53^{*} \\
21,82\end{array}$ & $\begin{array}{c}109,15^{\star \star} \\
31,84\end{array}$ & $\begin{array}{c}0,16^{\mathrm{ns}} \\
13,82\end{array}$ \\
\hline
\end{tabular}

Letras minúsculas: comparação em cada coluna, pelo teste de Tukey a $5 \%$ de probabilidade.

*TesteF significativo a 5\%; ** Teste $F$ significativo a $1 \%$

O elemento $\mathrm{B}$, a exemplo do $\mathrm{Ca}$, é praticamente imóvel na planta quanto a sua redistribuição, o que pode explicar um certo acúmulo deste elemento nas folhas, mesmo num período de grande demanda como é o estádio R4. Além disso, não houve restrição ao seu fornecimento via solo, permitindo adequado suprimento do nutriente e justificando o aumento do nível foliar de boro, verificado nesta fase.

De modo semelhante, a baixa mobilidade do $\mathrm{Fe}$ aliada ao fornecimento adequado deste nutriente pelo solo poderá ter contribuído pelo pequeno aumento observado entre os níveis foliares de R1 para R4. 
Poucos trabalhos apresentaram resultados para os teores foliares desses micronutrientes, em estádios posteriores ao período de florescimento da soja. Malavolta et al. (1980) encontraram teores de B, Cu, e Zn de 59 e 38, 6 e 6; 30 e $34 \mathrm{mg} \mathrm{kg}^{-1}$, respectivamente, para as variedades Santa Rosa e UFV-1 no período de formação de vagens, ou seja, semelhantes aos resultados obtidos pelo presente trabalho.

\subsubsection{Teor de clorofila nas folhas}

Os resultados verificados pelas leituras realizadas nos estádios $\mathrm{R} 1 \mathrm{e}$ R4, pelo aparelho clorofilômetro (SPAD), encontram-se na Tabela 26.

Em relação à leitura do teor de pigmento, observou-se que não houve diferença entre os tratamentos em cada época amostrada. No entanto, verificaram-se diferenças em alguns tratamentos entre as leituras realizadas em $\mathrm{R} 1$, em comparação ao estádio R4, levando-se ao aumento na leitura média do estádio R1 para o R4.

Neste sentido, os tratamentos $\mathrm{MnSO}_{4} 4 \mathrm{H}_{2} \mathrm{O}$ foliar (350 $\mathrm{g} \mathrm{ha}{ }^{-1}$ ), Quelado $\mathrm{Cl}^{-}$foliar (200 $\mathrm{g} \mathrm{ha}^{-1}$ ), Quelado $\mathrm{NO}^{3}$ foliar (200 $\mathrm{g} \mathrm{ha}^{-1}$ ) e Quelado $\mathrm{SO}_{4}$ semente $\left(300 \mathrm{~g} \mathrm{ha}^{-1}\right)$ apresentaram aumento de coloração verde em relação à amostragem anterior, revelado pela leitura, fato este que pode indicar possivel detecção da redução na clorose conferida pelo fornecimento de manganês nestes tratamentos. Contudo, comparando-se os resultados de leitura do teor de pigmento com os teores foliares de manganês, encontrados no estádio R4 (Tabela 24), não se pode ainda estabelecer uma correlação adequada entre um e outro. 
Tabela 26. Avaliação do teor de pigmento nas folhas, obtido pelo aparelho clorofilômetro, no experimento de casa de vegetação (Época 1).

\begin{tabular}{|c|c|c|c|}
\hline \multirow[t]{2}{*}{ Tratamentos } & \multicolumn{3}{|c|}{ Leitura do teor de pigmento } \\
\hline & R1 & R4 & MÉDIA \\
\hline & \multicolumn{3}{|c|}{ SPAD. } \\
\hline Testemunha & $38,5 a A^{1}$ & $37,9 a A$ & $38,2 a$ \\
\hline $\mathrm{MnSO}_{4} 4 \mathrm{H}_{2} \mathrm{O}\left(350 \mathrm{~g} \mathrm{ha}^{-1}\right)$ - foliar & $38,3 a B$ & $42,5 \mathrm{aA}$ & $40,4 a$ \\
\hline $\mathrm{MnSO}_{4} 4 \mathrm{H}_{2} \mathrm{O}\left(200 \mathrm{~g} \mathrm{ha}^{-1}\right)$ - foliar & $38,0 a A$ & $41,5 \mathrm{aA}$ & $39,7 a$ \\
\hline Quelado $\mathrm{Cl}^{-}\left(200 \mathrm{~g} \mathrm{ha}^{-1}\right)$ - foliar & $37,4 a B$ & $41,7 \mathrm{aA}$ & $39,5 a$ \\
\hline Quelado $\mathrm{NO}_{3}^{-}\left(200 \mathrm{~g} \mathrm{ha}^{-1}\right)$ - foliar & $34,9 a \mathrm{a}$ & $41,3 a A$ & $38,1 a$ \\
\hline Quelado $\mathrm{SO}_{4}^{-2}\left(200 \mathrm{~g} \mathrm{ha}^{-1}\right)$ - foliar & $38,8 a A$ & $40,8 \mathrm{aA}$ & $39,8 a$ \\
\hline Mancozeb (200 g ha $\left.{ }^{-1}\right)$ - foliar & $39,3 a A$ & $39,7 a A$ & $39,5 a$ \\
\hline $\mathrm{MnSO}_{4} 4 \mathrm{H}_{2} \mathrm{O}\left(4000 \mathrm{~g} \mathrm{ha}^{-1}\right)$ - solo & $37,3 a A$ & $39,7 a A$ & $38,5 a$ \\
\hline Oxi-sulfato Mn (4000g ha-1) - solo & $36,1 \mathrm{aA}$ & $39,0 a A$ & $38,1 a$ \\
\hline Quelado $\mathrm{SO}_{4}^{-2}\left(300 \mathrm{~g} \mathrm{ha}^{-1}\right)$ - sem. & $36,4 a B$ & $40,4 a A$ & $38,4 a$ \\
\hline MEDIA & $37,5 \mathrm{~B}$ & $40,4 \mathrm{~A}$ & \\
\hline $\begin{array}{l}\text { Valor de F } \\
\text { C.V. }(\%)\end{array}$ & $\begin{array}{c}25,79^{\star \star} \\
6,65\end{array}$ & & \\
\hline
\end{tabular}

A partir dessas leituras, aplicou-se a equação proposta por Barnes et al. (1992), obtendo-se os teores de clorofila em $\mathrm{mg} \mathrm{dm}^{-2}$ (Tabela 27). Os resultados obtidos foram semelhantes aos encontrados na leitura de pigmento, não sendo verificadas diferenças em função dos tratamentos.

Esta ausência de resposta entre os tratamentos à coloração ou teor de clorofila, mesmo após o fornecimento de manganês foliar, pode indicar que o tempo decorrido entre a aplicação do elemento (estádio R1) e a leitura realizada (estádio R4) seja suficiente para elevar os teores foliares de manganês, como 
comentado anteriormente, porém insuficiente para reverter total ou parcialmente o sintoma de clorose estabelecido.

Tabela 27. Concentração de clorofila nas folhas, no experimento de casa de vegetação (Época 1).

\begin{tabular}{|c|c|c|c|}
\hline \multirow[t]{2}{*}{ Tratamentos } & \multicolumn{3}{|c|}{ Teor de clorofila } \\
\hline & R1 & R4 & MÉDIA \\
\hline & \multicolumn{3}{|c|}{$\ldots \mathrm{mg} \mathrm{dm^{-2 }}$} \\
\hline Testemunha & $3,68 a A^{1}$ & $3,62 \mathrm{aA}$ & $3,65 a$ \\
\hline $\mathrm{MnSO}_{4} 4 \mathrm{H}_{2} \mathrm{O}\left(350 \mathrm{~g} \mathrm{ha}^{-1}\right)$ - foliar & $3,66 \mathrm{aB}$ & $4,08 \mathrm{aA}$ & $3,87 a$ \\
\hline $\mathrm{MnSO}_{4} 4 \mathrm{H}_{2} \mathrm{O}\left(200 \mathrm{~g} \mathrm{ha}^{-1}\right)$ - foliar & $3,63 a A$ & $3,97 \mathrm{aA}$ & $3,80 a$ \\
\hline Quelado $\mathrm{Cl}^{-}\left(200 \mathrm{~g} \mathrm{ha}^{-1}\right)$ - foliar & $3,57 a B$ & $3,99 \mathrm{aA}$ & $3,78 a$ \\
\hline Quelado $\mathrm{NO}_{3}^{-}\left(200 \mathrm{~g} \mathrm{ha}^{-1}\right)$ - foliar & $3,32 \mathrm{aB}$ & $3,96 \mathrm{aA}$ & $3,64 a$ \\
\hline Quelado $\mathrm{SO}_{4}^{-2}\left(200 \mathrm{~g} \mathrm{ha}^{-1}\right)$ - foliar & $3,71 \mathrm{aA}$ & $3,91 \mathrm{aA}$ & $3,81 a$ \\
\hline Mancozeb (200 g ha $\left.{ }^{-1}\right)$ - foliar & $3,76 a A$ & $3,80 a A$ & $3,78 a$ \\
\hline $\mathrm{MnSO}_{4} 4 \mathrm{H}_{2} \mathrm{O}\left(4000 \mathrm{~g} \mathrm{ha}^{-1}\right)$ - solo & $3,56 a A$ & $3,80 a A$ & $3,68 a$ \\
\hline Oxi-sulfato Mn (4000g ha-1) - solo & $3,69 a A$ & $3,73 a A$ & $3,71 \mathrm{a}$ \\
\hline Quelado $\mathrm{SO}_{4}^{-2}\left(300 \mathrm{~g} \mathrm{ha}^{-1}\right)$ - sem. & $3,47 \mathrm{aB}$ & $3,87 a A$ & $3,67 a$ \\
\hline MÉDIA & $3,60 \mathrm{~B}$ & $3,87 \mathrm{~A}$ & \\
\hline $\begin{array}{l}\text { Valor de F } \\
\text { C.V. }(\%) \\
\end{array}$ & $\begin{array}{c}23,30^{\star \star} \\
6,67 \\
\end{array}$ & & \\
\hline
\end{tabular}

\subsubsection{Produção de grãos}

O número e o percentual de vagens com $0,1,2$ e 3 grãos e grãos chochos encontrados estão apresentados na Tabela 28. 


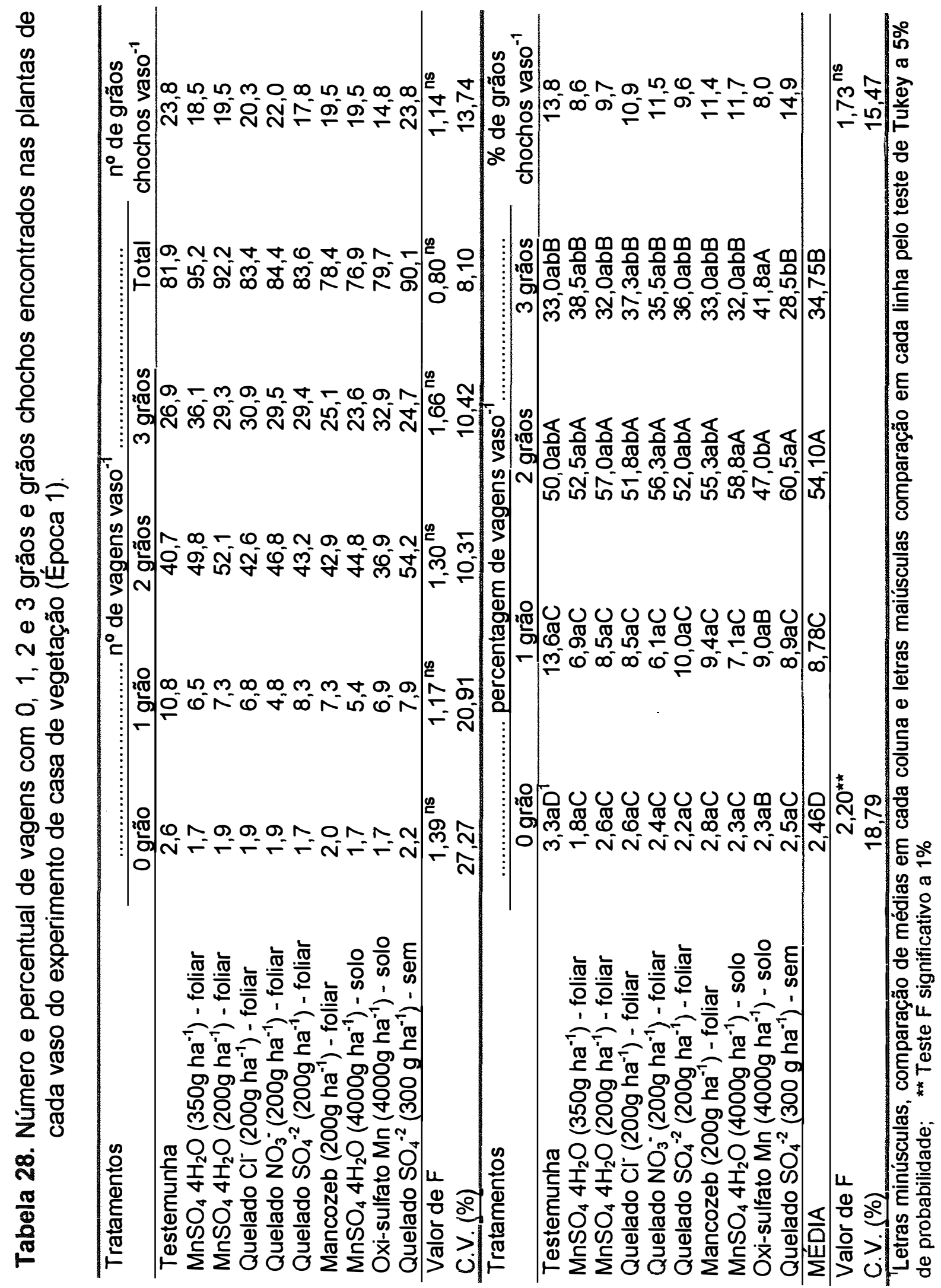


Os resultados revelaram que não houve diferença entre os tratamentos para o número de vagens produzidas e o número de grãos chochos obtidos. Observou-se, no entanto, que as plantas que receberam tratamento com oxi-sulfato de $\mathrm{Mn}$ ( $4000 \mathrm{~g} \mathrm{ha}^{-1}$, via solo) apresentaram maior percentual de vagens com 3 grãos em comparação a vagens com 2 grãos. Comportamento inverso foi verificado nas plantas tratadas com quelado $\mathrm{SO}_{4}^{-2}\left(300 \mathrm{~g} \mathrm{ha}^{-1}\right.$, via semente) que mostraram maior percentagem de vagens com 2 grãos e menor de vagens com 3 grãos. Por outro lado, esta diferença percentual não foi capaz de alterar em números absolutos a produção de vagens, conforme já comentado.

Em relação à produção de grãos (Tabela 29) não foram encontradas diferenças entre os tratamentos.

Tabela 29. Dados de produção de grãos do experimento de casa de vegetação (Época 1)

\begin{tabular}{|c|c|c|}
\hline \multirow[t]{2}{*}{ Tratamentos } & \multicolumn{2}{|c|}{ Produção de grãos } \\
\hline & $\mathrm{n}^{0}$ de grãos vaso ${ }^{-7}$ & $\ldots \mathrm{g} \mathrm{vaso}^{-1} \ldots$ \\
\hline Testemunha & 174 & 22,186 \\
\hline $\mathrm{MnSO}_{4} 4 \mathrm{H}_{2} \mathrm{O}\left(350 \mathrm{~g} \mathrm{ha}^{-1}\right)$ - foliar & 216 & 27,437 \\
\hline $\mathrm{MnSO}_{4} 4 \mathrm{H}_{2} \mathrm{O}\left(200 \mathrm{~g} \mathrm{ha}^{-1}\right)$ - foliar & 201 & 25,946 \\
\hline Quelado $\mathrm{Cl}^{-}\left(200 \mathrm{~g} \mathrm{ha}^{-1}\right)$ - foliar & 187 & 25,008 \\
\hline Quelado $\mathrm{NO}_{3}^{-}\left(200 \mathrm{~g} \mathrm{ha}^{-1}\right)$ - foliar & 189 & 24,962 \\
\hline Quelado $\mathrm{SO}_{4}^{-2}\left(200 \mathrm{~g} \mathrm{ha}^{-1}\right)$ - foliar & 185 & 25,726 \\
\hline Mancozeb (200 g ha-1 $)$ - foliar & 170 & 24,074 \\
\hline $\mathrm{MnSO}_{4} 4 \mathrm{H}_{2} \mathrm{O}\left(4000 \mathrm{~g} \mathrm{ha}^{-1}\right)$ - solo & 168 & 22,520 \\
\hline Oxi-sulfato Mn (4000g ha-1) - solo & 183 & 24,207 \\
\hline Quelado $\mathrm{SO}_{4}^{-2}\left(300 \mathrm{~g} \mathrm{ha}^{-1}\right)$ - semente & 168 & 21,924 \\
\hline $\begin{array}{l}\text { Valor de F } \\
\text { C.V. }(\%)\end{array}$ & $\begin{array}{c}1,18^{\text {ns }} \\
15,51\end{array}$ & $\begin{array}{c}1,42^{\text {ns }} \\
12,30\end{array}$ \\
\hline
\end{tabular}


Esses resultados indicaram que a aplicação de manganês, no estádio R1, pelos tratamentos foliares, não foi suficiente para promover alteração no número e massa de grãos produzidos, mesmo tendo possibilitado a elevação dos teores foliares de manganês. Foi observado, também, que o fornecimento do manganês via solo e via semente não foi eficiente em relação ao aumento de produção de grãos.

Do mesmo modo, não foram encontradas diferenças em função dos tratamentos para a massa de 100 grãos (Tabela 30).

Tabela 30. Dados de massa de 100 grãos do experimento de casa de vegetação (Época 1)

Tratamentos

Massa de 100 grãos

g

Testemunha

12,817

$\mathrm{MnSO}_{4} 4 \mathrm{H}_{2} \mathrm{O}\left(350 \mathrm{~g} \mathrm{ha}^{-1}\right)$ - foliar

12,742

$\mathrm{MnSO}_{4} 4 \mathrm{H}_{2} \mathrm{O}\left(200 \mathrm{~g} \mathrm{ha}^{-1}\right)$ - foliar

12,888

Quelado $\mathrm{Cl}^{-}\left(200 \mathrm{~g} \mathrm{ha}^{-1}\right)$ - foliar

13,665

Quelado $\mathrm{NO}_{3}^{-}\left(200 \mathrm{~g} \mathrm{ha}^{-1}\right)$ - foliar

13,250

Quelado $\mathrm{SO}_{4}^{-2}$ (200 $\mathrm{g} \mathrm{ha}^{-1}$ ) - foliar

13,933

Mancozeb (200 $\mathrm{g} \mathrm{ha}^{-1}$ ) - foliar

14,257

$\mathrm{MnSO}_{4} 4 \mathrm{H}_{2} \mathrm{O}$ (4000 $\mathrm{g} \mathrm{ha}^{-1}$ ) - solo

13,576

Oxi-sulfato $\mathrm{Mn}\left(4000 \mathrm{~g} \mathrm{ha}^{-1}\right)$ - solo

13,343

Quelado $\mathrm{SO}_{4}^{-2}\left(300 \mathrm{~g} \mathrm{ha}^{-1}\right)$ - semente

13,276

Valor de F

$0,57^{\text {ns }}$

C.V. (\%)

9,72 


\subsubsection{Produção de matéria seca}

A produção de matéria seca total e das diferentes partes da planta não diferiram entre si em consequência dos tratamentos (Tabela 31). $O$ índice de colheita (IC) também não foi alterado pelo fornecimento de manganês. Estes resultados ratificam que tanto a aplicação de $\mathrm{Mn}$ no plantio (via solo ou semente) quanto a aplicação foliar em R1 não foram suficientes para influenciar a produção de matéria seca total e de nenhuma parte isolada da planta, assim como da relação entre o produto colhido e a matéria seca total (IC).

\subsubsection{Teores de nutrientes nos grãos}

Os teores de macro e micronutrientes encontrados nos grãos estão apresentados nas Tabelas 32 e 33, respectivamente. Os resultados revelaram que não houve diferença entre os tratamentos para nenhum dos elementos analisados.

$\mathrm{Na}$ literatura, diversos trabalhos com diferentes cultivares de soja revelaram teores de nutrientes nos grãos variando entre: 50,4 a 65,7 g kg-1 para $\mathrm{N} ; 3,7$ a 5,9 $\mathrm{g} \mathrm{kg}^{-1}$ para $\mathrm{P} ; 11,7$ a $21,0 \mathrm{~g} \mathrm{~kg}^{-1}$ para $\mathrm{K} ; 2,3$ a $6,5 \mathrm{~g} \mathrm{~kg}^{-1}$ para Ca; 2,0 a 3,2 $\mathrm{g} \mathrm{kg}^{-1}$ para Mg; 1,5 a 5,4 $\mathrm{g} \mathrm{kg}^{-1}$ para $\mathrm{S} ; 20 \mathrm{mg} \mathrm{kg}^{-1}$ para B; 9,3 a $41 \mathrm{mg} \mathrm{kg}^{-1}$ para Cu; 70 a $150 \mathrm{mg} \mathrm{kg}^{-1}$ para Fe; 21 a $38 \mathrm{mg} \mathrm{kg}^{-1}$ para Mn e 40 a $96 \mathrm{mg} \mathrm{kg}^{-1}$ para Zn (Mascarenhas et al., 1980; Oliveira et al., 1991; Lazarini, 1995; Embrapa, 1998). 


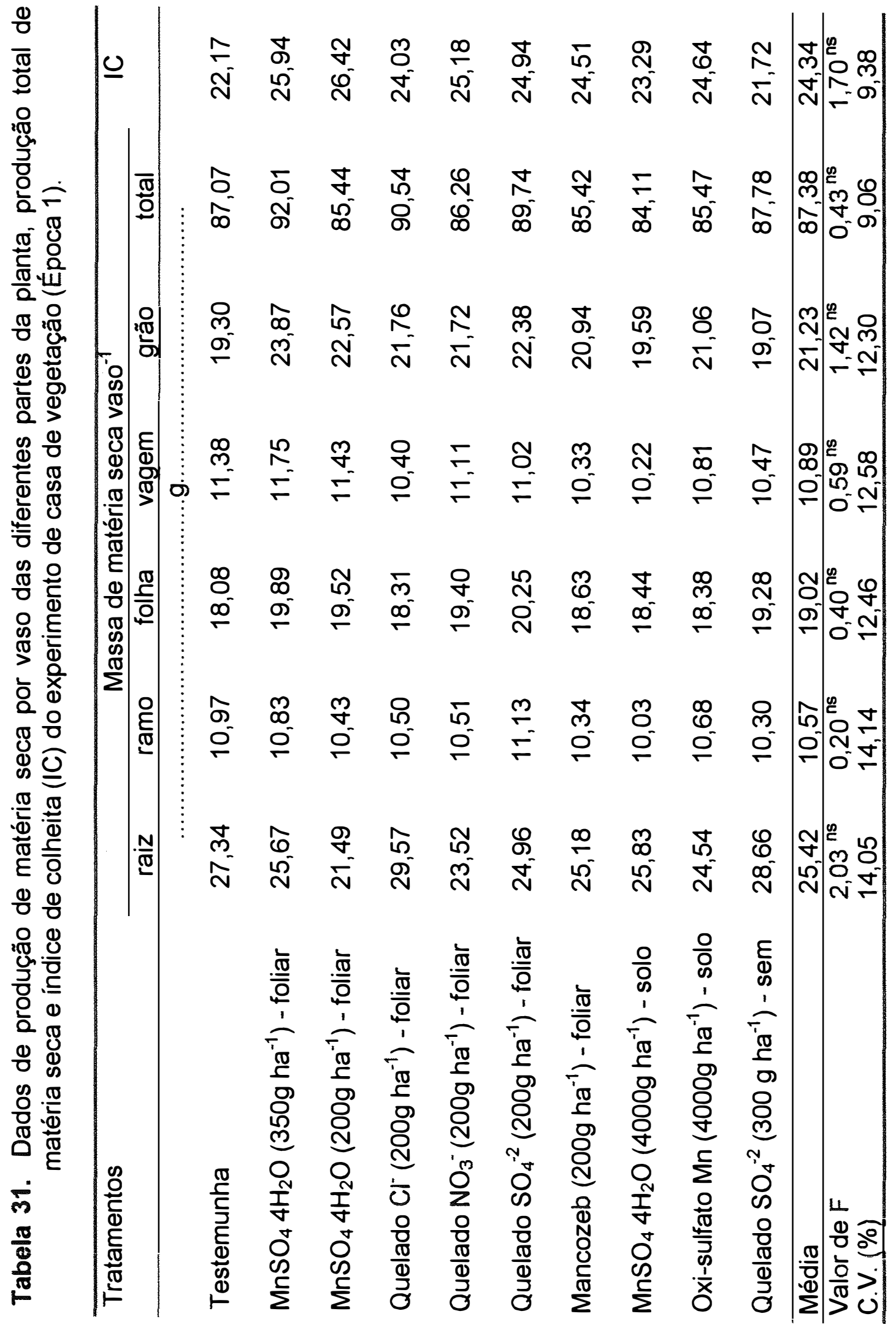




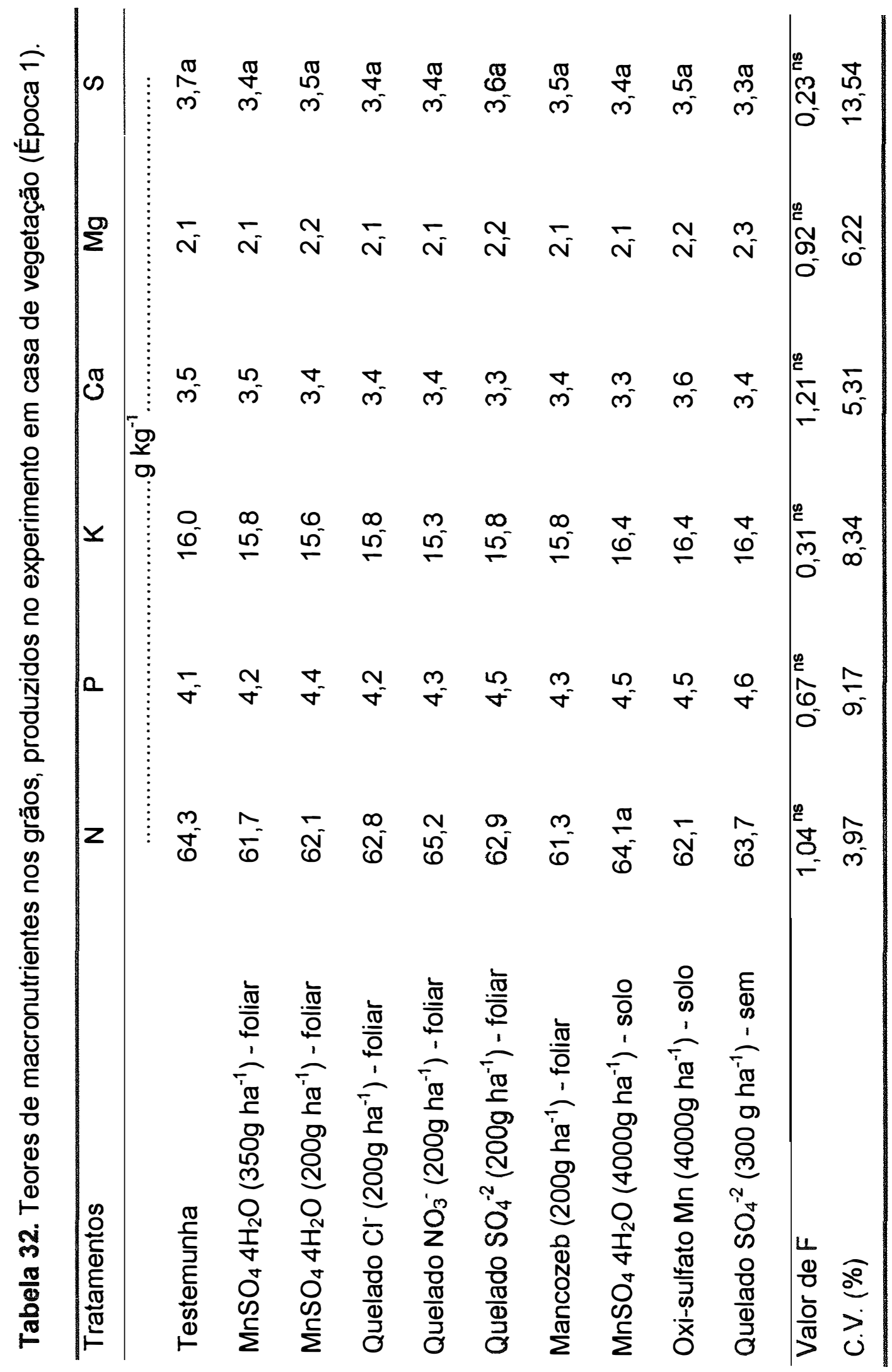




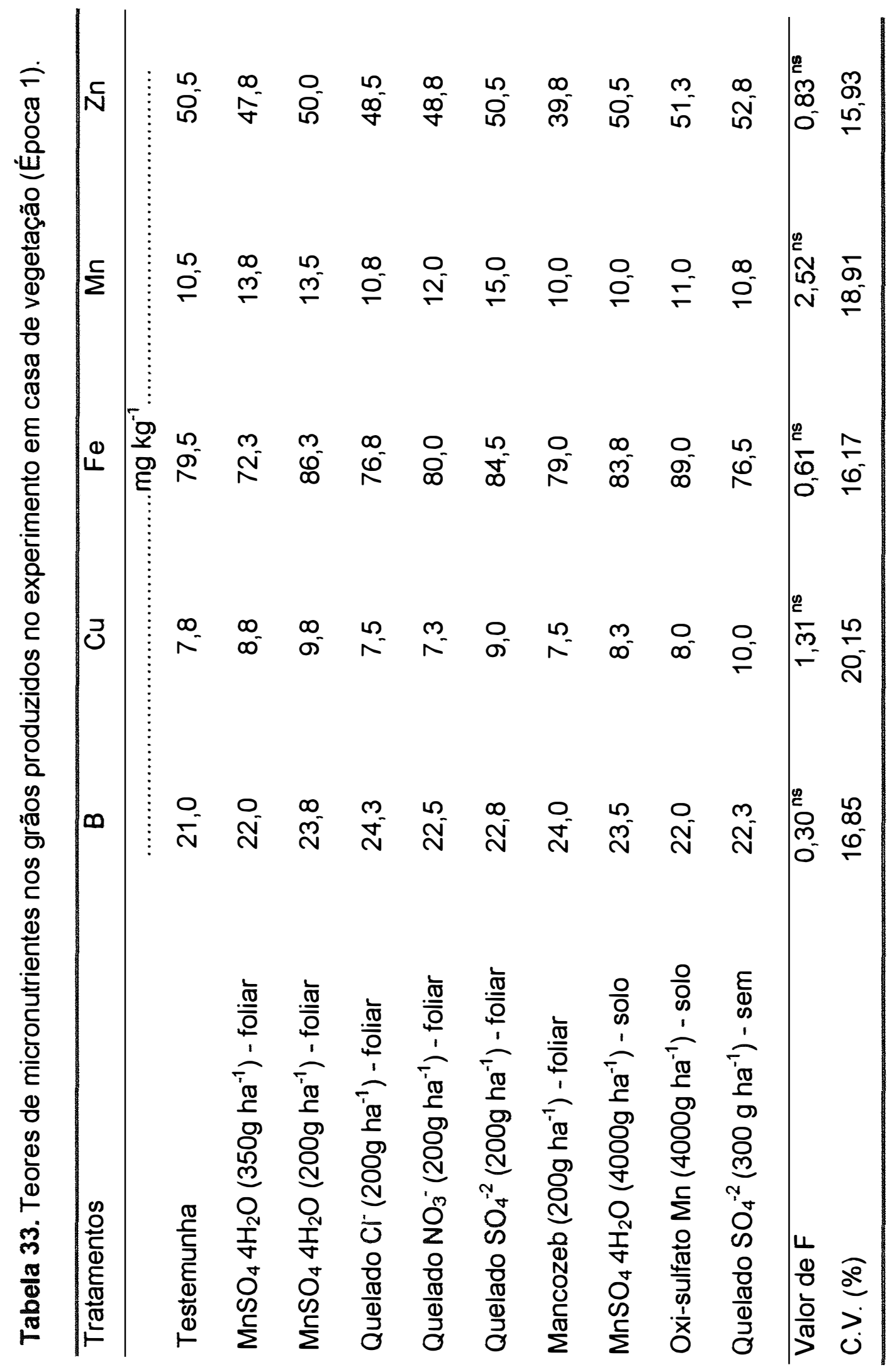


Observou-se, portanto, que de maneira geral, com exceção do elemento manganês os valores obtidos foram semelhantes aos encontrados em outros trabalhos. Este fato pode indicar que as condições de deficiência de manganês estabelecidas, conforme observado pelos resultados dos teores foliares do elemento em R1, influenciaram o baixo acúmulo de $\mathrm{Mn}$ nos grãos, não sendo possivel alterar os niveis do elemento pelo fornecimento via solo e, muito menos, pela aplicação foliar, no estádio R1. Provavelmente, esta venha a ser uma das ocorrências que melhor se relacionaram à ausência de resposta dos tratamentos sobre a produção de grãos.

\subsubsection{Análises químicas de solo}

Os resultados referentes às análises químicas de solo estão apresentados na Tabela 34. Pode-se observar que, com exceção do manganês, não foram verificadas diferenças entre os tratamentos estudados.

De acordo com os resultados obtidos, os valores encontrados para os macronutrientes $\mathrm{P}, \mathrm{Ca}, \mathrm{Mg}$ e $\mathrm{S}$ estavam em niveis considerados altos (Raij et al., 1996), sendo que o $P$ e o $S$ alcançaram teores maiores aos verificados no solo original (Tabela 2), em razão do fornecimento de fósforo, via superfosfato simples, na adubação básica dos vasos (Tabela 4). 


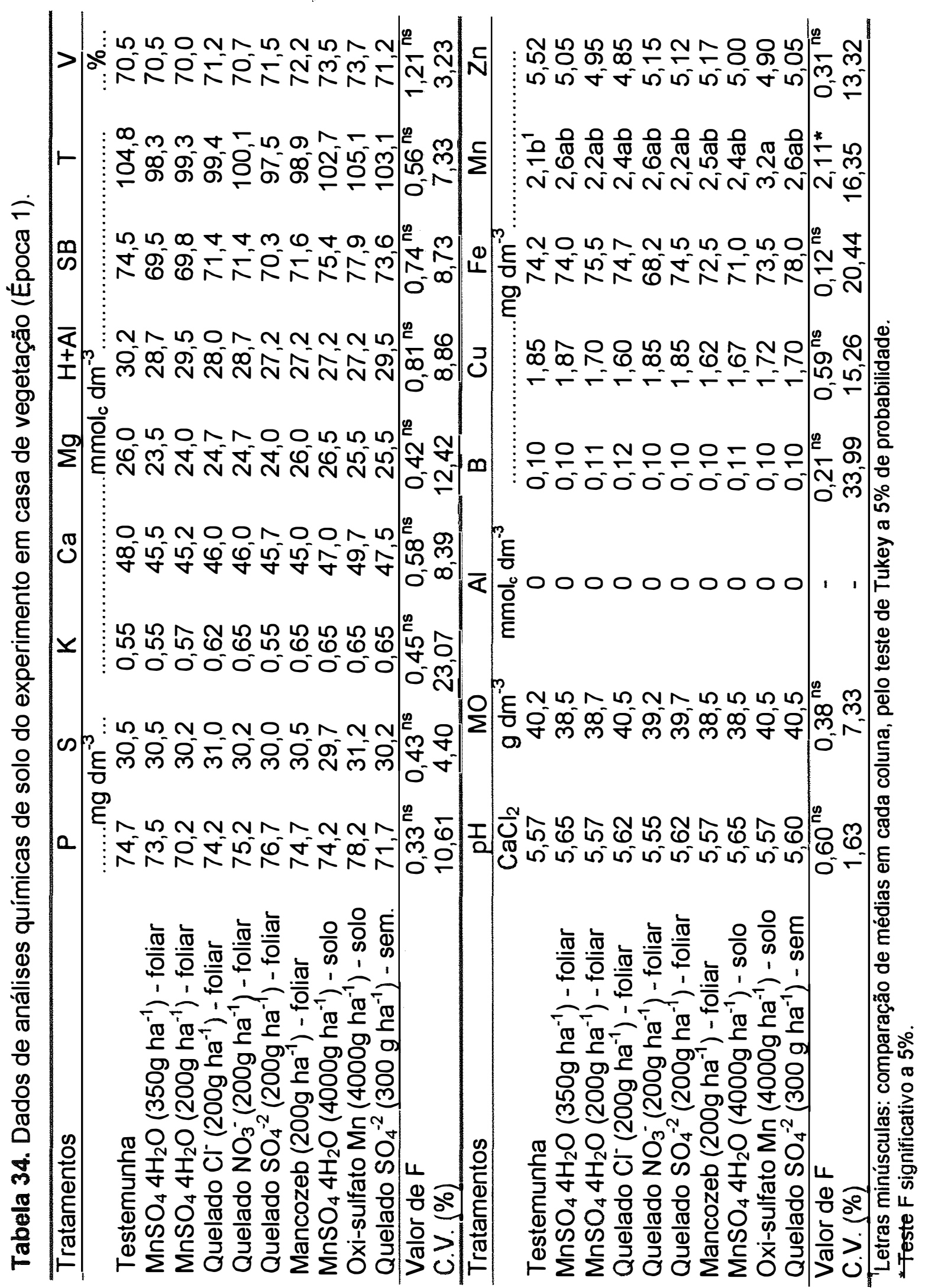


A suscetibilidade à lixiviação do $K$, favorecendo seu acúmulo na camada de terra próxima ao fundo do vaso e dificultando uma amostragem adequada para este nutriente assim como a alta extração de potássio verificada pela planta de soja (Bataglia \& Mascarenhas, 1977), podem explicar os baixos teores deste elemento, encontrados pela análise de solo, os quais foram menores que o obtido na análise inicial (Tabela 2).

Os dados de saturação por bases (V\%) mantiveram-se nos mesmos níveis encontrados na análise inicial (Tabela 2), sendo considerados elevados, uma vez que para as condições de solos sob cerrado, na Região Central do Brasil, valores adequados seriam ao redor de 50\% (Sousa et al., 1989 e Embrapa, 1998). Raij et al. (1997) consideraram como altos, independente da cultura e tipo de solo, valores superiores a $70 \%$ e especificamente para soja consideraram como adequado o valor de $60 \%$.

Esses resultados retrataram bem a realidade existente no campo, pois a ausência de incorporação de calcário e a retirada de solo da superfície do terreno $(0-10 \mathrm{~cm})$, para utilização nos vasos, proporcionaram valores elevados de saturação por bases.

Quanto aos valores obtidos de $\mathrm{pH}\left(\mathrm{CaCl}_{2}\right)$, observou-se que não houve alteração em relação à análise inicial, sendo considerados de baixa acidez (Raij et al., 1997), o que pode ser explicada pelos mesmos motivos relatados para a saturação por bases.

A exemplo da amostra inicial, não foi verificada presença de alumínio trocável no solo.

Em relação ao teor de matéria orgânica, os valores encontrados foram coerentes ao esperado num solo de textura argilosa (entre 31 a $60 \mathrm{~g} \mathrm{dm}^{-3}$, segundo Raij et al., 1997). No entanto, verificou-se um ligeiro aumento em relação aos valores iniciais (Tabela 2), o que pode ser explicado pela significativa presença do sistema radicular das plantas de soja nas amostras de solo, na época da coleta. 
Os teores de micronutrientes, à exceção do manganês, não variaram em função dos tratamentos. Para o extrator utilizado (DTPA) os valores de $\mathrm{Cu}$, Fe e $\mathrm{Zn}$ encontraram-se em niveis considerados altos (Raij et al., 1997) sendo inclusive superiores aos observados inicialmente (Tabela 3), manifestando o efeito da aplicação realizada na implantação do experimento (Tabela 4).

No caso do $B$, os resultados revelaram níveis que, além de considerados baixos, foram menores aos teores médios encontrados na análise inicial. O B na faixa de $\mathrm{pH}$ de 5,5 a 6,5 é um elemento passivel de lixiviação (Dantas, 1991), podendo sofrer o mesmo processo de acúmulo no fundo do vaso explicado anteriormente para o K. Esta ocorrência pode justificar os baixos niveis encontrados no solo, mesmo com a aplicação inicial deste elemento no solo antes da semeadura (Tabela 4).

Os resultados dos niveis de $\mathrm{Mn}$ no solo revelaram que apenas a aplicação deste elemento via solo, na forma de oxi-sulfato de manganês (4000 $\mathrm{g} \mathrm{ha}^{-1}$ ), promoveu aumento em relação à testemunha. No entanto, todos os valores encontraram-se em niveis considerados médios para 0 extrator utilizado, DTPA, segundo os critérios de Raij et al. (1997) e praticamente iguais aos encontrados na amostra inicial.

Esses resultados revelaram que, mesmo com a presença de teores de Mn no solo considerados médios, não foi possivel suprir satisfatoriamente as exigências das plantas, conforme observou-se nos teores foliares do estádio R1 (Tabela 20).

Evidenciou-se portanto, que a presença do elemento no solo não implicou necessariamente na sua disponibilidade para a planta. A baixa acidez encontrada e os altos teores de $\mathrm{Ca}$ e $\mathrm{Mg}$, refletindo na elevada saturação de bases do solo, contribuiram para a indução da deficiência de $\mathrm{Mn}$, conforme observaram também Tanaka et al. (1992). Nesse sentido os elevados teores de Ca e Mg encontrados no solo podem ter inibido a absorção e transporte do manganês, confirmando os relatos de Malavolta et al. (1997). Os próprios 
teores elevados de $\mathrm{P}$, presentes no solo, favoreceram a redução da disponibilidade do manganês à planta (Malavolta et al., 1991).

Do mesmo modo, os elevados teores de $\mathrm{Cu}, \mathrm{Fe}$ e $\mathrm{Zn}$ encontrados no solo também podem ter contribuído para induzir a deficiência do manganês, estando de acordo com as observações feitas por Marinho (1988).

Assim, a análise dos atributos químicos encontrados no solo permitiu concluir que várias razões levaram a comprometer a disponibilidade do manganês à planta, justificando a ocorrência de deficiência no experimento mesmo nas plantas que receberam o elemento via solo. Por outro lado, o fornecimento do elemento via foliar impediu que o $\mathrm{Mn}$ ficasse sujeito às reações de perdas, nessas condições de solo, aumentando seu índice de utilização pela planta e permitindo a elevação dos níveis foliares do elemento (Tabela 24), conforme já comentado. Estes resultados concordaram com as observações feitas por Volkweiss (1991).

\subsection{Experimento em casa de vegetação (Época 2)}

\subsubsection{Teores foliares de nutrientes}

Os teores foliares de macronutrientes nos estádios fenológicos V4, R1 e R4 estão apresentados nas Tabelas 35, 36 e 37, respectivamente.

Nas três épocas de amostragem estudadas, não foram encontradas diferenças entre os níveis foliares de macronutrientes, em função dos tratamentos. 


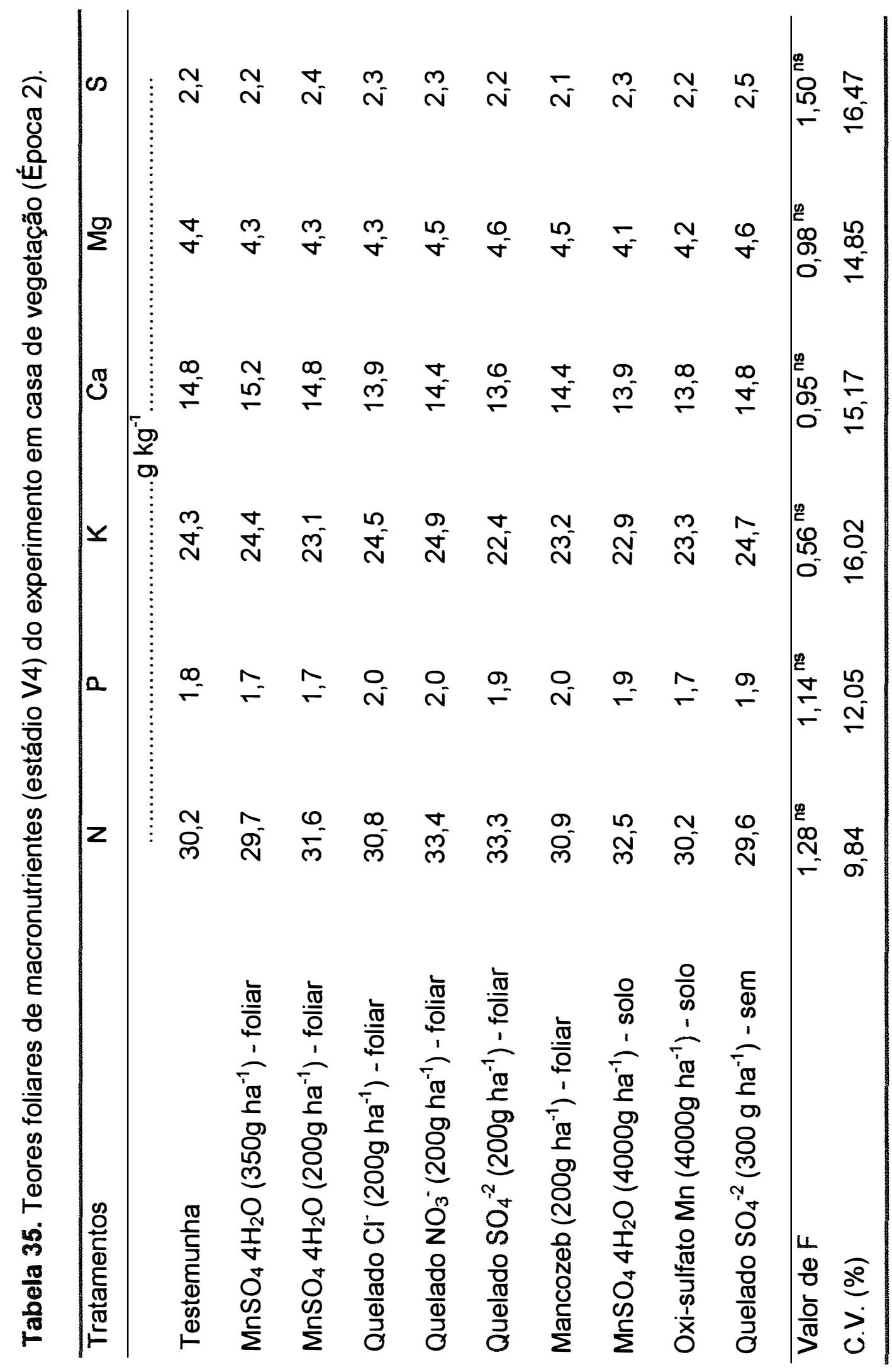




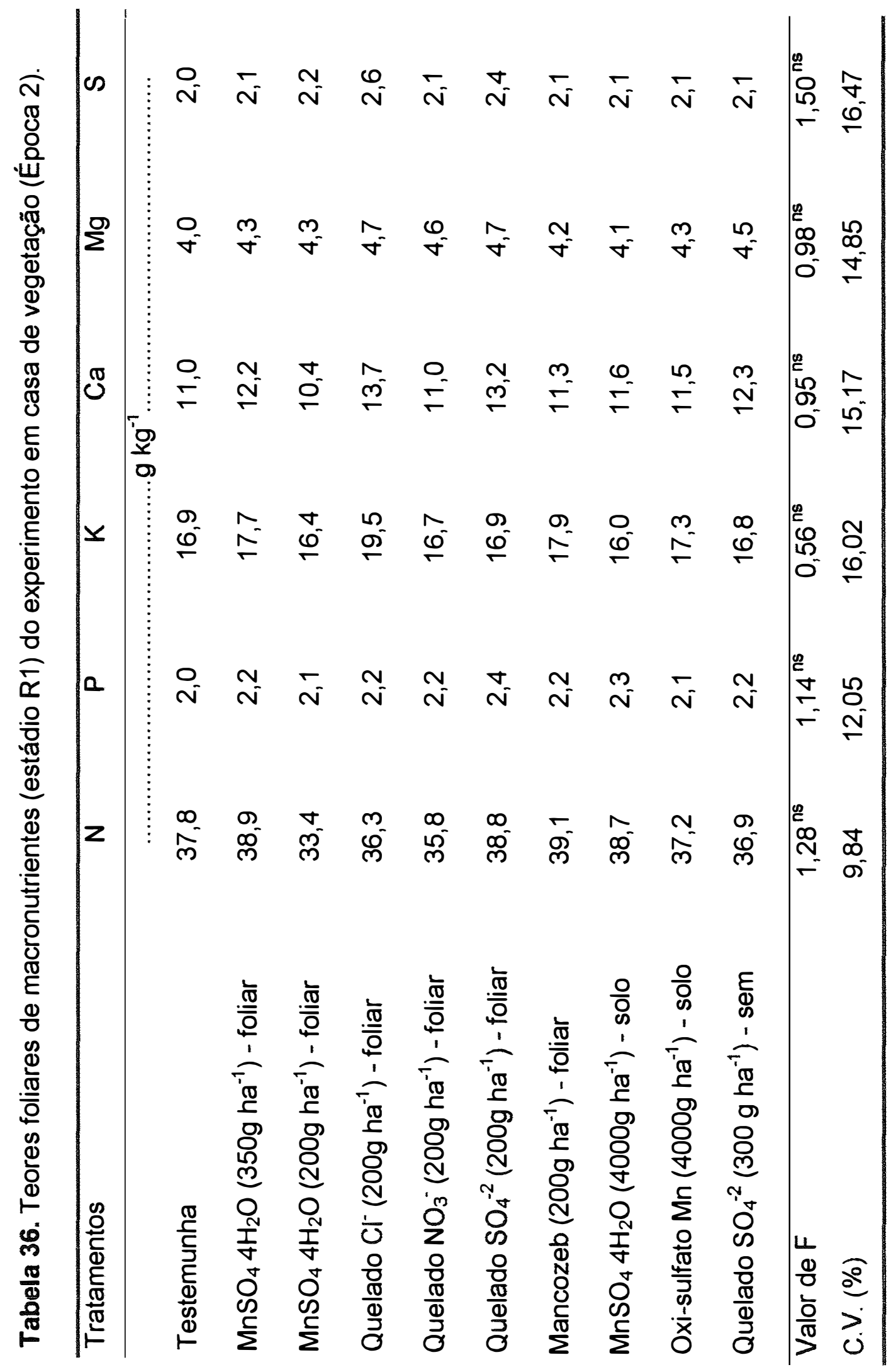




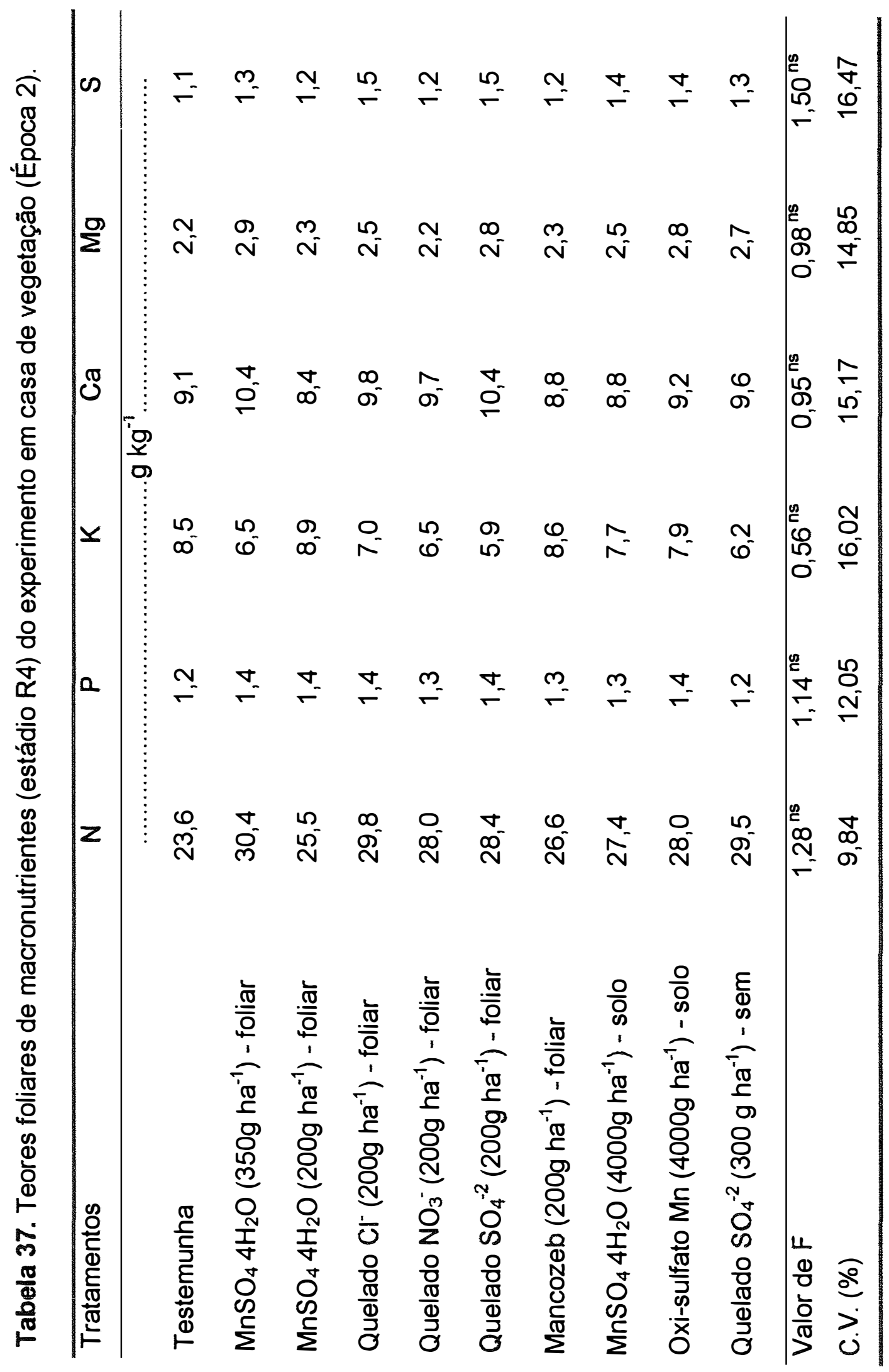


Os niveis de $\mathrm{N}$ e P no estádio R1 (Tabela 36) apresentaram-se abaixo daqueles considerados como adequados para o referido estádio fenológico, sem contudo atingir o nivel de deficiência. Já os teores foliares de $\mathrm{K}, \mathrm{Ca}, \mathrm{Mg}$ e $S$ encontraram-se dentro dos limites de suficiência para a cultura (Ambrosano et al., 1996; Malavolta et al.; 1997 e Embrapa, 1998).

Embora considerados baixos, os teores foliares de $\mathrm{N}$ e $\mathrm{P}$ obtidos foram bastante semelhantes aos encontrados em diversos trabalhos (Mascarenhas et al., 1980; Ramos et al., 1989; Tanaka et al., 1992 e Mascarenhas et al, 1996).

Em relação à época de amostragem (Tabela 38), observou-se que do estádio V4 para R1 os teores foliares de $\mathrm{N}$ e $\mathrm{P}$ aumentaram, $\mathrm{K}$ e Ca sofreram redução e $\mathrm{Mg}$ e S se mantiveram. Em relação a variação ocorrida de R1 para R4 observou-se que todos os macronutrientes sofreram redução nos níveis foliares.

Tabela. 38 Comparação entre médias dos teores foliares de macronutrientes nos estádios V4, R1 e R4 do experimento de casa de vegetação (Época 2).

\begin{tabular}{|c|c|c|c|c|c|c|}
\hline Estádio & $\overline{\mathrm{N}}$ & $\bar{P}$ & $\bar{K}$ & $\overline{\mathrm{Ca}}$ & $\overline{\mathrm{Mg}}$ & $\bar{S}$ \\
\hline & \multicolumn{6}{|c|}{.................................. $\mathrm{g} \mathrm{kg}^{-1}$} \\
\hline V4 & $31,2 b^{1}$ & $1,9 b$ & $23,8 a$ & $14,3 a$ & $4,4 a$ & $2,2 a$ \\
\hline R1 & $37,3 a$ & $2,2 a$ & $17,2 b$ & $11,8 b$ & $4,4 a$ & $2,2 a$ \\
\hline R4 & $27,7 \mathrm{c}$ & $1,3 c$ & $7,4 c$ & $9,4 c$ & $2,5 b$ & $1,3 b$ \\
\hline $\begin{array}{l}\text { Valor de F } \\
\text { C.V. }(\%)\end{array}$ & $\begin{array}{c}94,22^{\star \star} \\
9,84\end{array}$ & $\begin{array}{c}172,12^{\star \star} \\
12,05\end{array}$ & $\begin{array}{c}410,08^{\star \star} \\
16,02\end{array}$ & $\begin{array}{l}74,86^{\star \star} \\
15,17\end{array}$ & $\begin{array}{c}145,98^{\star \star} \\
14,85\end{array}$ & $\begin{array}{c}114,21^{\star \star} \\
16,47\end{array}$ \\
\hline
\end{tabular}

O crescimento do sistema radicular tem ocorrência em praticamente durante todo o ciclo da planta de soja, cessando com o início da formação dos 
grãos. A formação de nódulos normalmente tem início dos 7-10 dias após a emergência da plântula. Sob condições favoráveis, entre 15-10 dias após a emergência, são visíveis e capazes de iniciar o fornecimento de nitrogênio à planta (Câmara, 1998). Assim, o aumento verificado nos niveis de $\mathrm{N}$, do estádio V4 para o R1, pode ser devido ao maior suprimento do elemento a partir dos nódulos radiculares.

O fósforo é um elemento absorvido pela planta principalmente pelo processo de difusão, exigindo portanto proximidade entre a raiz e o fertilizante. Desse modo, o aumento do sistema radicular do estádio V4 para o R1 contribuiu para maior absorção de $P$ pela planta, uma vez que o fertilizante foi distribuído homogeneamente por todo o volume de terra do vaso, explicando o aumento entre estas duas fases.

$\mathrm{O}$ maior valor de $\mathrm{K}$ encontrado no estádio $\mathrm{V} 4$ em relação ao $\mathrm{R} 1$, pode ser explicado pela absorção de luxo deste nutriente pela planta em função da adubação de cobertura feita poucos dias antes da coleta das folhas. Além disso, o aumento da parte aérea ocorrido entre uma amostragem e outra exigiu a redistribuição deste elemento e, consequentemente, sua diluição e redução dos niveis foliares observados no estádio R4.

Mais da metade da matéria seca acumulada é produzida posteriormente ao florescimento (R1), sendo o período de maior crescimento e exigência de macronutrientes àquele compreendido entre 0 início do florescimento e o "enchimento" dos grãos (Bataglia e Mascarenhas, 1977).

Estes autores observaram que cerca da metade das quantidades totais do $\mathrm{N}, \mathrm{P}$ e K, contidas na planta, foram absorvidas após o início do desenvolvimento dos grãos, havendo decréscimos na concentração de nutrientes nas partes vegetativas à medida que evoluía o processo de formação dos grãos. Os teores de $\mathrm{N}$ e $\mathrm{K}$ foram os que mais decresceram, ao contrário do Ca e do Mg. Essas observações podem justificar a redução das médias dos teores foliares dos macronutrientes (Tabela 38) obtidos no estádio R4 em relação ao estádio R1. 
O teor foliar de N, observado em R4, foi superior e, o de K, inferior aos obtidos por Hanway \& Weber (1971) na fase de maturidade fisiológica das sementes (estádio R7); o de $\mathrm{P}$, foi semelhante. Comparados aos dados de Malavolta et al. (1980), verificou-se que os teores obtidos de N, P, K e Ca foram inferiores e, os de $\mathrm{Mg}$ e $\mathrm{S}$, semelhantes aos encontrados pelos autores nas duas cultivares de soja que utilizaram.

A redução nos teores de $\mathrm{Ca}$, do estádio $\mathrm{R} 1$ para o $\mathrm{R} 4$, ao contrário do observado no experimento 1 (época 1), pode ser explicada em razão da menor intensidade transpiratória ocorrida nesta época, uma vez que o Ca na seiva do xilema é translocado em direção ascendente, no sentido do fluxo transpiratório, cuja intensidade controla a taxa de translocação de Ca para a parte aérea (Mengel \& Kirkby , 1987), resultando assim em alterações nos níveis foliares do elemento.

Entre os micronutrientes não foram verificadas diferenças em função dos tratamentos, nos estádios V4 e R1 (Tabelas 39 e 40). Entretanto, no estádio R4, encontraram-se diferenças entre os teores foliares de boro, ferro e manganês (Tabela 41).

Os teores foliares de B, Fe e Zn encontrados no estádio R1 situaramse dentro de valores adequados, enquanto que os teores de $\mathrm{Cu}$ apresentaramse em níveis considerados baixos pelos critérios de Ambrosano et al. (1996), Malavolta et al. (1997) e Embrapa (1998). Esses níveis foram bastante semelhantes aos encontrados no referido estádio, no primeiro experimento (época 1).

No estádio $\mathrm{R} 1$, os teores de $\mathrm{B}, \mathrm{Fe}$ e $\mathrm{Zn}$ foram similares aos verificados por Mascarenhas et al. (1980), Galrão (1991), Tanaka et. al. (1992b) e Lazarini (1995). 


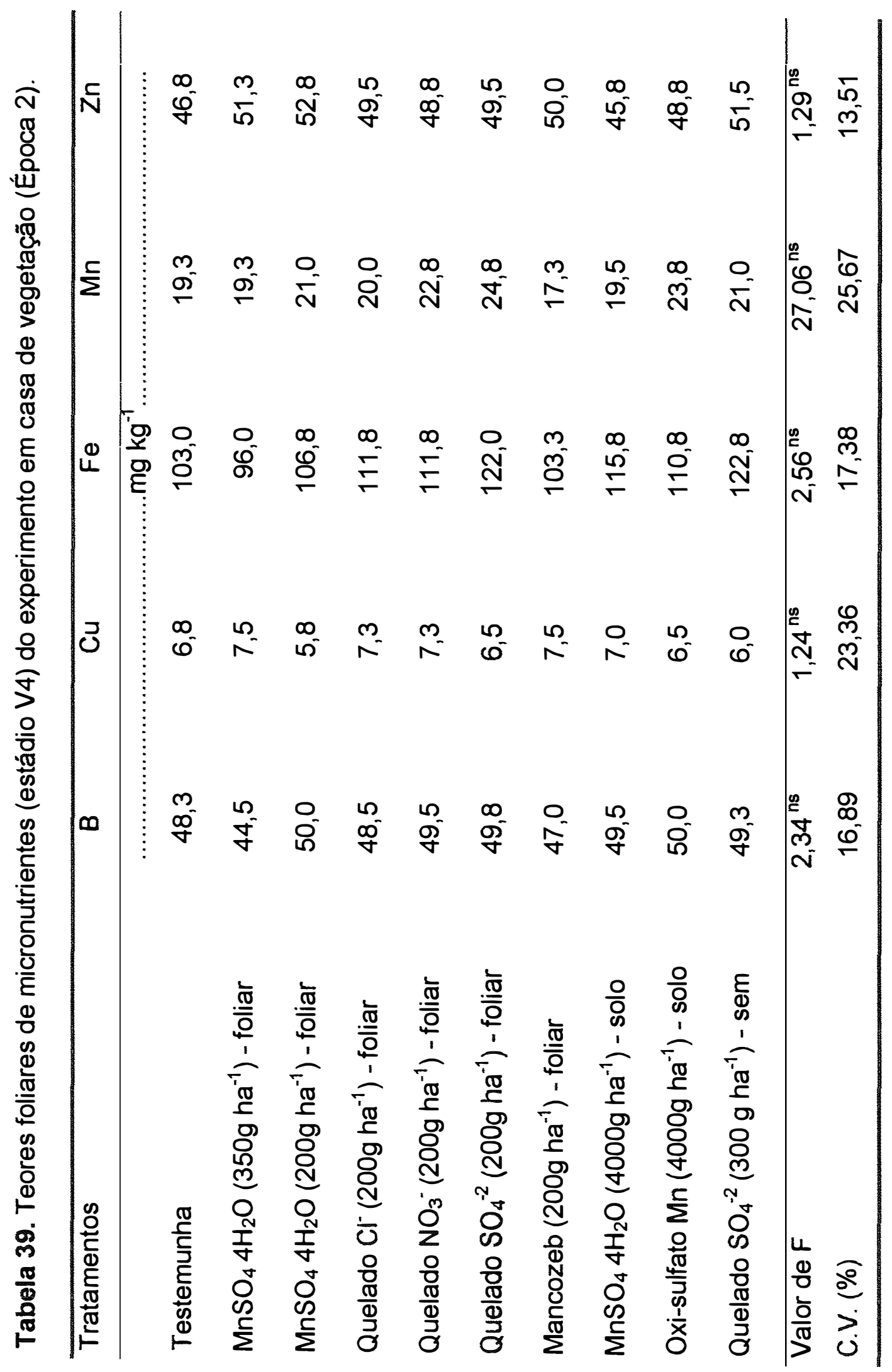




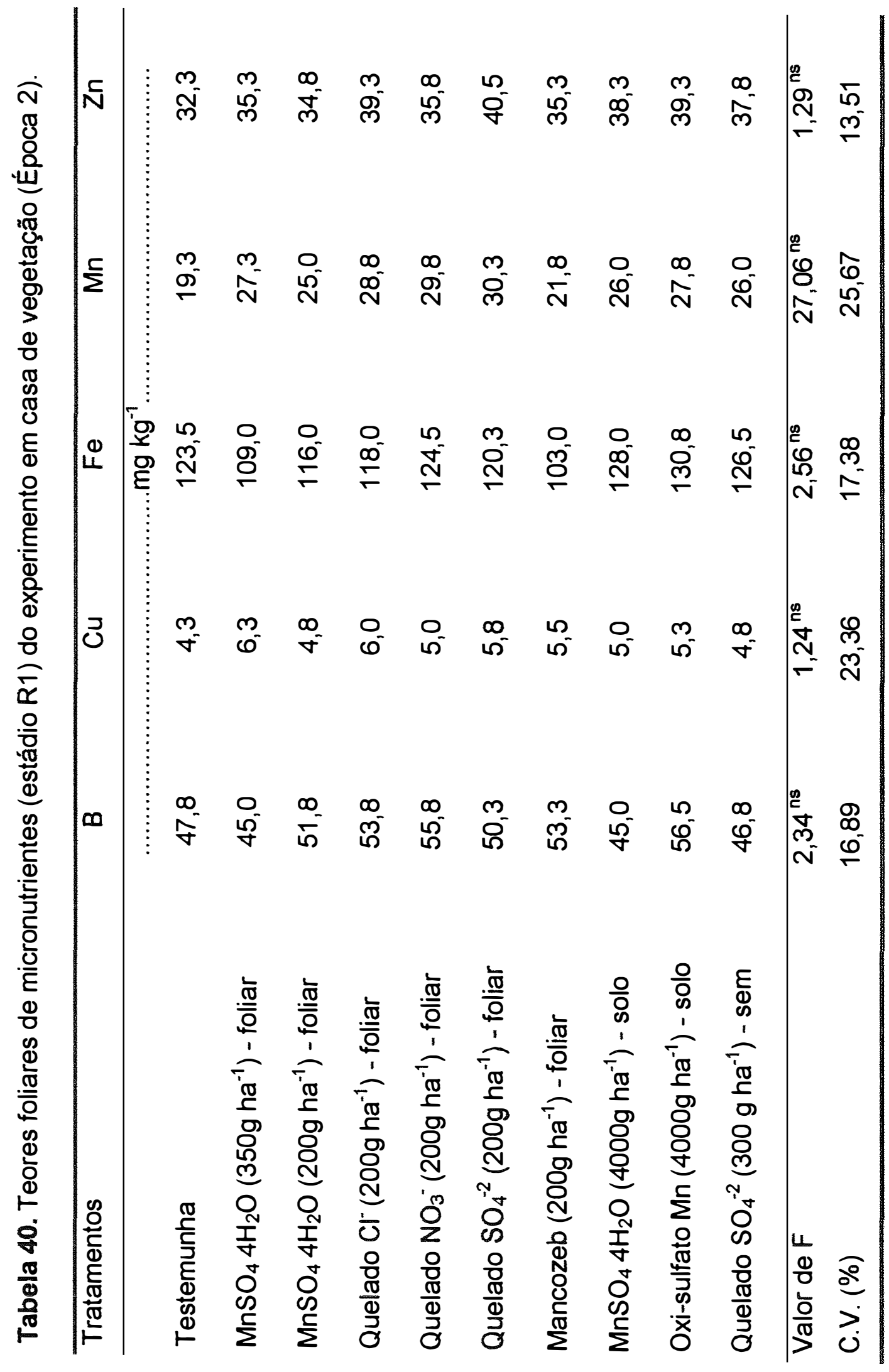




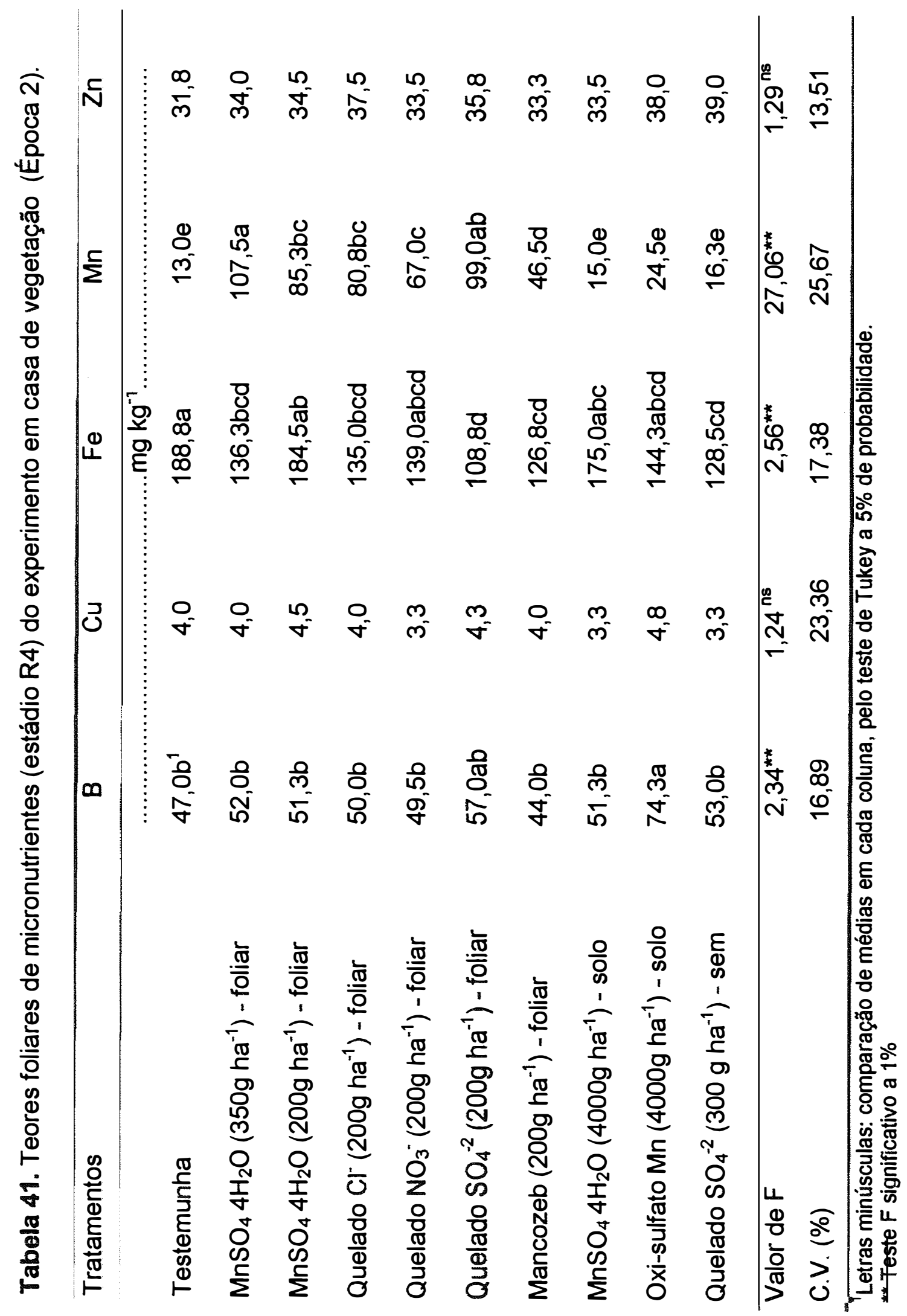


Em relação ao cobre, embora tendo apresentado teores considerados baixos, pelo critério mencionado acima, observou-se pela literatura ocorrência de níveis muito semelhantes aos obtidos (Silva et al., 1986; Galrão, 1991 e Lazarini, 1995). Este último autor encontrou níveis foliares de $\mathrm{Cu}$ menores em semeaduras mais tardias (conforme já discutido na época 1), o que pode ter contribuído para a redução dos seus teores na época 2 .

Os níveis foliares de manganês, no estádio $R 1$, não apresentaram diferenças em função dos tratamentos. Numericamente, apenas a testemunha apresentou teores abaixo do nível crítico $\left(20 \mathrm{mg} \mathrm{kg}^{-1}\right)$.

No segundo experimento (época 2), os valores de Mn (em R1) foram, aparentemente, maiores que os observados no primeiro (época 1), mesmo na testemunha e nos tratamentos via solo e semente. Este fato pode ter revelado uma certa influência da época de plantio sobre o teor foliar de manganês, que deve estar relacionada à menor demanda funcional por este nutriente, conforme observaram Ghazali \& Cox, (1981). Aparentemente, ao contrário do Cu, os teores de Mn tenderam a ser maiores em semeaduras mais tardias, como também observou Lazarini (1995).

No estádio R4, foram encontradas diferenças em função dos tratamentos nos níveis foliares de B, Fe e Mn (Tabela 41).

Em relação ao $\mathrm{B}$, verificou-se maiores teores foliares nas plantas tratadas com oxi-sulfato de $\mathrm{Mn}$ (4000 $\mathrm{g} \mathrm{ha}^{-1}$ via solo). O resultado pode estar relacionado à presença de $B$ no produto utilizado (Tabela 6). Na época 1 , o mesmo fenômeno pode não ter se verificado pelo fato de um possível efeito de diluição em decorrência de maior produção de massa vegetal em comparação à época 2.

Os teores foliares de $\mathrm{Mn}$ e de Fe sofreram variação em função dos tratamentos no estádio R4 (Tabela 41).

Todos os produtos utilizados via foliar levaram a teores de $\mathrm{Mn}$ superiores aos das plantas da testemunha e, também, àquelas tratadas com manganês via solo e via semente, as quais não diferiram da testemunha. 
Dentre as fontes de manganês fornecidas via foliar, observou-se que os maiores niveis estavam presentes nas plantas tratadas com $\mathrm{MnSO}_{4} 4 \mathrm{H}_{2} \mathrm{O}$ (na dose de $350 \mathrm{~g} \mathrm{ha}^{-1}$ ) e quelado $\mathrm{SO}_{4}^{-2}$ (na dose de $200 \mathrm{~g} \mathrm{ha}^{-1}$ ), os quais ficaram muito próximos dos teores encontrados naquelas que foram tratadas com quelado $\mathrm{Cl}^{-}, \mathrm{MnSO}_{4} 4 \mathrm{H}_{2} \mathrm{O}$ e quelado $\mathrm{NO}_{3}^{-}$(todos na dose de $200 \mathrm{~g} \mathrm{ha}^{-1}$ ). Os niveis foliares das plantas tratadas com mancozeb ficaram abaixo dos demais tratamentos via foliar.

Assim como no primeiro experimento (época 1), os tratamentos via solo e via semente não foram suficientes para manter os teores de Mn, em R4, superiores aos da testemunha, mostrando, novamente, que para o parâmetro nivel foliar a aplicação de Mn via solo foi menos eficiente que à foliar, estando de acordo com trabalhos obtidos por Randall et al. (1975) e Volkweiss (1991).

Os niveis foliares de $\mathrm{Fe}$ encontrados parecem ter sofrido ligeira variação, com algumas exceções, de modo inversamente proporcional aos níveis de $\mathrm{Mn}$, podendo indicar um possível efeito interiônico (inibição competitiva) do Mn sobre o Fe (Malavolta et al., 1997).

A comparação de médias dos teores foliares de micronutrientes entre os estádios V4, R1 e R4 (Tabela 42) mostrou que os teores de B não sofreram alteração; quanto ao $\mathrm{Fe}$, observou-se que não houve variação entre o estádio V4 para o R1 sendo encontrado, no entanto, aumento no estádio R4 em relação aos primeiros. Já os teores de $\mathrm{Cu}$, reduziram-se do estádio V4 para R1 e de R1 para R4; para o Zn, observou-se redução de V4 para R1 e os níveis se mantiveram de R1 para R4. As médias dos teores foliares de Mn aumentaram de V4 para R1 e de R1 para R4, influenciadas pelo fornecimento deste elemento pelos tratamentos, conforme já discutido anteriormente. 
Tabela. 42 Comparação entre médias dos teores foliares de micronutrientes nos estádios V4, R1 e R4 do experimento de casa de vegetação (Época 2).

\begin{tabular}{|c|c|c|c|c|c|}
\hline Estádio & $\bar{B}$ & $\overline{\mathrm{Cu}}$ & $\overline{\mathrm{Fe}}$ & $\overline{M n}$ & $\overline{Z n}$ \\
\hline & .. & …….. & $\mathrm{mg} \mathrm{kg}^{-1}$ & . & $\cdots$ \\
\hline V4 & 48,6 & $6,8 a^{1}$ & $110,4 b$ & $20,8 \mathrm{c}$ & $49,4 a$ \\
\hline R1 & 50,6 & $5,2 b$ & $119,9 b$ & $26,2 b$ & $36,8 b$ \\
\hline R4 & 52,9 & $3,9 c$ & $146,7 a$ & $55,5 a$ & $35,1 b$ \\
\hline $\begin{array}{l}\text { Valor de F } \\
\text { C.V. (\%) }\end{array}$ & $\begin{array}{c}2,53^{\text {ns }} \\
16,89\end{array}$ & $\begin{array}{l}53,53^{\star \star} \\
23,36\end{array}$ & $\begin{array}{l}29,69^{\star \star} \\
17,38\end{array}$ & $\begin{array}{c}109,15^{\star \star} \\
31,84\end{array}$ & $\begin{array}{l}82,34^{\star \star} \\
13,51\end{array}$ \\
\hline
\end{tabular}

Embora o cobre seja um elemento cuja mobilidade em relação à redistribuição seja limitada, a redução de seus teores foliares, entre os estádios, pode estar indicando a ocorrência de migração do nutriente das folhas para os grãos. Nesse sentido, Tanaka et al. (1993) observaram que a redistribuição de cobre na planta dependeu de sua concentração.

O comportamento do ferro na época 2 foi semelhante ao da época 1 , confirmando o fornecimento suficiente desse nutriente do solo para a planta e um eventual acúmulo nas folhas amostradas devido à sua baixa mobilidade quanto a redistribuição.

As médias dos teores foliares de zinco, na época 2, foram semelhantes às encontradas nos mesmos estádios no primeiro experimento (época 1). A redução dos níveis foliares em R1 e R4, em comparação ao V4, pode ser explicada pelo efeito de diluição do zinco em função do maior desenvolvimento vegetativo da planta.

Os teores foliares de $\mathrm{Cu}$ e $\mathrm{Fe}$ foram menores, enquanto que os de $\mathrm{Be}$ $\mathrm{Zn}$ foram semelhantes aos encontrados por Malavolta et al. (1980), no período de formação de vagens da soja. 


\subsubsection{Teor de clorofila nas folhas}

Os resultados verificados pelas leituras realizadas nos estádios V4, R1 e R4, pelo aparelho clorofilômetro (teor de pigmento), encontram-se na Tabela 43.

Tabela 43. Avaliação do teor de pigmento nas folhas, obtido pelo aparelho clorofilômetro, no experimento de casa de vegetação (Época 2)

\begin{tabular}{|c|c|c|c|c|}
\hline \multirow[t]{2}{*}{ Tratamentos } & \multicolumn{4}{|c|}{ Leitura do teor de pigmento } \\
\hline & V4 & R1 & R4 & MEDIA \\
\hline & \multicolumn{4}{|c|}{ 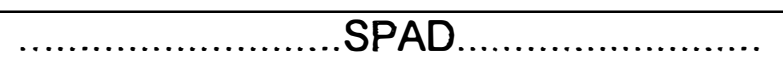 } \\
\hline Testemunha & $28,8 \mathrm{aC}^{1}$ & $41,0 \mathrm{aA}$ & $37,0 \mathrm{bB}$ & $35,6 a$ \\
\hline $\mathrm{MnSO}_{4} 4 \mathrm{H}_{2} \mathrm{O}\left(350 \mathrm{~g} \mathrm{ha}^{-1}\right)$ - foliar & $28,9 a B$ & $41,7 \mathrm{aA}$ & $41,2 \mathrm{abA}$ & $37,2 a$ \\
\hline $\mathrm{MnSO}_{4} 4 \mathrm{H}_{2} \mathrm{O}\left(200 \mathrm{~g} \mathrm{ha}^{-1}\right)$ - foliar & $28,9 a B$ & $41,5 \mathrm{aA}$ & $38,4 a b A$ & $36,3 a$ \\
\hline Quelado $\mathrm{Cl}^{-}\left(200 \mathrm{~g} \mathrm{ha}^{-1}\right)$ - foliar & $28,8 a B$ & $39,5 \mathrm{aA}$ & $42,1 \mathrm{aA}$ & $36,8 a$ \\
\hline Quelado $\mathrm{NO}_{3}^{-}\left(200 \mathrm{~g} \mathrm{ha}^{-1}\right)$ - foliar & $29,1 \mathrm{aB}$ & $41,0 \mathrm{aA}$ & $39,3 a b A$ & $36,5 a$ \\
\hline Quelado $\mathrm{SO}_{4}^{-2}\left(200 \mathrm{~g} \mathrm{ha}^{-1}\right)$ - foliar & $28,2 \mathrm{aB}$ & $40,4 a A$ & $42,4 a A$ & $37,0 a$ \\
\hline Mancozeb (200 g ha $\left.{ }^{-1}\right)$ - foliar & $27,7 \mathrm{aB}$ & $41,2 \mathrm{aA}$ & $40,7 a b A$ & $36,5 a$ \\
\hline $\mathrm{MnSO}_{4} 4 \mathrm{H}_{2} \mathrm{O}\left(4000 \mathrm{~g} \mathrm{ha}^{-1}\right)$ - solo & $28,5 a B$ & $41,9 a A$ & $40,4 a b A$ & $36,9 a$ \\
\hline Oxi-sulfato Mn (4000g ha-1) - solo & $30,5 a B$ & $40,4 a A$ & $40,5 a b A$ & $37,1 \mathrm{a}$ \\
\hline Quelado $\mathrm{SO}_{4}^{-2}\left(300 \mathrm{~g} \mathrm{ha}^{-1}\right)$ - sem. & $27,4 a B$ & $40,7 \mathrm{aA}$ & $42,3 \mathrm{aA}$ & $36,8 a$ \\
\hline MÉDIA & $28,7 \mathrm{~B}$ & $40,9 A$ & $40,4 \mathrm{~A}$ & \\
\hline $\begin{array}{l}\text { Valor de F } \\
\text { C.V. (\%) }\end{array}$ & $\begin{array}{l}1,77^{\star \star} \\
5,53\end{array}$ & & & \\
\hline
\end{tabular}

Entre os estádios amostrados, observou-se que todos os tratamentos tiveram aumento na coloração verde do estádio V4 para o R1 e não houve 
diferença entre o estádio R1 para o R4, com exceção da testemunha, que apresentou redução na leitura no estádio $\mathrm{R} 4$ em relação ao R1.

Foram verificadas diferenças de leituras entre os tratamentos apenas no estádio R4. Neste estádio, as plantas tratadas com quelado $\mathrm{Cl}^{-}$(via foliar, $200 \mathrm{~g} \mathrm{ha}^{-1}$ ), quelado $\mathrm{SO}_{4}^{-2}$ (via foliar, $200 \mathrm{~g} \mathrm{ha}^{-1}$ ) e quelado $\mathrm{SO}_{4}^{-2}$ (via semente, $300 \mathrm{~g} \mathrm{ha}^{-1}$ ) apresentaram leituras superiores à testemunha, indicando maior coloração verde, o que pode estar relacionado com a redução da clorose, influenciada pelo suprimento de manganês. Entretanto, assim como foi observado na época 1, não foi possivel determinar-se correlação entre os teores foliares de Mn (Tabela 41) e as leituras do teor de pigmento, no estádio R4.

Os teores de clorofila (Tabela 44) foram calculados a partir das leituras do teor de pigmento, aplicando-se a equação proposta por Barnes et al. (1992). Os resultados obtidos assemelharam-se aos encontrados nas leituras de pigmento. No estádio R4, as plantas tratadas com quelado $\mathrm{Cl}^{-}$(via foliar, $200 \mathrm{~g}$ $\mathrm{ha}^{-1}$ ), quelado $\mathrm{SO}_{4}^{-2}$ (via foliar, $200 \mathrm{~g} \mathrm{ha}^{-1}$ ) e quelado $\mathrm{SO}_{4}^{-2}$ (via semente, $300 \mathrm{~g}$ $\mathrm{ha}^{-1}$ ) apresentaram teores de clorofila superiores à testemunha.

Esses resultados indicaram que o sistema de leitura de pigmento, por detectar variações nos teores de clorofila, tem potencial para avaliação preliminar do estado nutricional da planta em relação ao $\mathrm{Mn}$, uma vez que os cloroplastos são as organelas da célula mais sensiveis à deficiência desse elemento (Homann, 1967). 
Tabela 44. Concentração de clorofila nas folhas, no experimento de casa de vegetação (Época 2).

\begin{tabular}{|c|c|c|c|c|}
\hline \multirow[t]{2}{*}{ Tratamentos } & \multicolumn{4}{|c|}{ Concentração de clorofila } \\
\hline & V4 & R1 & R4 & MÉDIA \\
\hline & \multicolumn{4}{|c|}{ 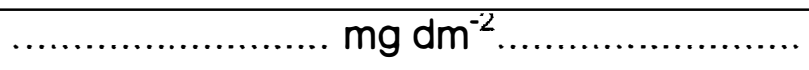 } \\
\hline Testemunha & $2,72 \mathrm{aC}^{1}$ & $3,93 a A$ & $3,53 \mathrm{bB}$ & $3,39 a$ \\
\hline $\mathrm{MnSO}_{4} 4 \mathrm{H}_{2} \mathrm{O}\left(350 \mathrm{~g} \mathrm{ha}^{-1}\right)$ - foliar & $2,72, a B$ & $4,00 a A$ & $3,95 a b A$ & $3,55 a$ \\
\hline $\mathrm{MnSO}_{4} 4 \mathrm{H}_{2} \mathrm{O}\left(200 \mathrm{~g} \mathrm{ha}^{-1}\right)$ - foliar & $2,73 a \mathrm{aB}$ & $3,98 \mathrm{aA}$ & $3,67 \mathrm{bA}$ & $3,46 a$ \\
\hline Quelado $\mathrm{Cl}^{-}\left(200 \mathrm{~g} \mathrm{ha}^{-1}\right)$ - foliar & $2,70 \mathrm{aB}$ & $3,78 \mathrm{aA}$ & $4,04 a A$ & $3,50 a$ \\
\hline Quelado $\mathrm{NO}_{3}^{-}\left(200 \mathrm{~g} \mathrm{ha}^{-1}\right)$ - foliar & $2,74 a \mathrm{aB}$ & $3,93 a A$ & $3,76 a b A$ & $3,48 a$ \\
\hline Quelado $\mathrm{SO}_{4}^{-2}\left(200 \mathrm{~g} \mathrm{ha}^{-1}\right)$ - foliar & $2,66 a \mathrm{~B}$ & $3,87 a A$ & $4,07 a A$ & $3,53 a$ \\
\hline Mancozeb (200 g ha-1) - foliar & $2,61 \mathrm{aB}$ & $3,95 a A$ & $3,90 a b A$ & $3,48 a$ \\
\hline $\mathrm{MnSO}_{4} 4 \mathrm{H}_{2} \mathrm{O}\left(4000 \mathrm{~g} \mathrm{ha}^{-1}\right)$ - solo & $2,69 a \mathrm{~B}$ & $4,02 a A$ & $3,87 a b A$ & $3,53 a$ \\
\hline Oxi-sulfato Mn (4000g ha $\left.{ }^{-1}\right)$ - solo & $2,89 a B$ & $3,87 a A$ & $3,88 \mathrm{abA}$ & $3,54 a$ \\
\hline Quelado $\mathrm{SO}_{4}^{-2}\left(300 \mathrm{~g} \mathrm{ha}^{-1}\right)$ - sem. & $2,58 \mathrm{aB}$ & $3,90 \mathrm{aA}$ & $4,06 a A$ & $3,51 a$ \\
\hline MÉDIA & $2,71 \mathrm{~B}$ & $3,92 \mathrm{~A}$ & $3,87 \mathrm{~A}$ & \\
\hline $\begin{array}{l}\text { Valor de F } \\
\text { C.V. }(\%)\end{array}$ & $\begin{array}{l}0,74^{*} \\
5,78\end{array}$ & & & \\
\hline
\end{tabular}

\subsubsection{Produção de grãos}

O número e o percentual de vagens com $0,1,2$ e 3 grãos e grãos chochos encontrados estão apresentados na Tabela 45.

$\mathrm{Na}$ época 2, a produção de vagens parece ter sido inferior à época 1. Esta tendência também foi observada por Medina (1994) e Lazarini (1995) os quais constataram que o retardamento na semeadura induziu a formação de menor número de vagens por planta. 


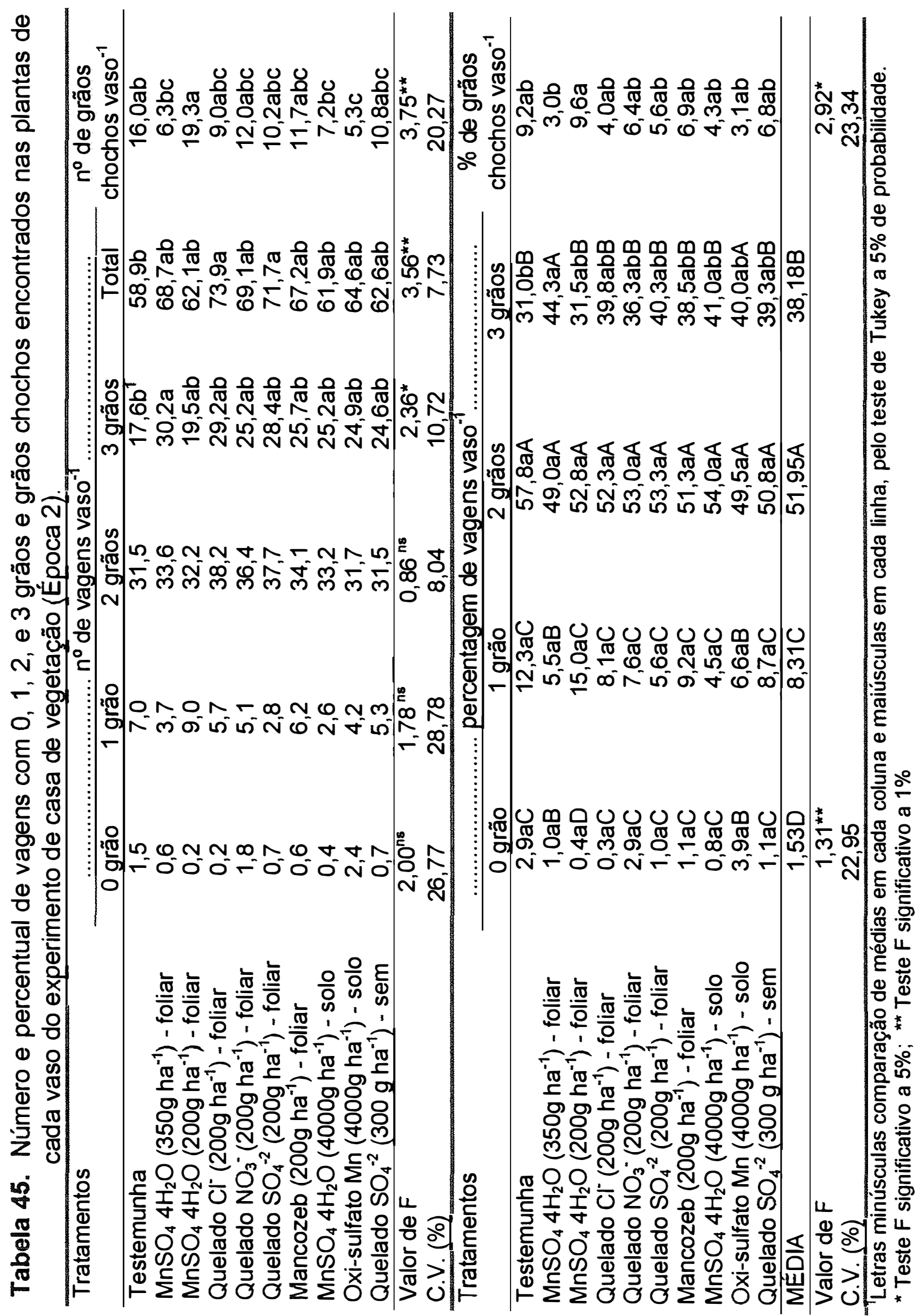


A análise dos resultados obtidos revelaram ocorrência de diferenças entre os tratamentos para o número de vagens de 3 grãos, número total de vagens e número de grãos chochos.

As plantas tratadas com $\mathrm{MnSO}_{4} \quad 4 \mathrm{H}_{2} \mathrm{O}$ (350 $\mathrm{g} \mathrm{ha}^{-1}$, via foliar) apresentaram maior número e percentagem de vagens com 3 grãos enquanto que os menores valores foram observados na testemunha.

Os tratamentos quelado $\mathrm{Cl}^{-}$e quelado $\mathrm{SO}_{4}^{-2}$ (200 $\mathrm{g} \mathrm{ha}^{-1}$, via foliar) proporcionaram plantas com o maior número de vagens produzidas, sendo que as plantas que não receberam nenhum tipo de suplementação de $\mathrm{Mn}$ (testemunha) apresentaram a menor produção total de vagens.

$\mathrm{O}$ fornecimento de manganês via foliar na maior dose $\left(\mathrm{MnSO}_{4} 4 \mathrm{H}_{2} \mathrm{O}\right.$ $350 \mathrm{~g} \mathrm{ha}^{-1}$ ) resultou também em plantas com menor percentual de grãos chochos.

Assim, ao contrário da época 1, a aplicação via foliar de manganês em V4 e R1, na época 2, podem ter propiciado melhor estado nutricional para este elemento e, consequentemente, atendendo melhor a demanda para formação de vagens.

Os resultados revelaram, portanto, que o fornecimento de manganês, através das fontes citadas, proporcionou formação de maior número de vagens com maior produção de grãos por vagem, podendo refletir em produção superior de grãos.

Os resultados de produção, expressos em número e massa de grãos por vaso, encontram-se na Tabela 46. 
Tabela 46. Dados de produção de grãos do experimento de casa de vegetação (Época 2).

\begin{tabular}{|c|c|c|}
\hline \multirow[t]{2}{*}{ Tratamentos } & \multicolumn{2}{|c|}{ Produção de grãos } \\
\hline & $\mathrm{n}^{0}$ de grãos vaso-1 & $\ldots g$ vaso $^{-1} \ldots$ \\
\hline Testemunha & $125 d^{1}$ & $13,139 e$ \\
\hline $\mathrm{MnSO}_{4} 4 \mathrm{H}_{2} \mathrm{O}\left(350 \mathrm{~g} \mathrm{ha}^{-1}\right)$ - foliar & $162 a b$ & $17,677 a b$ \\
\hline $\mathrm{MnSO}_{4} 4 \mathrm{H}_{2} \mathrm{O}\left(200 \mathrm{~g} \mathrm{ha}^{-1}\right)$ - foliar & $134 \mathrm{~cd}$ & 14,417 cde \\
\hline Quelado $\mathrm{Cl}^{-}\left(200 \mathrm{~g} \mathrm{ha}^{-1}\right)$ - foliar & $170 a$ & $17,519 a b$ \\
\hline Quelado $\mathrm{NO}_{3}^{-}$(200 g ha-1) - foliar & 154abc & $17,382 \mathrm{abc}$ \\
\hline Quelado $\mathrm{SO}_{4}^{-2}\left(200 \mathrm{~g} \mathrm{ha}^{-1}\right)$ - foliar & $166 a b$ & $18,649 a$ \\
\hline Mancozeb (200 g ha-1) - foliar & $152 a b c$ & $16,692 \mathrm{abcd}$ \\
\hline $\mathrm{MnSO}_{4} 4 \mathrm{H}_{2} \mathrm{O}\left(4000 \mathrm{~g} \mathrm{ha}^{-1}\right)$ - solo & $145 a b c d$ & $15,492 \mathrm{bcde}$ \\
\hline Oxi-sulfato Mn (4000g ha-1) - solo & $145 a b c d$ & 14,795 cde \\
\hline Quelado $\mathrm{SO}_{4}^{-2}\left(300 \mathrm{~g} \mathrm{ha}^{-1}\right)$ - semente & $143 \mathrm{bcd}$ & 15,203 bcde \\
\hline Valor de F & $7,48^{\star \star}$ & $10,73^{\star \star}$ \\
\hline C.V. (\%) & 6,97 & 6,63 \\
\hline
\end{tabular}

\footnotetext{
Letras minúsculas: comparação em cada coluna, pelo teste de Tukey a $5 \%$ de probabilidade.

Teste F significativo a $1 \%$
}

Pode-se observar que o maior número de grãos foi proporcionado pelos tratamentos quelado $\mathrm{Cl}^{-}$(200 $\mathrm{g} \mathrm{ha}^{-1}$, via foliar), quelado $\mathrm{SO}_{4}^{-2}$ (200 g ha-1, via foliar) e $\mathrm{MnSO}_{4} 4 \mathrm{H}_{2} \mathrm{O}$ (350 $\mathrm{g} \mathrm{ha}^{-1}$, via foliar), enquanto que, o menor número, foi verificado para testemunha e $\mathrm{MnSO}_{4} 4 \mathrm{H}_{2} \mathrm{O}$ (200 $\mathrm{g} \mathrm{ha}^{-1}$, via foliar). Os demais tratamentos levaram a valores intermediários.

Com relação à massa de grãos, os tratamentos quelado $\mathrm{SO}_{4}^{-2}(200 \mathrm{~g}$ ha-1, via foliar), $\mathrm{MnSO}_{4} 4 \mathrm{H}_{2} \mathrm{O}$ (350 $\mathrm{g} \mathrm{ha}^{-1}$, via foliar) e quelado $\mathrm{Cl}^{-}\left(200 \mathrm{~g} \mathrm{ha}^{-1}\right.$, via foliar) foram os que propiciaram a maior massa de grãos. As plantas da testemunha produziram a menor massa, ao passo que produções intermediárias foram observadas em função dos demais tratamentos. Esse aumento de produção de grãos, obtido em função da aplicação foliar de 
manganês, também foi encontrado por Randall et al. (1975a), Zito et al. (1999) e Mann et al. (1999b).

Para o parâmetro produção de grãos, os produtos quelatizados aplicados via foliar apresentaram forte tendência de eficiência relativa superior à aplicação foliar do $\mathrm{MnSO}_{4} 4 \mathrm{H}_{2} \mathrm{O}\left(350 \mathrm{~g} \mathrm{ha}^{-1}\right.$ ), pois os primeiros proporcionaram produções muito próximas (estatisticamente iguais) a desse último, com aplicação de doses menores. Além disso, as plantas tratadas com $\mathrm{MnSO}_{4} 4 \mathrm{H}_{2} \mathrm{O}$ (200 $\mathrm{g} \mathrm{ha}^{-1}$ ) não alcançaram a mesma produção, embora tenham recebido a mesma dose de Mn que as fontes quelatizadas.

Os resultados obtidos indicaram, também, tendência de maior produção resultante da aplicação foliar, em comparação à aplicação via solo e via semente, confirmando 0 alto índice de utilização pela planta do nutriente aplicado via foliar, mesmo em menor dose, como observou também Volkweiss (1991).

A aplicação foliar no estádio V4 e R1 possibilitou aumento de produção, ao contrário da época 1, quando foi realizada apenas uma aplicação em R1, a qual não contribuiu para que se estabelecesse diferencial de produção entre os tratamentos. Este fato revelou que em condições de severa deficiência de $\mathrm{Mn}$, como as verificadas no experimento, o fornecimento do elemento na fase vegetativa e no início da fase reprodutiva, são fundamentais para que se estabeleça melhor correção no estado nutricional da planta em relação ao $\mathrm{Mn}$.

Ao contrário do observado para produção, o fornecimento de $\mathrm{Mn}$ não foi capaz de alterar a massa de 100 grãos (Tabela 47), mostrando que o efeito de produção está mais relacionado ao número de grãos produzidos. Esses resultados podem indicar provável influência do manganês na indução, desenvolvimento e pegamento das flores. 
Tabela 47. Dados de massa de 100 grãos do experimento de casa de vegetação (Época 2).

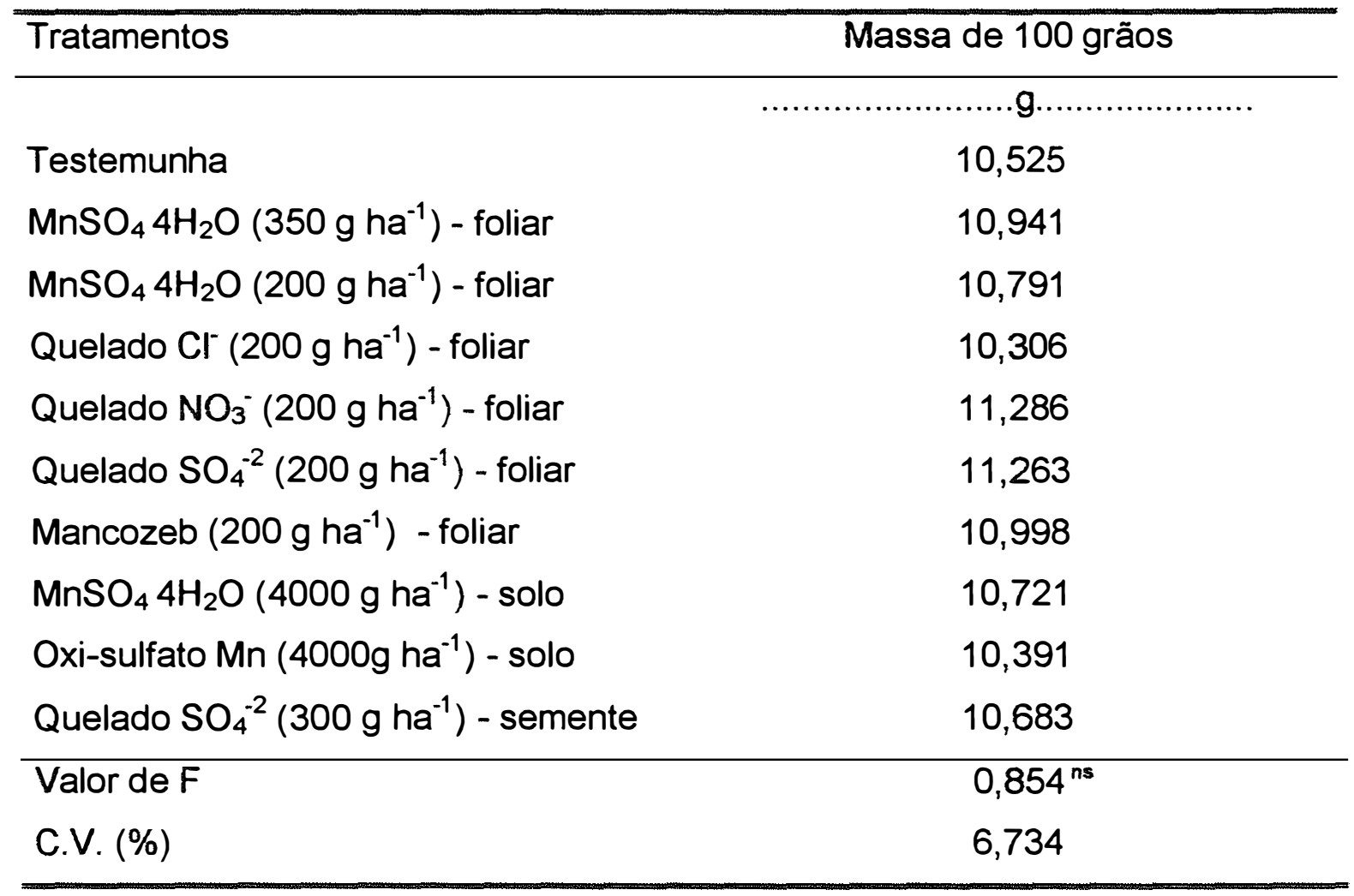

De acordo com Delouche (1980), as condições desfavoráveis podem acarretar principalmente redução na quantidade de sementes produzidas. Em função da sobrevivência da espécie, as poucas sementes originadas teriam a mesma qualidade do que aquelas produzidas por plantas cultivadas sob situações propícias. Assim, o menor suprimento de Mn, embora tenha afetado a produção, não foi suficiente para influenciar características qualitativas dos grãos produzidos. 


\subsubsection{Produção de matéria seca}

A produção total de matéria seca e das diferentes partes da planta, assim como o índice de colheita, estão apresentados na Tabela 48.

O estudo dos dados revelaram que a única parte isolada da planta, cuja produção de matéria seca apresentou diferença significativa em função dos tratamentos, foi o grão, conforme já discutido anteriormente. Entretanto, os resultados mostraram, também, que a produção total de matéria seca sofreu interferência dos tratamentos.

As plantas tratadas com aplicações foliares de $\mathrm{MnSO}_{4} 4 \mathrm{H}_{2} \mathrm{O}$ (350 $\left.\mathrm{g} \mathrm{ha}^{-1}\right)$, quelado $\mathrm{Cl}^{-}\left(200 \mathrm{~g} \mathrm{ha}^{-1}\right)$ e quelado $\mathrm{SO}_{4}^{-2}\left(200 \mathrm{~g} \mathrm{ha}^{-1}\right)$, apresentaram produção de matéria seca total maior que as plantas da testemunha. Estes resultados foram semelhantes aos observados por Abreu et al. (1994), que encontraram menor produção de matéria seca em plantas deficientes em manganês.

O cultivar utilizado mostrou-se susceptivel à época de semeadura, pois a produção de matéria seca das plantas semeadas na época 2 foi menor que a obtida na época 1. Esta influência também foi observada por Lazarini (1995).

Essa menor produção de matéria seca, na época 2, indicou que neste período também foi menor a velocidade de absorção dos nutrientes, diminuindo sua demanda funcional. Em tais condições, conforme verificaram Ghazali \& Cox (1981), reduz-se as possibilidades de ocorrência de deficiência nutricional, o que pode explicar os niveis foliares de manganês na testemunha (em R1) mais elevados na época 2 , do que na época 1 , vindo a confirmar o que havia sido apenas sugerido anteriormente.

A diferença verificada na produção de matéria seca pode estar relacionada, principalmente, à participação do elemento no processo de fotossíntese, metabolismo do nitrogênio e no seu papel como precursor de auxinas (hormônios de crescimento). 


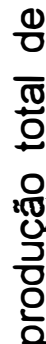

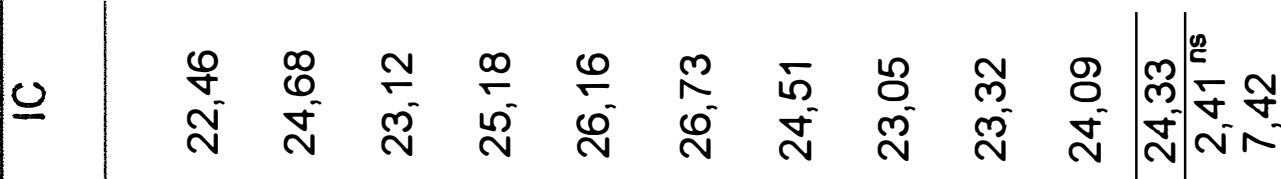

을

क्ष

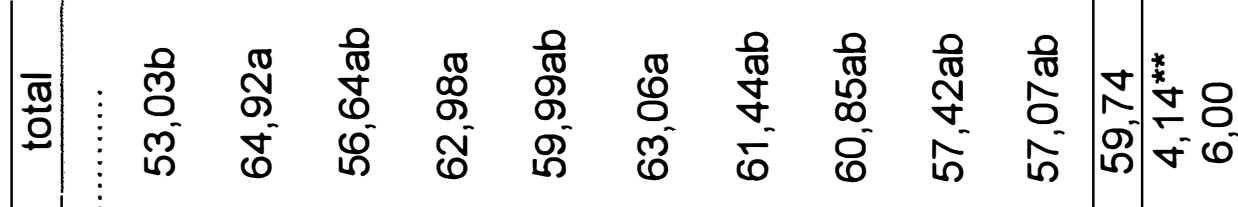

응

힝 프

क

क

○

क D

め)

ฮิ

능

ल U

ธั

오오

(ึ)

ํํำ

응

ரृ

ฒ 응

조

ब(ब

हั ठิ

ஸั ญ

임

을

인

응

ญ ฒ

요

웜

๑ั

$\infty$
$\frac{0}{0}$
$\frac{0}{0}$

U.

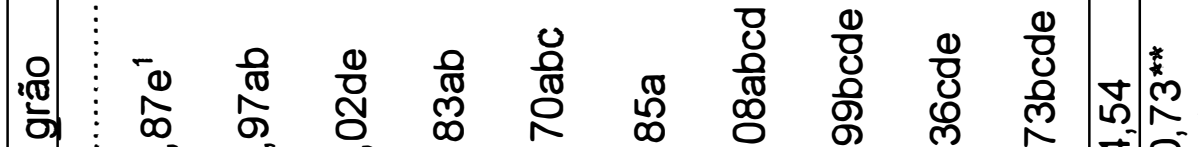

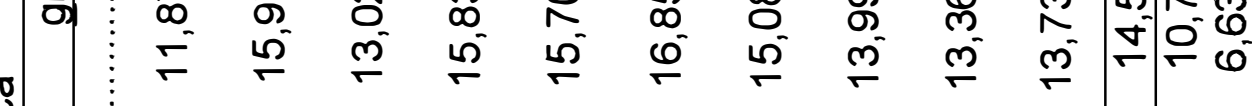

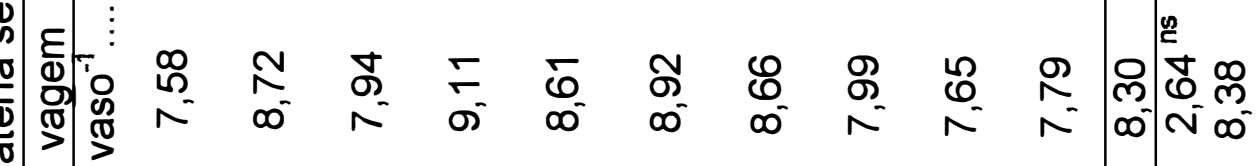

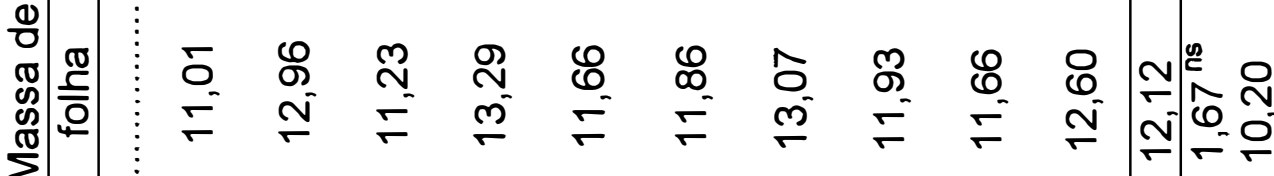

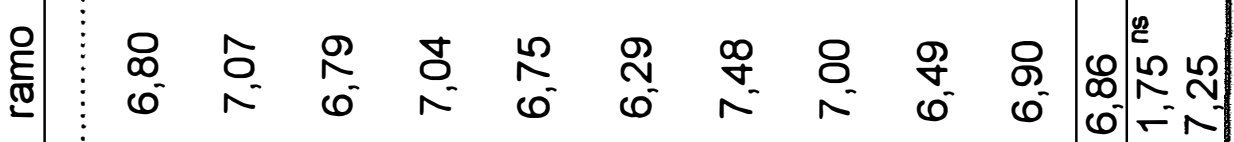

Nㅠ

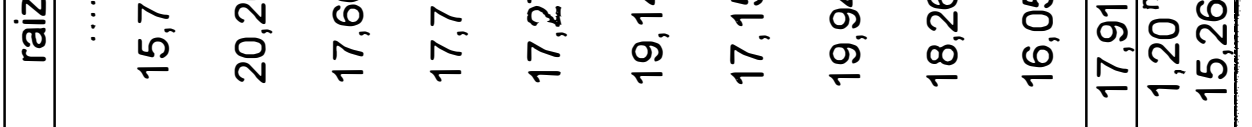

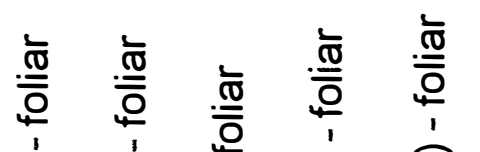

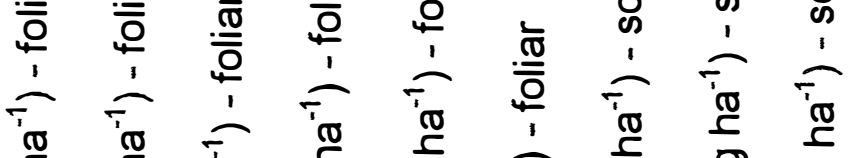

\%

(1)

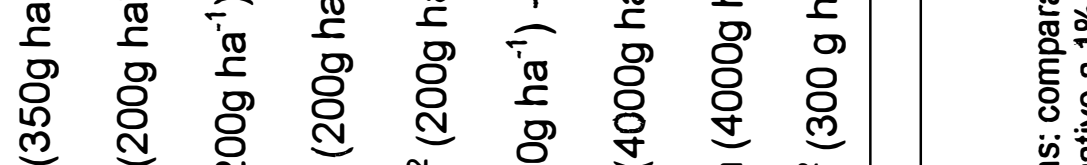

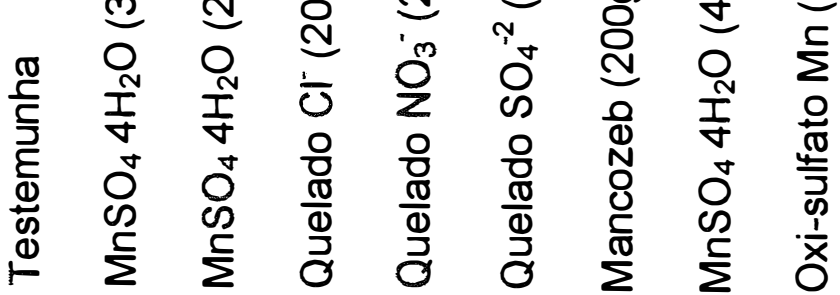

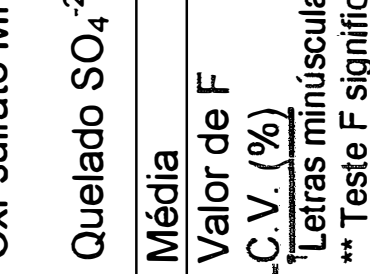

\& 
No entanto, a relação entre o produto colhido e a matéria seca total produzida (índice de colheita), não sofreu alteração em função dos tratamentos, indicando que as diferenças de produção de grãos encontradas foram, de certa forma, proporcionais à produção de matéria seca dos demais órgãos da planta.

\subsubsection{Teores de nutrientes nos grãos}

Os teores de macro e micronutrientes encontrados nos grãos estão apresentados nas Tabelas 49 e 50, respectivamente. Os resultados revelaram diferenças entre os tratamentos apenas para os teores de manganês.

Os resultados de macronutrientes obtidos na época 2 foram semelhantes aos observados por Mascarenhas et al. (1980), enquanto Oliveira et al. (1991) encontraram valores superiores para fósforo. Observou-se, também, que os valores verificados na época 2 , para $\mathrm{P}$ e $\mathrm{S}$, foram inferiores à concentração média de nutrientes nos grãos de soja, encontrada pela Embrapa (1998).

Em relação aos micronutrientes (Tabela 50), os valores obtidos para Fe foram semelhantes aos verificados por Oliveira et al. (1991), ao passo que os valores de $\mathrm{B}, \mathrm{Fe}$ e $\mathrm{Zn}$ ficaram próximos aos encontrados por Embrapa (1998). Os teores de Cu e Mn, no grão, foram menores do que os valores encontrados por esses autores.

Comparando-se os teores de macro e micronutrientes obtidos no grão, entre as épocas 1 e 2, observou-se que os valores de $\mathrm{N}, \mathrm{P}, \mathrm{S}$ e $\mathrm{Cu}$ apresentaram tendência de redução no segundo experimento.

A época de semeadura pode ter interferido nas concentrações de nutrientes no grão. Nesse sentido, Lazarini (1995) verificou que para alguns genótipos de soja os teores de N, P, S e Cu nos grãos foram menores em semeaduras mais tardias, quando encontrou teores de $51,9 \mathrm{~g} \mathrm{~kg}^{-1}$ para $\mathrm{N}, 3,7 \mathrm{~g}$ $\mathrm{kg}^{-1}$ para $\mathrm{P}, 1,6 \mathrm{~g} \mathrm{~kg}^{-1}$ para $\mathrm{S}$ e $5,1 \mathrm{mg} \mathrm{kg}^{-1}$ para $\mathrm{Cu}$. 


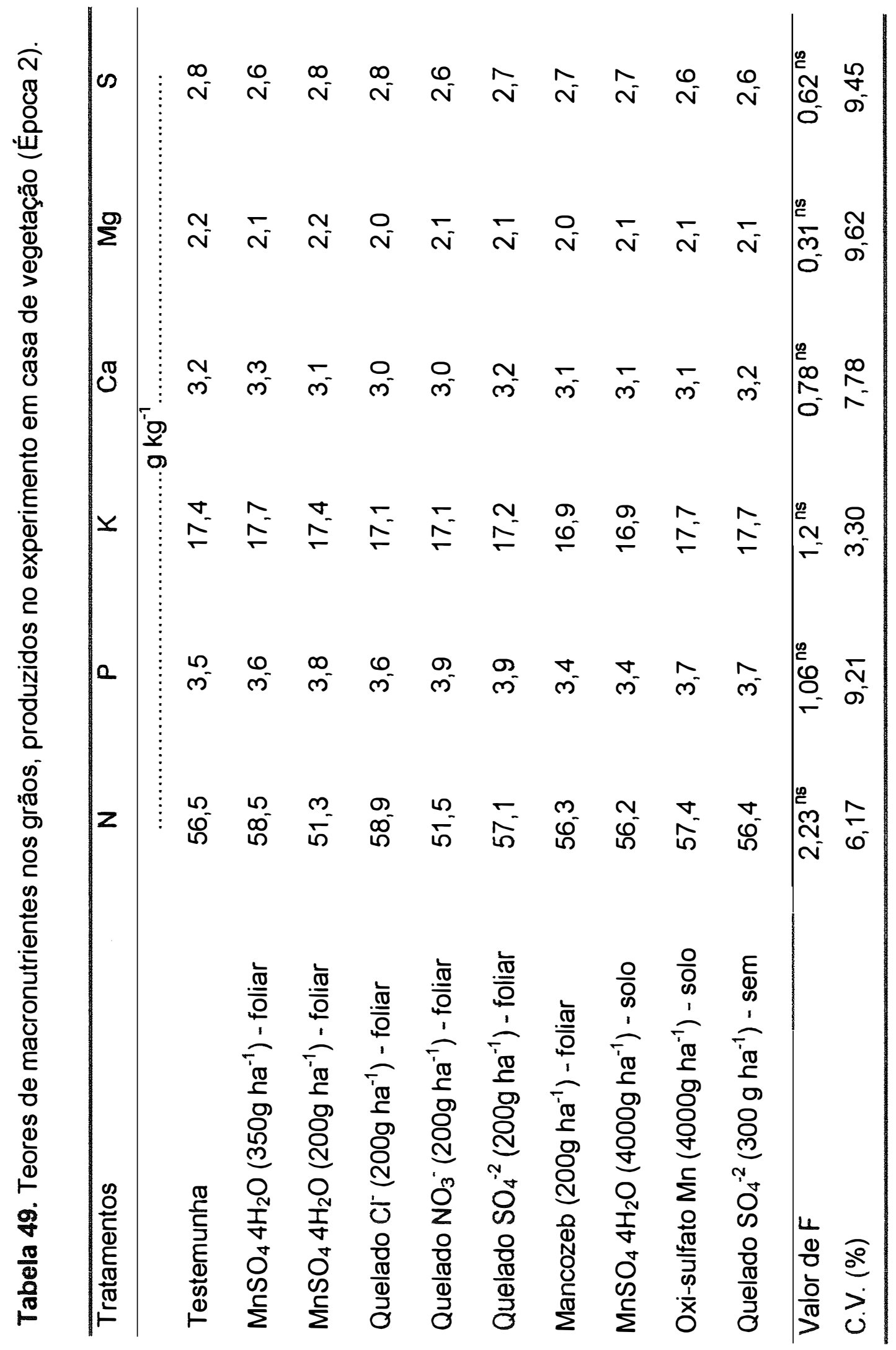




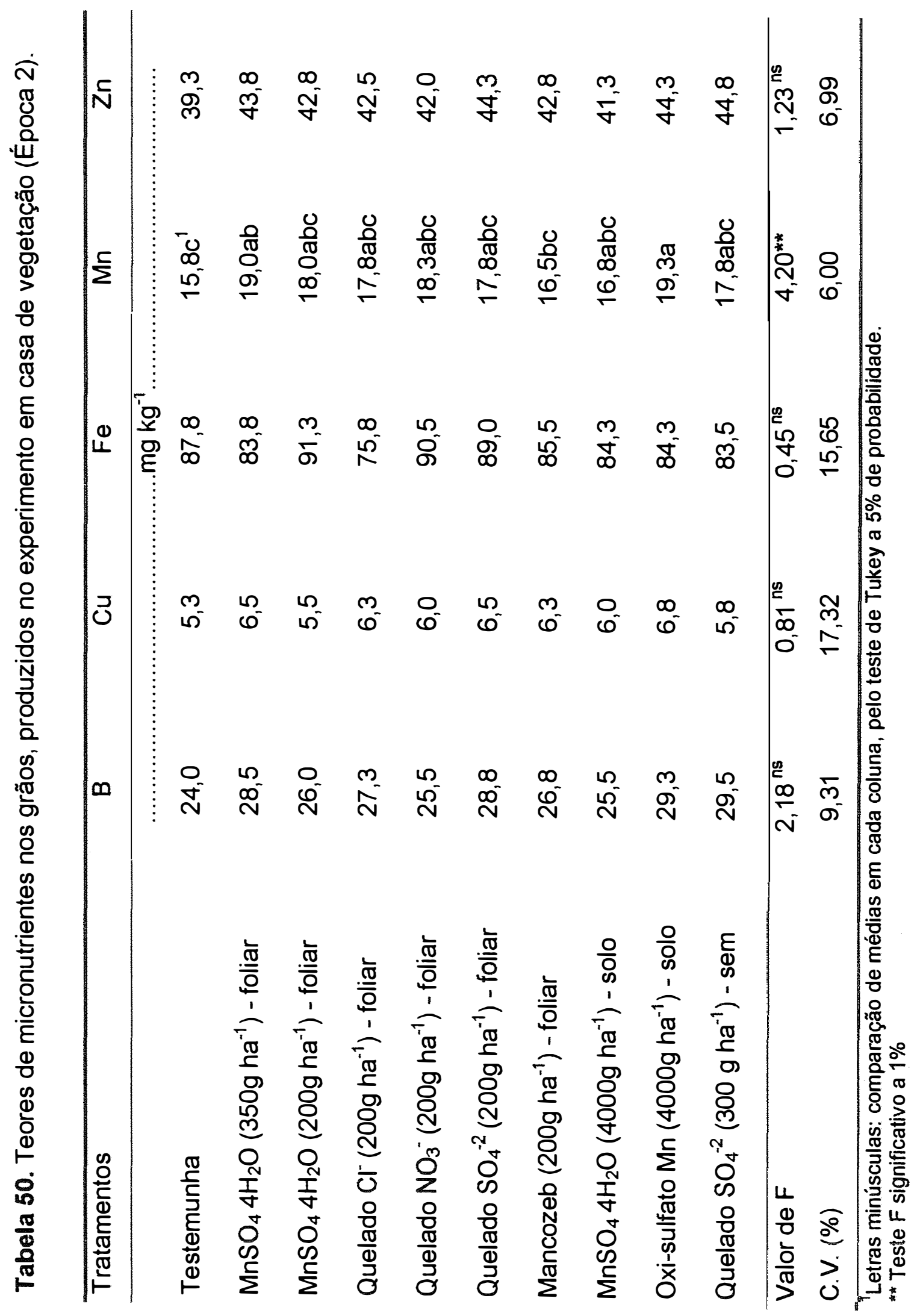


Os teores de Mn no grão, obtidos na época 2, embora aparentemente superiores à primeira época, apresentaram valores menores que os encontrados na literatura citada.

Os menores teores de $\mathrm{Mn}$ no grão foram verificados para a testemunha, sendo que a aplicação foliar de $\mathrm{MnSO}_{4} 4 \mathrm{H}_{2} \mathrm{O}\left(350 \mathrm{~g} \mathrm{ha}^{-1}\right)$ e a aplicação via solo de óxido de $\mathrm{Mn}$ (4000 $\mathrm{g} \mathrm{ha}^{-1}$ ) proporcionaram teores superiores à testemunha. Os demais tratamentos propiciaram teores intermediários de Mn no grão.

\subsubsection{Análises químicas de solo}

Os resultados referentes às análises químicas de solo estão apresentados na Tabela 51. Pode-se observar que, com exceção do manganês e do zinco, não foram verificadas diferenças entre os tratamentos estudados.

Os dados obtidos de análise de solo apresentaram valores considerados altos (Raij et al. 1997) para os macronutrientes $\mathrm{Ca}, \mathrm{Mg}, \mathrm{P}$ e S, sendo que os dois últimos mostraram níveis muito superiores ao solo original (Tabela 2), em decorrência do fornecimento de superfosfato simples na adubação básica dos vasos, por ocasião da semeadura (Tabela 4).

Os valores de $\mathrm{K}$, encontrados nas amostras de solo, apresentaram-se em níveis considerados baixos. Estes resultados devem-se ao acúmulo do nutriente na terra do fundo do vaso e ao tipo de amostragem realizada (conforme já discutido anteriormente). Além disso, depois do nitrogênio, o potássio é o nutriente mais extraído pela cultura da soja (Bataglia \& Mascarenhas, 1977) o que pode também ter contribuído para a redução no teor de $\mathrm{K}$ do solo. 


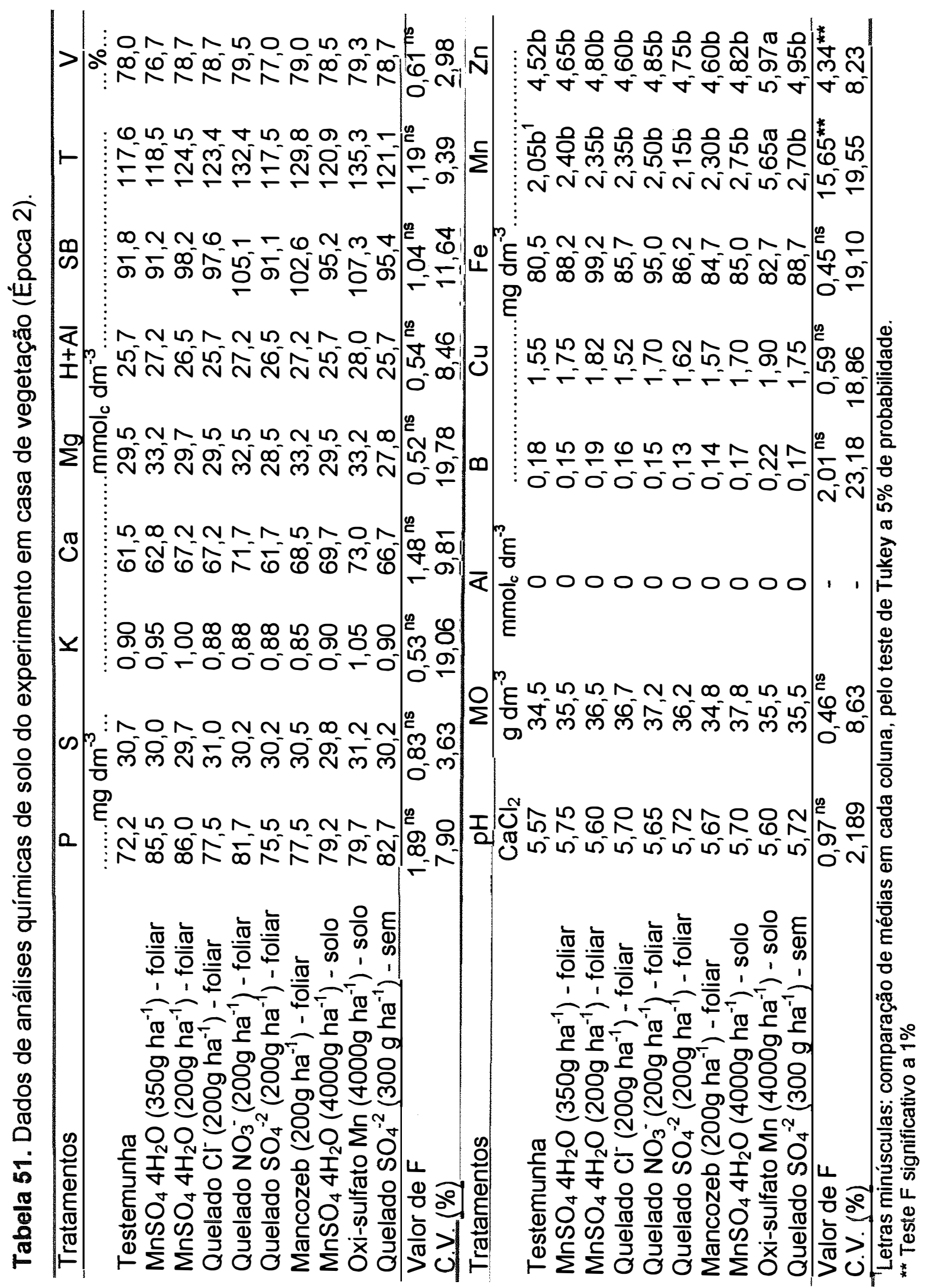


Assim como na época 1, foram observados valores considerados elevados de saturação por bases (V\%), pelos critérios de Sousa et al., (1989), Raij et al. (1997) e Embrapa (1998). Os valores de $\mathrm{pH}\left(\mathrm{CaCl}_{2}\right)$, por sua vez, revelaram condições de baixa acidez no solo, não havendo presença de Al trocável no solo.

Os teores de matéria orgânica mantiveram-se semelhantes à amostra inicial sendo considerados normais para um solo de textura argilosa, como o utilizado.

Os teores no solo de $\mathrm{K}$, Ca e $\mathrm{Mg}$, encontrados na época 2, foram aparentemente superiores aos da época 1 . O fato pode estar relacionado à menor extração ocorrida por esses nutrientes na época 2, em função da menor quantidade de matéria seca produzida.

Os teores de micronutrientes no solo, na época 2, foram semelhantes aos encontrados na época 1. Para os elementos $\mathrm{Cu}$, Fe e $\mathrm{Zn}$ foram observados niveis considerados altos (Raij et al., 1997).

Em relação ao $\mathrm{B}$, os teores encontrados podem ser considerados baixos pelos critérios já mencionados. Esta ocorrência, já observada na época 1 , pode estar relacionada à lixiviação de $B$, favorecida pelas condições de $\mathrm{pH}$ do solo (Dantas, 1991), tendo como consequência acúmulo no fundo do vaso, conforme foi verificado para o K. Não houve, no entanto, comprometimento do suprimento desse elemento às plantas durante o período experimental, uma vez que os teores de $\mathrm{B}$ encontrados na amostra inicial do solo não eram baixos (Tabela 3) e as amostragens de folhas revelaram níveis adequados de B. Além disso, o elemento foi fornecido no solo por ocasião da implantação do experimento (Tabela 4).

A aplicação via solo de oxi-sulfato de $\mathrm{Mn}$ (4000 $\mathrm{g} \mathrm{ha}^{-1}$ ) proporcionou a obtenção de teor de $\mathrm{Mn}$ no solo superior aos demais tratamentos. A presença de $\mathrm{Zn}$, verificada no referido produto (Tabela 6 ), refletiu num pequeno aumento no teor deste elemento no solo. 
Os teores de Mn encontraram-se em níveis considerados médios para o extrator utilizado (DTPA), pelos critérios de Raij et al. (1997), revelando, portanto, que a simples presença do $\mathrm{Mn}$ no solo não foi suficiente para suprir o elemento à planta.

Assim como na época 1, as condições encontradas no solo, tais como baixa acidez, elevada saturação por bases e altos teores de $\mathrm{Ca}, \mathrm{Mg}, \mathrm{P}, \mathrm{Cu}, \mathrm{Fe}$ e $\mathrm{Zn}$, comprometeram a disponibilidade do $\mathrm{Mn}$ às plantas, confirmando o observado por vários autores (Tanaka et al., 1992; Malavolta et al., 1991; Malavolta et al., 1997 e Marinho, 1988). Essas condições justificaram as melhores respostas obtidas pelo fornecimento do elemento via foliar, prática que aumentou o seu índice de aproveitamento ao impedir que o elemento ficasse sujeito às reações do solo, conforme também observou Volkweiss (1991).

\subsection{Experimento de campo}

\subsubsection{Teores foliares de nutrientes}

Os teores foliares de macronutrientes obtidos no experimento de campo, nos estádios fenológicos V4, R1, R4 e as médias dos três estágios, estão apresentados nas Tabelas 52, 53, 54 e 55, respectivamente. 


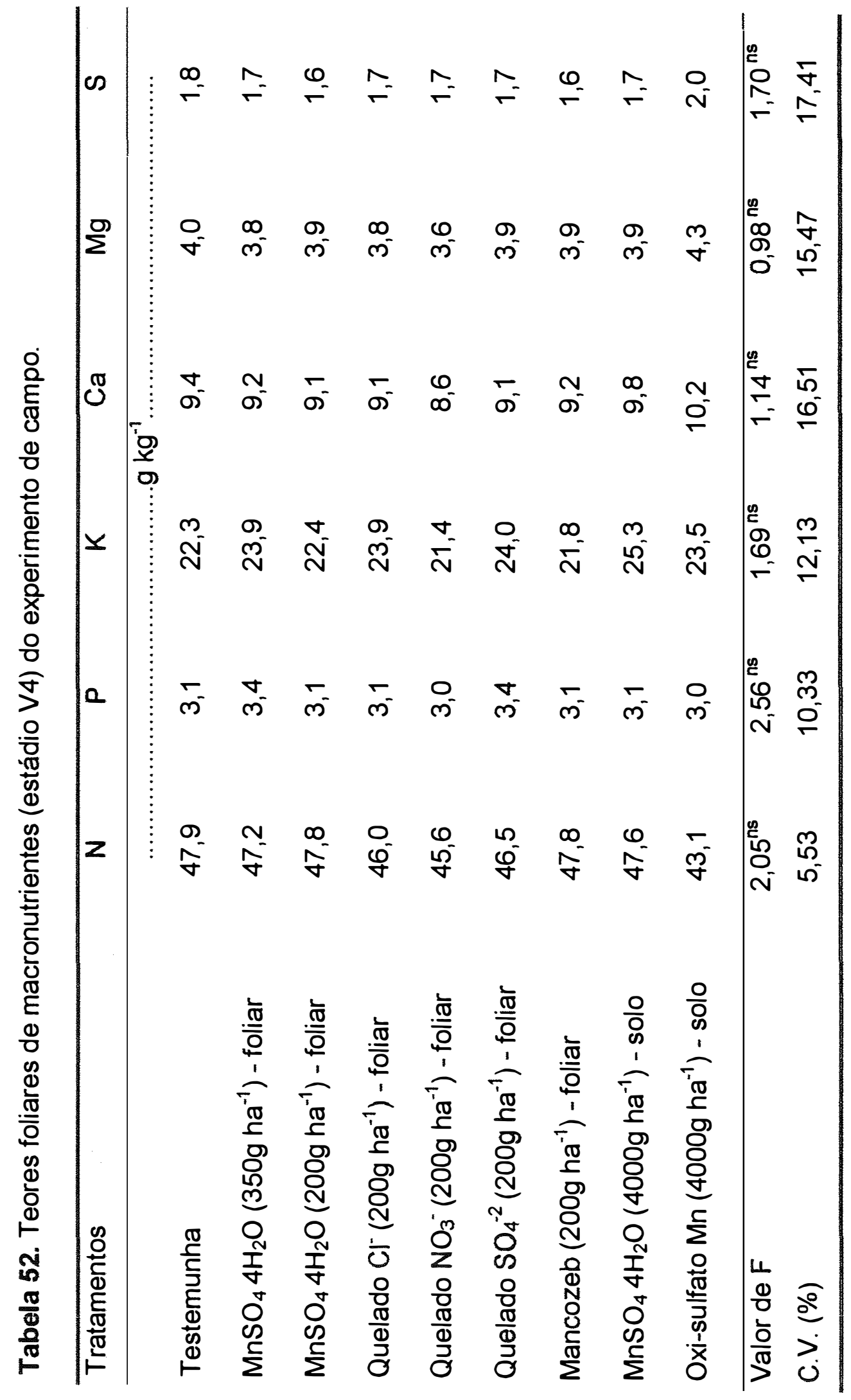




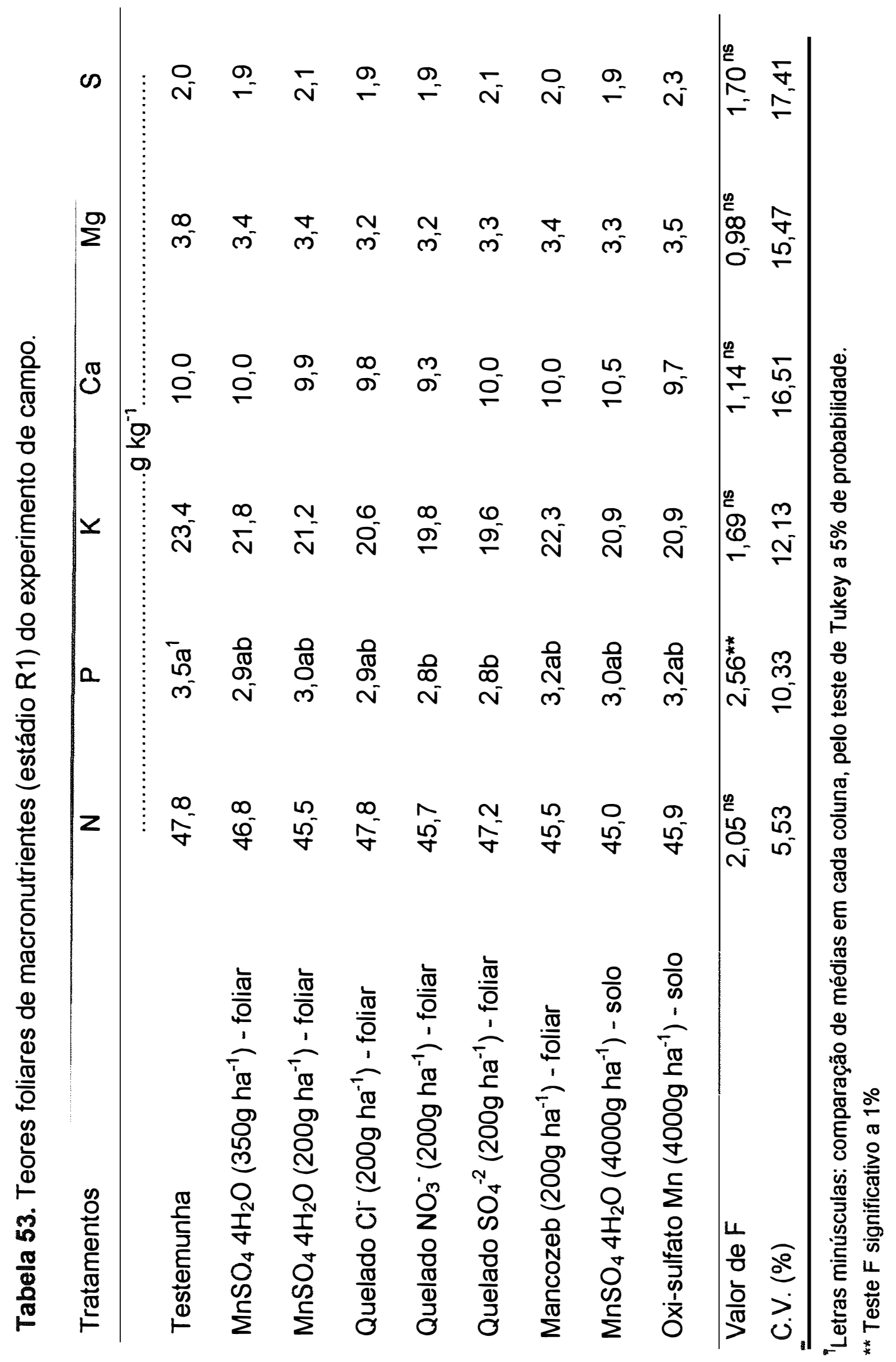




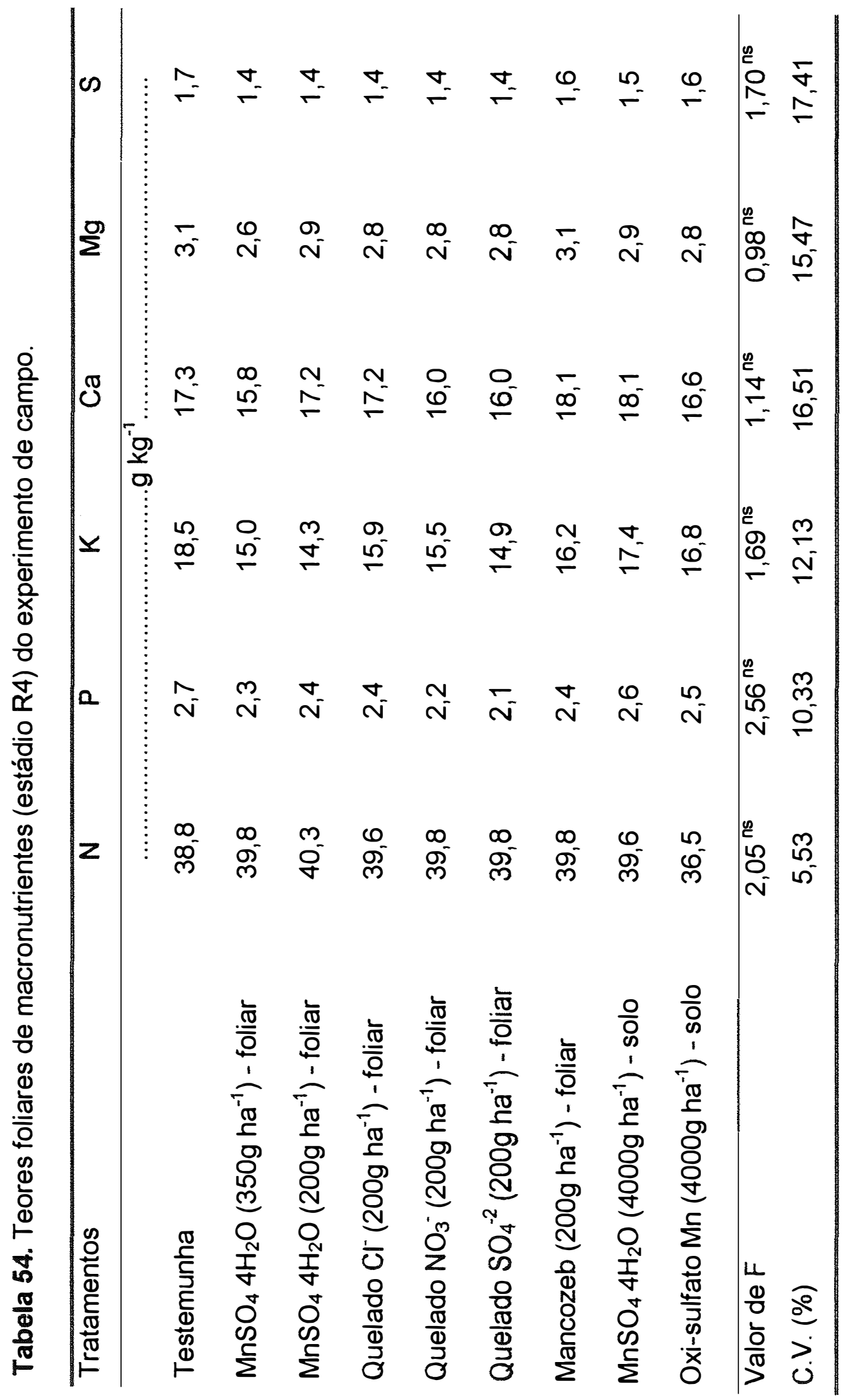




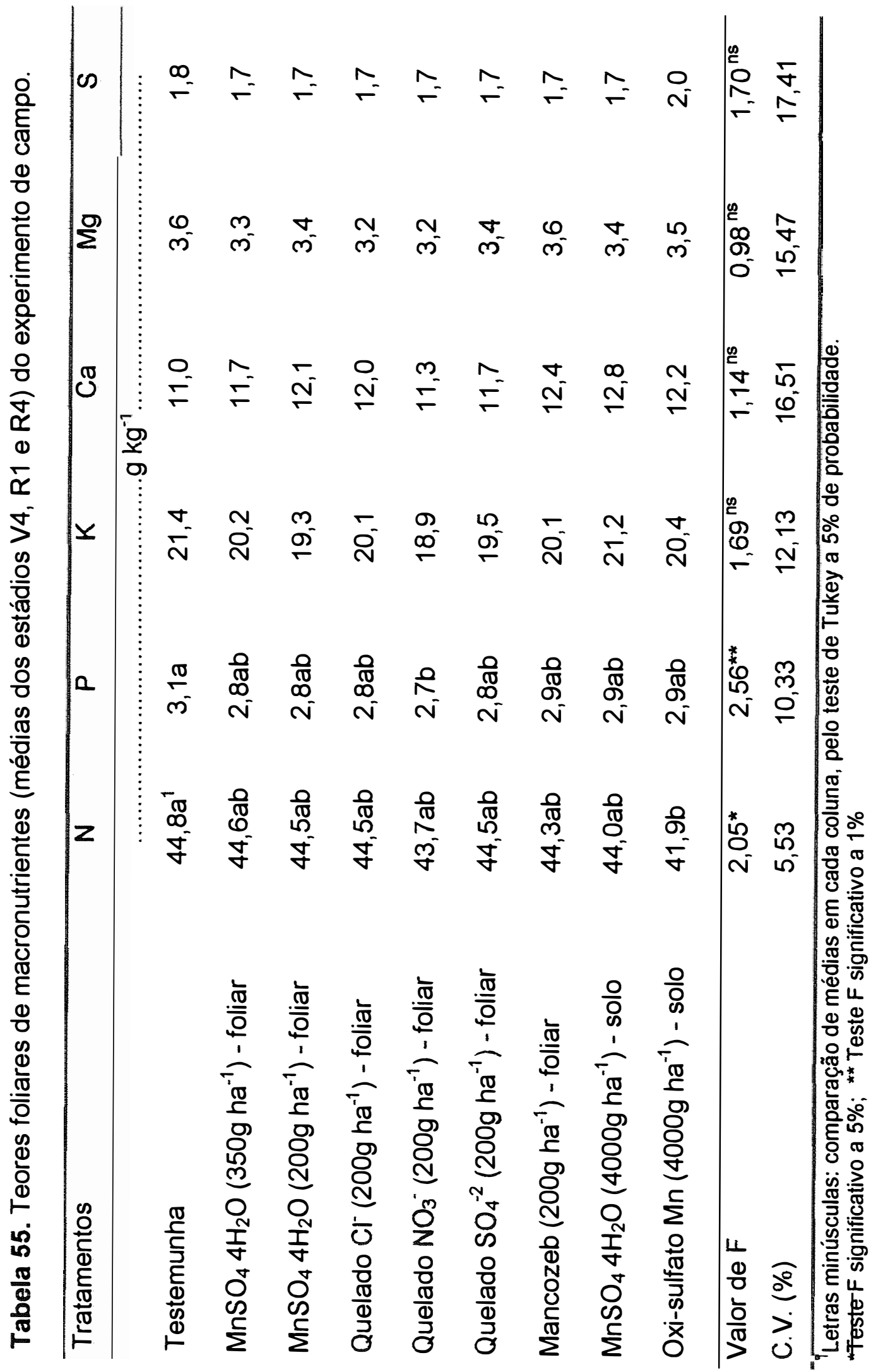


Considerando os critérios de suficiência adotados por Ambrosano et al. (1996), Malavolta et al. (1997) e Embrapa (1998), observou-se que os teores foliares de todos os macronutrientes, no estádio fenológico R1, encontravam-se dentro de níveis adequados, indicando um bom suprimento destes nutrientes às plantas no experimento de campo e, portanto, ausência de limitação em relação ao estado nutricional dos mesmos. Ao contrário dos experimentos de casa de vegetação, quando foram encontrados níveis de $\mathrm{N}$ e $\mathrm{P}$ considerados abaixo do crítico, esses resultados indicaram que as condições de campo foram mais favoráveis para o fornecimento apropriado destes nutrientes às plantas.

Foram encontradas diferenças, em função dos tratamentos, entre os níveis foliares de $\mathrm{P}$ (estádio R1) e entre $\mathrm{P}$ e $\mathrm{N}$ (média dos três estádios).

$O$ teor foliar de $P$ encontrado no estádio R1, na testemunha, foi superior daqueles encontrados nas plantas que receberam aplicação foliar de manganês, pelas fontes quelado $\mathrm{SO}_{4}{ }^{2-}$ e quelado $\mathrm{NO}_{3}^{-}\left(200 \mathrm{~g} \mathrm{ha}^{-1}\right)$, mostrando possível efeito destes tratamentos sobre o teor foliar de $\mathrm{P}$. Esses resultados levaram, na média dos três estádios fenológicos (Tabela 55) a um nível de $P$, da testemunha, também superior em relação às plantas tratadas com quelado $\mathrm{NO}_{3}^{-}$via foliar (200 $\left.\mathrm{g} \mathrm{ha}^{-1}\right)$.

O tratamento via solo com oxi-sulfato de manganês levou a teores foliares de $\mathrm{N}$ (média dos estádios V4, R1 e R4) menores que a testemunha. A análise dos resultados indicou que, para 0 tratamento oxi-sulfato de $\mathrm{Mn}, \mathrm{O}$ estádio V4 (Tabela 52) foi o que apresentou tendência a menor nível de nitrogênio foliar, o que efetivamente influenciou na média dos três estádios.

Franco \& Döbereiner (1971) relataram que a toxicidade de Mn em soja tem um efeito depressivo na nodulação da soja. Assim, a aplicação de oxisulfato de Mn junto à linha de plântulas, na fase inicial, pode ter favorecido a formação de uma região de alta concentração de $\mathrm{Mn}$ próxima às raízes, interferindo, temporariamente, no processo de nodulação e resultando na redução dos teores foliares de $\mathrm{N}$, principalmente nos estádios iniciais. No entanto, o mesmo efeito não foi observado na fonte $\mathrm{MnSO}_{4} 4 \mathrm{H}_{2} \mathrm{O}$. 
A comparação entre médias dos teores foliares de macronutrientes, nas três épocas de amostragem, está apresentada na Tabela 56.

Tabela 56. Comparação entre médias dos teores foliares de macronutrientes nos estádios V4, R1 e R4 do experimento de campo.

\begin{tabular}{|c|c|c|c|c|c|c|}
\hline Estádio & $\bar{N}$ & $\mathrm{P}$ & $\bar{K}$ & $\overline{\mathrm{Ca}}$ & $\overline{\mathrm{Mg}}$ & $S$ \\
\hline & \multicolumn{6}{|c|}{ ….............................. g kg } \\
\hline V4 & $46,6 a^{1}$ & $3,1 \mathrm{a}$ & $23,2 a$ & $9,1 b$ & $3,9 a$ & $1,7 \mathrm{~b}$ \\
\hline R1 & $46,4 a$ & $3,0 a$ & $21,2 b$ & $9,7 b$ & $3,4 b$ & $2,0 a$ \\
\hline R4 & $39,3 b$ & $2,4 b$ & $16,1 \mathrm{c}$ & $16,9 a$ & $2,8 c$ & $1,5 c$ \\
\hline $\begin{array}{l}\text { Valor de F } \\
\text { C.V. }(\%)\end{array}$ & $\begin{array}{c}128,40^{\star \star} \\
5,53\end{array}$ & $\begin{array}{l}84,62^{\star \star} \\
10,33\end{array}$ & $\begin{array}{c}101,36^{\star \star} \\
12,12\end{array}$ & $\begin{array}{c}220,97^{\star \star} \\
16,51\end{array}$ & $\begin{array}{l}44,92^{\star \star} \\
15,47\end{array}$ & $\begin{array}{l}32,16^{\star \star} \\
17,41\end{array}$ \\
\hline
\end{tabular}

Os resultados revelaram que os teores de $\mathrm{N}, \mathrm{P}$ e Ca não sofreram alterações entre os estádios V4 e R1; para K e Mg foi verificada redução e, para $\mathrm{S}$, aumento dos niveis foliares entre esses dois estádios. Com exceção do $\mathrm{Ca}$, que apresentou aumento nos teores, todos os macronutrientes apresentaram niveis foliares mais baixos em R4 que em R1.

A alta concentração de $\mathbf{N}$, encontrada nas folhas no estádio $R 1$, e a redução observada entre o estádio R1 e R4, relaciona-se ao fato de que o processo de fixaçảo biológica do $\mathrm{N}_{2}$ atinge seu máximo no florescimento pleno, declinando a partir do enchimento dos grãos, segundo estudos de Vargas et al. (1993).

A alta demanda por macronutrientes entre o início do florescimento e o enchimento dos grãos (Bataglia et al., 1977) justificou a redução nas concentrações foliares encontrada entre R1 e R4, conforme foi discutido no experimento de casa de vegetação, época 2. 
A baixa mobilidade de redistribuição do $\mathrm{Ca}$ pode explicar o acréscimo dos teores foliares deste elemento entre os estádios R1 e R4. Comportamento semelhante foi observado no experimento de casa de vegetação, época1.

Os teores de $\mathrm{N}, \mathrm{P}$ e $\mathrm{K}$ obtidos em R4 foram superiores aos encontrados por Hanway \& Weber (1971) e, com exceção do nitrogênio (que foi superior), os demais valores de macronutrientes encontrados foram semelhantes aos verificados por Malavolta et al. (1980).

Não foram encontradas diferenças entre os tratamentos no estádio V4 (Tabela 57) em relação aos níveis foliares de micronutrientes. Observou-se, no entanto, que os tratamentos provocaram alterações nos teores foliares de $\mathrm{B} e$ Mn, em R1 (Tabela 58), e Mn, em R4 (Tabela 59). A média dos três estádios (Tabela 60) revelou que os níveis foliares de $B$ e $M n$ sofreram influência dos tratamentos.

Os teores foliares de $\mathrm{B}, \mathrm{Cu}, \mathrm{Fe}$ e $\mathrm{Zn}$, observados em R1, enquadraram-se na faixa considerada adequada (Ambrosano et al., 1996; Malavolta et al., 1997 e Embrapa, 1998) sendo também semelhantes aos verificados por vários autores (Mascarenhas et al. 1980; Galrão, 1991; Tanaka et al., 1992b e Lazarini, 1995. Assim, pode deduzir-se que não houve limitação ao pleno desenvolvimento da planta em relação ao suprimento dos micronutrientes mencionados, nas condições em que se realizou o experimento.

As plantas tratadas com oxi-sulfato de $\mathrm{Mn}$ apresentaram maior teor foliar de B na amostragem feita em R1 (Tabela 58) e na média dos três estádios (Tabela 60).

Esses resultados, que também foram observados em R4 no experimento de casa de vegetação (época 2), acusaram o efeito do B presente no produto utilizado neste tratamento (Tabela 6), não havendo relação entre teores foliares de B e Mn. Nesse sentido, Reddy et al. (1987), trabalhando com diferentes genótipos de soja, também não encontraram efeito da aplicação de doses crescentes de manganês via solo $\left(0,10\right.$ e $\left.20 \mathrm{~kg} \mathrm{ha}^{-1}\right)$ sobre a concentração de $B$ em folhas coletadas no estádio R1. 


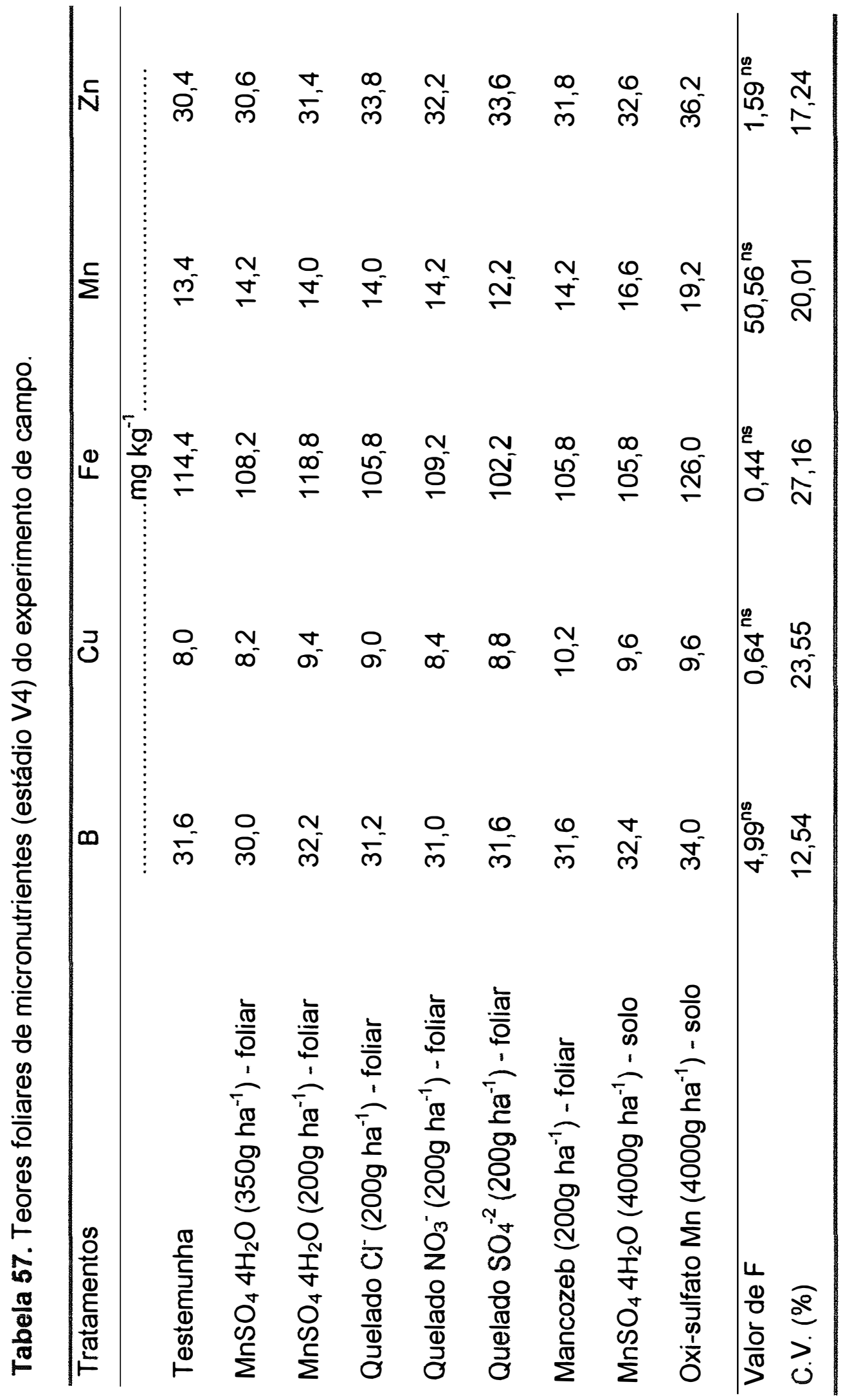




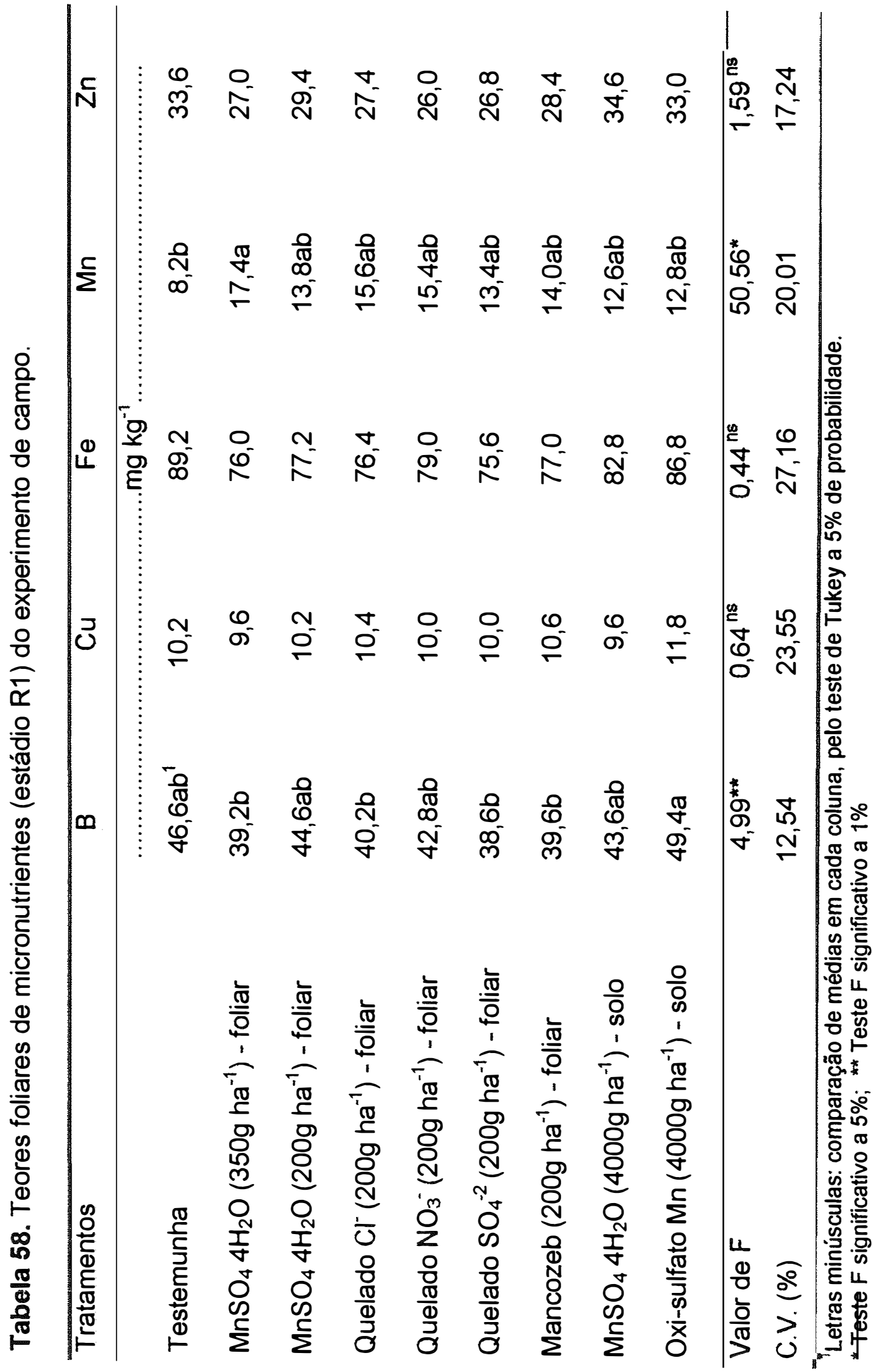




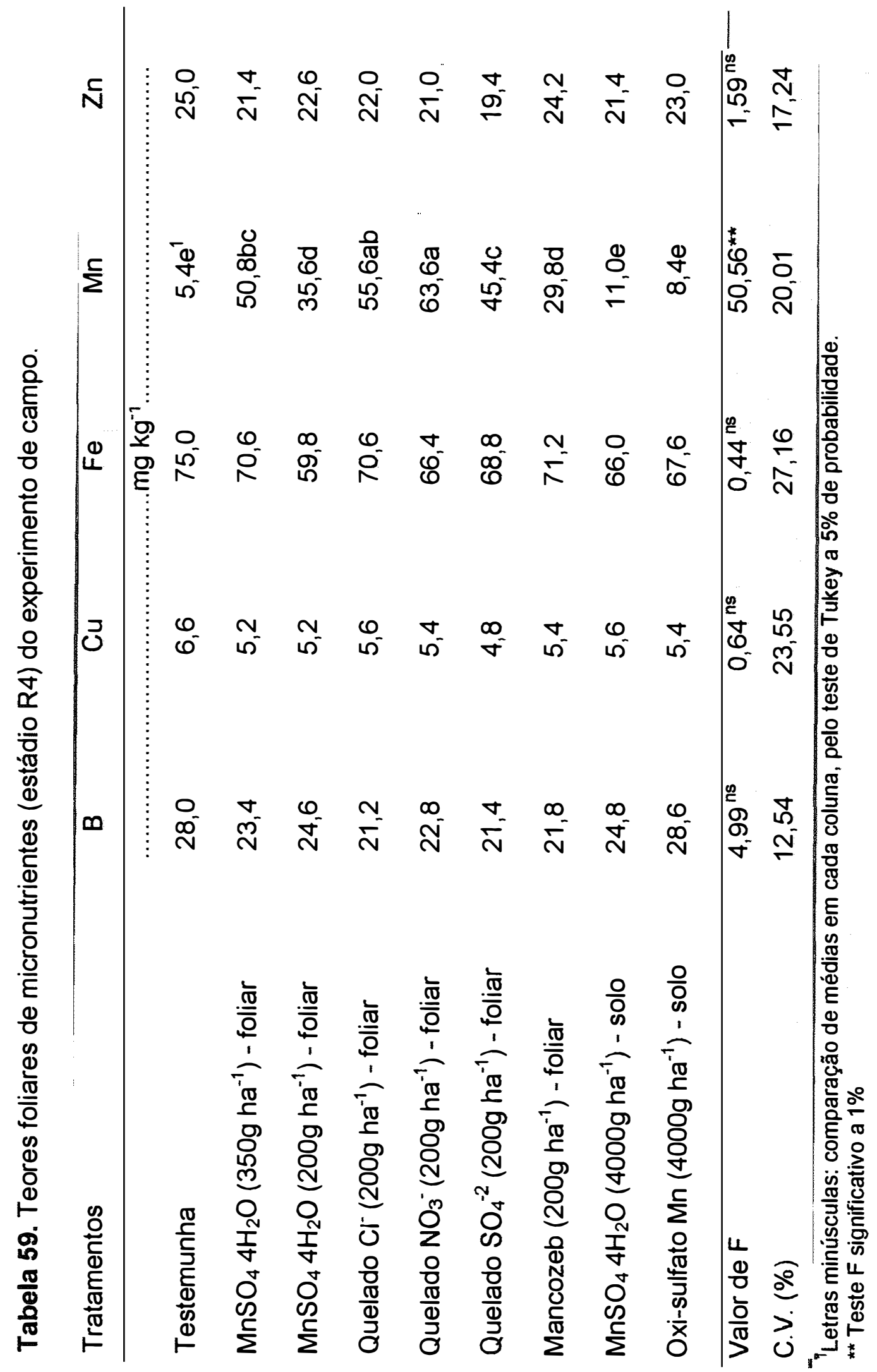




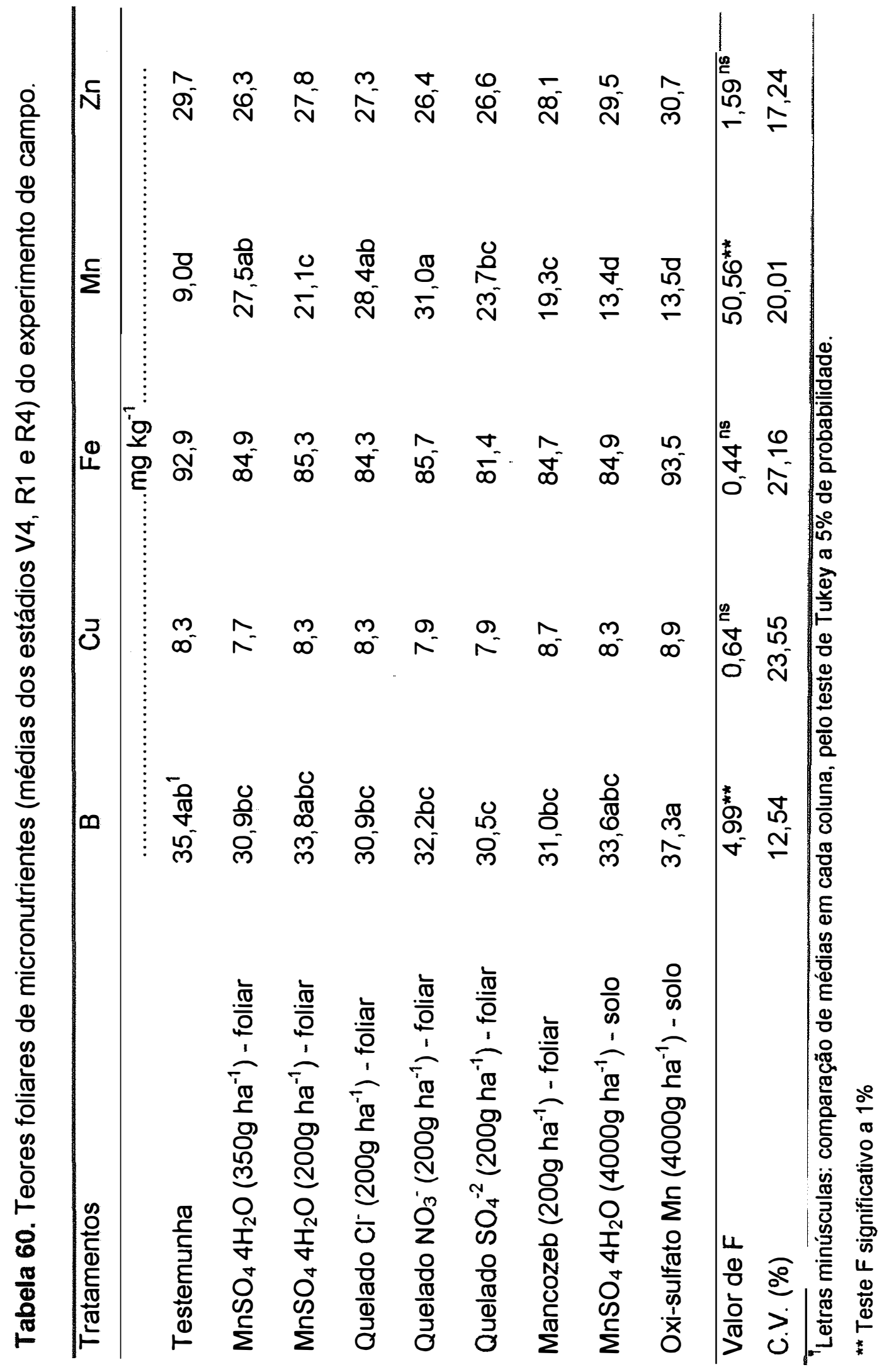


Os teores foliares de manganês, em R1 (Tabela 58), apresentaram-se abaixo dos níveis críticos. As plantas tratadas com $\mathrm{MnSO}_{4} 4 \mathrm{H}_{2} \mathrm{O}$ via foliar ( $350 \mathrm{~g}$ $\mathrm{ha}^{-1}$ ) mostraram valores de $\mathrm{Mn}$ superiores aos da testemunha; porém, juntamente com as tratadas com quelado $\mathrm{Cl}^{-}$e quelado $\mathrm{NO}_{3}^{-}$, apresentaram teores em patamares considerados baixos (Ambrosano et al., 1996; Malavolta et al., 1997 e Embrapa, 1998). Os demais tratamentos, resultaram em concentrações foliares muito baixas ou de deficiência.

As fortes condições de deficiência encontradas na área experimental, puderam ser observadas através dos severos sintomas visuais de deficiência de manganês apresentados pelas plantas da testemunha no estádio R1 (Figura 5). Além disso, a aplicação de Mn via solo, pelas duas fontes testadas, não foi suficiente para sequer assegurar teores foliares de Mn em R1 acima do nivel de deficiência, acusando a baixa eficiência desse método de fornecimento de manganês, em tais condições.

Por outro lado, o fornecimento de Mn via foliar, em V4, não foi suficiente para garantir o adequado nivel de manganês na planta, no estádio $\mathrm{R} 1$, indicando a necessidade de uma nova aplicação. $\mathrm{O}$ baixo desempenho apresentado pelo fornecimento do Mn via foliar, pela primeira aplicação em V4, pode estar relacionado com a área foliar relativamente reduzida neste estádio.

Em R4 (Tabela 59), as plantas da testemunha apresentaram, juntamente com as que receberam os tratamentos de $\mathrm{Mn}$ via solo, os menores teores de $\mathrm{Mn}$, os quais encontraram-se abaixo do nível crítico. Além disso, foram observados fortes sintomas visuais de deficiência de manganês nas plantas da testemunha e também, embora menos severos, nas plantas tratadas com Mn via solo. Os demais tratamentos promoveram aumento significativo nos teores do elemento nas folhas e não propiciaram sintomas visuais de deficiência. 


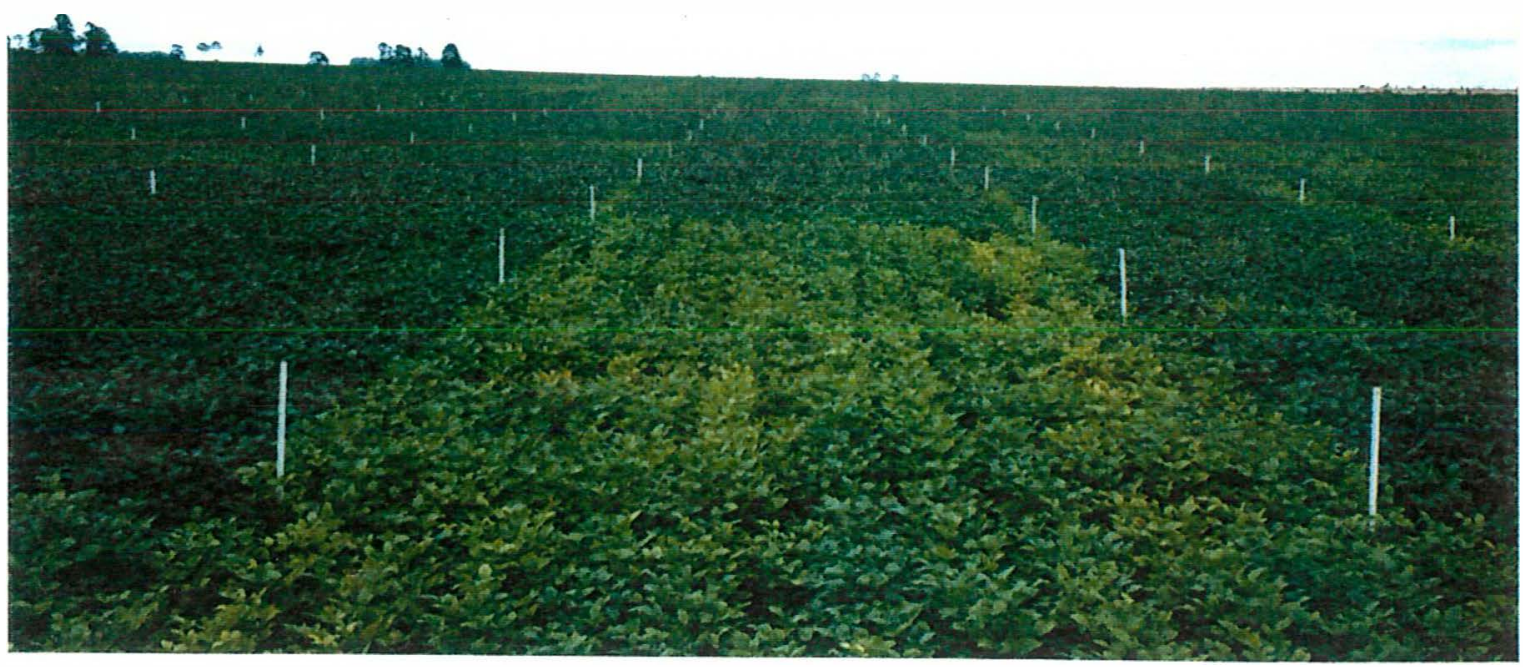

Figura 5. Sintomas visuais severos de deficiência de $\mathrm{Mn}\left(1^{\circ}\right.$ plano da foto), encontrados nas plantas da Testemunha, no estádio R1, no experimento de campo.

As plantas que receberam aplicação via foliar de quelados e $\mathrm{MnSO}_{4}$ $4 \mathrm{H}_{2} \mathrm{O}$ (350 $\mathrm{g} \mathrm{ha}^{-1}$ ) apresentaram os maiores teores foliares em R4, enquanto que os tratamentos com mancozeb e $\mathrm{MnSO}_{4} 4 \mathrm{H}_{2} \mathrm{O}$ (200 $\left.\mathrm{g} \mathrm{ha}^{-1}\right)$ proporcionaram valores menores.

Todos tratamentos via foliar, em R1, proporcionaram a elevação dos teores foliares de $\mathrm{Mn}$ em R4. Entre as fontes utilizadas, os quelados apresentaram-se, nesta fase, mais eficientes, uma vez que proporcionaram resultados semelhantes, com doses menores ao tratamento com $\mathrm{MnSO}_{4} 4 \mathrm{H}_{2} \mathrm{O}$ (350 $\left.\mathrm{g} \mathrm{ha}^{-1}\right)$, ou teores superiores, quando a dose foi a mesma $\left(\mathrm{MnSO}_{4} 4 \mathrm{H}_{2} \mathrm{O}\right.$, 
$200 \mathrm{~g} \mathrm{ha}^{-1}$ ). A aplicação de mancozeb resultou em teores foliares em R4 iguais à menor dose de $\mathrm{MnSO}_{4} 4 \mathrm{H}_{2} \mathrm{O}$.

Do mesmo modo que foi observado no experimento de casa de vegetação (épocas 1 e 2), o tratamento via solo não foi suficiente para manter os teores de Mn em R4 acima do encontrado na testemunha, confirmando a baixa eficácia deste tipo de fornecimento. Resultados semelhantes, foram verificados por Randall et al. (1975) e Volkweiss (1991).

A comparação de médias dos teores foliares de micronutrientes, nos estádios V4, R1 e R4 está apresentada na Tabela 61.

Tabela 61. Comparação entre médias dos teores foliares de micronutrientes nos estádios V4, R1 e R4 do experimento de campo.

\begin{tabular}{|c|c|c|c|c|c|}
\hline Estádio & $\bar{B}$ & $\overline{\mathrm{Cu}}$ & $\overline{\mathrm{Fe}}$ & $\mathrm{Mn}$ & $\overline{\mathrm{Zn}}$ \\
\hline & \multicolumn{5}{|c|}{ 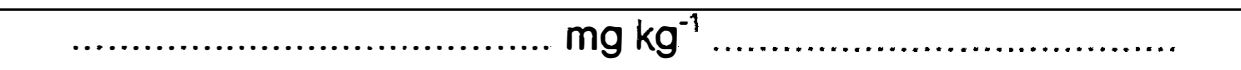 } \\
\hline V4 & $31,7 b^{1}$ & $9,0 b$ & $110,7 a$ & $14,7 \mathrm{~b}$ & $32,5 a$ \\
\hline R1 & $42,7 a$ & $10,3 a$ & $80,0 b$ & $13,7 b$ & $29,6 b$ \\
\hline R4 & $24,1 c$ & $5,5 c$ & $68,4 b$ & $33,9 a$ & $22,2 c$ \\
\hline $\begin{array}{l}\text { Valor de F } \\
\text { C.V. }(\%)\end{array}$ & $\begin{array}{c}233,55^{\star \star} \\
12,54\end{array}$ & $\begin{array}{l}73,92^{\star \star} \\
23,55\end{array}$ & $\begin{array}{l}38,97^{\star \star} \\
27,16\end{array}$ & $\begin{array}{c}340,29^{\star \star} \\
20,0\end{array}$ & $\begin{array}{l}53,85^{\text {t }} \\
17,24\end{array}$ \\
\hline
\end{tabular}

Com exceção do manganês, cuja média sofreu influência dos tratamentos, todos os micronutrientes apresentaram redução de teores do estádio V4 para R4.

Os maiores níveis de $\mathrm{B}$ foram observados no estádio R1. A menor precipitação, ocorrida na fase inicial da cultura, em comparação a R1 (Tabela 15), pode ter influenciado na disponibilidade do boro no solo, limitando, 
temporariamente, a sua absorção pela planta e, consequentemente, reduzindo a quantidade do elemento acumulada nas folhas amostradas no estádio V4, em relação a R1. O menor teor observado em R4 está ligado à maior exigência da planta, por este elemento, para formação de vagens e "enchimento" de grãos.

Os teores foliares de cobre apresentaram maiores niveis no estádio $\mathrm{R} 1$, o que pode indicar, em V4, eventual efeito das condições de baixa disponibilidade do elemento nas camadas superficiais do solo e, em R4, pela demanda natural para os grãos e consequente migração das folhas, conforme observado nos experimentos de casa de vegetação, época 2.

Em relação ao $\mathrm{Fe}$, ao contrário das condições de casa de vegetação, os maiores valores foram encontrados em V4, não havendo diferença entre os teores de R1 e R4, provavelmente devido à influência da diluição promovida pelo desenvolvimento vegetativo da planta.

Assim como verificado nas duas épocas dos experimentos de casa de vegetação, os teores foliares de zinco sofreram redução de V4 para R1 e de R1 para R4, indicando efeito da demanda por este elemento para o desenvolvimento vegetativo e reprodutivo da planta.

Os resultados encontrados em $\mathrm{R} 4$ para $\mathrm{B}, \mathrm{Fe}, \mathrm{Mn}$ e $\mathrm{Zn}$ foram menores aos obtidos por Malavolta et al. (1980), enquanto que os níveis de Cu mostraram-se semelhantes.

\subsubsection{Teor de clorofila nas folhas}

As leituras de teor de pigmento realizadas no experimento de campo, nos diferentes estádios fenológicos, estão apresentadas na Tabela 62. 
Tabela 62. Avaliação do teor de pigmento nas folhas, obtido pelo aparelho clorofilômetro, no experimento de campo.

\begin{tabular}{|c|c|c|c|c|}
\hline \multirow[t]{2}{*}{ Tratamentos } & \multicolumn{4}{|c|}{ Leitura - Teor de pigmento } \\
\hline & V4 & R1 & R4 & MÉDIA \\
\hline & \multicolumn{4}{|c|}{ SPAD. } \\
\hline Testemunha & $32,2 a A^{1}$ & $32,1 \mathrm{bA}$ & $32,4 \mathrm{cA}$ & $32,2 \mathrm{c}$ \\
\hline $\mathrm{MnSO}_{4} 4 \mathrm{H}_{2} \mathrm{O}\left(350 \mathrm{~g} \mathrm{ha}^{-1}\right)$ - foliar & $31,9 a C$ & $38,7 a B$ & $49,6 a A$ & $40,1 a$ \\
\hline $\mathrm{MnSO}_{4} 4 \mathrm{H}_{2} \mathrm{O}\left(200 \mathrm{~g} \mathrm{ha}^{-1}\right)$ - foliar & $32,1 \mathrm{aC}$ & $38,5 a B$ & $48,3 a A$ & $39,7 a$ \\
\hline Quelado $\mathrm{Cl}^{-}\left(200 \mathrm{~g} \mathrm{ha}^{-1}\right)$ - foliar & $33,0 \mathrm{aC}$ & $38,8 a B$ & $49,0 \mathrm{aA}$ & $40,2 a$ \\
\hline Quelado $\mathrm{NO}_{3}^{-}\left(200 \mathrm{~g} \mathrm{ha}^{-1}\right)$ - foliar & $32,9 a C$ & $39,1 \mathrm{aB}$ & $48,9 a A$ & $40,3 a$ \\
\hline Quelado $\mathrm{SO}_{4}^{-2}\left(200 \mathrm{~g} \mathrm{ha}^{-1}\right)$ - foliar & $32,0 \mathrm{aC}$ & $38,7 a B$ & $48,3 a A$ & $39,7 a$ \\
\hline Mancozeb (200 g ha $\left.{ }^{-1}\right)$ - foliar & $32,3 a C$ & $36,3 a B$ & $47,0 a A$ & $38,5 a b$ \\
\hline $\mathrm{MnSO}_{4} 4 \mathrm{H}_{2} \mathrm{O}\left(4000 \mathrm{~g} \mathrm{ha}^{-1}\right)$ - solo & $34,6 a B$ & $37,7 a A$ & $38,9 \mathrm{bA}$ & $37,1 b$ \\
\hline Oxi-sulfato Mn (4000g ha-1) - solo & $34,9 a B$ & $36,3 a B$ & $38,1 \mathrm{bA}$ & $36,5 b$ \\
\hline MEEDIA & $32,9 \mathrm{C}$ & $37,4 \mathrm{~B}$ & $44,5 \mathrm{~A}$ & \\
\hline $\begin{array}{l}\text { Valor de F } \\
\text { C.V. }(\%)\end{array}$ & $\begin{array}{c}25,15^{\star \star *} \\
5,35 \\
\end{array}$ & & & \\
\hline
\end{tabular}

Letras minúsculas, comparação em cada coluna e letras maiúsculas comparação em cada linha, pelo teste de Tukey a $5 \%$ de probabilidade.

** Teste F significativo a $1 \%$

Com exceção da testemunha, cujas plantas mantiveram leituras semelhantes nos três estádios, todos os tratamentos resultaram em diferentes leituras entre as amostragens. As plantas que receberam aplicação de manganês, via foliar, apresentaram leituras crescentes de pigmento entre os três estádios, já as plantas tratadas com $\mathrm{MnSO}_{4} 4 \mathrm{H}_{2} \mathrm{O}$ via solo, tiveram aumento apenas de V4 para R1, mantendo valores iguais de R1 para R4, enquanto que a aplicação de oxi-sulfato de $\mathrm{Mn}$ via solo, resultou em aumento apenas de R1 para R4.

Entre os tratamentos, constatou-se que não houve diferença de leitura dentro do estádio V4. No estádio $\mathrm{R} 1$, as plantas que não receberam 
suplementação de Mn (testemunha), apresentaram o menor valor de leitura de pigmento. As maiores leituras, no estádio R4, foram observadas nas plantas que receberam tratamento via foliar, seguidas das plantas tratadas via solo, sendo que as menores leituras foram verificadas na testemunha.

Assim, as médias das leituras dos três estádios, revelaram que os maiores valores foram obtidos nas plantas tratadas com $\mathrm{Mn}$ via foliar. Num segundo grupo pode-se colocar as plantas tratadas via solo e por último as testemunhas.

Esses resultados revelaram que tanto o estado de deficiência da planta quanto a correção da clorose promovida pelo fornecimento de manganês, puderam ser detectados pelo aparelho clorofilômetro.

Ao contrário dos experimentos em casa de vegetação, foi possível estabelecer correlações entre as leituras de pigmento e os teores foliares de $\mathrm{Mn}$ nos diferentes estádios (Figura 6), as quais indicaram grande potencial do uso do clorofilômetro como opção para diagnose rápida do estado nutricional das plantas de soja para o manganês.

Os teores de clorofila calculados a partir da equação de Barnes et al. (1992), estão apresentados na Tabela 63.

Os resultados dos teores de clorofila apresentaram as mesmas tendências observadas nas leituras de pigmento, ratificando, sob este aspecto, que o fornecimento de $\mathrm{Mn}$ via foliar foi mais efetivo que a aplicação via solo. 


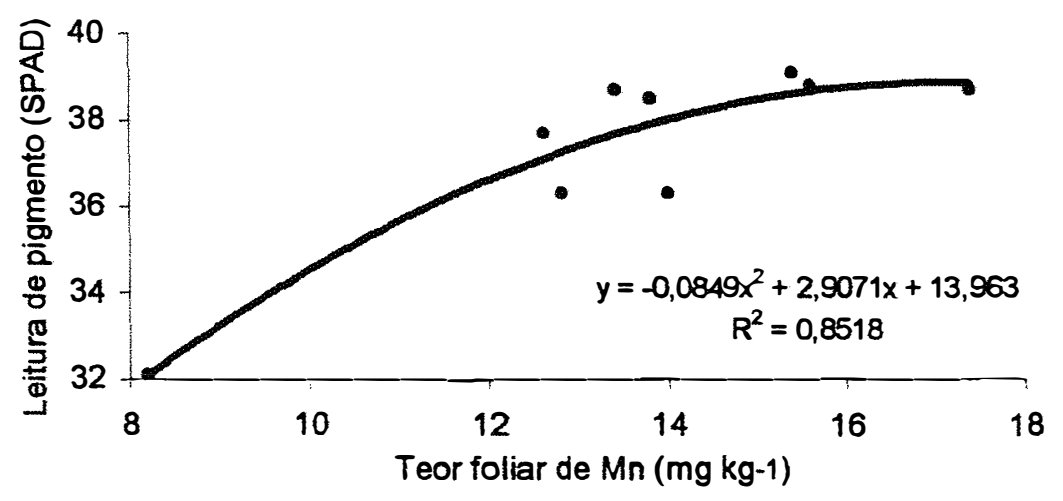

A

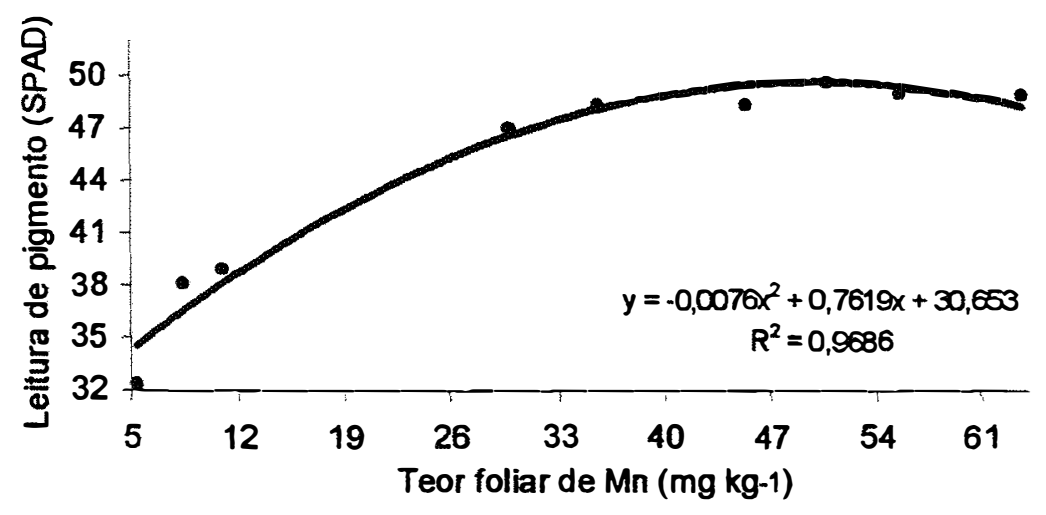

B

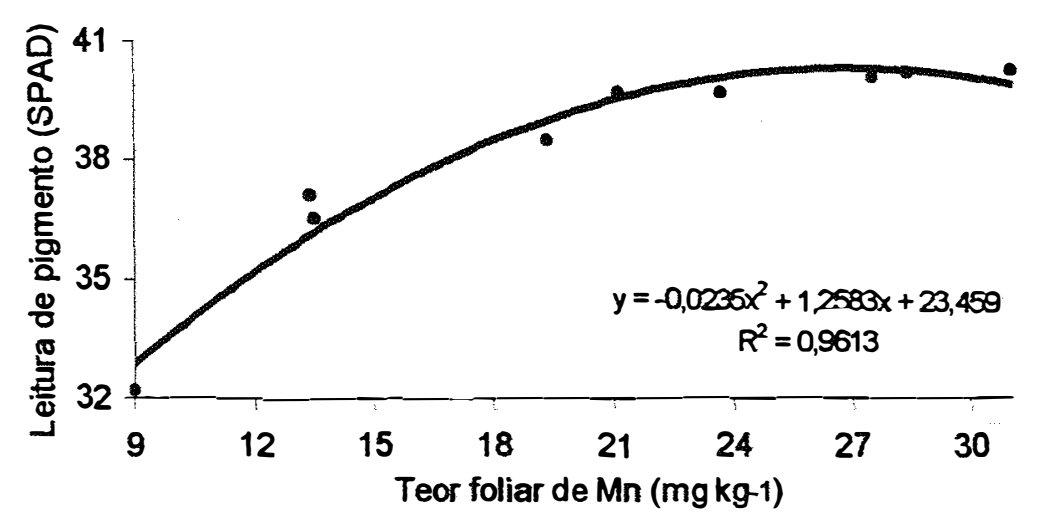

C

Figura 6. Relação entre teor foliar de $\mathrm{Mn}$ e leitura de pigmento na folha no experimento de campo: estádio R1 (A), estádio R4 (B) e média dos estádios V4, R1 e R4 (C). 
Tabela 63. Concentração de clorofila nas folhas, no experimento de campo.

\begin{tabular}{|c|c|c|c|c|}
\hline \multirow[t]{2}{*}{ Tratamentos } & \multicolumn{4}{|c|}{ Concentração de clorofila } \\
\hline & V4 & R1 & R4 & MEDIA \\
\hline & \multicolumn{4}{|c|}{ 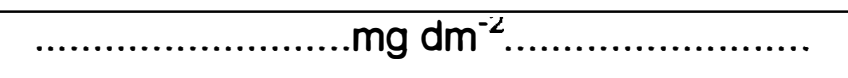 } \\
\hline Testemunha & $3,06 \mathrm{aA}^{1}$ & $3,05 \mathrm{bA}$ & $3,08 \mathrm{cA}$ & $3,06 c$ \\
\hline $\mathrm{MnSO}_{4} 4 \mathrm{H}_{2} \mathrm{O}\left(350 \mathrm{~g} \mathrm{ha}^{-1}\right)$ - foliar & $3,03 a C$ & $3,71 \mathrm{aB}$ & $4,79 a A$ & $3,84 a$ \\
\hline $\mathrm{MnSO}_{4} 4 \mathrm{H}_{2} \mathrm{O}\left(200 \mathrm{~g} \mathrm{ha}^{-1}\right)$ - foliar & $3,05 \mathrm{aC}$ & $3,69 a \mathrm{~B}$ & $4,66 a A$ & $3,80 a$ \\
\hline Quelado $\mathrm{Cl}^{-}\left(200 \mathrm{~g} \mathrm{ha}^{-1}\right)$ - foliar & $3,13 a C$ & $3,71 \mathrm{aB}$ & $4,72 \mathrm{aA}$ & $3,85 a$ \\
\hline Quelado $\mathrm{NO}_{3}^{-}\left(200 \mathrm{~g} \mathrm{ha}^{-1}\right)$ - foliar & $3,13 a C$ & $3,75 a \mathrm{aB}$ & $4,71 \mathrm{aA}$ & $3,86 a$ \\
\hline Quelado $\mathrm{SO}_{4}^{-2}\left(200 \mathrm{~g} \mathrm{ha}^{-1}\right)$ - foliar & $3,04 a C$ & $3,70 \mathrm{aB}$ & $4,66 \mathrm{aA}$ & $3,80 a$ \\
\hline Mancozeb (200 g ha-1) - foliar & $3,07 \mathrm{aC}$ & $3,46 a \mathrm{~B}$ & $4,53 a A$ & $3,69 a b$ \\
\hline $\mathrm{MnSO}_{4} 4 \mathrm{H}_{2} \mathrm{O}\left(4000 \mathrm{~g} \mathrm{ha}^{-1}\right)$ - solo & $3,29 a B$ & $3,60 \mathrm{aA}$ & $3,72 \mathrm{bA}$ & $3,54 b$ \\
\hline Oxi-sulfato Mn (4000g ha-1) - solo & $3,33 \mathrm{aB}$ & $3,47 \mathrm{aAB}$ & $3,64 \mathrm{bA}$ & $3,48 b$ \\
\hline MÉDIA & $3,12 \mathrm{C}$ & $3,58 \mathrm{~B}$ & $4,28 \mathrm{~A}$ & \\
\hline $\begin{array}{l}\text { Valor de F } \\
\text { C.V. }(\%)\end{array}$ & $\begin{array}{c}15,09^{\star \star} \\
5,41\end{array}$ & & & \\
\hline
\end{tabular}

\subsubsection{Altura final da planta}

Foram encontradas diferenças entre os tratamentos para o parâmetro altura final de plantas, conforme apresentado na Tabela 64. Os resultados revelaram que as plantas da testemunha apresentaram redução na altura final, em relação às plantas tratadas com $\mathrm{Mn}$ via foliar. Valores intermediários foram encontrados naquelas que receberam o elemento via solo. 
Tabela 64. Dados de altura final da planta do experimento de campo.

\begin{tabular}{|c|c|}
\hline Tratamentos & Altura final da planta \\
\hline & 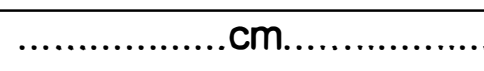 \\
\hline Testemunha & $80,72 b^{1}$ \\
\hline $\mathrm{MnSO}_{4} 4 \mathrm{H}_{2} \mathrm{O}\left(350 \mathrm{~g} \mathrm{ha}^{-1}\right)$ - foliar & $88,86 a$ \\
\hline $\mathrm{MnSO}_{4} 4 \mathrm{H}_{2} \mathrm{O}\left(200 \mathrm{~g} \mathrm{ha}^{-1}\right)$ - foliar & $88,28 a$ \\
\hline Quelado $\mathrm{Cl}^{-}\left(200 \mathrm{~g} \mathrm{ha}^{-1}\right)$ - foliar & $89,76 a$ \\
\hline Quelado $\mathrm{NO}_{3}^{-}\left(200 \mathrm{~g} \mathrm{ha}^{-1}\right)$ - foliar & $89,58 a$ \\
\hline Quelado $\mathrm{SO}_{4}^{-2}\left(200 \mathrm{~g} \mathrm{ha}^{-1}\right)$ - foliar & $88,60 a$ \\
\hline Mancozeb (200 g ha ${ }^{-1}$ ) - foliar & $86,16 a$ \\
\hline $\mathrm{MnSO}_{4} 4 \mathrm{H}_{2} \mathrm{O}\left(4000 \mathrm{~g} \mathrm{ha}^{-1}\right)$ - solo & $85,48 a b$ \\
\hline Oxi-sulfato Mn (4000g ha-1) - solo & $85,00 a b$ \\
\hline Valor de F & $8,00^{\star \star}$ \\
\hline C.V. (\%) & 2,66 \\
\hline
\end{tabular}

Tetras minúsculas: comparação em cada coluna, pelo teste de Tukey a $5 \%$ de probabilidade.

- Teste F significativo a $1 \%$

A redução na altura final das plantas pode indicar produção de matéria seca igualmente menor. Abreu et al. (1994) concluíram que o cultivar Garimpo mostrou-se, dentre outros 12 estudados, o mais sensivel à deficiência de manganês pelo parâmetro produção de matéria seca, indicando, consequentemente, que a deficiência desse elemento pode também afetar a altura final da planta.

\subsubsection{Produção de grãos}

A produção de grãos e a produção relativa estão apresentados na Tabela 65. 
Tabela 65. Dados de produção de grãos e produção relativa do experimento de campo.

\begin{tabular}{|c|c|c|}
\hline Tratamentos & Produção de grãos & Produção relativa \\
\hline & $\mathrm{kg} \mathrm{ha}^{-1} \ldots . .$. & $\ldots \ldots . . . . .$. \\
\hline Testemunha & $2247 b^{1}$ & 100 \\
\hline $\mathrm{MnSO}_{4} 4 \mathrm{H}_{2} \mathrm{O}\left(350 \mathrm{~g} \mathrm{ha}^{-1}\right)$ - foliar & $2821 a$ & 125 \\
\hline $\mathrm{MnSO}_{4} 4 \mathrm{H}_{2} \mathrm{O}\left(200 \mathrm{~g} \mathrm{ha}^{-1}\right)$ - foliar & $2769 a$ & 123 \\
\hline Quelado $\mathrm{Cl}^{-}\left(200 \mathrm{~g} \mathrm{ha}^{-1}\right)$ - foliar & $2782 a$ & 124 \\
\hline Quelado $\mathrm{NO}_{3}^{-}\left(200 \mathrm{~g} \mathrm{ha}^{-1}\right)$ - foliar & $2788 a$ & 124 \\
\hline Quelado $\mathrm{SO}_{4}^{-2}\left(200 \mathrm{~g} \mathrm{ha}^{-1}\right)$ - foliar & $2827 a$ & 126 \\
\hline Mancozeb (200 g ha ${ }^{-1}$ ) - foliar & $2659 a b$ & 118 \\
\hline $\mathrm{MnSO}_{4} 4 \mathrm{H}_{2} \mathrm{O}\left(4000 \mathrm{~g} \mathrm{ha}^{-1}\right)$ - solo & $2499 a b$ & 111 \\
\hline Oxi-sulfato $\mathrm{Mn}\left(4000 \mathrm{~g} \mathrm{ha}^{-1}\right)$ - solo & $2526 a b$ & 112 \\
\hline Valor de F & $4,73^{\star \star}$ & \\
\hline C.V. (\%) & 6,83 & \\
\hline
\end{tabular}

Letras minúsculas: comparação em cada coluna, pelo teste de Tukey a $5 \%$ de probabilidade.

** Teste F significativo a $1 \%$

Os resultados mostraram que as plantas que receberam tratamentos com sulfato de manganês e quelados via foliar apresentaram produções maiores que a testemunha, enquanto que os tratamentos via solo e a aplicação foliar de mancozeb proporcionaram produções intermediárias.

As plantas tratadas com manganês via solo apresentaram tendência de produção cerca de $10 \%$ superior à testemunha, resultado muito semelhante ao encontrado por Mann et al. (1999a).

O aumento de produção de grãos, encontrado pela aplicação foliar de manganês (ao redor de $25 \%$ a mais que a testemunha), revelaram a importância deste método de fornecimento em condições de deficiência severa do elemento. $O$ aumento de produção, em decorrência da aplicação foliar de manganês, foi semelhante ao observado no experimento de casa de vegetação 
(época 2) e confirma os resultados encontrados por Randall et al. (1975), Zito et al. (1999) e Mann et al. (1999b).

A superioridade observada pela aplicação de manganês via foliar, em relação à aplicação ao solo, contrariando os resultados de Mann et al. (1999b), deve-se ao alto índice de utilização pelas plantas, uma vez que fora do contato com o solo o nutriente não se sujeitou às reações de insolubilização ou perdas por diversas causas, permitindo a aplicação de doses menores, conforme observaram Alley et al. (1978) e Volkweiss (1991).

Considerando que o estado nutricional da planta em relação ao manganês interferiu na produtividade, foi possivel estabelecer correlações entre teor foliar de manganês e produção de grãos (Figura 7). Nesse sentido, também foram encontradas correlações entre leitura de pigmento nas folhas e produção de grãos (Figura 8).

O teor foliar de manganês médio, encontrado nos três estádios, foi o que melhor se correlacionou com a produção de grãos, ficando confirmada esta relação também pela leitura de pigmento média dos três estádios. 


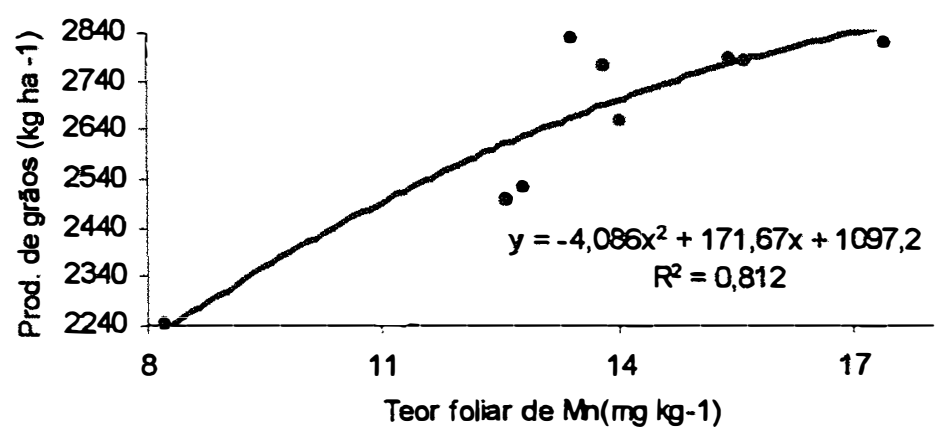

\section{A}

B

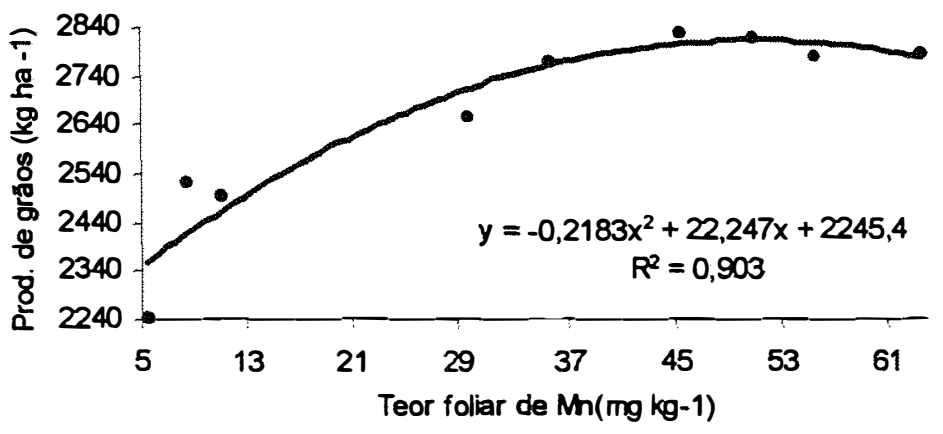

C

Figura 7. Relação entre teor foliar de $\mathrm{Mn}$ e produção de grãos $\left(\mathrm{kg} \mathrm{ha}^{-1}\right)$ no experimento de campo: estádio R1 (A), estádio R4 (B) e média dos estádios V4, R1 e R4 (C). 


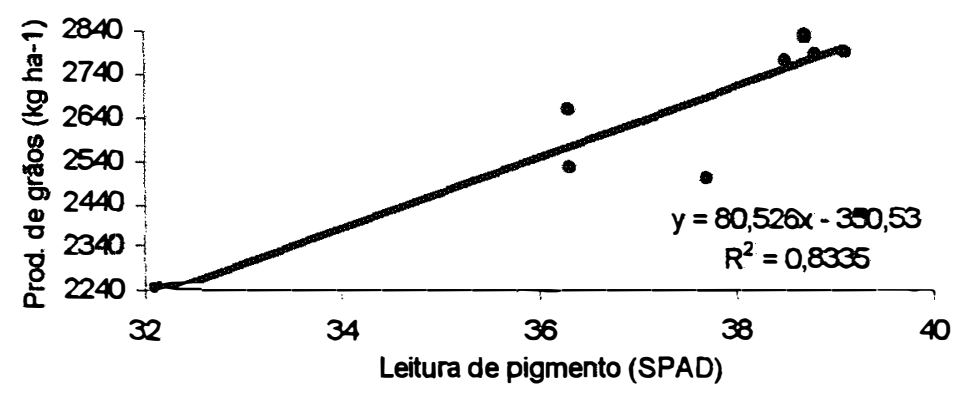

A

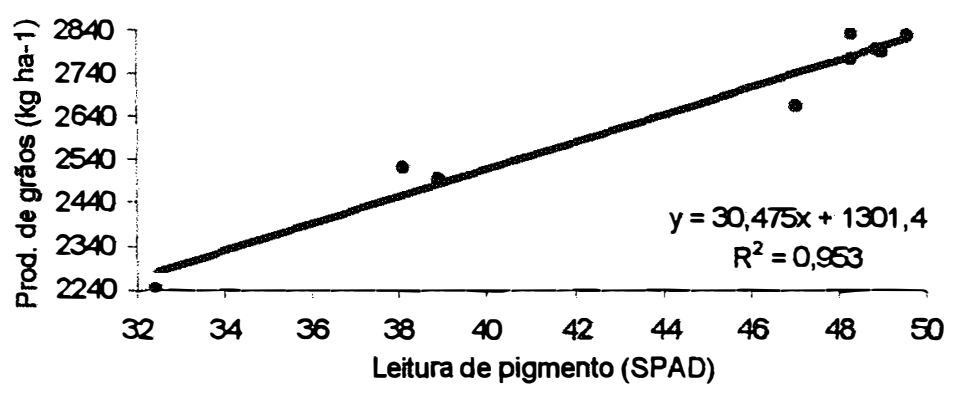

B

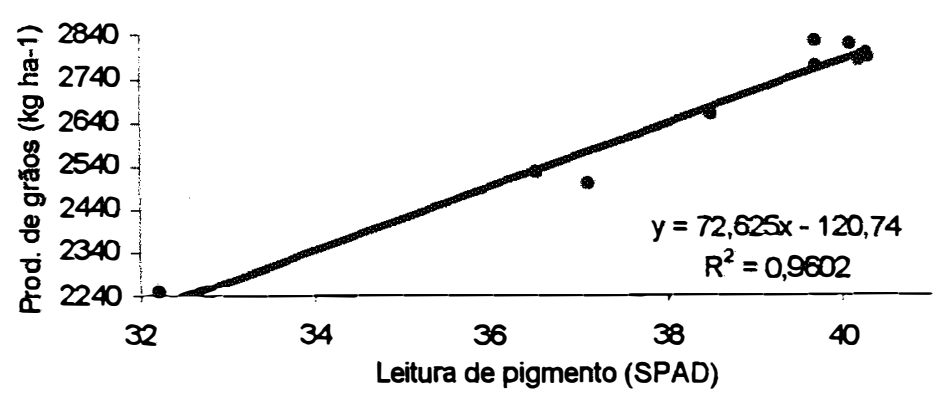

C

Figura 8. Relação entre leitura de clorofila e produção de grãos $\left(\mathrm{kg} \mathrm{ha}^{-1}\right)$ no experimento de campo: estádio R1 (A), estádio R4 (B) e média dos estádios V4, R1 e R4 (C). 


\subsubsection{Teores de nutrientes no grão}

Os teores de macro e micronutrientes encontrados nos grãos, cujos resultados encontram-se nas Tabelas 66 e 67, respectivamente, revelaram efeito dos tratamentos sobre as concentrações de N, Mn e Zn .

Os niveis de macronutrientes verificados nos grãos apresentaram valores semelhantes às médias encontradas por Mascarenhas et al. (1980), Oliveira et al. (1991), Lazarini (1995) e Embrapa (1998). Observou-se que os grãos produzidos, em comparação aos teores encontrados nas sementes utilizadas (Tabela 7), apresentaram níveis superiores para cálcio e semelhantes para os demais macronutrientes.

Em relação aos micronutrientes, alguns autores encontraram teores superiores: Mascarenhas et al. (1980) para Cu, Zn e Mn; Oliveira et al. (1991) para $\mathrm{Cu}, \mathrm{Fe}$ e Mn e Lazarini (1995) para $\mathrm{Zn}$ e Mn. No caso das médias verificadas por Embrapa (1998), com exceção do $\mathrm{Mn}$, os valores dos demais micronutrientes foram semelhantes. Quando comparados às concentrações encontradas nas sementes utilizadas (Tabela7), com exceção do Mn, os teores de micronutrientes $\mathrm{B}, \mathrm{Cu}, \mathrm{Fe}$ e $\mathrm{Zn}$ encontrados nos grãos foram próximos aos encontrados nas sementes utilizadas.

Assim, pode-se concluir que o manganês foi o único elemento que apresentou concentrações inferiores nos teores de nutrientes nos grãos, tanto em comparação aos valores encontrados na literatura quanto àqueles verificados nas sementes utilizadas no plantio do experimento. No entanto, deve-se ressaltar que as condições de alta disponibilidade de manganês no solo prevaleceram nas condições em que os dados da literatura foram obtidos e, eventualmente, nas áreas de produção das sementes, o que pode ter favorecido a maior concentração desse elemento nos tecidos vegetais, dentre os quais os dos grãos. Nesse sentido, Dechen et al. (1991b) observaram que nas condições tropicais e subtropicais é mais frequente a toxicidade que a deficiência de Mn. 


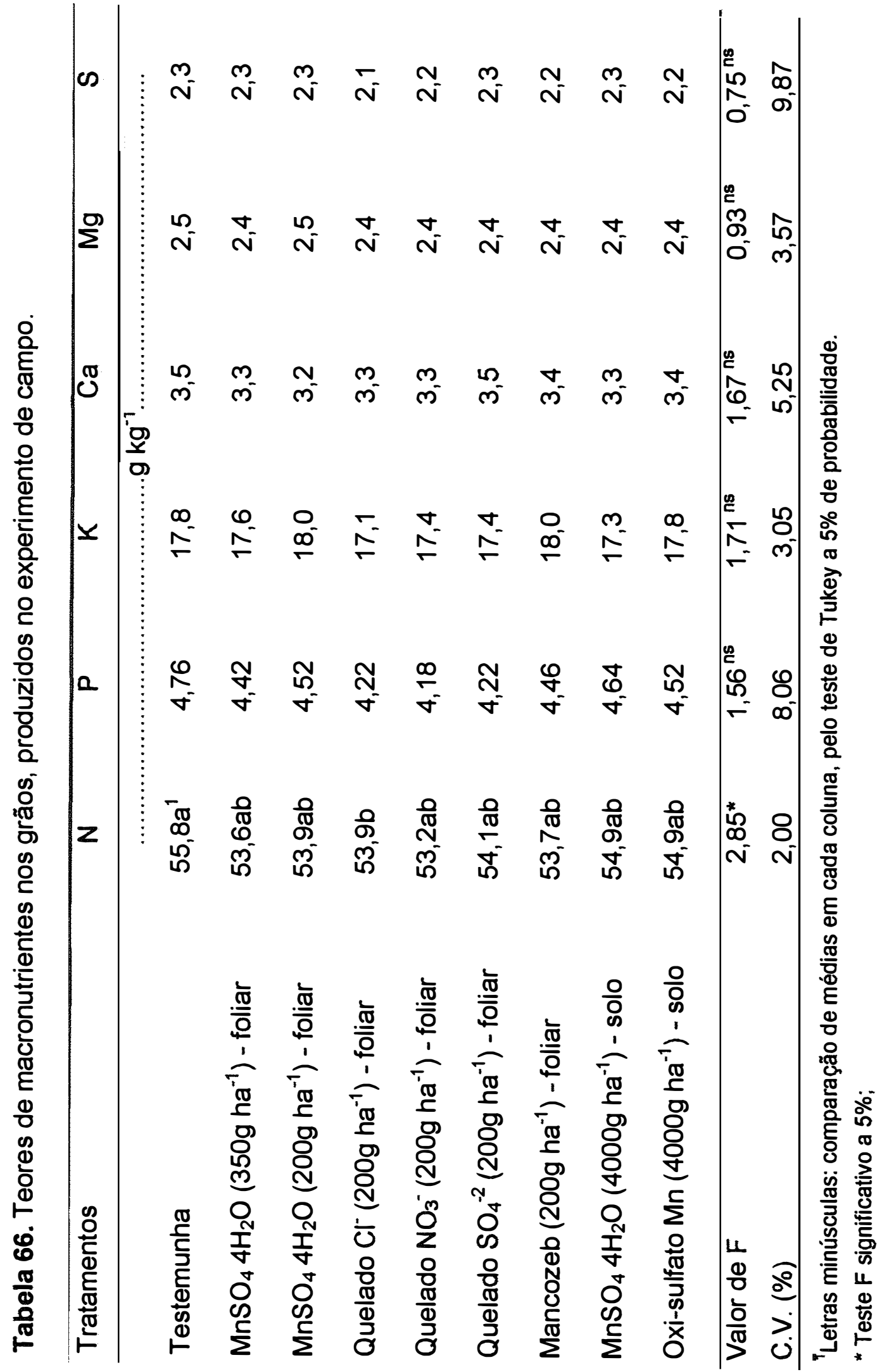




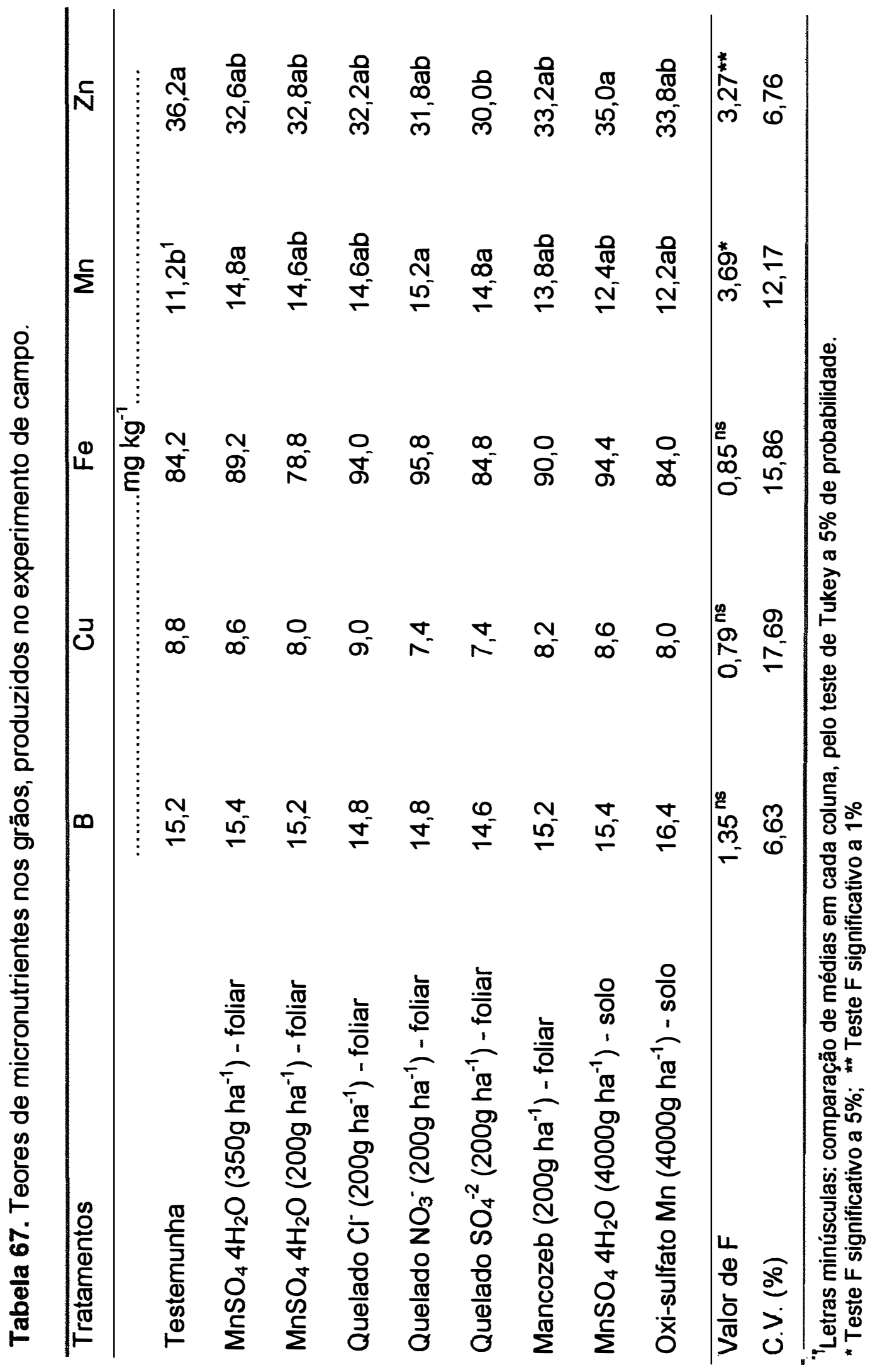


De qualquer modo, as baixas médias do elemento manganês encontrada nos grãos confirmaram o efeito da forte limitação do suprimento do elemento à planta, nas condições em que o experimento foi conduzido.

A ausência de fornecimento de $\mathrm{Mn}$ às plantas resultou em maior concentração de $\mathbf{N}$ nos grãos, conforme observado nos resultados encontrados na testemunha. Esses dados podem estar relacionados à maior concentração de proteína nos grãos, em consequência da deficiência de Mn na planta, de acordo com o verificado por Wilson et al. (1982) e Tanaka et al. (1993).

A relação entre os teores de $\mathrm{Mn}$ e $\mathrm{N}$ nos grãos (Figura 9) demonstrou tendência de aumento nas concentrações de $\mathbf{N}$ em função da redução dos teores de Mn nos grãos.

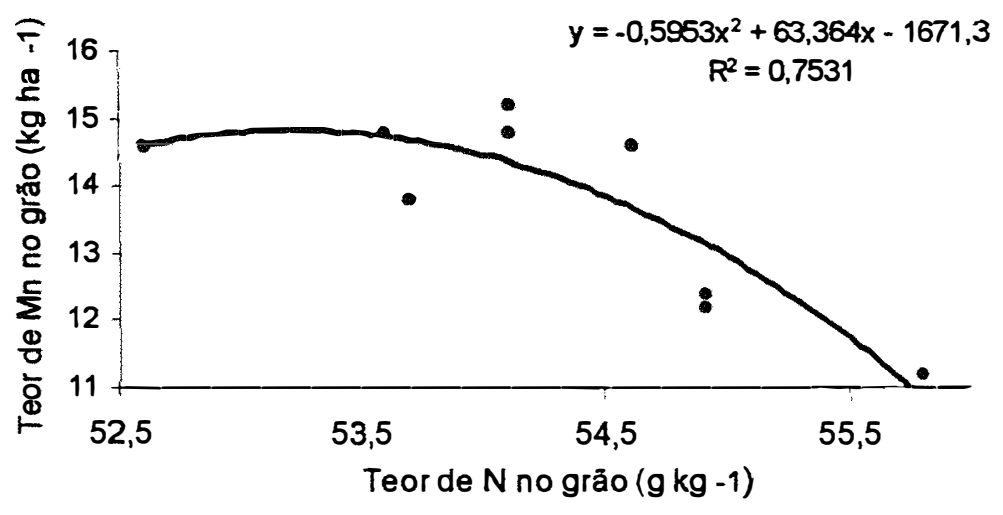

Figura 9. Relação entre teores de $\mathrm{N}$ e $\mathrm{Mn}$ encontrados no grão, no experimento de campo

Os grãos originados das plantas que receberam tratamento via foliar de $\mathrm{MnSO} 44 \mathrm{H}_{2} \mathrm{O}$ (350 g ha- ${ }^{-1}$ ) e quelados $\mathrm{NO}_{3}{ }^{-}$e $\mathrm{SO}_{4}^{-2}$ apresentaram teores de Mn maiores aos observados nas plantas da testemunha. Os demais tratamentos resultaram em niveis intermediários de $\mathrm{Mn}$.

A comparação entre os teores foliares de $\mathrm{Mn}$ com os teores deste elemento encontrados nos grãos encontra-se na Figura 10. 


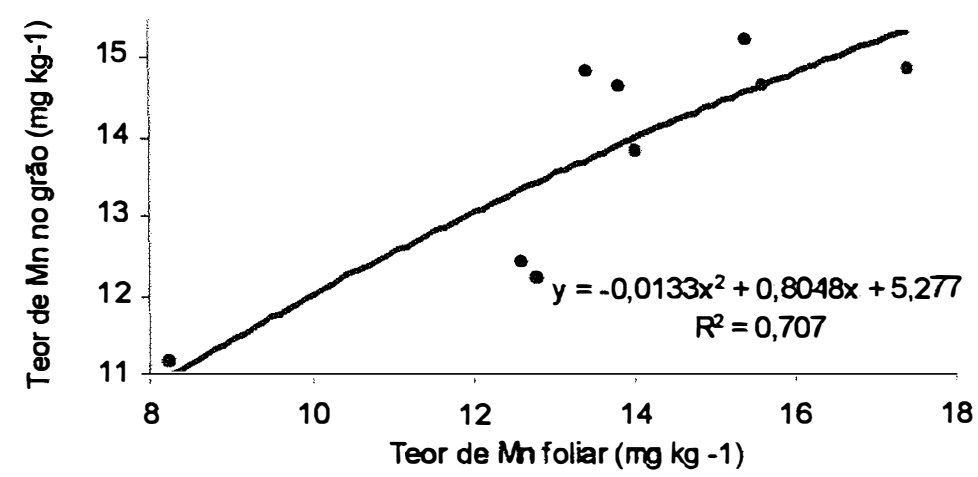

A

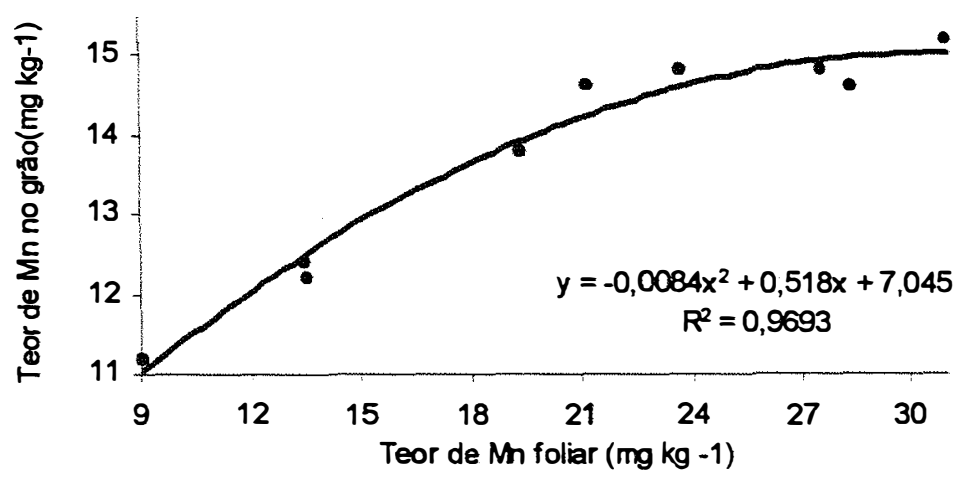

B

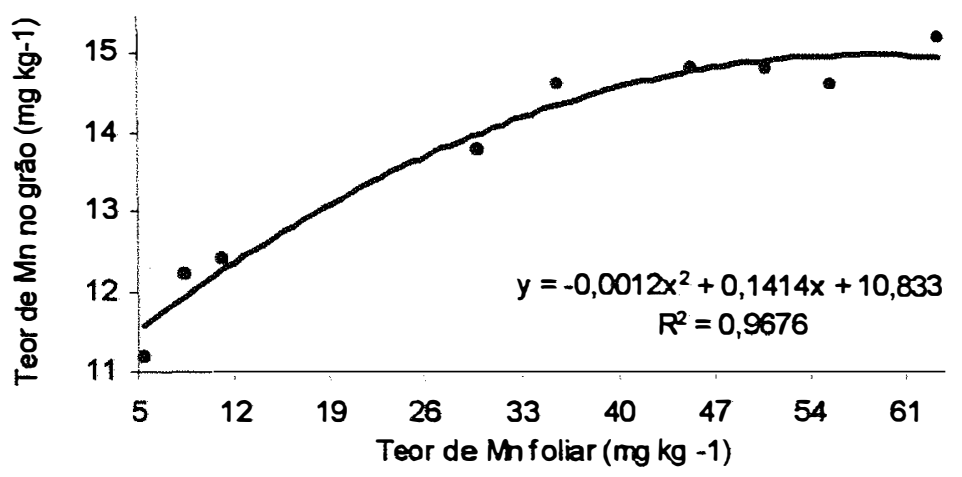

C

Figura 10. Relação entre teor foliar de $\mathrm{Mn}$ e teor de $\mathrm{Mn}$ no grão no experimento de campo: estádio R1 (A), estádio R4 (B) e média dos estádios V4, R1 e R4 (C). 
Comparando-se os teores de Mn nos grãos com os foliares (Figura 9), observou-se que o estado nutricional de $\mathrm{Mn}$, caracterizado pelos seus teores foliares, relacionou-se diretamente com o nivel do elemento nos grãos, confirmando a mesma tendência em relação aos tratamentos, verificada através das análises foliares.

$\mathrm{O}$ efeito interiônico do $\mathrm{Mn}$ sobre $\mathrm{O} \mathrm{Zn}$, concordando com os relatos de Malavolta et al. (1997), pode ser verificado pelo resultados encontrados entre os teores desses elementos nos grãos, em função, principalmente, dos tratamentos via foliar (Tabela 67). Esse efeito interiônico não foi encontrado por. Reddy et al. (1987) em função da aplicação de doses crescentes de Mn, provavelmente pelo fato do elemento ter sido aplicado via solo.

$\mathrm{O}$ aumento dos teores de $\mathrm{Mn}$ resultaram em redução nos niveis de $\mathrm{Zn}$ nos grãos (Figura 11), sendo que a mesma tendência foi observada quando comparados os teores foliares de $\mathrm{Mn}$ e as concentrações de $\mathrm{Zn}$ nos grãos (Figura 12).

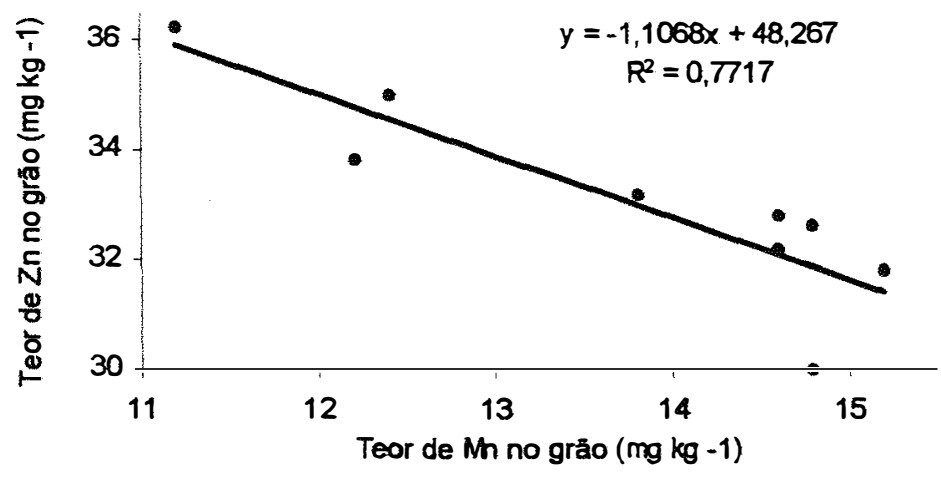

Figura 11. Relação entre teores de Mn e Zn no grão no experimento de campo. 


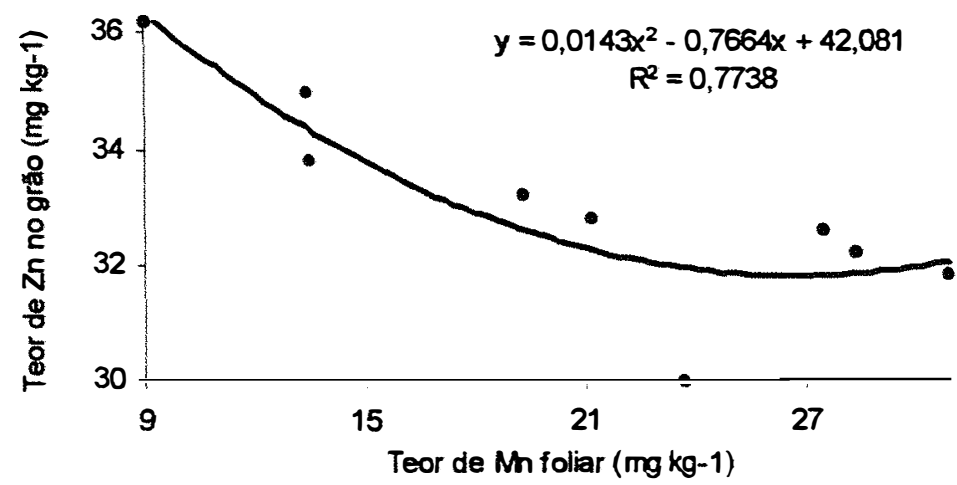

Figura 12. Relação entre teor foliar de Mn (média dos estádios V4, R1 e R4) e teor de Zn no grão no experimento de campo.

\subsubsection{Análises químicas de solo}

Os resultados das análises químicas de solo nas profundidades $0-10$, 10-20 e 0-20 cm apresentados, respectivamente, nas Tabelas 68, 69 e 70 revelaram que, dentre os atributos químicos do solo, apenas os teores de manganês sofreram alterações em função dos tratamentos. No entanto, foram encontradas diferenças na comparação das médias destes atributos, obtidas entre as profundidades amostradas (Tabela 71).

Os valores médios encontrados para os macronutrientes, considerando a chamada camada arável de 0 a $20 \mathrm{~cm}$, foram baixos para $\mathrm{Ke}$ $\mathrm{Ca}$, médios para $\mathrm{P}$ e altos para $\mathrm{Mg}$ e $\mathrm{S}$, segundo os critérios de Raij et al. (1997). Entretanto, verificou-se que o sistema de plantio direto propiciou acúmulo desses elementos na camada mais superficial $(0-10 \mathrm{~cm})$, em função, principalmente, da ausência de movimentação do solo, promovendo-os à classes de teores mais elevadas (médios para $\mathrm{K}$ e $\mathrm{Ca}$ e altos para $\mathrm{P}, \mathrm{Mg}$ e $\mathrm{S}$ ), revelando, portanto, que na área experimental não houve provavelmente limitação em relação ao fornecimento de macronutrientes às plantas. 


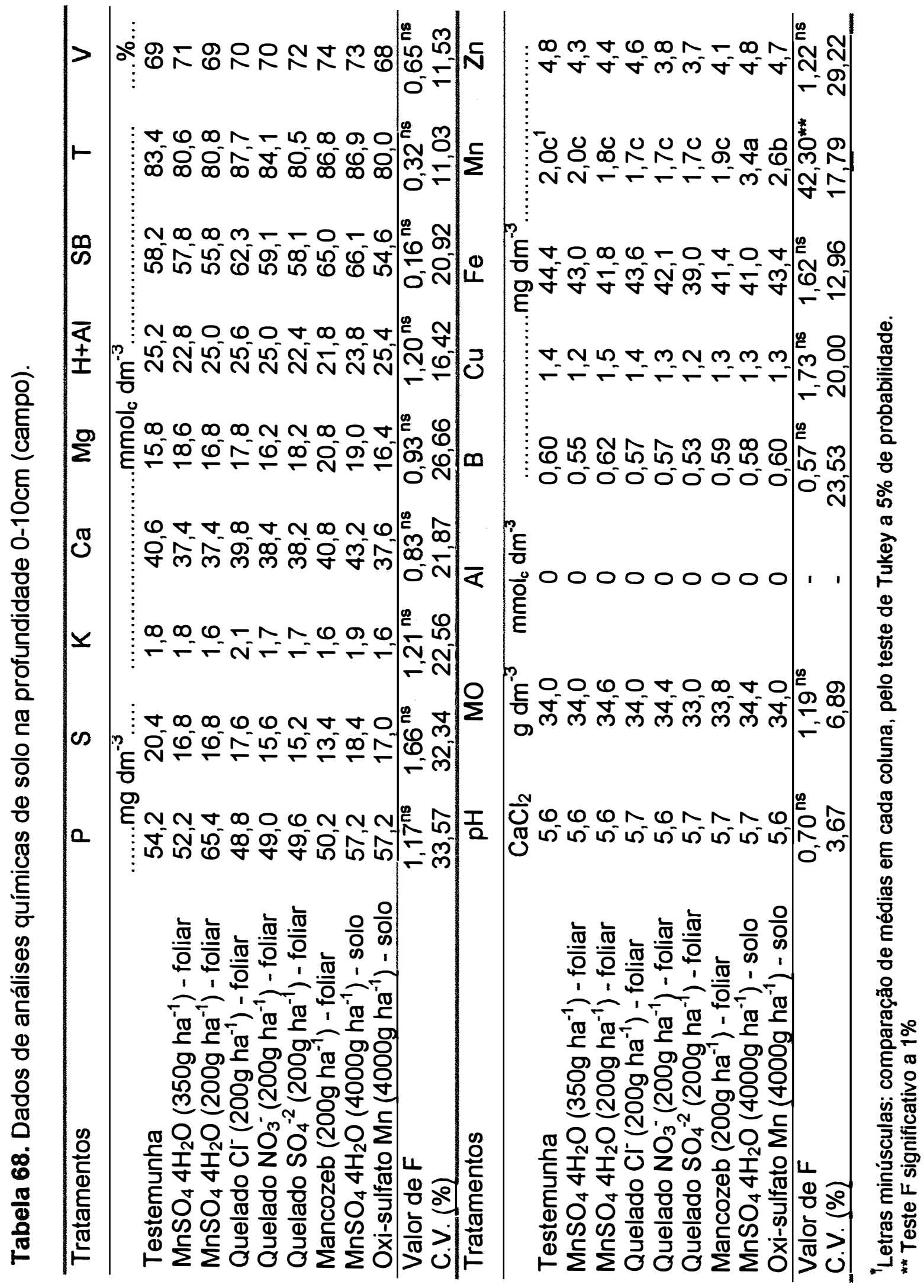




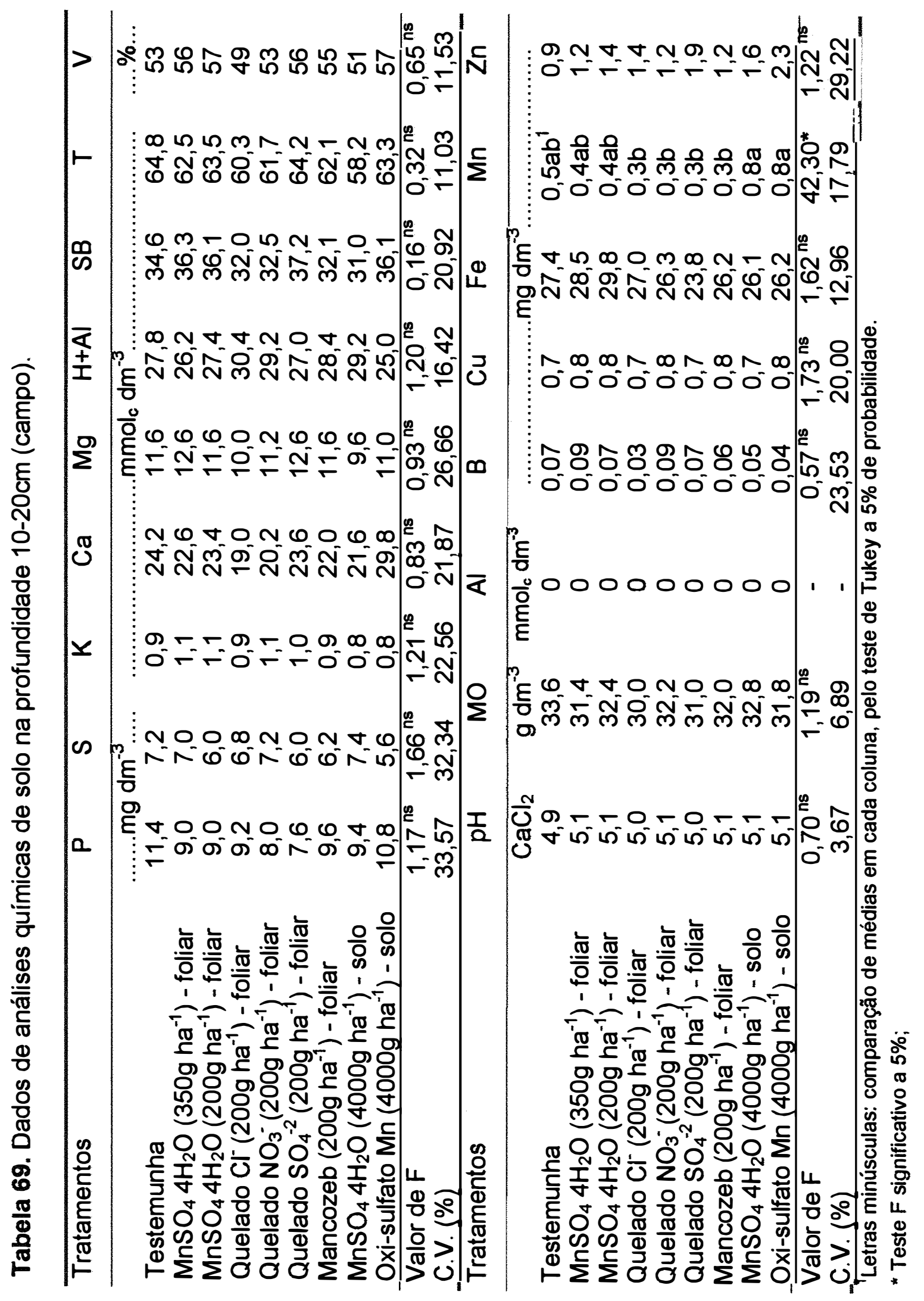




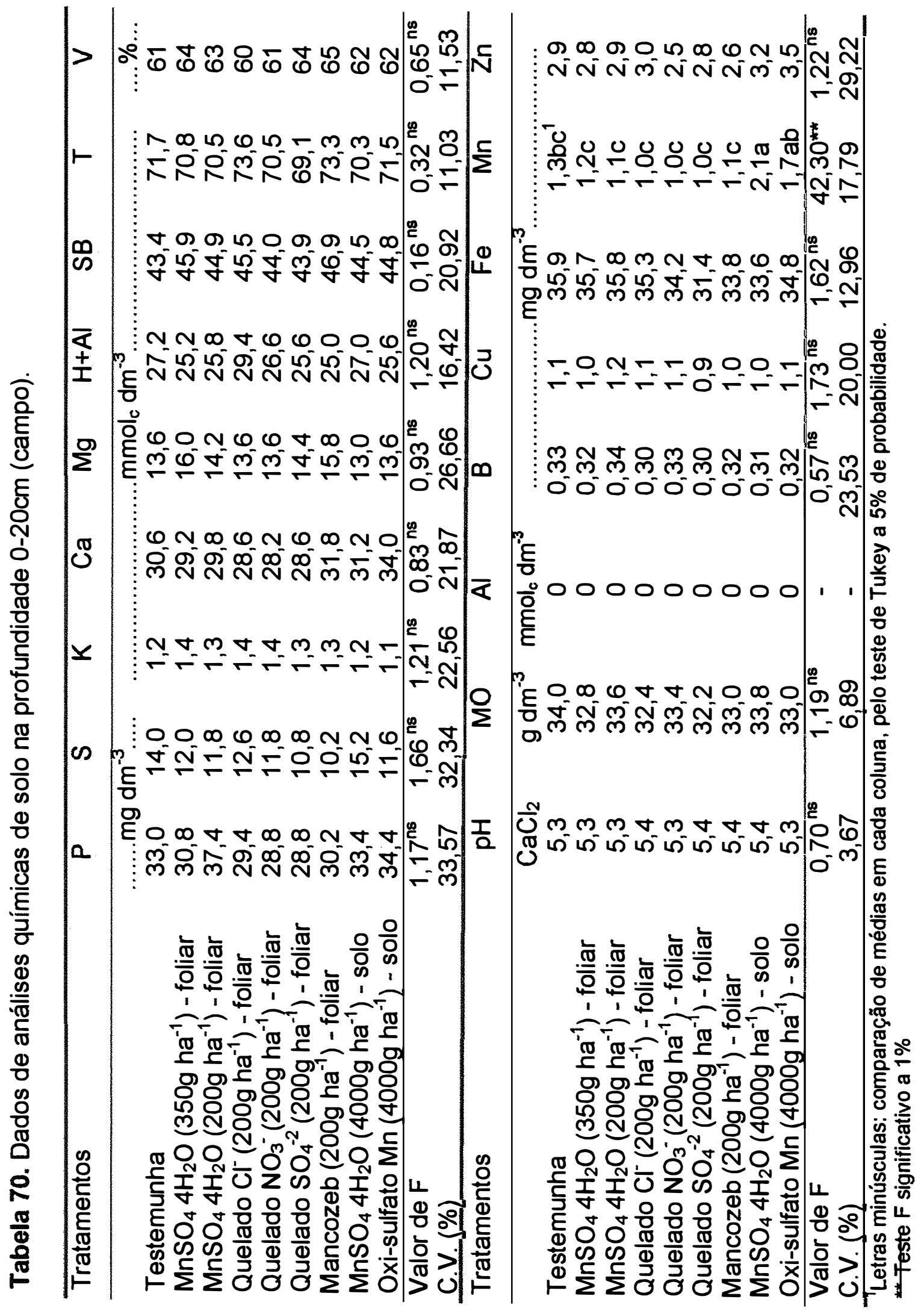




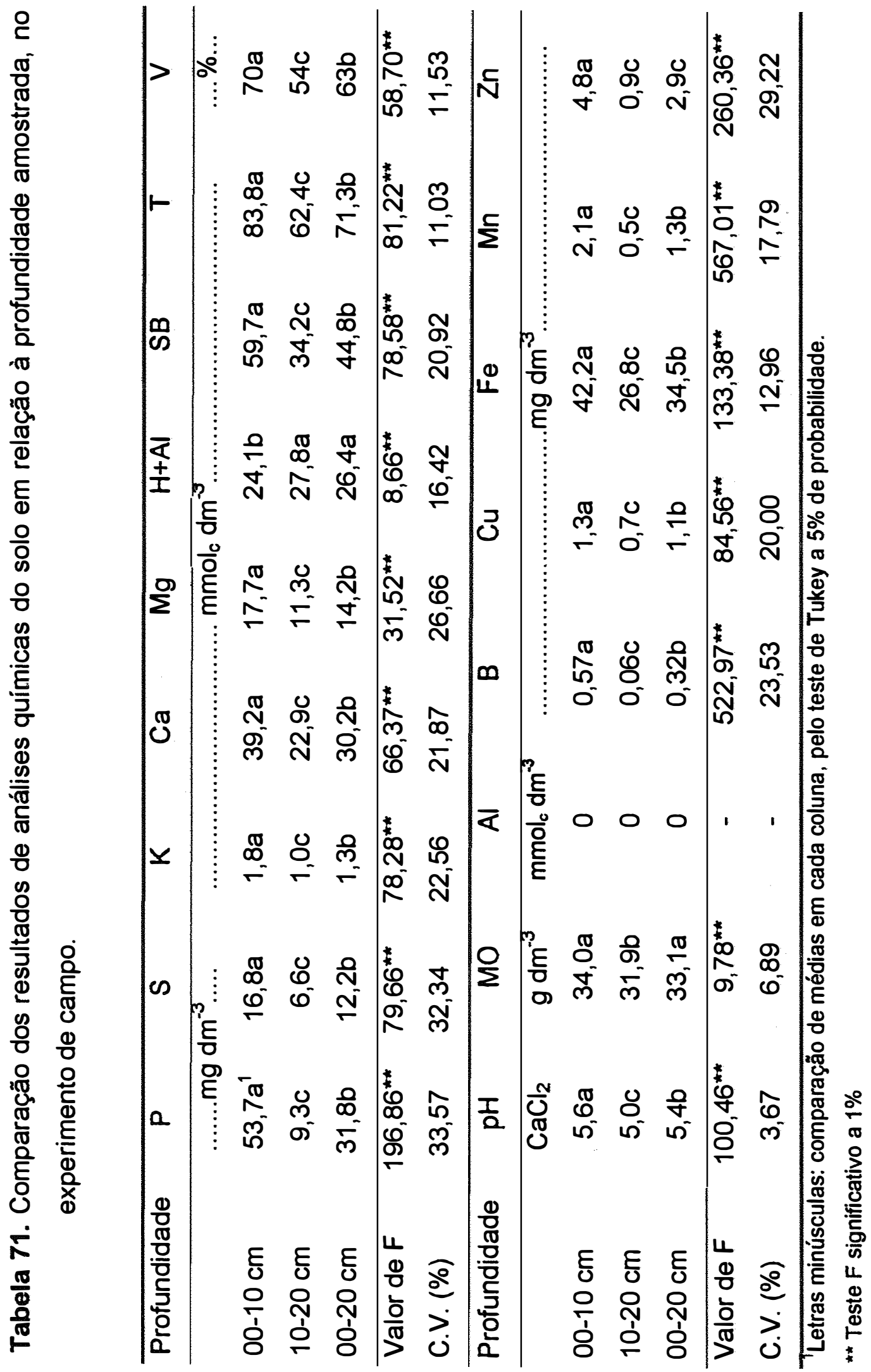


Os teores de $\mathrm{P}$ e $\mathrm{K}$, foram superiores aos encontrados na amostragem realizada anteriormente a implantação do experimento (Tabela13), indicando o efeito da adubação de plantio ( $66 \mathrm{~kg} \mathrm{ha}^{-1}$ de $\mathrm{P}_{2} \mathrm{O}_{5}$ e $60 \mathrm{~kg} \mathrm{ha}^{-1}$ de $\mathrm{K}_{2} \mathrm{O}$ ). Essa variação não foi verificada para $\mathrm{Ca}, \mathrm{Mg}$ e $\mathrm{S}$, uma vez que não foi feito nenhum tipo de adubação contendo estes elementos.

Em relação à saturaçāo por bases (V\%), os resultados foram semelhantes aos encontrados na análise inicial, apresentando valores considerados médios, nas camadas de 10-20 e 0-20 cm, e elevados na região mais próxima à superfície do solo $(0-10 \mathrm{~cm})$, de acordo com os critérios de Sousa et al. (1989), Raij et al. (1997) e Embrapa (1998).

Os resultados de $\mathrm{pH}\left(\mathrm{CaCl}_{2}\right)$, embora tenham apresentados valores de média acidez na camada $0-20 \mathrm{~cm}$, indicaram ocorrência de condições de baixa acidez na camada mais superficial $(0-10 \mathrm{~cm})$ e alta acidez de $10-20 \mathrm{~cm}$ de profundidade.

A comparação desses resultados com a saturação por bases e pH encontrados na camada sub-superficial (Tabela 13), evidenciaram a baixa fertilidade natural e o efeito da correção executada por ocasião da implantação do sistema agrícola nesta área. No entanto, o gradiente encontrado para V\% e $\mathrm{pH}$ dentro da camada de $0-20 \mathrm{~cm}$, inicialmente arável, demonstraram o efeito, mesmo que ainda incipiente, da ausência da movimentação do solo (incorporação dos corretivos), decorrente do sistema de plantio direto.

Os niveis de matéria orgânica, considerados normais para um solo com tal textura, não apresentaram diferença entre os 10 primeiros centímetros de profundidade em relação ao encontrado de $0-20 \mathrm{~cm}$. Entretanto, a pequena diferença encontrada entre a camada 0-10 e $10-20 \mathrm{~cm}$ pode estar indicando um provável início de acúmulo de matéria orgânica, em função do sistema de plantio.

Quanto aos micronutrientes no solo, constatou-se, com exceção do Mn, ausência de deficiência, uma vez que, considerando a camada de $0-20 \mathrm{~cm}$, os teores de $\mathrm{Cu}, \mathrm{Fe}$ e $\mathrm{Zn}$ apresentaram valores considerados altos e os de $\mathrm{B}$, 
teores médios (Embrapa, 1998 e Raij et al., 1997). Esses resultados foram semelhantes aos encontrados na análise realizada antes da implantação do experimento.

Considerando o efeito da profundidade, foi observado acúmulo de micronutrientes na camada mais superficial do solo $(0-10 \mathrm{~cm})$. Nesta camada, os elementos $\mathrm{B}, \mathrm{Cu}, \mathrm{Mn}$ e $\mathrm{Zn}$, apresentaram, respectivamente, teores ao redor $10,2,4$ e 5 vezes superiores em relação à profundidade $10-20 \mathrm{~cm}$. Esse acúmulo pode estar relacionado ao efeito de adubações contendo micronutrientes, realizadas em cultivos anteriores, haja vista que, aparentemente, não houve razões naturais que justificassem a ocorrência de tamanhas diferenças.

Assim, amostragens realizadas em camadas mais próximas à superficie, podem ser mais representativas, principalmente para os micronutrientes, em sistemas de plantio direto.

A aplicação de manganês via solo propiciou elevação nos teores deste elemento em todas as profundidades amostradas, fazendo com que as amostras de solo dos tratamentos $\mathrm{MnSO}_{4} 4 \mathrm{H}_{2} \mathrm{O}$ e oxi-sulfato de $\mathrm{Mn}$, via solo ( $4000 \mathrm{~g} \mathrm{ha}^{-1}$ ), apresentassem, na camada $0-20 \mathrm{~cm}$, teores considerados médios do elemento, enquanto que as demais, mantiveram-se em niveis considerados baixos, ou muito próximos a estes, como foi o caso da testemunha (Tabela 70).

A aplicação via solo de $\mathrm{MnSO}_{4} 4 \mathrm{H}_{2} \mathrm{O}$ propiciou teores de $\mathrm{Mn}$, na camada $0-10 \mathrm{~cm}$, mais elevados que a fonte oxi-sulfato, 0 que pode ser explicado pelo sistema de aplicação uma vez que, a maior solubilidade da primeira em relação à segunda, permitiu melhor distribuição do nutriente nesta camada do solo.

Entretanto, a exemplo dos outros micronutrientes, quando considerados os teores encontrados na camada $0-10 \mathrm{~cm}$, verificou-se que todos os niveis de $\mathrm{Mn}$ encontrados apresentaram teores considerados suficientes para a cultura. 
Portanto, quer seja pelo aumento do teor de $\mathrm{Mn}$ no solo, promovido pelas fontes aplicadas, quer seja pelos niveis considerados suficientes, na camada mais superficial, foi verificado que nos dois casos, a simples presença do elemento no solo, conforme observado nos experimentos em casa de vegetação, não foi capaz de suprir o elemento à planta, uma vez que, não foi possivel estabelecer relações entre os teores do elemento no solo com qualquer um dos resultados das avaliações efetuadas na planta.

Em vista do exposto, pode-se afirmar que, independentemente do potencial genético da planta para a absorção radicular do $\mathrm{Mn}$, as condições do solo, principalmente na superfície, interferiram negativamente na disponibilidade do manganês à planta.

Assim como também foi verificado por vários autores (Randall et al., 1975a,b; Parker et al., 1981; Ritchey et al., 1981; Quaggio et al., 1982; Reddy et al., 1987; Novais et al., 1989; Tanaka et al., 1992 e Santos, 1999), as condições de baixa acidez encontradas na superfície do solo, podem, por diferentes razões, ter reduzido a disponibilidade do Mn para a planta.

Além do $\mathrm{pH}$, pode-se afirmar que os altos teores de $\mathrm{P}, \mathrm{Mg}, \mathrm{Cu}, \mathrm{Fe} e$ $\mathrm{Zn}$, encontrados na camada superficial, contribuíram para comprometer o aproveitamento do manganês pela planta (Marinho, 1988; Malavolta et al., 1991; Malavolta et al., 1997 e Vitti \& Luz, 1998).

O desenvolvimento do sistema radicular das plantas em direção a camadas mais profundas, fora portanto da região sob os efeitos relatados, não possibilitou a correção da deficiência de Mn, ao contrário do observado por Tanaka et al. (1989), uma vez que nessas camadas os teores de manganês encontravam-se muito baixos.

Assim, conforme também relatou Volkweiss (1991), ficou justificado os melhores resultados encontrados pelo fornecimento do manganês via foliar, o qual possibilitou maior aproveitamento do elemento pela planta, ao impedir que o elemento ficasse sujeito a tais condições de solo. 


\subsubsection{Teor de óleo e proteína}

Os resultados obtidos pela determinação dos teores de óleo e proteína nos grãos, apresentados na Tabela 72 , revelaram a ocorrência de diferenças em função dos tratamentos.

Tabela 72. Dados de teor de óleo e proteína do experimento de campo.

\begin{tabular}{|c|c|c|}
\hline Tratamentos & Teor de óleo & Teor de proteína \\
\hline & $\ldots \% \ldots \ldots$ & ........\%........ \\
\hline Testemunha & $23,38 b^{1}$ & $42,55 a$ \\
\hline $\mathrm{MnSO}_{4} 4 \mathrm{H}_{2} \mathrm{O}\left(350 \mathrm{~g} \mathrm{ha}^{-1}\right)$ - foliar & $25,25 a$ & $40,53 b$ \\
\hline $\mathrm{MnSO}_{4} 4 \mathrm{H}_{2} \mathrm{O}\left(200 \mathrm{~g} \mathrm{ha}^{-1}\right)$ - foliar & $25,07 a b$ & $40,73 a b$ \\
\hline Quelado $\mathrm{Cl}^{-}\left(200 \mathrm{~g} \mathrm{ha}^{-1}\right)$ - foliar & $25,72 a$ & $40,53 b$ \\
\hline Quelado $\mathrm{NO}_{3}^{-}\left(200 \mathrm{~g} \mathrm{ha}^{-1}\right)$ - foliar & $25,31 a$ & $40,25 b$ \\
\hline Quelado $\mathrm{SO}_{4}^{-2}\left(200 \mathrm{~g} \mathrm{ha}^{-1}\right)$ - foliar & $25,37 a$ & $40,41 b$ \\
\hline Mancozeb (200 g ha-1 $)$ - foliar & $25,31 a$ & $40,77 a b$ \\
\hline $\mathrm{MnSO}_{4} 4 \mathrm{H}_{2} \mathrm{O}\left(4000 \mathrm{~g} \mathrm{ha}^{-1}\right)$ - solo & $24,96 a b$ & $40,81 a b$ \\
\hline Oxi-sulfato Mn (4000g ha-1) - solo & $24,80 a b$ & $40,75 a b$ \\
\hline Valor de F & $2,89^{\star \star}$ & $2,29^{\star}$ \\
\hline C.V. (\%) & 3,51 & 2,35 \\
\hline
\end{tabular}

Letras minúsculas: comparação em cada coluna, pelo teste de Tukey a $5 \%$ de probabilidade. *Feste-F significativo a 5\%; ** Teste F significativo a $1 \%$

Os menores teores de óleo foram encontrados nos grãos das plantas que não receberam manganês (testemunha) e os maiores obtidos em grãos oriundos de plantas que receberam aplicação foliar de quelados de manganês e $\mathrm{MnSO}_{4} 4 \mathrm{H}_{2} \mathrm{O}$ (350 g/ha). A aplicação de $\mathrm{Mn}$ via solo e a aplicação foliar de $\mathrm{MnSO}_{4} 4 \mathrm{H}_{2} \mathrm{O}$ (200 g/ha) resultaram em teores intermediários de óleo.

Os resultados mostraram correlação positiva entre os teores foliares de manganês e produção de óleo pelo grão (Figura 13). 


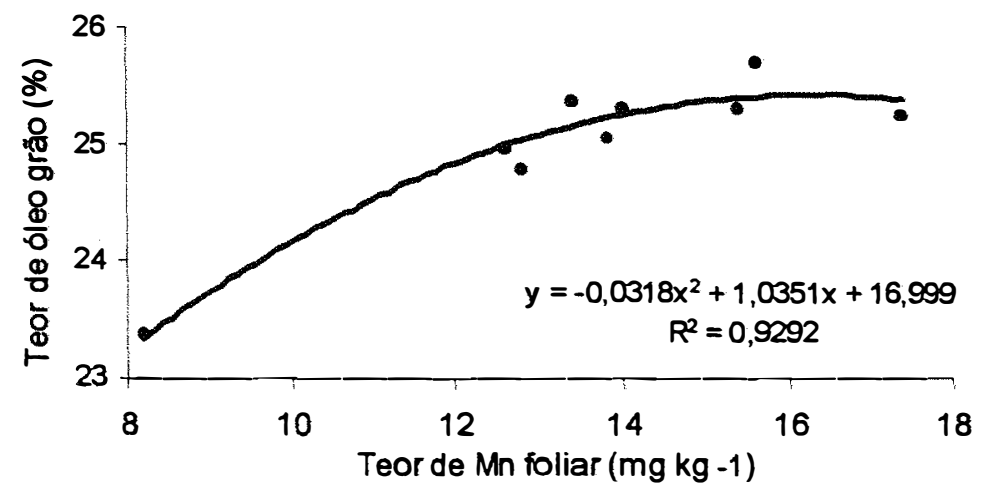

A

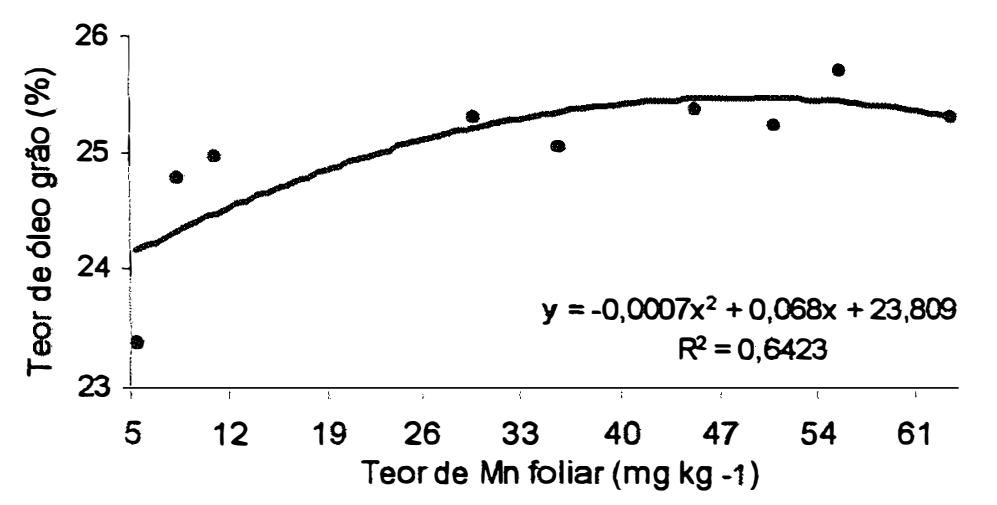

B

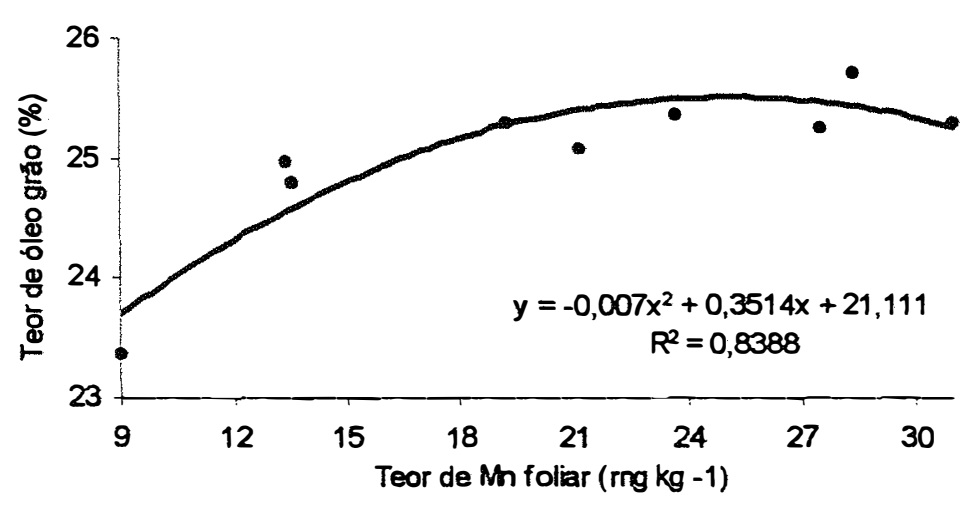

C

Figura 13. Relação entre teor foliar de $M n$ e teor de óleo no grão no experimento de campo: estádio R1 (A), estádio R4 (B) e média dos estádios V4, R1 e R4 (C). 
Em relação a proteina, os resultados demonstraram que os maiores teores foram encontrados nos grãos da testemunha e, os menores, naqueles das plantas que receberam aplicação de manganês via foliar, através das fontes $\mathrm{MnSO}_{4} 4 \mathrm{H}_{2} \mathrm{O}$ (350 g/ha) e quelados. Os tratamentos via solo e a aplicação foliar de $\mathrm{MnSO}_{4} 4 \mathrm{H}_{2} \mathrm{O}$ (200 g/ha) e mancozeb resultaram em teores de proteína intermediários aos demais.

Nesse caso, a correlação entre teor foliar de manganês e concentração de proteína nos grãos foi negativa (Figura 14).

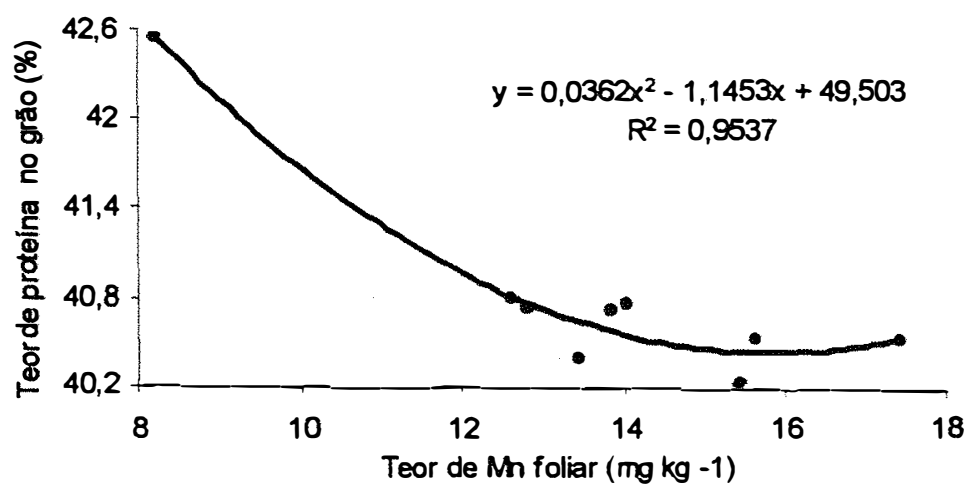

A

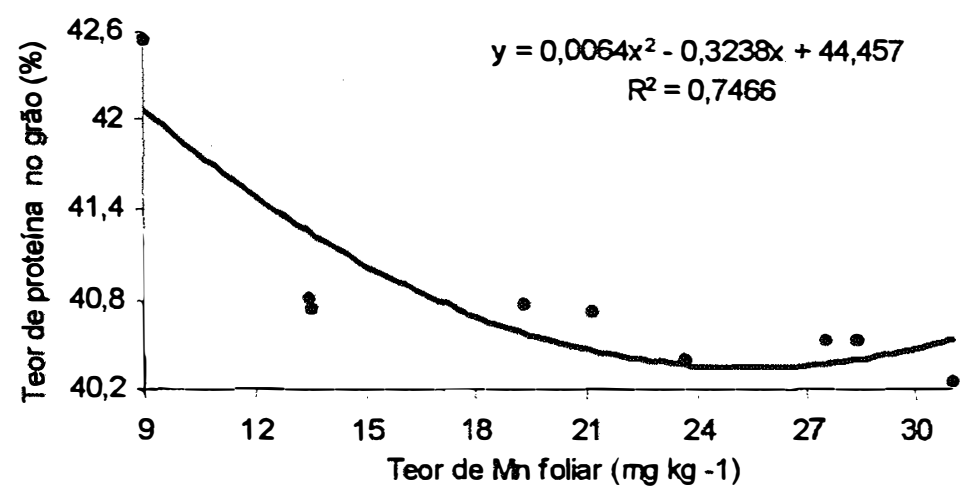

B

Figura 14. Relação entre teor foliar de $M n$ e teor de proteína no grão no experimento de campo: estádio R1 (A) e média dos estádios V4, R1 e R4 (B). 
As regressões polinomiais, revelaram que os niveis foliares de manganês no estádio R1 foram os que melhor se relacionaram tanto com os teores de óleo quanto com os de proteína nos grãos. Resultados semelhantes foram obtidos nos trabalhos de Wilson et al. (1982), Tanaka \& Mascarenhas (1992) e Tanaka et al. (1993). Assim, a deficiência de manganês resultou em queda nos teores de óleo e acréscimo nas concentrações de proteína, concluindo-se que o aumento na concentração de óleo nos grãos está relacionada com redução na concentração de proteína (Figura 15) estando de acordo com o observado na literatura citada.

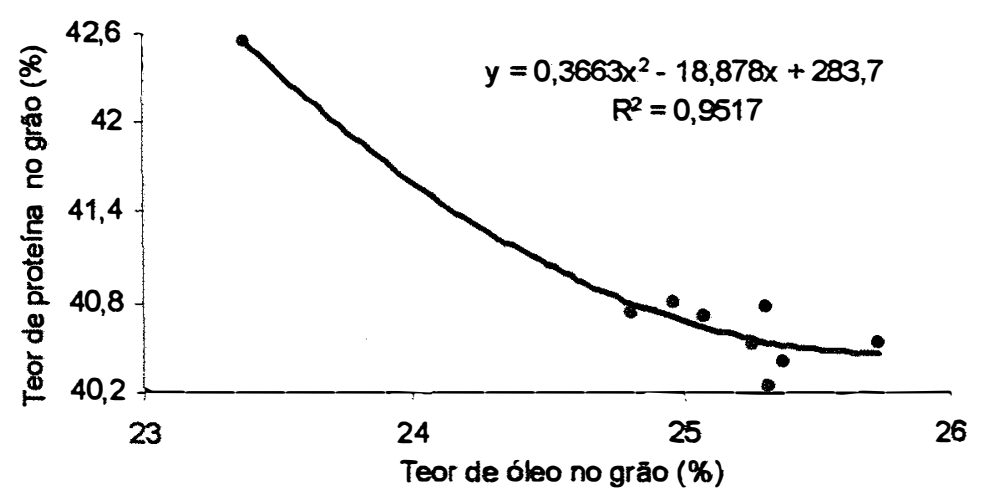

Figura 15. Relação entre teores de óleo e proteína no grão no experimento de campo.

A comparação dos dados dos níveis de manganês encontrados nos grãos com as concentrações de óleo e proteína (Figura 16) revelaram que quanto maiores os teores de $\mathrm{Mn}$ nos grãos menores os teores de óleo e maiores os de proteína, assim como havia sido verificado entre os teores foliares de manganês e os de óleo e proteína nos grãos. 


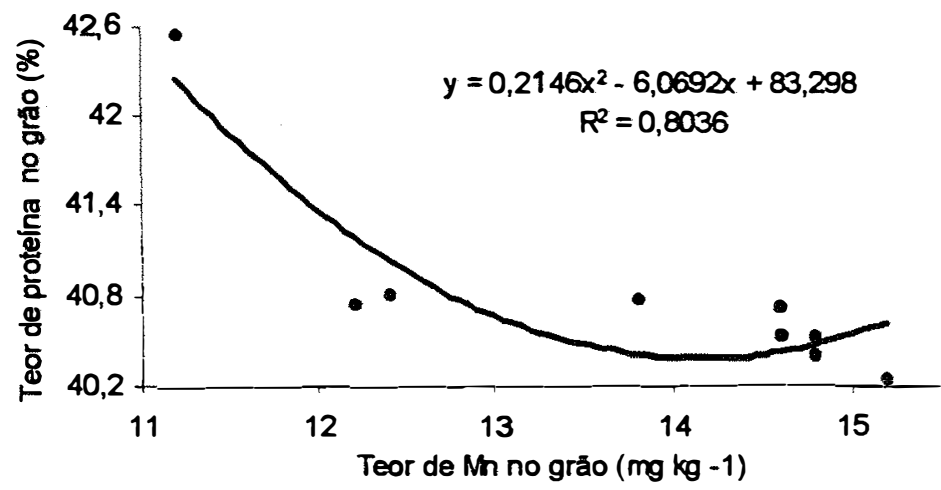

A

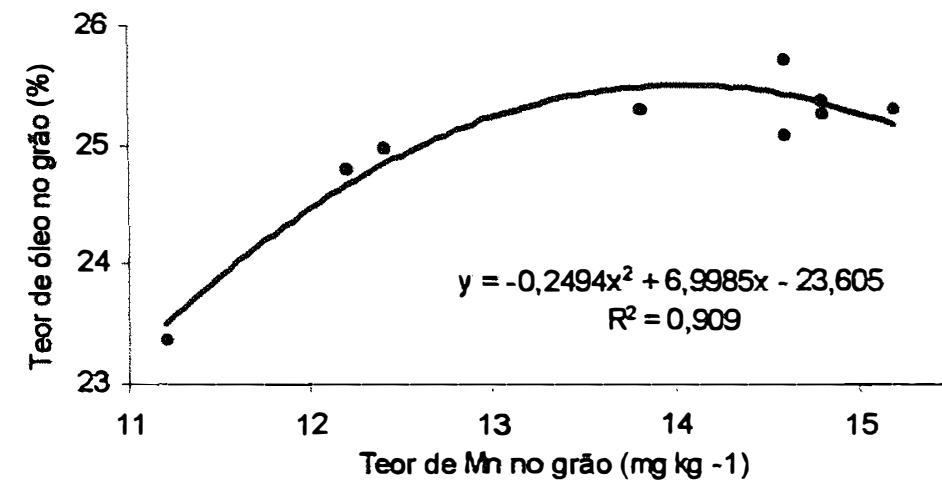

B

Figura 16. Relação entre teores de $M n$ e proteína (A) e $M n$ e óleo (B) encontrados nos grãos no experimento de campo.

A influência do aumento das concentrações de manganês sobre a redução nos teores de zinco nos grãos, conforme já comentado, levaram a um comportamento inverso ao do manganês em relação às concentrações de óleo e proteína nos grãos. Assim, no caso da concentração de zinco nos grãos, constatou-se que o seu aumento resultou em redução nos teores de proteína e aumento nos teores de óleo no grão (Figura 17). 


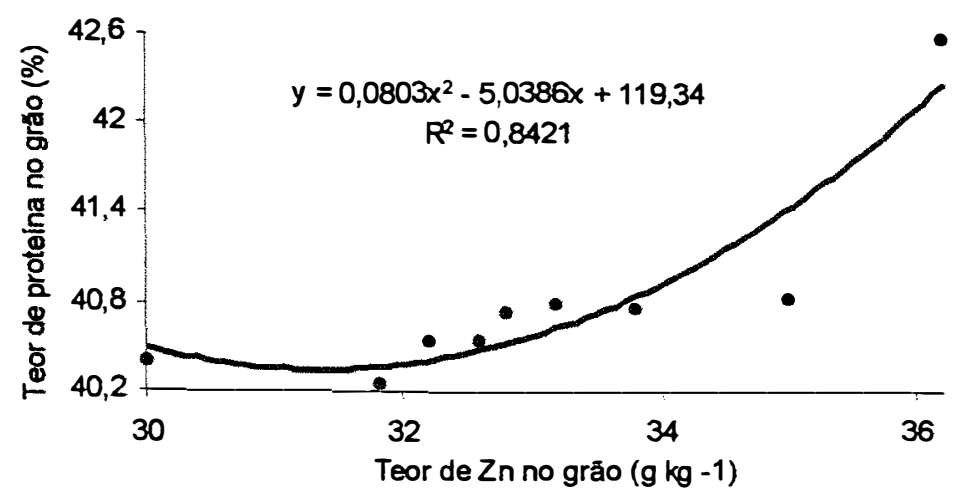

A

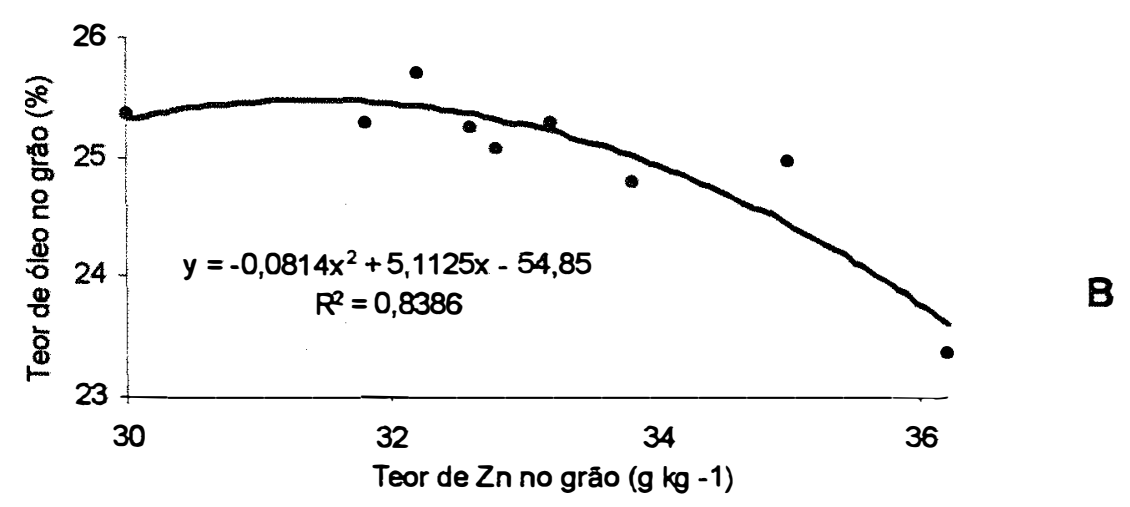

Figura 17. Relação entre teores de $\mathrm{Zn}$ e proteina (A) e $\mathrm{Zn}$ e óleo (B) encontrados no grão no experimento de campo.

\subsubsection{Avaliação da qualidade das sementes}

Os dados médios de massa de mil sementes estão apresentados na Tabela 73. Pode-se verificar um agrupamento das médias, sendo que as plantas da testemunha produziram sementes mais leves do que aquelas dos demais tratamentos, que por sua vez não diferiram entre si. Estes resultados indicaram que a aplicação de manganês exerceu influência positiva sobre a massa de mil sementes. 
Convém salientar que a massa de mil sementes é um dado importante, que pode dar idéia a respeito da qualidade das sementes bem como fornecer informações que facilitarão o cálculo para semeadura e regulagens de semeadoras (Marcos Filho et al., 1987). Além disso, a redução na massa indica menor acúmulo de reservas, interferindo diretamente na qualidade do seu uso como semente.

Tabela 73. Massa de mil sementes do experimento de campo.

\begin{tabular}{|c|c|}
\hline Tratamentos & Massa de mil sementes \\
\hline & 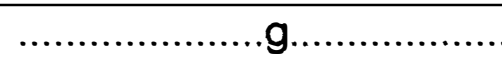 \\
\hline Testemunha & $107,0 b^{1}$ \\
\hline $\mathrm{MnSO}_{4} 4 \mathrm{H}_{2} \mathrm{O}\left(350 \mathrm{~g} \mathrm{ha}^{-1}\right)$ - foliar & $123,2 a$ \\
\hline $\mathrm{MnSO}_{4} 4 \mathrm{H}_{2} \mathrm{O}\left(200 \mathrm{~g} \mathrm{ha}^{-1}\right)$ - foliar & $120,8 a$ \\
\hline Quelado $\mathrm{Cl}^{-}\left(200 \mathrm{~g} \mathrm{ha}^{-1}\right)$ - foliar & $122,9 a$ \\
\hline Quelado $\mathrm{NO}_{3}^{-}\left(200 \mathrm{~g} \mathrm{ha}^{-1}\right)$ - foliar & $120,8 a$ \\
\hline Quelado $\mathrm{SO}_{4}^{-2}\left(200 \mathrm{~g} \mathrm{ha}^{-1}\right)$ - foliar & $122,5 a$ \\
\hline Mancozeb (200 g ha $\left.{ }^{-1}\right)$ - foliar & $120,6 a$ \\
\hline $\mathrm{MnSO}_{4} 4 \mathrm{H}_{2} \mathrm{O}\left(4000 \mathrm{~g} \mathrm{ha}^{-1}\right)$ - solo & $121,2 a$ \\
\hline Oxi-sulfato Mn (4000g ha-1) - solo & $117,7 a$ \\
\hline Valor de F & $25,43^{\star \star}$ \\
\hline C.V. (\%) & 3,18 \\
\hline
\end{tabular}

$\mathrm{Na}$ Figura 18 está representada a relação entre teor foliar de manganês e massa de mil sementes. No estádio R1 e na média dos três estádios, as regressões polinomiais revelaram que o teor foliar de manganês pode interferir no massa de mil sementes, demonstrando que o aumento no teor 
foliar de $\mathrm{Mn}$ refletiu em um incremento no massa de mil sementes. No estádio R4, não foi verificada correlação significativa entre os dois parâmetros.

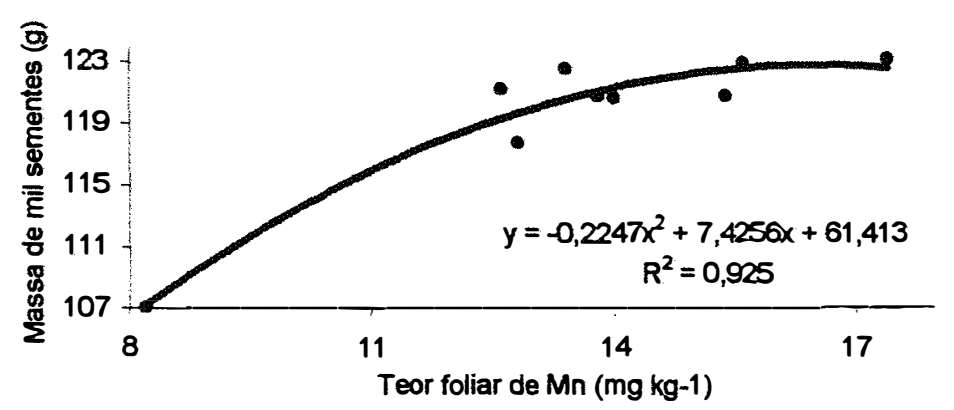

A

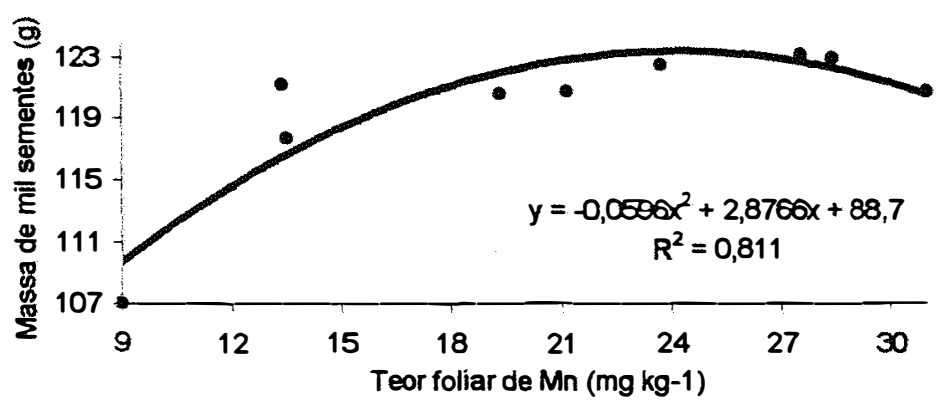

B

Figura 18. Relação entre teor foliar de $M n$ e massa de mil sementes no experimento de campo: estádio R1 (A) e média dos estádios V4, R1 e R4 (B).

$\mathrm{Na}$ Tabela 74 estão apresentados os valores médios referentes ao grau de umidade, germinação, envelhecimento acelerado e condutividade elétrica, em função dos tratamentos.

Os dados de grau de umidade das sementes, embora não tenham sido analisados estatisticamente, foram, de um modo geral, semelhantes para 
os nove tratamentos estudados. Este fato é muito importante na execução dos testes, considerando-se que a uniformização da umidade das sementes é imprescindivel para a padronização das avaliações e obtenção de resultados consistentes (Matthews, 1981; Marcos Filho et al., 1987 e Loeffler et al., 1988). De acordo com Marcos Filho (1999), diferenças de 1 a $2 \%$ não são comprometedoras.

Tabela 74. Dados médios de grau de umidade (GU) antes da realização dos testes, germinação (G) e vigor, avaliado através do envelhecimento acelerado (EA) e da condutividade elétrica (CE) de sementes de soja.

\begin{tabular}{|c|c|c|c|c|}
\hline \multirow[t]{2}{*}{ Tratamentos } & \multirow[t]{2}{*}{ GU } & \multirow[t]{2}{*}{$\mathbf{G}$} & \multicolumn{2}{|r|}{ Vigor } \\
\hline & & & EA & CE \\
\hline & ........ &..$\% \ldots$ & ....... & $\mu \mathrm{mho} \mathrm{cm}^{-1} \mathrm{~g}^{-1}$ \\
\hline Testemunha & 10,0 & 84 & 82 & $81,7 b^{1}$ \\
\hline $\mathrm{MnSO}_{4} 4 \mathrm{H}_{2} \mathrm{O}\left(350 \mathrm{~g} \mathrm{ha}^{-1}\right)$ - foliar & 10,3 & 94 & 88 & $63,8 a$ \\
\hline $\mathrm{MnSO}_{4} 4 \mathrm{H}_{2} \mathrm{O}\left(200 \mathrm{~g} \mathrm{ha}^{-1}\right)$ - foliar & 10,0 & 91 & 86 & $66,6 a$ \\
\hline Quelado $\mathrm{Cl}^{-}\left(200 \mathrm{~g} \mathrm{ha}^{-1}\right)$ - foliar & 9,9 & 95 & 87 & $66,0 a$ \\
\hline Quelado $\mathrm{NO}_{3}^{-}\left(200 \mathrm{~g} \mathrm{ha}^{-1}\right)$ - foliar & 10,0 & 91 & 87 & $65,0 a$ \\
\hline Quelado $\mathrm{SO}_{4}^{-2}\left(200 \mathrm{~g} \mathrm{ha}^{-1}\right)$ - foliar & 10,0 & 90 & 87 & $64,8 a$ \\
\hline Mancozeb (200 g ha $\left.{ }^{-1}\right)$ - foliar & 9,8 & 86 & 84 & $67,9 a b$ \\
\hline $\mathrm{MnSO}_{4} 4 \mathrm{H}_{2} \mathrm{O}\left(4000 \mathrm{~g} \mathrm{ha}^{-1}\right)$ - solo & 9,0 & 91 & 84 & $74,5 a b$ \\
\hline Oxi-sulfato Mn (4000g ha $\left.{ }^{-1}\right)$ - solo & 9,2 & 92 & 87 & $74,7 a b$ \\
\hline Valor de F & - & $1,58^{\text {ns }}$ & $0,44^{\text {ns }}$ & $3,76^{\star \star}$ \\
\hline C.V. (\%) & - & 8,36 & 8,25 & 9,15 \\
\hline
\end{tabular}

\footnotetext{
'Letras minúsculas: comparação em cada coluna, pelo teste de Tukey a $5 \%$ de probabilidade.
} Teste F significativo a $1 \%$ 
Pelos resultados de germinação pode-se notar que não foram detectadas diferenças entre os tratamentos. Com exceção da testemunha e do Mancozeb (200 $\mathrm{g} \mathrm{ha}^{-1}$, via foliar), os demais tratamentos apresentaram germinação superior a $90 \%$; contudo, todos acima do padrão mínimo para comercialização, ou seja, 80\% (Brasil, 1993). Assim, o teste de germinação não se revelou capaz de mostrar diferenças entre a qualidade fisiológica dos tratamentos. Entretanto, foi observada uma ligeira tendência de inferioridade para a testemunha.

Com relação ao vigor, avaliado pelo envelhecimento acelerado (EA), verificou-se que não houve diferenças entre os tratamentos; porém, a testemunha apresentou o menor valor de germinação, após o período de envelhecimento artificial, em comparação aos tratamentos que receberam manganês.

Por outro lado, o vigor avaliado pelo teste de condutividade elétrica (CE) apontou os tratamentos $\mathrm{MnSO}_{4} 4 \mathrm{H}_{2} \mathrm{O}$ (350 e $200 \mathrm{~g} \mathrm{ha}^{-1}$, via foliar), quelado $\mathrm{Cl}$ (200 $\mathrm{g} \mathrm{ha}^{-1}$, via foliar) e quelado $\mathrm{SO}_{4}^{-2}$ (200 $\mathrm{g} \mathrm{ha}^{-1}$, via foliar) como superiores, embora não tenham diferido dos tratamentos mancozeb (200 g ha-1, via foliar), $\mathrm{MnSO}_{4} 4 \mathrm{H}_{2} \mathrm{O}$ (4000 $\mathrm{g} \mathrm{ha}^{-1}$, via solo) e oxi-sulfato $\mathrm{Mn}$ (4000 $\mathrm{g} \mathrm{ha}^{-1}$, via solo), enquanto que a testemunha foi identificada como a de pior qualidade fisiológica. Dessa forma, pode-se observar que o teste foi sensivel para separar os tratamentos em niveis de vigor, sendo que a testemunha apresentou o valor mais alto de condutividade (maior liberação de exsudatos), estando relacionado a sementes de qualidade inferior, revelando, assim, maior intensidade de desorganização dos sistemas membranais das células (Vieira \& Krzyzanovski, 1999).

É importante ressaltar que, no caso de soja, sementes com condutividade elétrica até $60-70 \mu \mathrm{mho} \mathrm{cm}^{-1} \mathrm{~g}^{-1}$ têm sido consideradas como de alto vigor, enquanto $70-80 \mu \mathrm{mho} \mathrm{cm}^{-1} \mathrm{~g}^{-1}$ já são valores com tendência para médio vigor (Vieira, 1994). 
O manganês está relacionado à formação da lignina (Heenam \& Campbell). A lignina, por sua vez, é uma das substâncias presentes na parede celular que apresenta características de impermeabilização (McDougall et al., 1996), podendo exercer, portanto, efeito significativo sobre a capacidade e a velocidade de absorção de água através do tegumento, alterando desse modo a quantidade de lixiviados liberados para o meio externo (Panobianco et al., 1999). Estes autores verificaram que teores mais baixos de lignina no tegumento de sementes de soja relacionaram-se a valores mais altos de condutividade elétrica.

Diante do exposto, pode-se concluir que o estado nutricional das plantas de soja, em relação ao manganês, influenciou a qualidade fisiológica da semente, como revelado pelo teste de condutividade elétrica, sendo que a aplicação foliar de sais ou quelados de manganês apresentaram tendência de melhores resultados na qualidade das sementes produzidas, pelos parâmetros considerados. 


\section{CONCLUSÕES}

A análise dos dados e a interpretação dos resultados permitiram concluir que, nas condições estudadas:

a) Não foi possível corrigir-se a deficiência de manganês pela aplicação desse micronutriente via solo ou semente, nem tão pouco encontrouse relação entre a concentração do elemento na planta com seu teor no solo;

b) A aplicação de manganês via foliar em dois parcelamentos (V4 e R1) utilizando fontes quelatizadas, sais ou mesmo mancozeb, mostraram-se superiores e mais eficientes que o fornecimento do elemento via solo;

c) As fontes quelatizadas foram equivalentes entre si, apresentando, quanto à dose, eficiência superior à fonte mineral e ao mancozeb;

d) A leitura do teor de pigmento na folha apresentou, em condições de campo, boa correlação com os teores foliares de $\mathrm{Mn}$, indicando grande potencial para diagnose rápida do estado nutricional das plantas de soja para 0 $\mathrm{Mn}$;

e) Houve aumento na produção de grãos pelo fornecimento de Mn via foliar, assim como nas concentrações de óleo nos grãos;

f) A qualidade das sementes foi influenciada positivamente pelo fornecimento de manganês. 


\section{REFERÊNCIAS BIBLIOGRÁFICAS}

ABREU, C.A.; NOVAIS, R.F.; RAIJ, B. van; RIBEIRO, A.C. Comparação de métodos químicos para avaliar a disponibilidade do manganês em solos. Revista Brasileira de Ciência do Solo, v.18, p.81-90, 1994.

ABREU, C.A.; LOPES, A.S.; RAIJ, B. van Análise de micronutrientes em solos brasileiros: situação atual e perspectiva. In: CONGRESSO BRASILEIRO DE CIÊNCIA DO SOLO, 28, Rio de Janeiro, 1997. Anais. Rio de Janeiro, 1997 (CD-Rom)

ABREU, C.A.; RAIJ, B.van; TANAKA, R.T. Comportamento de cultivares de soja em solo deficiente em manganês. In: REUNIÃO BRASILEIRA DE FERTILIDADE DO SOLO E NUTRIÇÃO DE PLANTAS, 21, Petrolina, 1994. Anais. Petrolina: EMBRAPA-CNPATSA / SBCS, 1994. p.235-236.

ABREU, C.A.; RAIJ, B.van; TANAKA, R.T. Fontes de manganês para soja e seus efeitos na análise de solo. Revista Brasileira de Ciência do Solo, v.20, p.91-97, 1996.

AGUIAR, P.A.A. Efeito do tamanho da semente na germinação e vigor da soja (Glycine max L. Merrill). In: SEMINÁRIO NACIONAL DE PESQUISA DE SOJA, 1, 1978, Londrina. Anais, Londrina: EMBRAPA. Centro Nacional de Pesquisa de Soja, 1979, v.2, p.325-332. 
ALLEY, M.M.; RICH, C.I.; HAWKINS, G.W.; MARTENS, D.C. Correction of Mn deficiency of soybeans. Agronomy Journal, v.70, p.35-38, 1978.

AMBROSANO, E.J.; TANAKA, R.T.; MASCARENHAS, H.A.A.; RAIJ, B. van; QUAGGIO, J.A.; CANTARELLA, $H$. Leguminosas e oleaginosas. In: RAIJ, B. van; CANTARELLA, H.; QUAGGIO, J.A.; FURLANI, A.M.C. (Ed.). Recomendações de adubação e calagem para o estado de São Paulo. Campinas: Instituto Agronômico \& Fundação IAC, 1996. p.187-203.

ARANTES, N.E.; KIIHL, R.A.S.; ALMEIDA, L.A. Cultivar de soja MG/BR-48 (GARIMPO RCH). In: CONGRESSO BRASILEIRO DE SOJA, 1, Londrina, 1999. Anais. Londrina: Embrapa Soja, 1999. p.502.

BARNES, J.D.; BALGUER, L.; MANRIQUE, E.; ELVIRA, S.; DAVISON, A.W.A. A reapppraisal of the use of DMSO for the extraction and determination of chlorophylls $a$ and $b$ in lichens and higher plants. Environment Experimental Botany, v.32, p.85-100, 1992.

BARBOSA, M.Z.; FERREIRA, C.R.R.P.T.; FREITAS, S.M. Sazonalidade dos preços de exportação do complexo soja do Brasil. In: CONGRESSO BRASILEIRO DE SOJA, 1, Londrina, 1999. Anais. Londrina: Embrapa Soja, 1999. p.439.

BATAGLIA, O.C.; MASCARENHAS, H.A.A. Absorção de nutrientes pela soja. Instituto Agronômico de Campinas, 1977. 36p. (Boletim Técnico, 41).

BERGER, K.C.; TRUOG, E. Boron determination in soils and plants using the quinazizarin reaction. Industrial and Engineering Chemistry, v.11, n.3, p.540-545, 1939. 
BORKERT, C.M. Manganês. In: SIMPÓSIO SOBRE MICRONUTRIENTE NA AGRICULTURA, 1, Jaboticabal, 1988. Micronutrientes na Agricultura: anais. Piracicaba: POTAFOS/CNPq, 1991. p.173-190.

BRASIL. Ministério da Agricultura e Reforma Agrária. Regras para Análise de Sementes. Brasília: SNAD/DNDVICLAV, 1992. 365p.

BRASIL. Ministério da Agricultura. Padrões estaduais de sementes. Brasília: EMBRAPA/SNSB, 1993. 47p.

CÂMARA, G.M.S. Fenologia da soja. In: _-(Ed.). Soja. Tecnologia da Produção. Piracicaba: Publique, 1998. p.26-39.

CAMARGO, O.A. Reações e interações de micronutrientes no solo. In: SIMPÓSIO SOBRE MICRONUTRIENTE NA AGRICULTURA, 1, Jaboticabal, 1988. Micronutrientes na Agricultura: anais. Piracicaba: POTAFOS/CNPq, 1991. p.243-272.

CARVALHO, N.M.; NAKAGAWA, J. Sementes: ciência, tecnologia e produção. Campinas: Fundação Cargill, 1988. 424p.

DANTAS, J.P. Boro. In: SIMPÓSIO SOBRE MICRONUTRIENTE NA AGRICULTURA, 1, Jaboticabal, 1988. Micronutrientes na Agricultura: anais. Piracicaba: POTAFOS/CNPq, 1991. p.113-130.

DECHEN, A.R.; HAAG, H.P.; CARMELLO, Q.A.C. Diagnose visual. In: SIMPÓSIO SOBRE MICRONUTRIENTE NA AGRICULTURA, 1 , Jaboticabal, 1988. Micronutrientes na Agricultura: anais. Piracicaba: POTAFOS/CNPq, 1991b. p.273-288. 
DECHEN, A.R.; HAAG, H.P.; CARMELLO, Q.A.C. Funções dos micronutrientes nas plantas. In: SIMPÓSIO SOBRE MICRONUTRIENTE NA AGRICULTURA, 1, Jaboticabal, 1988. Micronutrientes na Agricultura: anais. Piracicaba: POTAFOS/CNPq, 1991a. p.65-97.

DELOUCHE, J.C. Environmental effects on seed development and seed quality. HortScience, v.15, n.6, p.775-780, 1980.

EMBRAPA. Levantamento de reconhecimento de média intensidade dos solos e avaliação da aptidão agrícola das terras do triângulo mineiro. Rio de Janeiro, 1982. 526p. (Boletim de Pesquisa, 1).

EMBRAPA. Recomendações técnicas para a cultura da soja na região Central do Brasil, 1996/97. Londrina, 1996. 164p. (Embrapa-Soja. Documentos, 96).

EMBRAPA. Recomendações técnicas para a cultura da soja na região Central do Brasil, 1997/98. Londrina, 1997. 171p. (Embrapa-Soja. Documentos, 106).

EMBRAPA. Recomendações técnicas para a cultura da soja na regiăo Central do Brasil, 1998/99. Londrina, 1998. 182p. (Embrapa-CNPSo. Documentos, 120).

FEHR, W.R.; CAVINESS, C.E. Stages of soybean development. Ames: lowa State University of Science and Technology, 1977. 11p.

FEHR, W.R.; PROBST, A.H. Effect of seed source on soybean strain performance for two sucessive generations. Crop Science, v.11, p.865-867, 1971. 
FERREIRA, C.R.R.P.T.; FREITAS, S.M.; BARBOSA, M.Z. Adubação da soja no Brasil: Aspectos econômicos. In: CONGRESSO BRASILEIRO DE SOJA, 1, Londrina, 1999. Anais. Londrina: Embrapa Soja, 1999. p.439

FONTES, L.A.N.; OHLROGGE, A.J. Influence of seed size and population on yield and other characteristics of soybean [Glycine $\max$ (L.) Merr.]. Agronomy Journal, v.64. p. 833-836, 1972.

FONTES, L.G.; ALMEIDA, F.J.; SEDIYAMA, C.S. Conteúdo de óleo e proteina bruta nos grãos de algumas linhagens e variedades de soja (Glycine max L. Merrill). Revista Ceres, v.21, n.118, p.500-505, 1974.

FONTES, R.L.F. Pesquisa com micronutrientes em solos e plantas: difusão dos resultados no Brasil. In: CONGRESSO BRASILEIRO DE CIÊNCIA DO SOLO, 28, Rio de Janeiro, 1997. Anais. Rio de Janeiro, 1997 (CD-Rom).

FRANCO, A.A.; DÖBEREINER, J. Toxidez de manganês de um solo ácido na simbiose soja Rhizobium. Pesquisa Agropecuária Brasileira, v.6, p.57-66, 1971.

GALRÃO, E.Z. Micronutrientes e cobalto no rendimento da soja em solo de cerrado. Revista Brasileira de Ciência do Solo, v.15, p.117-120, 1991.

GHAZALI, N.J.; COX, F.R. Effect of temperature on soybean growth and manganese accumulation. Agronomy Journal, v.60, p.521-524, 1968.

GODO, G.H.; REISENAUER, H.M. Plant effects on soil manganese availabilility. Soil Science Society America Journal, v.44, p.993-995, 1980. 
HANWAY, J.J.; WEBER, C.R. Accumulation of N, P and K by soybean (Glycine $\max ($ L.) Merrill) plants. Agronomy Journal, v.63, p.406-408, 1971.

HARRIS, H.B.; PARKER, M.B.; JOHNSON, B.J. Influence of molybdenum content of soybean seed and other factors associated with seed source on progeny response to applied molybdenum. Agronomy Journal, v. 57, n. 2 , p. 397-399, 1965.

HEENAN, D.P.; CAMPBELL, L.C. Growth, yield components and seed composition of two soybean cultivars as affected by manganese supply. Australian Joumal of Agricultural Research, v.31, p.471-476, 1980.

HILL, L.; BENDER, K.; BODE, G.; BEACHY, K.; DUERINGER, J. Quality choices in international soybean markets. Agribusiness, v.12, n.3, p.231246, 1996.

HOMANN, P.E. Studies on the manganese of the chloroplast. Plant Physiology, v. 42, p.997-1007, 1967.

KABATA- PENDIAS, A.J.; PENDIAS, $H$. Trace elements in soils and plants. Boca Raton: CRC Press, 1985. 315p.

LAZARINI, E. Avaliação das caracteristicas agronômicas e análises nutricionais de genótipos de soja semeados em diferentes épocas em Jaboticabal - SP. Jaboticabal: FCAVJ/UNESP, 1995. 197p.(Doutorado em Agronomia).

LEITE, M.C. Novas fronteiras de produção e o intermodal de transporte. In: CONGRESSO BRASILEIRO DE SOJA, 1, Londrina, 1999. Anais. Londrina: Embrapa Soja, 1999. p.51-58. 
LINDSAY, W.L. Chemical equilibrium in soils. New York: John Wiley \& Sons, 1979. 449p.

LINDSAY, W.L.; NORVELL, W.A. Development of a DTPA soil test for zinc, iron, manganese and cooper. Soil Science Society of America Journal, v. 42, n. 3, p. $421-428,1978$.

LOEFFLER, T.M.; TEKRONY, D.M.; EGLI, D.B. The bulk conductivity test as an indicator of soybean seed quality. Journal Seed of Technology, v.12, n.1, p.37-53, 1988.

LOPES, A.S. Micronutrientes: Filosofias de aplicação, fontes, eficiência agronômica e preparo de fertilizantes. In: SIMPÓSIO SOBRE MICRONUTRIENTE NA AGRICULTURA, 1, Jaboticabal, 1988. Micronutrientes na Agricultura: anais. Piracicaba: POTAFOS/CNPq, 1991. p.357-390.

LOPES, A.S., GUILHERME, L.R.G. Solos sob cerrado: manejo da fertilidade para a produção agropecuária. São Paulo: ANDA, 1994. 62p. (Boletim técnico, 5)

MALAVOLTA, E.; BOARETTO, A.E.; PAULINO, V.T. Micronutriente - Uma visão geral. In: SIMPÓSIO SOBRE MICRONUTRIENTE NA AGRICULTURA, 1, Jaboticabal, 1988. Micronutrientes na Agricultura: anais. Piracicaba: POTAFOS/CNPq, 1991. p.1-33.

MALAVOLTA, E. et al. Exigências minerais comparadas de dois cultivares de soja (Glycine max (L.) Merrill): Santa Rosa e UFV-1. Anais da Esalq, Piracicaba, v.37, p.463-471, 1980. 
MALAVOLTA, E.; VITTI, G.C.; OLIVEIRA, S.A. de. Avaliação do estado nutricional das plantas: princípios e aplicações. Piracicaba: Associação Brasileira para Pesquisa de Potassa e Fosfato, 1997. 319p.

MALAVOLTA, E. Manual de química agrícola: Nutrição de plantas e fertilidade do solo. São Paulo, Editora Agronômica Ceres, 1976. 528p.

MALAVOLTA, E. Elementos de nutrição mineral de plantas. São Paulo: Agronômica Ceres, 1980. 251p.

MALAVOLTA, E. Manual de química agrícola: Adubos e adubação. São Paulo: Agronômica Ceres, 1981. 596p.

MALAVOLTA, E.; KLIEMANN, H.J. Desordens nutricionais no cerrado. Piracicaba: POTAFOS, 1985. 136p.

MANDARINO, J.M. et al. Teor de óleo e proteína em sementes de soja oriundas de três regiões edafoclimáticas distintas no estado do Paraná. In: CONGRESSO BRASILEIRO DE SEMENTES, 8, 1993, Foz do Iguaçu. Resumos. Londrina: EMBRAPA-CNPSo. Informativo ABRATES, v.3, p.22, 1993.

MANN, E.N.; CARVALHO, J.G.; REZENDE, P.M.; BOTREL, E.P.; LEDO, C.A.S. Resposta da cultura da soja à aplicação de micronutrientes em um latossolo vermelho amarelo do sul de Minas Gerais. In: CONGRESSO BRASILEIRO DE SOJA, 1, Londrina, 1999. Anais. Londrina: Embrapa Soja, 1999a. p.348.

MANN, E.N.; REZENDE, P.M.; CARVALHO, J.G.; CORTE, E.; LEDO, C.A.S. Aplicação foliar de manganês na cultura da soja. In: CONGRESSO 
BRASILEIRO DE SOJA, 1, Londrina, 1999. Anais. Londrina: Embrapa Soja, 1999b. p.349.

MARCOS FILHO, J. Teste de envelhecimento acelerado. In: VIEIRA, R.D., CARVALHO, N.M. (Ed.). Testes de vigor em sementes. Jaboticabal: FUNEP, 1994. p.133-149.

MARCOS FILHO, J. Teste de envelhecimento acelerado. In: KRZYZANOWSKI, F.C.; VIEIRA, R.D.; FRANÇA NETO, J.B. (Ed.). Vigor de sementes: conceitos e testes. Londrina: ABRATES, 1999, cap. 3, p.1-24.

MARCOS FILHO, J.; CÍCERO, S.M.; SILVA, W.R. Avaliação da qualidade das sementes. Piracicaba: FEALQ, 1987. 230p.

MARINHO, M.L. Respostas das culturas aos micronutrientes ferro, manganês e cobre. In: BORKERT, C.M.; LANTMANN, S.F. (Ed.). Enxofre e micronutrientes na agricultura brasileira. Londrina: EMBRAPA/IAPAR/SBCS, 1988. p. 239-264.

MASCARENHAS, H.A.A.; MIRANDA, M.A.C.; TANAKA, R.T.; FALIVENE, S.M.P.; DECHEN, A.R. Comportamento de cultivares precoces de soja em soluçāo nutritiva contendo diferentes níveis de manganês. Pesquisa Agropecuária Brasileira, v.25, n.4, p.609-615, 1990a.

MASCARENHAS, H.A.A.; TEIXEIRA, J.P.F.; NAGAI, V.; TANAKA, R.T.; GALLO, P.B.; PEREIRA, J.C.V.N.A. A calagem nos teores de óleo e proteína em soja. Bragantia, v.49, p.171-182, 1990b.

MASCARENHAS, H.A.A.; TANAKA, R.T.; GALLO, P.B.; PEREIRA, J.C.V.N.A.; AMBROSANO, G.M.B.; CARMELLO, Q.A.C. Efeito da calagem sobre a 
produtividade de grãos, óleo e proteína em cultivares precoces de soja. Scientia Agricola, v.53, n.1, p.164-171, 1996.

MASCARENHAS, H.A.A.; NEPTUNE, A.M.L.; MURAOKA, T.; BULISANI, E.A. HIROCE, R. Absorção de nutrientes por cultivares de soja (Glycine max (L.) Merrill). Revista Brasileira de Ciência do Solo, v.4, p.92-96, 1980.

MATTHEWS, S. Evaluation of techniques for germination and vigor studies. Seed Science and Technology, v.9, n.2, p.543-551, 1981.

McDOUGALL, G.J.; MORRISON, I.M.; STEWART, D.; HILLMAN, J.R. Plant cell wallsas dietary fibre: range, structure, processing and function. Journal Science Food Agricultural, v.70, n.2, p.133-150, 1996.

MEDINA, P.F. Produção de sementes de cultivares precoces de soja, em diferentes épocas e locais do Estado de São Paulo. Piracicaba: ESALQ/USP, 1994. 173p. (Doutorado em Agronomia).

MENGEL, D.B.; SEGARS, W.; REHM, G.W. Soil fertility and liming. In. WILCOX, J.R. Soybeans: improvement, production and uses. Madison: American Society of Agronomy, 1987. p.461-496.

MENGEL, K.; KIRKBY, E.A. Principles of plant nutrition. Switzerland: International Potash Institute, 1987. 687p.

MIYAZAWA, M.; PAVAN, M.A.; MARTIN NETO, L. Provável mecanismo de liberação do manganês no solo. Pesquisa Agropecuária Brasileira, v.28, n.6, p.725-731, 1993. 
MOREIRA, M.A. Programa de melhoramento genético da qualidade de óleo e proteína da soja desenvolvido na UFV. In: CONGRESSO BRASILEIRO DE SOJA, 1, Londrina, 1999. Anais. Londrina: Embrapa Soja, 1999. p.99-104.

NOVAIS, R.F.; NEVES, J.C.L.; BARROS, N.F.; SEDIYAMA, T. Deficiência de manganês em plantas de soja cultivadas em solos de cerrados. Revista Brasileira de Ciência do Solo, v.13, p.199-204, 1989.

OHKI, K.; BOWELL, F.C.; PARKER, M.B.; SHUMAN, L.M.; WILSON, D.O. Critical manganese deficiency level of soybean related to leaf position. Agronomy Journal, v.71, p.233-234, 1979.

OHKI, K.; BOWELL, F.C.; PARKER, M.B.; SHUMAN, L.M.; WILSON, D.O. Foliar manganese application to soybean. Communications in Soil Science and Plant Analysis, v. 18, p.243-253, 1987.

OHKI, K.; WILSON, D.O.; BOWELL, F.C.; PARKER, M.B.; SHUMAN, L.M. Mn concentration in soybean leaf related to bean yields. Agronomy Journal, v.69, p.597-600, 1977.

OLIVEIRA, A.F.F.; ATHAYDE, M.L.F.; SADER, R. Avaliação da qualidade da soja produzida em área de reforma de canavial. Pesquisa Agropecuária Brasileira, v.26, p.613-621,1991.

OLIVEIRA, J.A.; CABRAL, C.P.; MALAVOLTA, E. Resposta da soja ao efeito residual do manganês aplicado em um solo de cerrado. In: CONGRESSO BRASILEIRO DE SOJA, 1, Londrina, 1999. Anais. Londrina: Embrapa Soja, 1999. p.350. 
OLIVEIRA, M.W.; SEDIYAMA, C.S.; NOVAIS, R.F.; SEDIYAMA, T. Crescimento de cultivares de soja em condiçōes de baixa disponibilidade de manganês no solo. II. Concentração e alocação do manganês. Revista Ceres, v.44, n.251, p.43-52, 1997.

PANOBIANCO, M.; VIEIRA, R.D.; KRZYZANOWSKI, F.C.; FRANÇA-NETO, J.B. Electrical conductivity of soybean sead and correlation with seed coat lignine content. Seed Science and Technology, v.27, p.945-949, 1999.

PARKER, M.B.; BOSWELL, F.C.; OHKI, K.; SHUMAN, L.M.; WILSON, D.O. Manganese effects on yield and nutrient concentration in leaves and seed of soybean cultivars. Agronomy Journal, v.73, p.643-646, 1981.

PARKER, M.B.; HARRIS, H.B.; MORRIS, H.D.; PERKINS, H.F. Manganese toxicity of soybeans as related to soil and fertility treatments. Agronomy Journal, v.61, p.515-518, 1969.

QUAGGIO, J.A.; MASCARENHAS, H.A.A.; BATAGLIA, O.C. Resposta da soja à aplicação de doses crescentes de calcário em Latossolo Roxo distrófico de cerrado. II. Efeito Residual. Revista Brasileira de Ciência do Solo, v.6, p.113-118, 1982.

QUAGGIO, J.A.; SILVA, N.M.; BERTON, R.S. Culturas oleaginosas. In: SIMPÓSIO SOBRE MICRONUTRIENTE NA AGRICULTURA, 1 , Jaboticabal, 1988. Micronutrientes na Agricultura: anais. Piracicaba: POTAFOS/CNPq, 1991. p.445-484.

RAIJ, B.van; DIEST, A. van Utilization of phosphate from different sources by six plant species. Plant and Soil, v.51, n.4, p.577-589, 1979. 
RAIJ, B.van; CANTARELLA, H.; QUAGGIO, J.A.; FURLANI, M.C. Boletim Técnico 100 - Recomendações de adubação e calagem para o estado de São Paulo. Campinas: IAC, 1997. 285p.

RAIJ, B.van; QUAGGIO, J.A. Métodos de análise de solo para fins de fertilidade. Campinas: Instituto Agronômico, 1983. 31p. (Boletim Técnico, 81).

RAMOS, W.J.; MASCARENHAS, H.A.A.; BATAGLIA, O.C; IGUE, T; TANAKA, R.T. Acúmulo de massa seca e teores de elementos químicos em três cultivares de soja em função da correção da acidez do solo de Itararé (SP). Bragantia, v.48, p.223-232, 1989.

RANDALL, G.W.; SCHULTE, E.E.; COREY, R.B. Effect of soil and foliar applied manganese on the micronutrient content and yield of soybeans. Agronomy Journal, v.67, p.502-507, 1975a.

RANDALL, G.W.; SCHULTE, E.E.; COREY, R.B. Soil Mn availability to soybeans as affected by mono and diammonium phosphate. Agronomy Journal, v.67, p.705-709, 1975b.

REDDY, M.R.; TUCKER, M.R.; DUNN, S.J. Effect of manganese on concentrations of $\mathrm{Zn}, \mathrm{Fe}, \mathrm{Cu}$ and $\mathrm{B}$ in different soybean genotypes. Plant and Soil, v. 97, p.57-62, 1987.

REDFERM, J.W. Resposta da cultura da soja (Glycine max (L.) Merrill) cv. IAC6, a diferentes doses e fontes de adubos fosfatados. Jaboticabal, FCAVIUNESP, 1984. 25p. (Trabalho de graduação). 
RITCHIE, S.W.; HANWAY, J.J.; THOMPSON, H.E.; BENSON, G.O. Como a planta de soja se desenvolve. Trad. G.M.S. Câmara. Piracicaba: POTAFOS, 1997. 21p.

RITCHEY, Y.D.; URBEN FILHO, G.; SPEHAR, C.R. Deficiência de manganês induzida por doses excessivas de calcário em um Latossolo VermelhoEscuro, anteriormente sob vegetação de cerrado. In: SEMINÁRIO NACIONAL DE PESQUISA DA SOJA, 2, 1981, Brasilia. Anais. Brasília: EMBRAPA-CNPSo, 1981. p.541-544.

ROSOLEM, C.A.; BESSA, M.A.; AMARAL, P.G. do; PEREIRA, H.F.M. Manganês no solo, sua avaliação e toxidez de manganês em soja. Pesquisa Agropecuária Brasileira, v.27, n.2, p.277-285, 1992.

ROSOLEM, C.A.; NAKAGAWA, J. Deficiência de Mn em soja induzida por adubação potássica e calagem. In: SEMINÁRIO NACIONAL DE PESQUISA DE SOJA, 4, Porto Alegre. Programa e Resumos, Porto Alegre: EMBRAPAIPAGRO, 1986. p. 53.

SÁ, M.E. Importância da adubação na qualidade de semente. In: SÁ, M.E.; BUZZETI, S. (Ed.). Importância da adubação na qualidade dos produtos agrícolas. São Paulo: Ícone, 1994. p.65-98.

SANTOS, O.S. Micronutrientes na cultura da soja. Informações Agronômicas, n.85, p.1-8, 1999.

SANTOS, O.S.; ESTEFANEL, V.; CAMARGO, R.P. Exportação de nutrientes por cultivar de soja. Trigo e Soja, n.83, p.7-10, 1986. 
SCOTT, W.O.; ALDRICH, S.R. Production moderna de la soja. Buenos Aires: Hemifério Sur, 1975. 192p.

SFREDO, G.J. ; PANIZZI, M.C.C. Importância da adubação e da nutrição na qualidade da soja. Londrina: EMBRAPA-CNPSo, 1990. 57p. (Documentos, 40).

SILVA, A.R.; ANDRADE, J.M.V.; PERES, J.R.R. Efeito residual de micronutrientes no teor foliar e na produção de soja no cerrado. Pesquisa Agropecuária Brasileira, v.21, n.6, p.597-613, 1986.

SMITH, J.J.; CAMPER, H.M. Effect of seed size on soybean performance. Agronomy Abstract. n.67, p.22-27, 1970.

SOUSA, D.M.G.; MIRANDA, L.N.; LOBATO, E; CASTRO, L.H.R. Métodos para determinação da necessidade de calagem em solos dos cerrados. Revista Brasileira de Ciência do Solo, v.13, n.2, p.193-198, 1989.

SOUZA, L.H. Efeito do pH da rizosfera de plantas de soja inoculadas com Bradyrhizobium japonicum na absorção de boro, cobre, ferro, manganês e zinco. Viçosa: UFV, 1996. 64p. (Doutorado em Fitotecnia).

TANAKA, R.T.; MASCARENHAS, H.A.A. Teores e produtividade de óleo e proteína de soja devido à aplicação de calcário e de gesso agrícola. In: CONGRESSO E EXPOSIÇÃO LATINO AMERICANO SOBRE PROCESSAMENTO DE ÓleO E GORDURA. Campinas, 1995. Anais. Campinas: UNICAMP, 1995. p.207-210.

TANAKA, R.T.; MASCARENHAS, H.A.A. Soja: nutrição, corrreção do solo e adubação. Campinas: Fundação Cargill, 1992. 60p. (Boletim Técnico, 7). 
TANAKA, R.T.; MASCARENHAS, H.A.A.; BORKERT, C.M. Nutrição mineral da soja. In: ARANTES, M.E.; SOUZA, P.I.M. (Ed.). Cultura da soja nos cerrados. Piracicaba: POTAFOS, 1993. p.105-135.

TANAKA, R.T.; MASCARENHAS, H.A.A.; BULISANI, E.A. Deficiência de manganês em soja induzida por excesso de calcário. Pesquisa Agropecuária Brasileira, v.27, n.2, p.247-250, 1992a.

TANAKA, R.T.; MASCARENHAS, H.A.A.; DIAS, O.S.; CAMPIDELLI, C.; BULISANI, E.A. Cultivo da soja após incorporação de adubo verde e orgânico. Pesquisa Agropecuária Brasileira, v.27, p.1477-1483, 1992b

TANAKA, R.T.; MASCARENHAS, H.A.A.; MIRANDA, M.A.C.; DEGASPARI, N.; CARMELO, Q.A.C. Deficiência nutricional em soja cultivada em solo de cerrado devido à incorporação superficial de calcário. O Agronômico, v.41, n.3, p.231-241, 1989.

TEIXEIRA, J.P.F.; MASCARENHAS, H.A.A.; BATAGLIA, O.C. Efeito de cultivares, tipos de solos e práticas culturais sobre a composição química de sementes de soja (Glycine max L. Merrill). In: SEMINÁRIO NACIONAL DE PESQUISA DE SOJA, 1, 1978, Londrina. Anais. Londrina: EMBRAPACNPSo, 1979, p.11-16.

TISDALE, S.L.; NELSON, L.W.; BEATON, J.D. Soil fertility and fertilizers. In: Micronutrients and other beneficial elements in soils and fertilizers. New York:MacMillan, 1985. p.350-413.

TURKIEWICZ, L. Efeito da calagem e adubação fosfatada sobre a germinação e o vigor de sementes de soja (Glycine max L. Merrill) Piracicaba: ESALQ/USP, 1976, 85p. (Mestrado em Agronomia). 
VELLO, N.A. Programa de melhoramento genético da soja para produtividade de óleo desenvolvido na ESALQ/USP. In: CONGRESSO BRASILEIRO DE SOJA, 1, Londrina, 1999. Anais. Londrina: Embrapa Soja, 1999. p.105-111.

VERNETTI, F.J. Bases genéticas e fisiológicas da produção e nutrição. In: Soja, genética e melhoramento. Campinas: Fundação Cargill, 1983. p.877-990.

VIEIRA, R.D. Teste de condutividade elétrica. In: VIEIRA, R.D., CARVALHO, N.M. (Ed.). Testes de vigor em sementes. Jaboticabal: FUNEP, 1994. p.103-132.

VIEIRA, R.D.; KRZYZANOWSKI, F.C. Teste de condutividade elétrica. In: KRZYZANOWSKI, F.C.; VIEIRA, R.D.; FRANÇA NETO, J.B. (Ed.). Vigor de sementes: conceitos e testes. Londrina: ABRATES, 1999, cap. 4, p.1-26.

VITTI, G.C. Avaliação e interpretação do enxofre no solo e na planta. Jaboticabal: FUNEP, 1989. 37p.

VITTI, G.C.; LUZ, P.H.C. Manejo químico do solo para alta produtividade da soja. In: CÂMARA, G.M.S. (Ed.). Soja: Tecnologia da produção. Piracicaba: Publique, 1998. p.84-112.

VOLKWEISS, S.J. Fontes e métodos de aplicação. In: SIMPÓSIO SOBRE MICRONUTRIENTE NA AGRICULTURA, 1, Jaboticabal, 1988. Micronutrientes na Agricultura: anais. Piracicaba: POTAFOS/CNPq, 1991. p.391-412. 
WILLIAMS, D.E.; VLAMIS, J. The effect of silicon on yield and manganese 54 uptake and distribution in the leaves of barley plants grown in culture solutions. Plant Physiology, v.32, p.404-409, 1957.

WILSON, D.O.; BOSWELL, F.C.; OHKI, K.; PARKER, M.B.; SHUMAN, L.M.; JELLUM, M.D. Changes is soybean seed oil and protein as influenced by manganese nutrition. Crop Science, v.22, p.948-952, 1982.

ZITO, R.K.; SOUZA, J.A.; ARANTES, N. E.; FRONZA, V.; GUIDOLIN, J.A.; CRUVINEL, W.F. Aplicação foliar de micronutrientes na soja, em área infestada com Heterodera glycines, raça 3. In: CONGRESSO BRASILEIRO DE SOJA, 1, Londrina, 1999. Anais. Londrina: Embrapa Soja, 1999. p.353.

ZONTA, E.P.; MACHADO, A.D. Sistemas de análise estatística para microcomputadores - SANEST. Pelotas, UFPel, 1984. 109p. 